\title{
Alaska's Mineral Industry 2017
}

Special Report 73

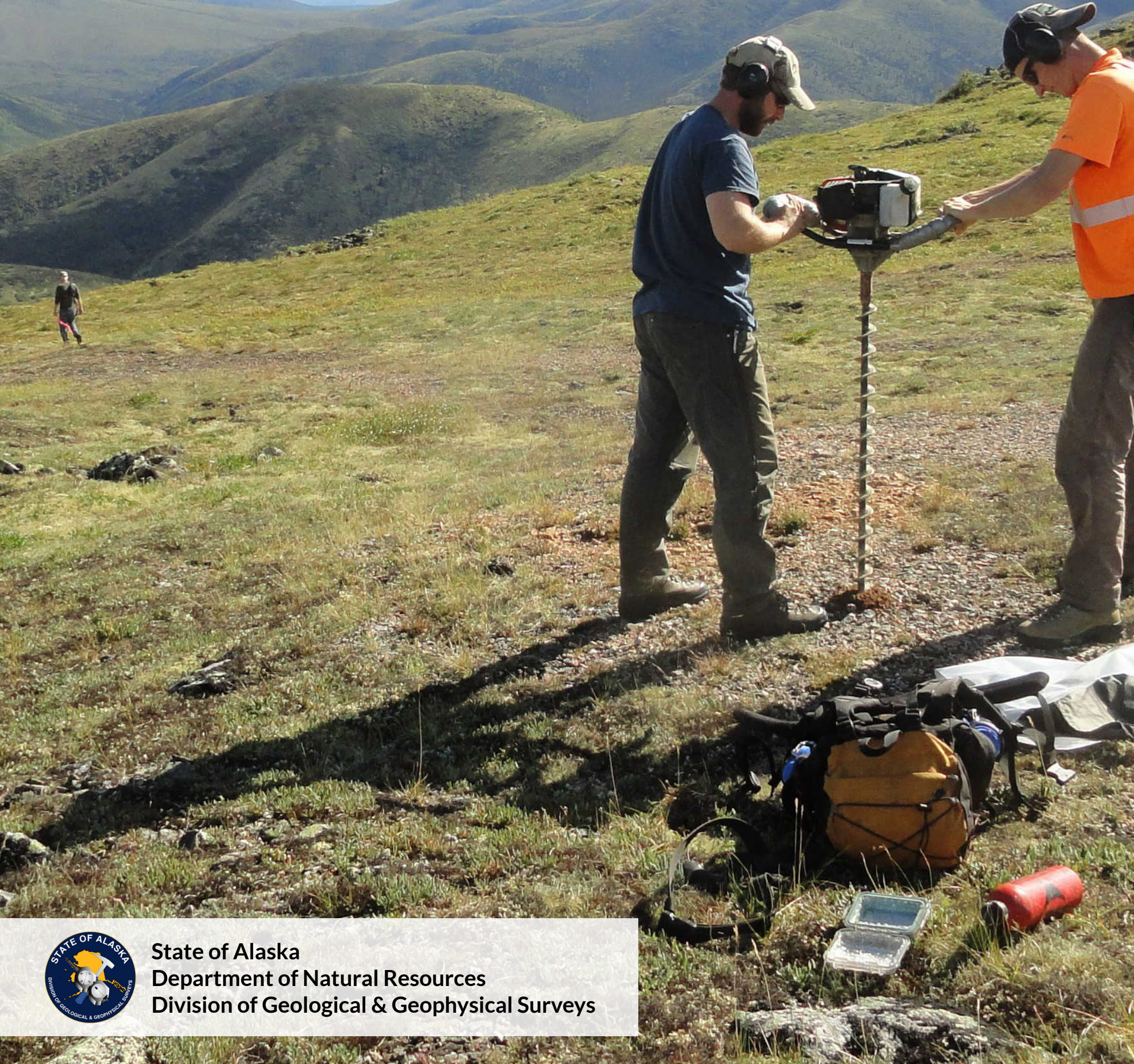

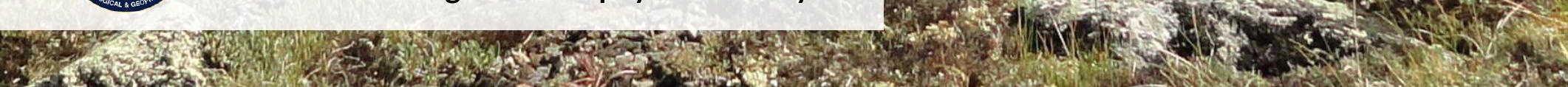


STATE OF ALASKA

Bill Walker, Governor

\section{DEPARTMENT OF NATURAL RESOURCES}

Andrew T. Mack, Commissioner

\section{DIVISION OF GEOLOGICAL \& GEOPHYSICAL SURVEYS}

Steve Masterman, State Geologist and Director

Publications produced by the Division of Geological \&

Geophysical Surveys (DGGS) are available for free download

from the DGGS website (dggs.alaska.gov). Publications on

hard-copy or digital media can be examined or purchased in the

Fairbanks office:

Alaska Division of Geological \& Geophysical Surveys

3354 College Rd., Fairbanks, Alaska 99709-3707

Phone: (907) 451-5010 Fax (907) 451-5050

dggspubs@alaska.gov | dggs.alaska.gov

DGGS publications are also available at:

Alaska State Library,

Historical Collections \& Talking Book Center

395 Whittier Street

Juneau, Alaska 99811

Alaska Resource Library and Information Services (ARLIS)

3150 C Street, Suite 100

Anchorage, Alaska 99503

\section{Suggested citation:}

Athey, J.E., and Werdon, M.B., 2018, Alaska's mineral industry 2017: Alaska

Division of Geological \& Geophysical Surveys Special Report 73.

http://doi.org/10.14509/30075
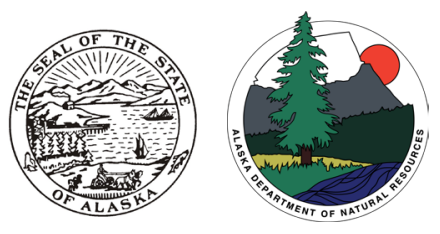

This publication, released by the Division of Geological \& Geophysical Surveys (DGGS), was produced and printed in Fairbanks, Alaska by DGGS, at a cost of $\$ 3.00$ per copy. Authority to print this and other publications is based on Alaska Statute 41.08.020, which charges DGGS to “...determine the potential of Alaskan land for production of metals, minerals, fuels, and geothermal resources; the location and supplies of groundwater and construction materials; the potential geologic hazards to buildings, roads, bridges, and other installations and structures; and... construct such other surveys and investigations as will advance knowledge of the geology of Alaska." Statue 41.08.030 adds, "The state geologist shall print and publish an annual report and such other special and topical reports and maps as may be desirable for the benefit of the state..." In addition, Alaska Statue 27.05.050-060 states, "The department shall conduct a continuing survey of the mineral resources and mining operations of the state and shall disseminate information regarding them to assist prospectors and miners, safeguard the lives and health of miners, protect investors in the mining industry, and foster and promote the best interests of the mining, mineral, and related industries of the state... The department shall make an annual report to the governor on all essential matters with regard to mining in the state...” 


\section{Alaska's Mineral Industry 2017}

Jennifer E. Athey ${ }^{1}$ and Melanie B. Werdon ${ }^{1}$

The State of Alaska Division of Geological \& Geophysical Surveys complies with title II of the Americans with Disabilities Act of 1990. This publication is available in alternative communication formats upon request. Please contact DGGS (phone 907-451-5010; fax 907451-5050; email dggspubs@alaska.gov) to make any necessary arrangements.

Mention of any company or brand name does not constitute endorsement by any branch or employee of the State of Alaska.

Cover. 2017 power auger soil survey at the Trout target, near Quail Creek, in interior Alaska, one of three gold properties comprising the Elephant Mountain project. Photo courtesy of Robert T. Boyd, Endurance Gold Corporation. 



\section{Executive Summary}

This summary of the status of Alaska's mineral industry for 2017 is the $37^{\text {th }}$ such annual report produced by the Department of Natural Resources, Division of Geological \& Geophysical Surveys and partner agencies. Published for more than one-third of a century, the annual report endeavors to provide a consistent and factual snapshot of mineral industry activity in Alaska. It also serves as the authoritative, historical record of mining in the State.

\section{Exploration Expenditures}

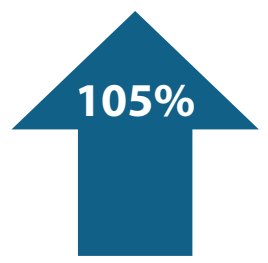

Development Expenditures

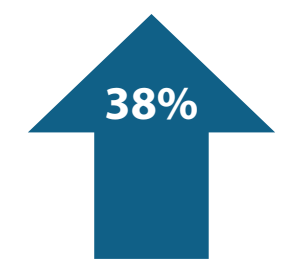

Estimated Revenue to Industry

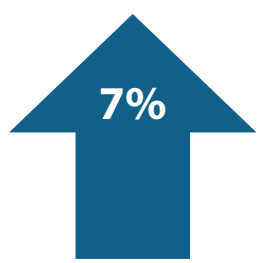

The reported value of Alaska's mineral industry in 2017 totaled $\$ 3.15$ billion, an increase of almost 12 percent from 2016. The total value for 2017 is a composite of the year's expenditures on exploration and development, plus the revenue to the operators from the commodities produced.

Exploration and development expenditures and production values, along with other major indicators of the health of Alaska's mining industry, rebounded in 2017 to values not seen for several years.

Zinc was the top metal produced in 2017, accounting for more than half of Alaska's total metal production by value. Gold followed at 33 percent, along with lead at 8.8 percent and silver at 7.7 percent. However, quantities produced declined for all metals.

Development expenditures in Alaska rose 38 percent in 2017 , to $\$ 299.5$ million. Development expenditures at Alaska's major metal mines accounted for 89 percent of total development expenditures.

Mineral exploration expenditures rose dramatically in 2017 to $\$ \mathbf{1 2 0 . 8}$ million, more than doubling expenditures from the 2016 level of $\$ 58.9$ million. The major mines spent 29 percent of the State's exploration budget, down significantly from 49 percent in 2016, signaling increased activity on undeveloped prospects and deposits in the State.

Teck Alaska Inc.'s drilling at Aktigiruq suggests they have discovered another worldclass, sediment-hosted zinc deposit in the Red Dog district.

Mining claims and prospecting sites covered almost three million acres of Alaska in 2017, with 6,259 active Federal and 34,249 active State mining claims. While the total area of the State held by mining claims increased by 16 percent, the area of new claims staked in 2017 increased by more than 230 percent.

Mineral industry employment in 2017 is estimated at 3,392 full-time-equivalent jobs, an overall increase of about 160 jobs ( 5 percent) from 2016. The number of exploration jobs increased by almost 59 percent to 254 jobs in 2017, and combined production and development jobs saw a 2 percent gain as 66 new jobs were reported.

Estimated revenues to the State of Alaska and municipalities from mineral-industry-specific fees, rents, sales, royalties, and taxes amounted to more than $\$ 120.6$ million in 2017, an increase of 73 percent from 2016. 


\section{Contents}

INTRODUCTION ........................................................................................................................................................................................

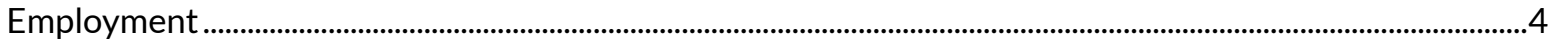

Government Revenues from Alaska's Mineral Industry ……..............................................................................6

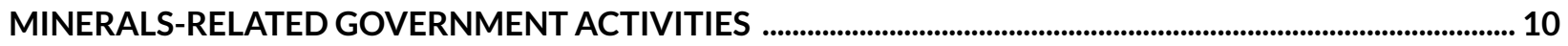

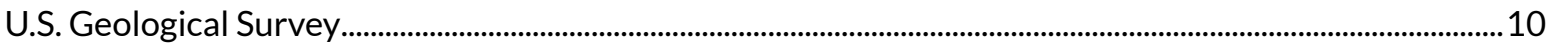

U.S. Bureau of Land Management ...................................................................................................................... 10

Division of Mining, Land \& Water .......................................................................................................................... 11

Division of Geological \& Geophysical Surveys .....................................................................................................11

Alaska Geologic Materials Center .................................................................................................................11

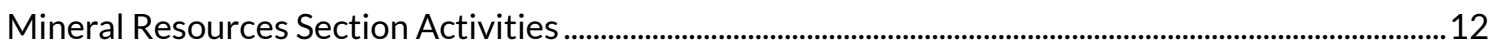

Geophysical Datasets ..........................................................................................................................13

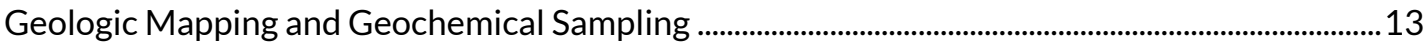

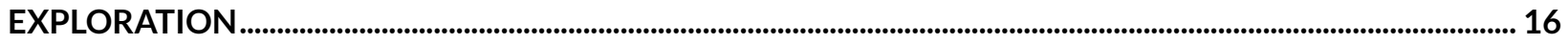

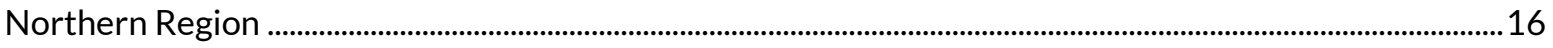

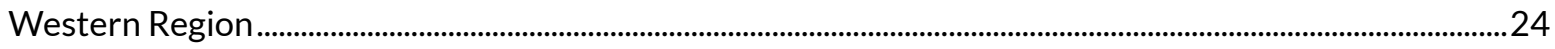

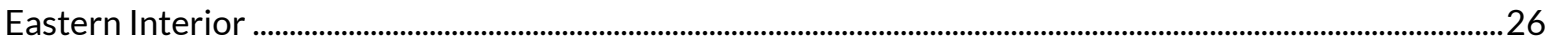

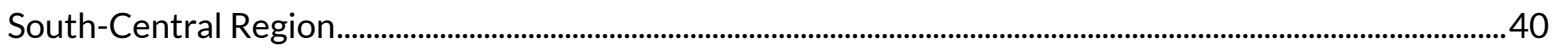

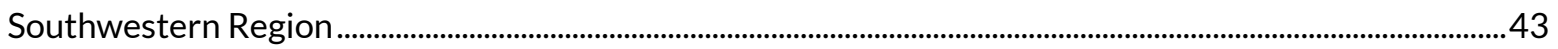

Southeastern Region ............................................................................................................................................

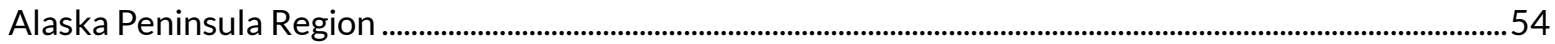

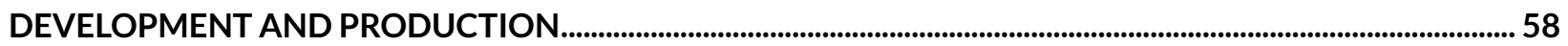

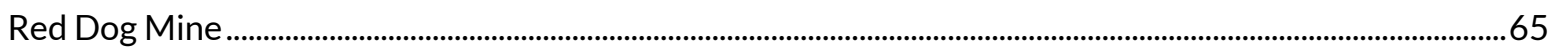

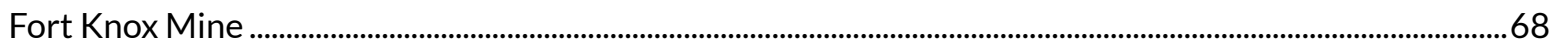

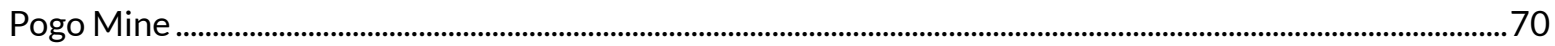

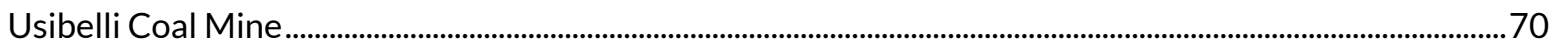

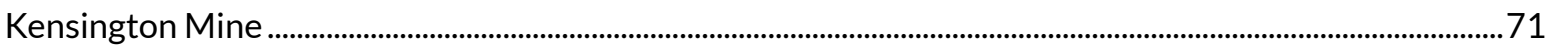

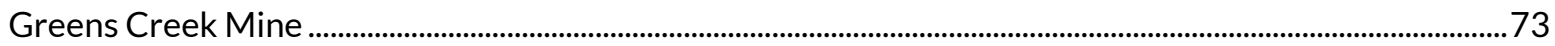

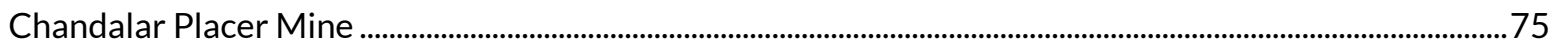

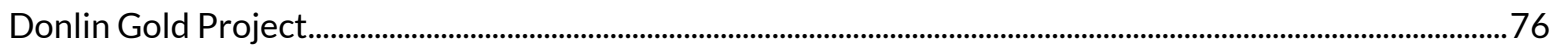

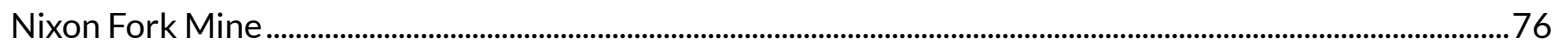

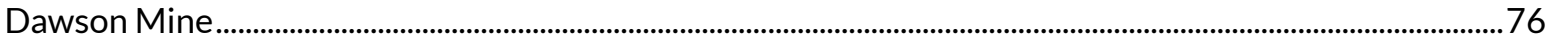

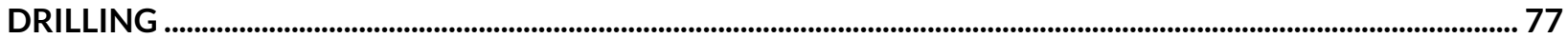

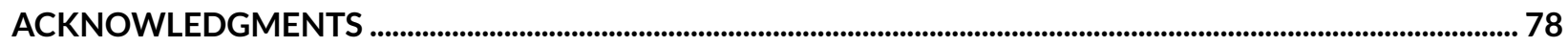

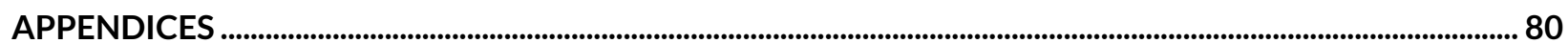

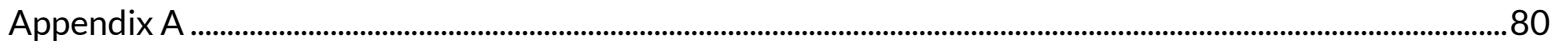

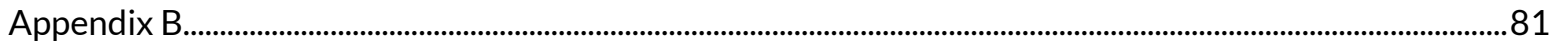

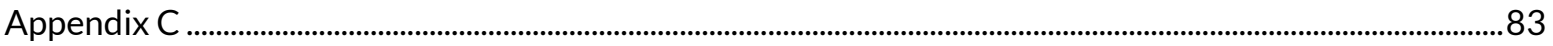

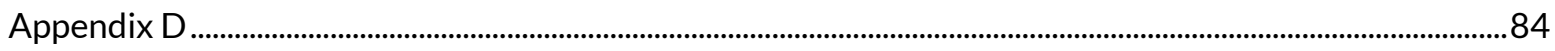

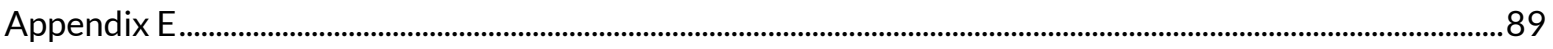

Figures

Figure 1. Regions of mineral activity as described in this report ..........................................................................1

Figure 2. Modern airborne geophysical data coverage of Alaska....................................................................14

Figure 3. Selected exploration projects in Alaska, 2017 ......................................................................................17

Figure 4. Alaska mineral exploration expenditures, 1956-2017 ...........................................................................18

Figure 5. Exploration expenditures by deposit type, 2017 ................................................................................18 
Figure 6. Aktigiruq pre-2017 drill hole location map... . .19

Figure 7. Map of PolarX's Alaska Range Project prospects and occurrences....................................................32

Figure 8. Map of Endurance Gold Corporation's Elephant Mountain project area..........................................35

Figure 9. Map of prospects on Avidian Gold Alaska Inc.'s Golden Zone property ..........................................38

Figure 10. Greens Creek mine plan map showing location of ore bodies ........................................................47

Figure 11. Map of Kensington, Raven, and Jualin deposits .................................................................................49

Figure 12. Northwest section view of Kensington Main ore bodies ..................................................................50

Figure 13. Northwest section view of Jualin ore bodies ..........................................................................................50

Figure 14. Drill hole location and prospect map for Redstar Gold Corporation's

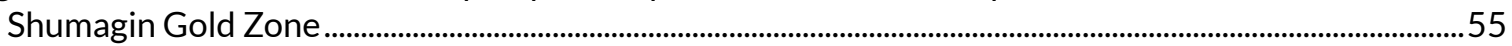

Figure 15. Selected development projects and mines in Alaska, 2017 ............................................................59

Figure 16. Estimated 2017 mineral production in Alaska by commodity .......................................................62

Figure 17. Historical gold production in Alaska, 1880-2017, and corresponding market value ..............62

Figure 18. Rock, sand, and gravel production in Alaska, 1950-2017 .............................................................63

Figure 19. Alaska coal production and exports, 1915-2017 …………………….............................................65

Figure 20. Cross section through Red Dog mine bodies looking west ................................................................67

\section{Tables}

Table 1. Reported annual exploration and development expenditures of the mineral industry....................3

Table 2. Estimated Alaska mineral industry employment, 2008-2017 ................................................................5

Table 3. Reported and estimated revenues paid to the State of Alaska and municipalities............................8

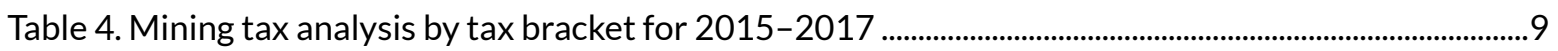

Table 5. New mineral resource-related DGGS publications in 2017 .................................................................13

Table 6. DGGS-managed, Federally funded detailed airborne geophysical survey work as of

December 2017 .............................................................................................................................................15

Table 7. Reported exploration expenditures in Alaska by commodity, 1981-2017 .........................................20

Table 8. Summary of claim activity, 1991-2017 …………………….................................................................21

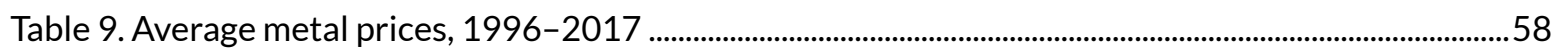

Table 10. Reported mineral development expenditures in Alaska by commodity, 1982-2017.................60

Table 11. Estimated mineral production in Alaska, 2015-2017 ........................................................................61

Table 12. Production and employment estimates for Alaska placer gold mines, 2014-2017 ....................63

Table 13. Material sale volumes by region reported on State-ownded land ....................................................64

Table 14. Alaska international mineral export values..................................................................................................64

Table 15. Red Dog mine production statistics, 1989-2017 ................................................................................66

Table 16. Fort Knox mine production statistics, 1996-2017 ..............................................................................68

Table 17. Pogo mine production statistics, 2006-2017 .......................................................................................... 71

Table 18. Kensington mine production statistics, 2010-2017 ……………………..............................................72

Table 19. Greens Creek mine production statistics, 1989-2017 ......................................................................74

Table 20. Companies publicly reporting significant drilling programs in Alaska in 2017.............................77

Table 21. Drilling footage reported or estimated in Alaska, 1982-2017..........................................................78

\section{Photos}

Photo 1. Crew poses before the Humbolt Portal, one of two portals completed in 2017 for the Dawson Mine near Ketchikan ……………………..........................................................................................

Photo 2. The Geologic Materials Center (GMC) facility in Anchorage, Alaska..................................................12

Photo 3. Core samples at the GMC donated by Doyon, Limited and Cook Inlet Regional Inc.....................12

Photo 4. The DGGS Mineral Resources team mapped the Taurus and Bluff $\mathrm{Cu}-\mathrm{Mo}-\mathrm{Au}$ porphyry deposits during the first of a two-year project in the northeast Tanacross area...... 
Photo 5. Through a 50/50 joint venture between Trilogy Metals Inc. and South32 Limited, South32 funded a \$10 million drill program targeting the northeast-dipping continuation of the high-grade-copper South Reef and New Reef zones at Bornite.

Photo 6. 2017 drilling encountered quartz-sericite-pyrite and argillic alteration in the Round Top copper-molybdenum porphyry system in western Alaska.

Photo 7. Handlers move core at the Peak project in eastern interior Alaska.

Photo 8. Drilling at the copper-molybdenum intrusion-related Shorty Creek project northwest of Fairbanks.

Photo 9. Chris Puchner, International Tower Hill's Livengood project Chief Geologist, looks over core

Photo 10. Senator prospect copper anomaly in gossan along the ridge, looking to the northeast............34

Photo 11. Endurance Gold Corporation trench sampled a gold-bearing structure at the South Fork target of the Trout property.

Photo 12. Zach Flood and Francis MacDonald from Kenorland Minerals conducted reconnaissance exploration in 2017 at the Taurus copper-gold-molybdenum-silver porphyry property, part of their Tanacross project.

Photo 13. 2017 drill results at Avidian's Golden Zone property extended the mineralized zone outside of the Breccia Pipe deposit area.

Photo 14. Rhyolite Resources Ltd. conducted prospecting for gold targets and geological mapping in their Paxson project area in 2017.

Photo 15. Photo of garnet-bearing heavy mineral concentrate from Icy Cape, northwest of Yakutat in the Gulf of Alaska

Photo 16. Boart Longyear's LS600 sonic drill rig in action at Icy Cape in the Gulf of Alaska

Photo 17. Donlin Gold, LLC conducted a 16-hole drilling program to improve on their resource model and feasibility study.

Photo 18. Roof bolter at Hecla's Greens Creek mine prepares the underground area for additional work

Photo 19. 2017 drilling in the Palmer project's South Wall Zone intersected high-grade mineralization

Photo 20. Grande Portage Resources Ltd.'s drilling encountered visible gold and disseminated arsenopyrite, pyrite, galena, and sphalerite in the Main, Deep Trench, and Goat veins at the Herbert Gold project near Juneau.

Photo 21. Copper-molybdenum-gold mineralization at CopperBank Resources Corp.'s Pyramid project on the Alaska Peninsula.

Photo 22. Kinross Gold Corporation's Fort Knox mine north of Fairbanks processed $13,744,703$ tons of ore through the mill

Photo 23. Coeur Alaska employed 367 full-time, year-round workers at the Kensington mine near Juneau in 2017

Photo 24. Goldrich NyacAU Placer, LLC's Chandalar gold mine, 190 miles north of Fairbanks, produced 14,670 ounces of placer gold from about June 4 through September 27, 2017

Photo 25. View looking north from Pyramid project drill site 17PYR033 on the Alaska Peninsula ........79 
This page intentionally left blank. 
This page intentionally left blank. 


\section{INTRODUCTION}

\section{Alaska ranks top ten in the (known) global distribution of major metals and coal}

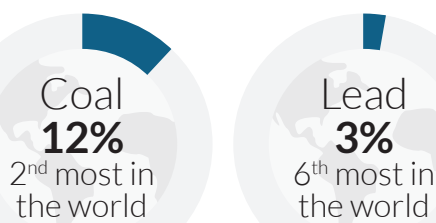

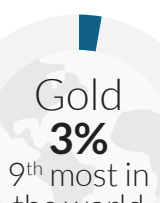

the world

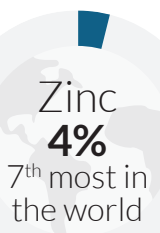

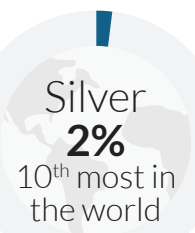

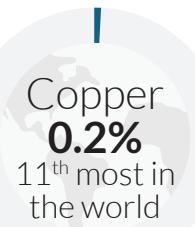

Alaska's mineral potential is evident from its historically significant production: placer gold from the Fairbanks and Nome mining districts, copper from the Kennecott area, lode gold from the Alaska-Juneau (A-J) and Treadwell mines
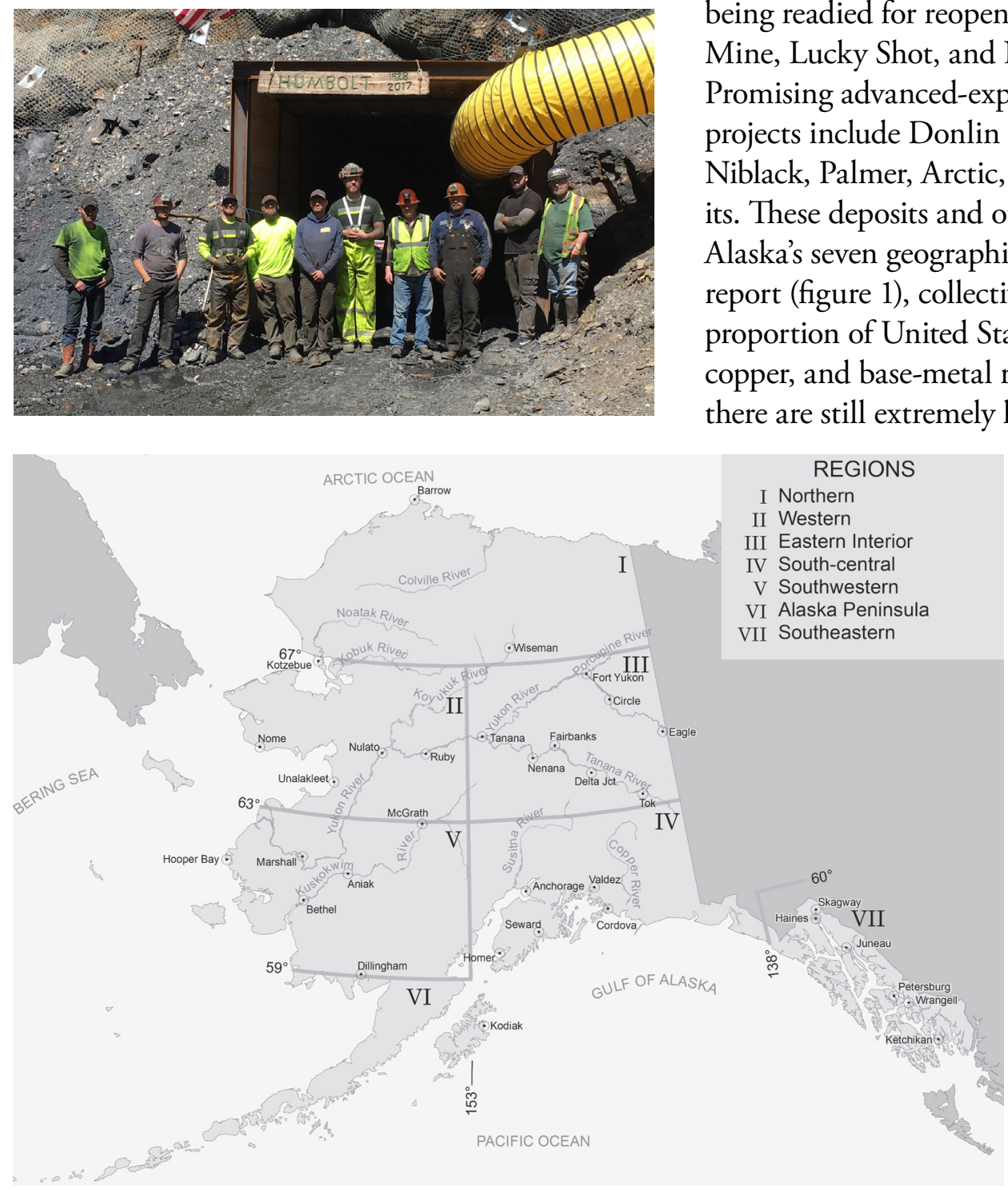

near Juneau, and placer platinum from the Goodnews Bay mining district. Alaska's major deposits currently in production include Red Dog, Greens Creek, Pogo, Fort Knox, Kensington, and Usibelli Coal mines, and several former gold producers being readied for reopening include the Dawson Mine, Lucky Shot, and Nixon Fork (photo 1). Promising advanced-exploration and development projects include Donlin Gold, Pebble, Livengood, Niblack, Palmer, Arctic, Bornite, and Lik deposits. These deposits and others, found throughout Alaska's seven geographic regions defined for this report (figure 1), collectively represent a significant proportion of United States domestic gold, silver, copper, and base-metal resources and indicate that there are still extremely large mineral deposits to be

Photo 1, above. Crew poses before the Humbolt Portal, one of two portals completed in 2017 for the Dawson Mine near Ketchikan. The former mine operated intermittently from the 1930s to 1952 , producing almost 10,000 ounces of gold, according to its ARDF record. Photo courtesy of Robert Fithian, Sundance Mining Group LLC.

Figure 1, left. Regions of mineral activity as described in this report. 


\section{Tracking Alaska's mineral industry: Estimated revenue to industry} versus theoretical first market value

This report began a new method of tracking the value of Alaska's mineral production starting with the 2016 mining year. 'Estimated revenue to industry', as reported voluntarily by mining companies, is now the primary method for tabulating annual mine production in Alaska; 'estimated first market value' figures tabulated prior to 2016 have now been more accurately retitled 'theoretical first market value' (table 1). The new 'estimated revenue to industry' figure accounts for actual sales revenue, including the effects of stockpiling, price hedging, the price at the time of sale, smelting and refining charges, and transportation of the final product. The 'theoretical first market value' figure simply reflects the total amount of each commodity produced multiplied by the average price for that year; the simplicity of this approach means that the theoretical first market value figure can significantly overstate the revenue realized by the operator. For example, there is a nearly $\$ 600$ million difference between estimated revenue received by operators in 2017 and the theoretical first market value for 2017 . When actual revenue values are either not voluntarily reported or must be withheld for reasons of confidentially, theoretical first market values will be used instead. In the "Government Revenues from Alaska's Mineral Industry" section, gross income from mining operations as reported on Alaska Mining License Tax returns and explanatory text are also available for comparison with the estimated revenue to industry value.

developed in Alaska. Significant resources of other commodities, including the Graphite Creek graphite deposit and the Bokan Mountain rare-earth-element deposit, promise future domestic sources of critical raw materials needed for twenty-first-century technologies. Without a doubt, Alaska holds other world-class mineral deposits yet to be discovered. In 2017 Alaska was ranked $5^{\text {th }}$ out of 91 worldwide jurisdictions for mineral potential by mining and exploration companies. Alaska also ranked $10^{\text {th }}$ for overall investment attractiveness, which takes into account geologic potential as well as government policy factors that affect exploration investment. ${ }^{2}$

It is the policy of the State of Alaska to encourage the settlement of its land and the development of its resources by making them available for maximum use consistent with the public interest. Alaska, in its strategic Pacific Rim location, offers prospective land, sanctity of title, State-sponsored geological and geophysical mapping, a reasonable permitting process coordinated among agencies, a capable workforce, exploration incentives, and innovative infrastructure equity-sharing programs. More than 190 million acres of Federal, State, and Native-owned lands are open for mineral-related activities and mining. This allows the minerals industry to be a driving force in the State's economy through significant local employment, infrastructure, and government revenue.

In line with positive trends in the health of the global mining industry, 2017 exploration activity in Alaska rebounded to a level not seen since 2013. Alaska exploration expenditures more than doubled in 2017 to $\$ \mathbf{1 2 0 . 8}$ million, an increase of 105 percent from $\$ 58.9$ million in 2016 (table 1). On a similarly encouraging note, the area of new mining claims and prospecting sites staked statewide in 2017 increased by more than 230 percent, and the total area of the State claimed for mining increased 16 percent to almost three million acres. Development

2Stedman, Ashley, and Green, K.P., 2018, Fraser Institute Annual Survey of Mining Companies, 2017: Vancouver, BC, Fraser Institute, 68 p. https://www.fraserinstitute.org 
expenditures in Alaska, an indicator of future production, totaled $\$ 299.5$ million in 2017 , up 38 percent from $\$ 217.4$ million in 2016.
Although the quantities of all commodities produced in 2017 were lower, higher metal prices buoyed total mining revenue to Alaska

Table 1. Reported annual exploration and development expenditures of the mineral industry, the estimated theoretical first market value of mineral production in Alaska, and estimated revenue to the mineral industry from the sale of those commodities (in millions of dollars), 1981-2017. Average annual values are given for 19811985, 1986-1990, 1991-1995, and 1996-2000; individual year totals are provided for 2001-2017.

\begin{tabular}{|c|c|c|c|c|}
\hline Year & $\begin{array}{l}\text { Exploration } \\
\text { Expenditures } \\
\text { (\$ millions) }\end{array}$ & $\begin{array}{l}\text { Development } \\
\text { Expenditures } \\
\text { (\$ millions) }\end{array}$ & $\begin{array}{c}\text { Theoretical First } \\
\text { Market Value } \\
\text { (\$ millions) }^{\mathrm{a}}\end{array}$ & $\begin{array}{c}\text { Estimated Revenue } \\
\text { to Industry } \\
\text { (\$ millions })^{\mathrm{b}}\end{array}$ \\
\hline 1981-1985 & $\$ 37.5$ & $\$ 36.3$ & $\$ 204.7$ & -- \\
\hline 1986-1990 & $\$ 36.2$ & $\$ 109.6$ & $\$ 288.6$ & -- \\
\hline 1991-1995 & $\$ 33.2$ & $\$ 55.3$ & $\$ 520.1$ & -- \\
\hline $1996-2000$ & $\$ 49.4$ & $\$ 158.7$ & $\$ 917.4$ & -- \\
\hline 2001 & $\$ 23.8$ & $\$ 81.2$ & $\$ 917.3$ & -- \\
\hline 2002 & $\$ 26.5$ & $\$ 34.0$ & $\$ 1,012.8$ & -- \\
\hline 2003 & $\$ 27.6$ & $\$ 39.1$ & $\$ 1,000.7$ & -- \\
\hline 2004 & $\$ 70.8$ & $\$ 209.1$ & $\$ 1,338.7$ & -- \\
\hline 2005 & $\$ 103.9$ & $\$ 347.9$ & $\$ 1,401.6$ & -- \\
\hline 2006 & $\$ 178.9$ & $\$ 495.7$ & $\$ 2,858.2$ & -- \\
\hline 2007 & $\$ 329.1$ & $\$ 318.8$ & $\$ 3,367.0$ & -- \\
\hline 2008 & $\$ 347.3$ & $\$ 396.2$ & $\$ 2,427.1$ & -- \\
\hline 2009 & $\$ 180.0$ & $\$ 330.8$ & $\$ 2,455.6$ & -- \\
\hline 2010 & $\$ 264.4$ & $\$ 293.3$ & $\$ 3,126.8$ & -- \\
\hline 2011 & $\$ 365.1$ & $\$ 271.9^{c}$ & $\$ 3,507.7$ & -- \\
\hline 2012 & $\$ 335.1$ & $\$ 342.4$ & $\$ 3,436.1$ & -- \\
\hline 2013 & $\$ 175.5$ & $\$ 358.8$ & $\$ 3,418.7$ & -- \\
\hline 2014 & $\$ 96.2$ & $\$ 281.7$ & $\$ 3,282.1$ & -- \\
\hline 2015 & $\$ 58.3$ & $\$ 309.9^{c}$ & $\$ 2,759.2$ & -- \\
\hline 2016 & $\$ 58.9$ & $\$ 217.4$ & -- & $\$ 2,536.6$ \\
\hline 2017 & $\$ 120.8$ & $\$ 299.5$ & -- & $\$ 2,724.7$ \\
\hline
\end{tabular}

Exploration, development, and production figures are provided in Alaska's Mineral Industry reports published annually by DGGS and sister agencies.

aTheoretical first market value is calculated by multiplying reported commodity amounts produced for a calendar year by the average yearly price per unit. This figure may significantly overestimate the value of the commodity, because it assumes that the commodity is a pure, final product and the operator has incurred no additional charges during its production.

${ }^{b}$ Estimated revenue to industry is compiled from 1) revenue figures reported for the calendar year by major mine operators (accounting for actual sale prices and including smelting and refining charges and transportation costs), except a theoretical first market value is substituted when actual mine revenue is unavailable; 2) calculated value of industrial materials (rock, sand, and gravel) produced from some State and Federals lands (table 11); and gross operating income of placer mining operations from Mining License Tax forms as reported by the Department of Revenue (table 12).

c2011 and 2015 total missing significant expected data

- - = Not reported 
companies to $\$ 2.7$ billion, up seven percent from $\$ 2.5$ billion in 2016 .

The exploration, development, and production values used in this report are compiled from past-year statements issued by companies, including press releases and corporate annual and financial reports, as well as phone interviews, replies to questionnaires, and news media articles. Average metal prices used in the first-market-value calculations that are incorporated into estimated mining revenues and commodity values are based on average daily prices on the London Metal Exchange. Coal prices are estimated from average coal prices for similar grade material around the Pacific Rim. Industrial materials prices are based on regional rates reported by operators. Many of the numbers contained in this report are estimates; commodity values and company revenue estimated from theoretical first market values are likely to be overstated, while numbers based on voluntary reporting are likely to be minimum estimates of the value of the mining industry to Alaska's economy.

This report is a cooperative project led by the Alaska Division of Geological \& Geophysical Surveys (DGGS) in the Department of Natural Resources (DNR), with support from the DNR Division of Mining, Land \& Water (DMLW), the Department of Labor and Workforce Development (DLWD), and the Department of Revenue (DOR). The agencies involved in producing this report are committed to producing a reliable annual commentary on mineral industry activity in Alaska, which is vital for informed decision-making by State and local governments, the Legislature, land managers, industry, Native corporations, and the public.

\section{EMPLOYMENT}

Employment gains in 2017 mirror the upturn in mining company spending. Total mineral industry employment in 2017 is estimated at 3,392 full-time-equivalent jobs, an overall increase of about 160 jobs (5 percent) from 2016 (table 2).
The exploration sector added an estimated 94 jobs, up 59 percent from 2016. Exploration employment was estimated for 25 of 58 lode exploration projects using their reported exploration expenditure and (or) drilling footage in conjunction with cost-per-project ratios averaged from 32 and 18 projects with complete employment or drilling data, respectively.

Development gained 124 jobs while production lost 58, a net gain of 66 positions (2 percent). Changes in the number of development and production jobs likely reflect new hires for development projects and job reallocation from production to development at mine sites - given that development expenditures increased by $\$ 75.4$ million and production expenditures decreased by $\$ 94.3$ million at Alaska's mines in 2017. Note that most large operators do not differentiate production from development employment, and since 2014, development and production employment, when not specifically provided by the operator, have been estimated for large operations based on their reported ratio of production to development expenditures.

Placer mining employment fell another 13 percent in 2017 with 29 jobs lost. Placer mines have continuously lost employment since a high of 477 full-time-equivalent jobs in 2012 that coincided with the peak in the price of gold. Placer mine employment is challenging to quantify, due to the large number of small or seasonal operations, sole-proprietors, and family-based businesses. Placer mining employment in 2017 was estimated from the number of placer mines that reported gross operating income on Mining License Tax returns, a new methodology fully explained in table 12.

Mine Safety and Health Administration (MSHA) data indicate that materials production (rock, sand, and gravel) full-time-equivalent employment decreased by 11 percent (11 jobs). ${ }^{3}$ Reported material-sale volumes also decreased by 33 percent in 2017. While the industrial materials sector is still underreported, the MSHA dataset

${ }^{3}$ Mine Safety and Health Administration, Employment/Production Data Set (dataset 9); last accessed September 17, 2018 ; https://arlweb.msha.gov/OpenGovernmentData/OGIMSHA.asp 
captures its employment more completely than past voluntary reporting through questionnaires.

This report relies on a variety of sources to tabulate mineral industry employment, including publicly available company documents, personal communications, and questionnaires sent out by DGGS. Many exploration companies and mine operators voluntarily responded to questionnaires with 2017 employment information. Affidavits of Annual Labor also provided 2017 employment data for hard-rock exploration projects. Additional employment information was obtained from MSHA. These datasets and sources represent a minimum estimate and an incomplete picture of mineral industry employment in Alaska, but the values that are available add to the statewide mining employment total and provide a more complete estimate of the impact of mining to the State's workforce and wealth-generation potential. Except for placer employment, full-time-equivalent positions are based on a 260-day work year and 10-hour work day unless actual average annual employment numbers are provided.

The Alaska Department of Labor and Workforce Development (DLWD) provided 2017 mining employment and wage statistics based on 109 reporting units (companies) consisting of 51 metal ore, $36 \mathrm{coal}$ and nonmetallic-mineral quarrying, and 22 mining-support-activity units. Among companies in 2017, mining and support

Table 2. Estimated Alaska mineral industry employment, 2008-2017, a as compiled from public documents, MSHA

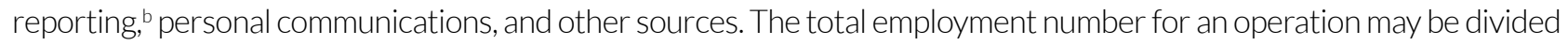
among exploration, development, and production activities based on the reported expenditures in those categories.

\section{$\begin{array}{llllllllll}2008 & 2009 & 2010 & 2011 & 2012 & 2013 & 2014 & 2015 & 2016 & 2017\end{array}$}

\begin{tabular}{|c|c|c|c|c|c|c|c|c|c|c|}
\hline Placer & 282 & 399 & 405 & 439 & 477 & 432 & 241 & $224^{e}$ & 222 & 193 \\
\hline Lode & 739 & 832 & 1,008 & 1,085 & 1,206 & 1,176 & 1,054 & 1,047 & 1,253 & 1,193 \\
\hline Polymetallic mining & 317 & 321 & 350 & 364 & 386 & 390 & 287 & 303 & 306 & 324 \\
\hline Base metals mining & 475 & 413 & 550 & 586 & 530 & 550 & 446 & 475 & 526 & 606 \\
\hline Recreational mining & 30 & 36 & 35 & 41 & 52 & 55 & 7 & -- & -- & -- \\
\hline Industrial minerals & & & & & & & & 173 & 253 & 197 \\
\hline Sand and gravel & 277 & 286 & 313 & 307 & 424 & 565 & 30 & -- & -- & -- \\
\hline Rock & 93 & 83 & 11 & 28 & 60 & 19 & 65 & - - & -- & -- \\
\hline Coalc & 110 & 117 & 140 & 140 & 144 & 120 & 115 & 112 & 100 & 89 \\
\hline Peat ${ }^{c, d}$ & 7 & -- & 3 & 3 & 4 & - - & $<1$ & -- & - - & -- \\
\hline $\begin{array}{l}\text { Tin, jade, soapstone, } \\
\text { ceramics, platinum }\end{array}$ & -- & -- & - - & - - & -- & 1 & 1 & -- & -- & -- \\
\hline $\begin{array}{l}\text { Production (total of } \\
\text { above categories) }\end{array}$ & 2,330 & 2,487 & 2,815 & 2,993 & 3,283 & 3,308 & 2,246 & 2,230 & 2,660 & 2,602 \\
\hline Mineral development & 516 & 371 & 537 & 422 & 535 & 358 & 468 & 555 & 412 & 536 \\
\hline Mineral exploration & 546 & 422 & 520 & $535^{f}$ & 548 & 385 & 253 & 116 & 160 & 254 \\
\hline Total & 3,392 & 3,280 & 3,872 & 3,950 & 4,366 & 4,051 & 2,967 & 2,901 & 3,232 & 3,392 \\
\hline
\end{tabular}

\footnotetext{
aReported man-days are calculated on a 260-day work year and 10-hour work day to obtain average annual employment unless actual average annual employment numbers are provided.

'MSHA data: https://arlweb.msha.gov/OpenGovernmentData/DataSets/MinesProdYearly.zip

'Coal and peat employment numbers are combined in 2009.

'This figure does not include all of the man-days associated with peat operations; most of those man-days are included in sand and gravel numbers.

eValue was updated to estimate calculated from Department of Revenue data. See table 12 for information on placer employment calculations.

${ }^{f}$ Average of 520-550 range reported for 2011.

- - = Not reported

See Exploration, Development, and Production sections for further details.
} 
activities provided 3,076 jobs, up four percent from 2,945 jobs in 2016; jobs increased 36 percent in the mining support sector alone. DLWD data show that nonmetallic mineral-product manufacturing provided 248 jobs, which includes an average of 243 jobs in cement and concrete manufacturing for 2017. Primary metal manufacturing provided 13 jobs, while metal and mineral merchant wholesalers provided an average of 114 jobs during 2017.

According to DLWD data, 23 boroughs or census areas reported mining (excluding oil and gas) employment in 2017. Juneau, Anchorage, and Fairbanks area (combined Fairbanks North Star Borough and Southeast Fairbanks Census Area) each had more than 100 mining jobs, accounting for 55 percent of mining employment in the State. The City and Borough of Juneau had the highest number of jobs in mining (821). The greater Fairbanks area came in second with 739 jobs, down 39 percent from 1,209 jobs in 2016 and with five fewer businesses paying wages for mining-related work. ${ }^{4}$

Wages for mining-sector jobs, averaging $\$ 107,820$ in 2017 , were some of the highest among major industries in Alaska and were more than twice the average private-sector wage of $\$ 52,121$ per year. Total wages paid by non-oil-and-gas mining firms in 2017 were $\$ 308,689,085$, up almost two percent from 2016. Total wages paid by mining-support firms in 2017 were $\$ 19,320,096$, a 54 percent increase from 2016 likely due to the increased number of exploration projects needing support services. DLWD employment is based on wage records and includes part-time jobs but does not include the self-employed and working family members not covered under unemployment insurance. The majority of placer operators are self-employed and are therefore not counted in the DLWD data. Employment data may not include jobs in the exploration and development phases of mining at geological and engineering consulting firms that are categorized in the engineering, environmental, or construction industries. Consequently, mining's contributions to employment and earnings in Alaska are likely understated by DLWD's dataset. ${ }^{4}$

An in-depth report on the economic impact of the mining industry in Alaska prepared by the McDowell Group for the Alaska Miners Association (AMA) estimates that in 2017, Alaska's mining industry provided 4,500 direct mining jobs and an additional 4,500 indirect and induced jobs. Direct, indirect, and induced wages totaled an estimated $\$ 700$ million. The McDowell report uses surveys and other research and analysis in an effort to include mining industry employment not captured by the DLWD and DGGS datasets. Mining employees, not including placer and materials production, live in at least 55 communities throughout Alaska.

\section{GOVERNMENT REVENUES FROM ALASKA'S MINERAL INDUSTRY}

In 2017 government revenue from Alaska's mineral industry totaled $\$ 120.6$ million (table 3 ). The 73 percent increase from $\$ 69.5$ million in 2016 is due primarily to increased revenue from Alaska's Mining License Tax, which is reported for the State fiscal year (FY 2017, July 1, 2016June 30, 2017), and larger payments to municipalities. Table 3 provides an itemized listing of estimated revenues paid to the State and municipalities. These revenues are incomplete and serve only as a minimum. Additionally, DNR reported that $\$ 96,350$ was received in bond pool payments in 2017. Bond pool payments, which are reclamation financial assurance and not considered State revenue, may only be used to reclaim sites disturbed by mining activities.

Revenues from State Corporate Income Tax have declined year over year since 2013, tracking with metal prices that began sliding in 2012.

${ }^{4}$ State of Alaska Department of Labor and Workforce Development (DLWD), Research and Analysis Section, Quarterly Census on Employment and Wages (QCEW); last accessed September 17, 2018; http://live.laborstats.alaska.gov/qcew/ee17.pdf

${ }^{5}$ Alaska Miners Association, The Economic Benefits of Alaska's Mining Industry, March 2018; last accessed September 4, 2018; https://www.dropbox.com/s/hkfnimhnpreciul/McDowell\%20In\%20Depth\%202018.pdf?dl=1 
According to the Department of Revenue, the impacts of the large drop in metal prices during 2015-2016 were still felt in FY 2017, even though metal prices rebounded towards the end of FY 2017. This likely is due to two factors. First, timing differences between tax years and fiscal years add complexity. Companies made estimated payments for the 2015 calendar year while mineral prices were high. The companies sought refunds of these payments as late as during FY 2017, as they learned that they didn't actually owe the tax that the estimated payments were made in anticipation of. Second, mining companies have the ability to apply losses as a deduction against positive corporate income. Losses incurred during 2016 could be used to cancel out positive income earned in 2017. This likely caused overall corporate tax collected in FY 2017 to be negative for the mining sector.

Gross income for 2017 of $\$ 2.536$ billion is compiled from the Mining License Tax returns filed by all taxed mining operators in Alaska and indicates the income received for commodities sold during the tax year (December 1, 2016-November 30, 2017; table 4). Gross income differs from the 2017 'estimated revenue to industry' of $\$ 2.7$ billion in table 1 , because the latter is compiled for the calendar year and includes some theoretical first market values of mineral production that may not have been sold during that time period, as well as the value of untaxed sand and gravel products. Note that table 4 excludes royalty-only taxpayers; royalty-only taxpayers are typically landowners who receive revenue solely from a royalty share, with no gross income from mining operations. All six major mines in Alaska earn gross income from mining operations and their income is included in the table's values.

Mining License Tax collections, which were significantly impacted by a sharp decline in metal prices during the first half of FY 2016 (July 1, 2015-January 1, 2016), rebounded in FY 2017 to more than $\$ 41$ million. The Mining License Tax, unlike the Corporate Income Tax, does not have loss carryforward or carryback provisions. As mineral prices rebounded during FY 2017, collections returned to normal, with no "hangover" (as with the Corporate Income Tax). DOR reported that 448 taxpayers submitted Mining License Tax returns in 2017, of which 37 (8 percent) were liable for taxes on net taxable income from mining in the amount of $\$ 617.3$ million, a 253 percent increase over 2016 net taxable income (table 4). Negative net taxable incomes from mining at an average loss of $\$ 243,935$ per taxpayer were reported by 164 taxpayers.

Revenue to municipalities increased in 2017 to $\$ 48.4$ million (73 percent) over 2016 because of a larger payment from the Red Dog mine to the Northwest Arctic Borough, as well as more complete reporting in general from mines, boroughs, and municipalities. In Juneau, Fairbanks, and the Northwest Arctic Borough, revenue from mining-related activity was among the largest contributors to municipal and borough budgets. In addition, the mining industry paid almost $\$ 276.5$ million to Native corporations. Alaska communities also received more than $\$ 2.9$ million in charitable donations from the mining industry.

AMA's McDowell report on mining lists other benefits to the State that are not tracked in table $3 .^{5}$ For example, a portion of Alaska's mining industry rents and royalty payments are deposited in the Alaska Permanent Fund annually. In 2017 the Permanent Fund earned $\$ 5.2$ million from the mining industry. In FY 2017, the Alaska Railroad Corporation received approximately $\$ 21.2$ million from movement of coal and rock, sand, and gravel (representing about 31 percent of the railroad's total revenue from freight). Annually, McDowell estimates that Alaska's mining industry purchases millions of dollars of goods and services (\$580 million in 2016) from Alaska vendors in support of operations and, in some jurisdictions, pays sales taxes to local governments on these purchases. 
Table 3. Reported and estimated revenues paid to the State of Alaska and municipalities by Alaska's mineral industry, 2012-2017. The figures in this table will change as data are reviewed and updated; the table has been significantly updated to reflect Department of Natural Resources and Department of Revenue reporting for previous years. See footnotes for reporting sources and dates.*

\begin{tabular}{|c|c|c|c|c|c|c|c|}
\hline & & 2012 & 2013 & 2014 & 2015 & 2016 & 2017 \\
\hline \multicolumn{8}{|c|}{ State mineral rents and royalties ${ }^{a, b}$} \\
\hline State claim rentals & & $7,951,003$ & $7,507,976$ & $6,740,816$ & $6,920,029$ & $7,327,630$ & $7,658,003$ \\
\hline Production royalties ${ }^{c}$ & & $8,982,259$ & $9,808,575$ & $7,004,376$ & $4,608,137$ & $2,816,884$ & $3,125,925$ \\
\hline Annual labor & & 357,500 & 542,588 & 389,807 & 321,419 & 331,986 & 374,244 \\
\hline Subtotal & $\$$ & $17,290,762$ & $17,859,139$ & $14,134,999$ & $11,849,585$ & $10,476,500$ & $11,158,173$ \\
\hline \multicolumn{8}{|l|}{ State coal rents and royalties ${ }^{b}$} \\
\hline Rents & & 186,204 & 324,393 & 315,398 & 351,724 & 347,324 & 268,866 \\
\hline Royalties ${ }^{c}$ & & $2,921,491$ & $2,757,444$ & $2,514,532$ & $2,430,267$ & $2,237,777$ & $2,232,394$ \\
\hline Bonus & & $3,025,000$ & -- & 38,005 & 111,000 & -- & -- \\
\hline Subtotal & $\$$ & $6,132,695$ & $3,081,837$ & $2,867,935$ & $2,892,992$ & $2,585,101$ & $2,501,260$ \\
\hline \multicolumn{8}{|l|}{ State material Sales } \\
\hline Mental Health & & 11,876 & $-7,854$ & 115,493 & 69,163 & 25,130 & 24,366 \\
\hline Division of Land ${ }^{b}$ & & $1,735,404$ & $4,965,386$ & $10,559,857$ & $11,293,545$ & $6,412,271$ & $4,637,844$ \\
\hline State Pipeline Coordinator's Office & & 30,746 & 340,786 & 105,330 & 197,644 & 121,994 & 288,511 \\
\hline Subtotal & $\$$ & $1,778,025$ & $5,298,318$ & $10,780,680$ & $11,560,352$ & $6,559,395$ & $4,950,720$ \\
\hline \multicolumn{8}{|l|}{ State mining miscellaneous fees ${ }^{b}$} \\
\hline Filing fees & & 6,274 & 3,350 & 3,350 & 2,100 & 9,650 & 4,825 \\
\hline Bid Bonus & & 465,850 & -- & 93,767 & -- & 193,963 & - \\
\hline Penalty fees & & 532,959 & 205,453 & 122,035 & 43,307 & 95,677 & 220,770 \\
\hline Exploration incentive app filing fee & & - & -- & -- & -- & -- & -- \\
\hline Surface mine investment interest & & 20,491 & 5,772 & 7,802 & 7,801 & 19,690 & - \\
\hline Surface coal mining app fee & & 2,200 & 22,800 & 1,300 & 21,700 & 7,218 & 8,000 \\
\hline APMA mining fees & & 45,055 & 32,953 & 26,511 & 24,302 & 21,627 & 21,302 \\
\hline Subtotal & $\$$ & $1,072,829$ & 270,329 & 254,764 & 99,210 & 347,826 & 254,897 \\
\hline \multicolumn{8}{|l|}{ Other Fees } \\
\hline AIDEA - Facilities use fees ${ }^{d}$ & & $12,600,000$ & $11,986,000$ & $11,986,000$ & $11,356,000$ & $10,709,000$ & $10,014,951$ \\
\hline State Fuel Taxes ${ }^{\mathrm{e}}$ & & 585,034 & 951,852 & Not reported & Not reported & $2,066,313$ & $1,338,843$ \\
\hline State corporate income tax & & $15,020,036$ & $26,812,498$ & $15,215,598$ & $17,320,051$ & $1,636,850$ & $-729,670$ \\
\hline Mining License Taxg & & $40,695,833$ & $46,787,690$ & $23,457,300$ & $38,665,209$ & $11,137,900$ & $41,525,192$ \\
\hline $\begin{array}{l}\text { Large Mine Permit Coordination } \\
\text { Program Receiptsh }\end{array}$ & & $2,614,863$ & $2,238,589$ & $1,919,659$ & $1,725,021$ & $1,364,952$ & 968,827 \\
\hline State Total & $\$$ & $97,790,077$ & $115,286,252$ & $80,616,934$ & $95,468,420$ & $46,883,837$ & $71,983,193$ \\
\hline Payments to Municipalities & & $21,529,472$ & $29,412,224$ & $18,525,615$ & $21,041,152$ & $22,656,383$ & $48,628,626$ \\
\hline Total & $\$$ & $119,319,549$ & $144,698,476$ & $99,142,549$ & $116,509,572$ & $69,540,220$ & $120,611,819$ \\
\hline
\end{tabular}

*See footnotes on opposite page. 
Table 4. Mining tax analysis by tax bracket for 2015-2017, based on Mining License Tax returns. Analysis excludes royalty-only taxpayers - those with positive royalties received but zero gross income from mining operations. Information provided by the Alaska Department of Revenue. The figures in this table will change as data are reviewed and updated.

2015 (December 2014 - November 2015)

\begin{tabular}{|c|c|c|c|c|c|c|c|c|c|}
\hline Bracket & $\begin{array}{l}\text { Marginal } \\
\text { rate }\end{array}$ & $\begin{array}{c}\text { No. } \\
\text { of } \\
\text { taxpayers }\end{array}$ & $\begin{array}{l}\text { Gross income } \\
\text { from mining } \\
\text { operations }\end{array}$ & $\begin{array}{l}\text { Net taxable } \\
\text { income* }\end{array}$ & $\begin{array}{c}\text { Net } \\
\text { income as } \\
\text { percentage } \\
\text { of gross }\end{array}$ & $\begin{array}{l}\text { Total tax } \\
\text { liability }\end{array}$ & $\begin{array}{l}\text { Average } \\
\text { gross } \\
\text { income }\end{array}$ & $\begin{array}{l}\text { Average } \\
\text { taxable } \\
\text { income }\end{array}$ & $\begin{array}{l}\text { Average } \\
\text { tax } \\
\text { liability }\end{array}$ \\
\hline Under $\$ 0$ & $0 \%$ & 191 & $\$ 181,380,675$ & $\$-48,850,623$ & $-27 \%$ & $\$ 0$ & $\$ 949,637$ & $-\$ 255,762$ & $\$ 0$ \\
\hline$\$ 0$ to $\$ 40,000$ & $0 \%$ & 228 & $\$ 9,051,119$ & $\$ 785,831$ & $9 \%$ & $\$ 0$ & $\$ 39,698$ & $\$ 3,447$ & $\$ 0$ \\
\hline $\begin{array}{c}\$ 40,001 \text { to } \\
\$ 100,000\end{array}$ & $3 \%, 5 \%$ & 8 & $\$ 2,594,126$ & $\$ 539,304$ & $21 \%$ & $\$ 19,018$ & $\$ 324,266$ & $\$ 67,413$ & $\$ 2,377$ \\
\hline Over $\$ 100,000$ & $7 \%$ & 10 & $\$ 2,306,213,104$ & $\$ 570,733,654$ & $25 \%$ & $\$ 39,921,356$ & $\$ 230,621,310$ & $\$ 57,073,365$ & $\$ 3,992,136$ \\
\hline Total & & 437 & $\$ 2,499,239,024$ & $\$ 523,208,166$ & & $\$ 39,940,374$ & & & \\
\hline \multicolumn{10}{|c|}{2016 (December 2015 - November 2016) } \\
\hline Under $\$ 0$ & $0 \%$ & 197 & $\$ 196,281,647$ & $\$-73,026,051$ & $-37 \%$ & $\$ 0$ & $\$ 996,354$ & $-\$ 370,691$ & $\$ 0$ \\
\hline$\$ 0$ to $\$ 40,000$ & $0 \%$ & 268 & $\$ 6,077,617$ & $\$ 938,492$ & $15 \%$ & $\$ 0$ & $\$ 22,678$ & $\$ 3,502$ & $\$ 0$ \\
\hline $\begin{array}{l}\$ 40,001 \text { to } \\
\$ 100,000\end{array}$ & $3 \%, 5 \%$ & 24 & $\$ 3,307,609$ & $\$ 1,113,192$ & $34 \%$ & $\$ 35,124$ & $\$ 137,817$ & $\$ 46,383$ & $\$ 1,464$ \\
\hline Over $\$ 100,000$ & $7 \%$ & 15 & $\$ 1,698,296,144$ & $\$ 173,657,633$ & $10 \%$ & $\$ 9,389,231$ & $\$ 113,219,743$ & $\$ 11,577,176$ & $\$ 625,949$ \\
\hline Total & & 504 & $\$ 1,903,963,017$ & $\$ 102,683,266$ & & $\$ 9,424,355$ & & & \\
\hline \multicolumn{10}{|c|}{2017 (December 2016 - November 2017) } \\
\hline Under $\$ 0$ & $0 \%$ & 164 & $\$ 168,828,407$ & $\$-40,005,277$ & $-24 \%$ & $\$ 0$ & $\$ 1,029,442$ & $-\$ 243,935$ & $\$ 0$ \\
\hline$\$ 0$ to $\$ 40,000$ & $0 \%$ & 247 & $\$ 10,399,818$ & $\$ 1,118,828$ & $11 \%$ & $\$ 0$ & $\$ 42,105$ & $\$ 4,530$ & $\$ 0$ \\
\hline $\begin{array}{l}\$ 40,001 \text { to } \\
\$ 100,000\end{array}$ & $3 \%, 5 \%$ & 24 & $\$ 4,890,085$ & $\$ 1,280,338$ & $26 \%$ & $\$ 42,686$ & $\$ 203,754$ & $\$ 53,347$ & $\$ 1,779$ \\
\hline Over $\$ 100,000$ & $7 \%$ & 13 & $\$ 2,352,232,870$ & $\$ 616,023,973$ & $26 \%$ & $\$ 41,254,411$ & $\$ 180,940,990$ & $\$ 47,386,459$ & $\$ 3,173,416$ \\
\hline Total & & 448 & $\$ 2,536,351,180$ & $\$ 578,417,862$ & & $\$ 41,297,097$ & & & \\
\hline
\end{tabular}

${ }^{*}$ Net income taxable under the Mining License Tax

Note: The 3\% bracket (income $\$ 40,000$ to $\$ 50,000$ ) and the $5 \%$ bracket $(\$ 50,000$ to $\$ 100,000$ ) are combined for this analysis because of confidentiality issues that would arise if each bracket were reported separately. Taxpayers with negative income (under \$0) are not a separate bracket, but are reported separately to distinguish between large money-losing operations and small operations with zero or positive income.

Footnotes for table 3, opposite.

ancludes upland lease and offshore lease rentals. Figures are reported by calendar year by the Alaska Department of Natural Resources.

${ }^{b}$ Figures are reported by calendar year by the Alaska Department of Natural Resources.

'Reported on a cash basis; payments actually received during the given year.

dAIDEA user fees for use of the State-owned roads and ports: the De Long Mountain Transportation System by Teck Alaska Inc., operator of the Red Dog mine; and for use of the Skagway Ore Terminal by Minto Explorations Ltd., a subsidiary of Capstone Mining Corp. (formerly Sherwood Copper Corp.). AIDEA figures are reported by fiscal year.

eln 2013, calculated on Fuel and Oil Expenditures from Mining Licenses Tax Form/Department of Revenue, assuming Alaska average fuel cost of \$6.09, https:// www.commerce.alaska.gov/web/dcra/researchanalysis/fuelpricesurvey.aspx. 2016 and 2017 values were reported by the major operating mines, less their fuel tax refund.

fOnly subchapter C corporations pay income tax. This report may not reflect $100 \%$ of the returns received in a year. The amount of corporate income tax reported in each fiscal year is the amount of tax actually received and may not agree with the amount reported on a corporation's tax return. This is due primarily to timing differences.

gIncludes metals, coal, and material for 2011. In 2012 and later, Mining License Tax was not collected on materials. http://www.tax.alaska.gov/programs/programs/ reports/Annual.aspx?60610\&Year $=2017$

hThe DNR, Office of Project Management and Permitting (OPMP) recovers costs from applicants for large mine permit coordination, per AS 38.05.020(b)(9) and AS 37.05.146(b)(3).

'Payments to Municipalities include property taxes, payments in lieu of taxes (PILT), and severance taxes. Data should be considered a minimum estimate. Data were primarily provided by the major operating mines. 


\section{MINERALS-RELATED GOVERNMENT ACTIVITIES}

\section{U.S. GEOLOGICAL SURVEY}

The U.S. Geological Survey (USGS) Mineral Resources Program had multiple projects focused on the geologic framework and mineral resources of Alaska in 2017. Alaska Science Center research staff in Anchorage coordinated field-based studies of the tectonic and metallogenic evolution of 1) the Lake Clark and Neacola Mountains region, south-central Alaska, 2) the Yukon-Tanana uplands, eastern Alaska, and 3) the Darby pluton area on the eastern Seward Peninsula. Research staff at the Geology, Geophysics, and Geochemistry Science Center in Denver conducted an exploration geochemistry pilot study near the Taurus porphyry copper deposit in eastern interior Alaska. The purpose is to identify whether indicator minerals in stream sediments may be useful in identifying mineralization in this part of Alaska.

Following the successful GIS-based evaluation of critical mineral potential in Alaska in 2016 (http://doi.org/10.3133/ofr20161191), research staff in Anchorage and Denver applied the GIS methodology to mapping the potential for lode gold associated with porphyry, reduced intrusion-related, epithermal, and orogenic deposits. Additional geochemical and geophysical datasets were added to the analysis to help reduce uncertainty in the evaluation rankings. Work continued on improving and adapting the evaluation method for sediment-hosted copper, volcanogenic massive sulfide, and porphyry copper deposits.

Finally, the Alaska Science Center and DGGS collaborated to release updates to the Alaska Resource Data File (ARDF), which include more recent production and exploration data for numerous active mines and exploration projects across the State. Updated geospatial versions of the database were also released in multiple formats.

\section{U.S. BUREAU OF LAND MANAGEMENT}

The U.S. Bureau of Land Management (BLM)-Alaska administers and adjudicates all Federal mining claim locations in Alaska, manages mining and other activities on BLM-managed lands, and continues its mission to convey land to the State of Alaska as well as Alaska Native village and regional corporations. Annually, the BLM conveys thousands of acres of land to the State and Native corporations under the authority of the Alaska Statehood Act and the Alaska Native Claims Settlement Act (ANCSA); most of the conveyed State land is open to claim location.

In 2017 the BLM completed an inventory of closed Federal mining claims that have been selected by the State of Alaska but not yet conveyed. The specific locations of these lands have not been readily available in recent years. To increase awareness of these claims, many of which are surrounded by active State claims, the closed-excluded-unconveyed claim locations were added to BLM-Alaska's Spatial Data Management System (SDMS) mapping website: https://sdms. ak.blm.gov/isdms/imf.jsp?site $=$ sdms.

The BLM continued with development of two resource management plans (RMPs) in 2017: the Bering Sea-Western Interior Plan and the Central Yukon Plan. To improve these planning efforts, the BLM supported USGS Alaska Minerals staff efforts to improve mineral potential related data and modeling. The GIS-based data produce more quantifiable estimates of where future exploration and development may take

See appendix $A$ and (or) navigate to http://akgeology.info for additional resources and information 
place. These RMPs will result in decisions concerning how BLM lands will be managed in the next decade or so.

The BLM managed 55 active mining Plans of Operations and 28 Notice-level operations primarily located along the Dalton Highway Utility Corridor, the Steese-Central area, and the Fortymile River area. Approved mining and exploration activities are almost all related to placer gold mining. Accordingly, BLM-Alaska initiated efforts to improve riparian and upland reclamation by coordinating reclamation demonstration projects and issuing internal policies to provide consensus and clarity on the reclamation standards. In 2017 the BLM issued instructional memoranda to BLM-field office staff regarding how to assess upland revegetation and wildlife rehabilitation and how to allow preliminary approval of older reclamation efforts. The BLM partnered with a mining operation on Wade Creek, near Jack Wade, to stabilize and reclaim a 1,000-foot-long stretch of historically-mined and heavily impacted stream.

A BLM national Reclamation and Sustainable Mineral Development Award, in the Small Operation category, was awarded to XII Caesars Gold, LLC and their placer gold mining operation on Uhler Creek, a tributary of the Fortymile River. This operation was recognized for their outstanding effort to promote habitat restoration and revegetation, and the award acknowledges their environmental stewardship success.

\section{DIVISION OF MINING, LAND \& WATER}

The Division of Mining, Land and Water (DMLW) manages mineral exploration and development on over 96 million acres of State land in Alaska. In addition, the Division reviews and approves the operation and reclamation plans for mining projects, including coal, on all State, Federal, and private lands in Alaska. In 2017 the Division's Large Mine Permitting Team coordinated hard rock mine permitting activities at Red Dog, Fort Knox, Pogo, Kensington, Greens Creek, and Nixon Fork.
Advanced exploration permitting activities were conducted at Graphite Creek on the Seward Peninsula, Donlin Gold in southwest Alaska, Pebble on the Alaska Peninsula, and the Palmer Project near Haines. DMLW manages mineral exploration and placer mining through the Application for Permits to Mine in Alaska (APMA). In 2017 there were 436 new applications or renewals of existing applications, a 2.5 percent increase from 2016. Of these applications, 326 were for placer mining and exploration, 51 were for hard rock exploration, and 59 were for suction dredging activities.

The State regulates coal mining through the Coal Mining Regulatory program. In addition to ongoing mining and reclamation at the active Usibelli Coal Mine, 2017 saw industry interest in developing high-rank coal south of Point Lay and at Herendeen Bay on the Alaska Peninsula. DMLW also began processing a new application for coal exploration in the Canyon Creek area south of Skwentna.

The State Abandoned Mine Lands program conducted reclamation at the Hydraulic Pit, an abandoned coal mine near Healy. The site was reclaimed using "geomorphic reclamation," a technique that attempts to recreate the original landforms and drainage patterns with the primary goal of bringing the area to a more natural condition and also reduces the need for future maintenance. For this work, the DMLW won the 2018 Western Regional Award from the Department of Interior's Office of Surface Mining for Outstanding Reclamation.

\section{DIVISION OF GEOLOGICAL \& GEOPHYSICAL SURVEYS}

Alaska Geologic Materials Center

The Alaska Geologic Materials Center (GMC), curated and operated by DGGS, is the State's largest and most comprehensive archive of geologic samples. The GMC houses drill core from numerous Alaska mineral prospects, DGGS rock samples, and the Alaska collections of the U.S. Geological Survey, the former U.S. Bureau of Mines, and other agencies. 


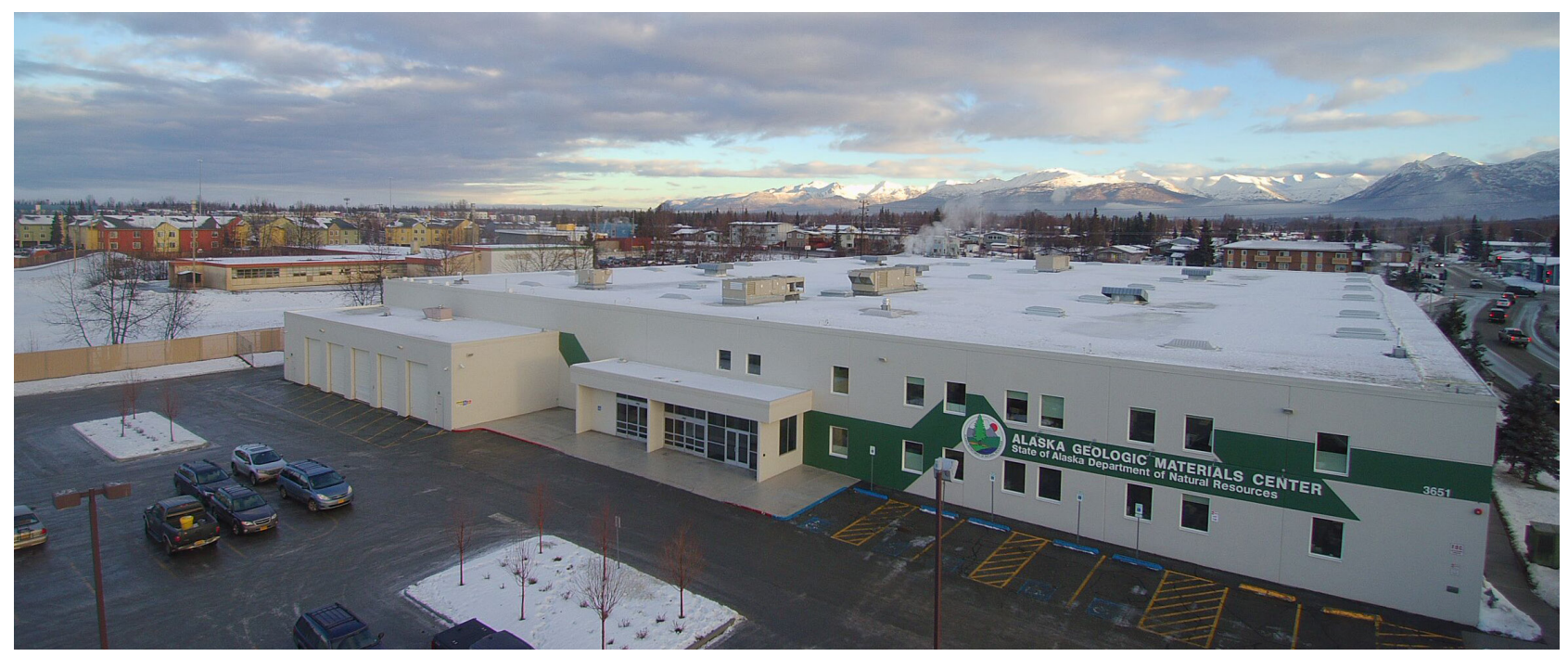

Photo 2. The Geologic Materials Center (GMC) facility in Anchorage, Alaska, makes available 617,000 representative feet of mineral-related core and cuttings and 354,000 linear feet of core donated by the mineral industry, among other surface and processed sample collections. Photo courtesy of Kurt Johnson, DGGS.

In 2017 the 100,000-square-foot facility at 3651 Penland Parkway in Anchorage (photo 2) reached half-full. The new facility features comfortable viewing areas with roller tables and high-lumen overhead lighting. The sample preparation room contains 14 " and 20 " slabbing saws. The GMC tracks just under 718,000 samples, including more than 38,000 core boxes from 275 prospects representing 2,242 boreholes. The browser-based search interface (maps.dggs.alaska. gov/gmc) allows users to build simple to complex queries through text- or map-based searches to find samples of interest.

Mineral industry clients donated significant volumes of core to the GMC in 2017. Major core donations were received from Cook Inlet Regional Inc. (Coffee Creek Beluga coal field) and Doyon, Limited (Reef Ridge prospect; photo 3). Donations from these two prospects added 2,300 core boxes representing 14 boreholes.

\section{Mineral Resources Section Activities}

The DGGS Mineral Resources Section uses its expertise in mineral deposit geology, geophysics, and geochemistry to evaluate State land for its potential to host undiscovered mineral resources (table 5). Section staff conduct geophysical surveys,

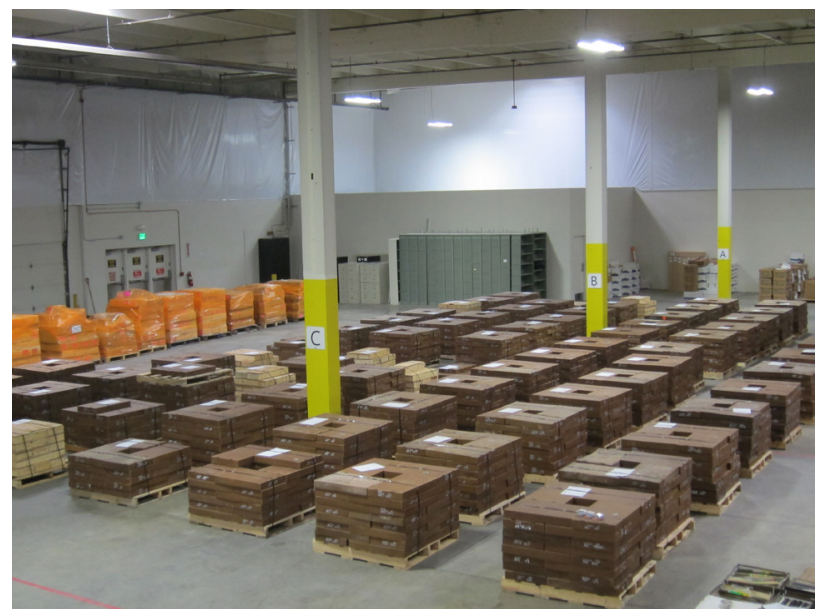

Photo 3. In 2017 the GMC received donations of core from Doyon, Limited's zinc oxide Reef Ridge prospect in western Alaska and Cook Inlet Regional Inc.'s exploration for coalbed methane at Coffee Creek near Beluga, Alaska. Photo courtesy of Kurt Johnson, DGGS.

geologic mapping, mineral-resource assessments, and ore deposit research; they also track mineral industry exploration and discoveries, development, and production. Additionally, the Section's expertise and knowledge are sought to review other Departmental actions including State land selection conveyance prioritization, land-use plans, land disposal actions, review of Federal actions, and infrastructure planning. The geophysical, 
Table 5. New mineral resource-related DGGS publications in 2017.

Geologic maps, reports, and geochemical data

Alaska Geochemistry online database and web map - http://maps.dggs.alaska.gov/geochem

Tok River area geologic map - http://doi.org/10.14509/29722

Tok River area geochemical data - http://doi.org/10.14509/29727

Richardson Mining District geochemical data - http://doi.org/10.14509/29779

Northeastern Tanacross area geochemical data - http://doi.org/10.14509/29778

Canwell Prospect geochemical data - http://doi.org/10.14509/29780

Western Alaska Range and Talkeetna Mountains U-Pb zircon data - http://doi.org/10.14509/29717

Mount Hayes and Talkeetna Mountains Ar/Ar age data - http://doi.org/10.14509/29699

Seward Highway-Whittier area geochemical data - http://doi.org/10.14509/29725

Whittier area Ar/Ar age data - http://doi.org/10.14509/29721

Alaska's mineral industry 2016 (report) - http://doi.org/10.14509/29748

Alaska's mineral industry 2016 (presentation) - http://doi.org/10.14509/29711

geological, and resource surveys conducted by the Mineral Resources Section not only inventory the potential for mineral resources, but add value to the State's current and future revenue.

Since 1993 the data products of the Airborne Geophysical/Geological Mineral Inventory (AGGMI) program have been an important component of successful resource-exploration programs; products have contributed to the private-sector discovery of more than 22 million ounces of gold resources in the Salcha River-Pogo and Livengood areas (figure 2). State budget cuts impacted the AGGMI program, resulting in the loss of a permanent staff position in the Mineral Resources Section and its annual funding for data collection and publication. New geophysical surveys now rely on ad-hoc funding from external sources (table 6) or the State of Alaska’s capital budget.

\section{Geophysical Datasets}

In 2017 DGGS managed the acquisition of a USGS-funded 5,200-square-mile aeromagnetic survey over the Porcupine area of northeastern Alaska. DGGS geophysicists also worked on interpretation of resistivity models for the Goldstream and Yukon Crossing airborne electromagnetic and magnetic surveys. Porcupine, Goldstream, and Yukon Crossing data will be released in 2018. DGGS continues to archive and reformat prior surveys to make those data accessible online. Numerous prior surveys are scheduled for online re-release in 2018, and the entire "as is" geophysical data archive is now available for a fixed price and fast delivery.

\section{Geologic Mapping and Geochemical} Sampling

In 2017 DGGS Mineral Resource geologists published 480 square miles of detailed geologic mapping for the Tok River area of the eastern Alaska Range. The purpose of this 2-year project was to evaluate the mineral-resource potential of the Tok River area; adjacent lands host volcanogenic massive sulfide-type base-metal deposits, copper-gold skarns, and structurally controlled, gold-bearing veins. Within the map area there are intrusion-related copper-gold prospects, stratiform base-metal prospects of uncertain origin, and placer gold occurrences. DGGS documented 20 mineral occurrences not previously part of the public record. Following publication of the Statefunded airborne geophysical survey and geochemical datasets, industry staked about 76,500 acres of 


\section{Modern Airborne Geophysical Data Coverage}

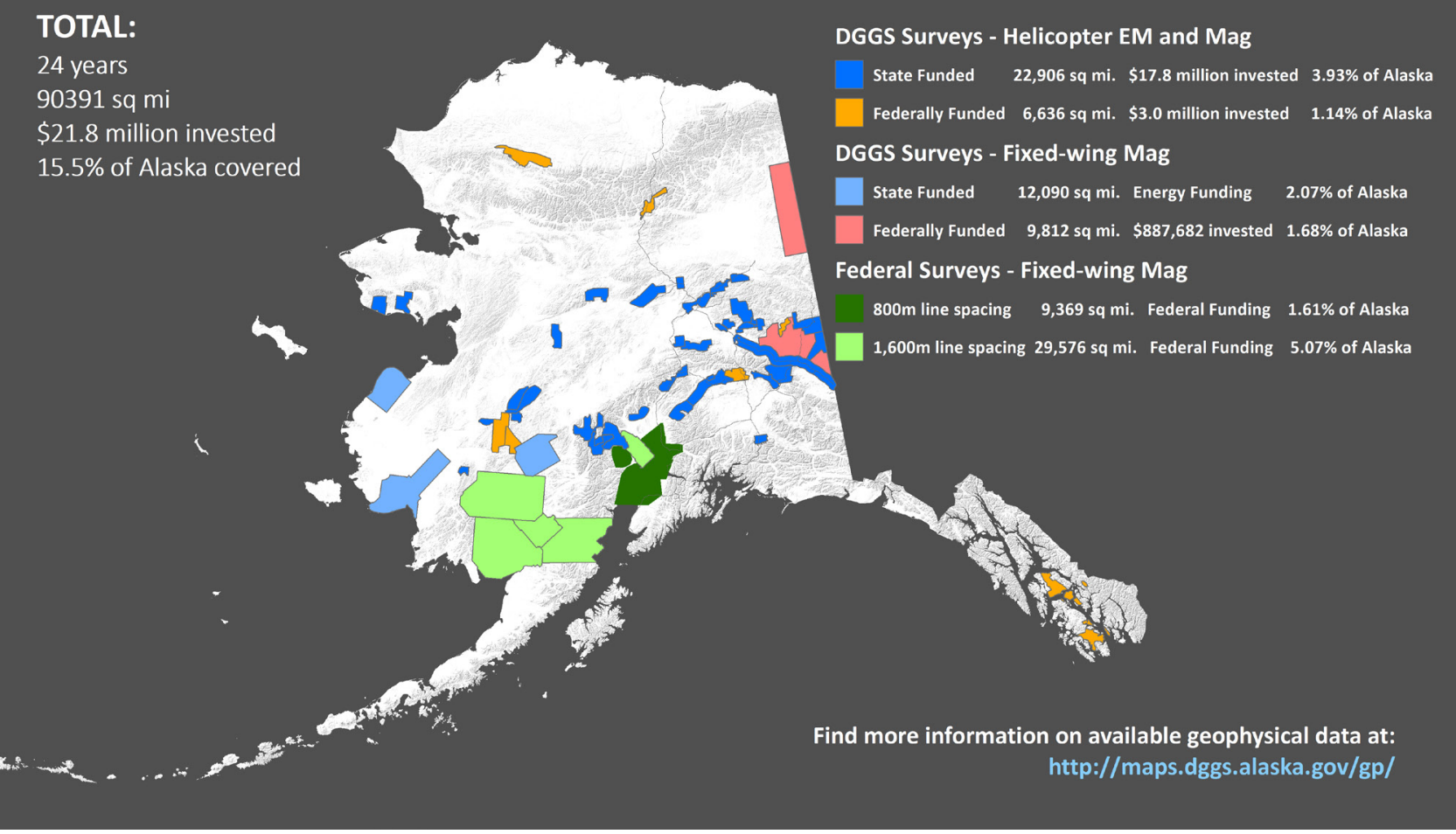

Figure 2. Modern airborne geophysical data coverage of Alaska, managed by Alaska Division of Geological \& Geophysical Surveys and the U.S. Geological Survey over the past 24 years. Survey data are available from the Division's website: http://maps.dggs.alaska.gov/gp/.

claims on State land in the area, which increased State revenue through mining claim fees.

In 2017 DGGS Mineral Resource geologists completed fieldwork for year one of a two-year geologic mapping and geochemical sampling project covering 520 square miles in the northeastern Tanacross Quadrangle. The purpose of this project is to evaluate the area's mineral-resource potential and to create a geologic map to help guide industry exploration efforts (photo 4). The area contains known porphyry copper-goldmolybdenum systems thought to be spatially associated with high-angle fault systems, many of which can be directly identified in DGGS airborne geophysical surveys of the area.
DGGS Mineral Resource geologists also completed the first year of fieldwork for a twoyear geologic mapping and geochemical sampling project in the Richardson-Uncle Sam gold exploration area northwest of Delta Junction. The 2017 portion of this mapping project covered an area of 250 square miles, which utilized DGGS's East Richardson geophysical survey to facilitate mapping in this heavily vegetated area with abundant loess and sand dune cover. The purpose of this project is to integrate geological, geophysical, and mining industry datasets to create an improved geologic map that will guide exploration and help to determine the area's mineral-resource potential, based on known mineral systems and proximity to the Pogo gold mine.

Photo 4, opposite page. The DGGS Mineral Resources team mapped the Taurus and Bluff Cu-Mo-Au porphyry deposits during the first of a two-year project in the northeast Tanacross area to gain a better understanding of the region's geology and mineral deposits. Photo courtesy of Evan Twelker, DGGS. 
Table 6. DGGS-managed, Federally funded detailed airborne geophysical survey work as of December 2017.

\begin{tabular}{|c|c|c|}
\hline Survey Area & Survey Size (square miles) & Resulting Products \\
\hline Wrangell/Stikine ${ }^{b}$ & 1,111 & Airborne geophysical survey \\
\hline Koyukuk/Wiseman & 533 & Airborne geophysical survey \\
\hline Ketchikanc & 805 & Airborne geophysical survey \\
\hline Aniak & 1,240 & Airborne geophysical survey \\
\hline Delta River & 603 & Airborne geophysical survey \\
\hline Sleetmute & 641 & Airborne geophysical survey \\
\hline $\begin{array}{l}\text { Howard Pass-Misheguk } \\
\text { Mountain }\end{array}$ & 1,447 & Airborne geophysical survey \\
\hline Western Fortymile & 250 & Airborne geophysical survey \\
\hline Tanacross $^{d}$ & 4,550 & Airborne geophysical survey \\
\hline Porcupine ${ }^{d}$ & 5,382 & Airborne geophysical survey \\
\hline Total $\$ 3.9$ million & 16,562 & $2.82 \%$ of Alaska's total area \\
\hline
\end{tabular}

aprojects funded mainly by U.S. Bureau of Land Management with contributions from DGGS, local and State governments, and private corporations. Projects concentrate mainly on Federal land. Data are released through DGGS.

bMajor funding provided by BLM and the City of Wrangell.

‘Major funding provided by BLM and Ketchikan Gateway Borough. Sealaska Corp., Alaska State Mental Health Land Trust Office, the City of Coffman Cove, and the City of Thorne Bay also contributed funds. Sealaska Corp. also contributed previously acquired geophysical data.

${ }^{\mathrm{d}}$ Funding provided by U.S. Geological Survey.

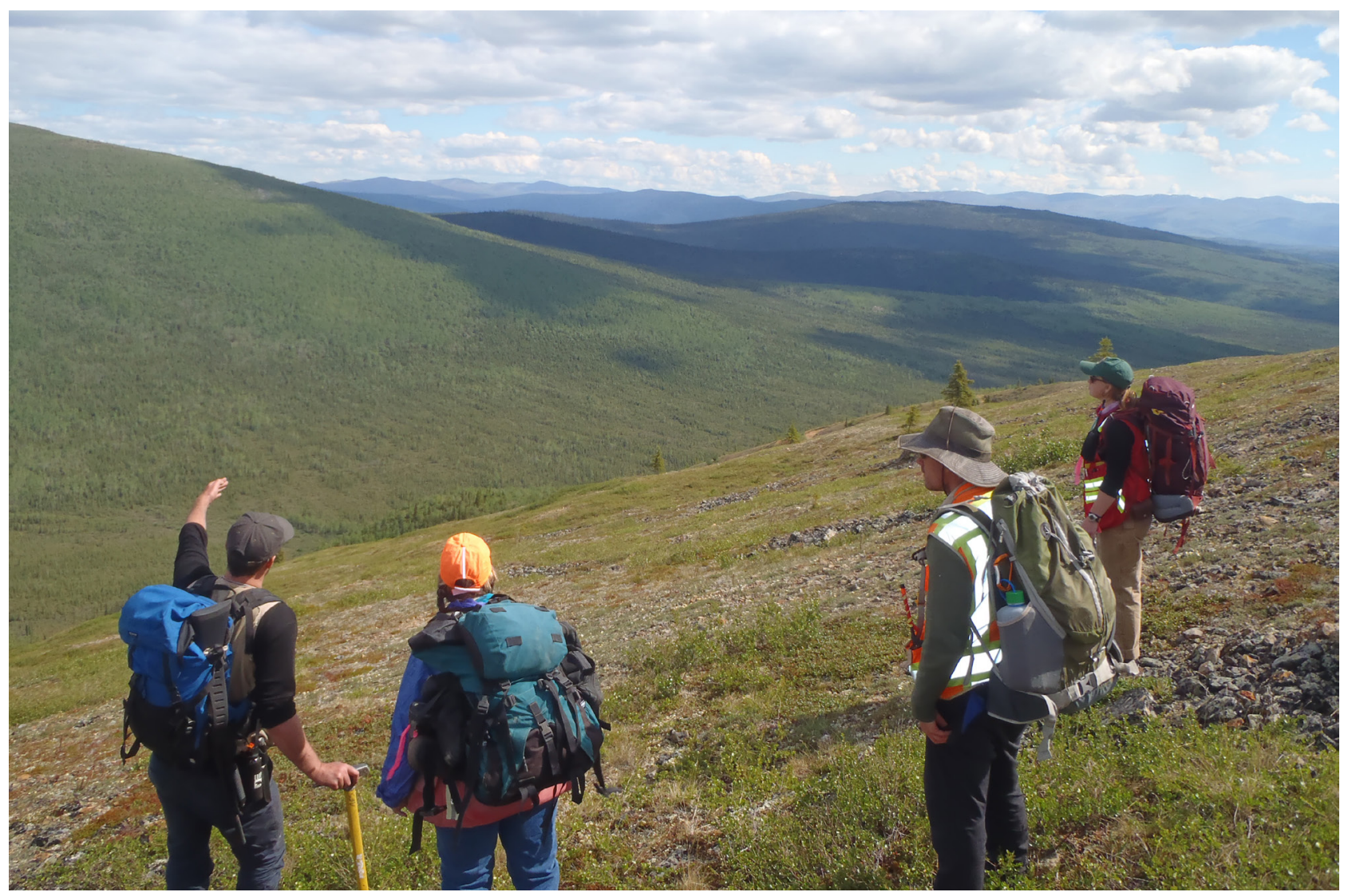




\section{EXPLORATION}

\section{Alaska exploration spending increased significantly (105 percent) for the first time in four years, rising to $\$ \mathbf{1 2 0 . 8}$ million in 2017}

(figures 3 and 4) and outpacing the 15 percent growth in mineral exploration spending worldwide. Alaska's share of the $\$ 8.4$ billion global exploration budget was 1.4 percent. $^{6}$ The exploration sector's recovery, which began in 2016, was fueled by increased metal prices and more available financing; however, S\&P Global Market Intelligence noted that there is still substantial room for improvement, especially in the context of record exploration spending in Alaska and higher metal prices seen in 2011 and 2012. Alaska exploration spending by commodity and deposit type also followed global trends, with growth in gold exploration outpacing increases in exploration spending for base metals (copper, nickel, zinc, and lead) and other commodities (table 7; figure 5).

Fifty-seven metallic mineral exploration projects, some managed by the same company, reported activity in 2017. Advanced and early-stage exploration played a much bigger role in 2017 exploration with the largest share of exploration spending on early-stage projects. The share of exploration conducted by Alaska's five operating metal mines fell to 29 percent of the statewide total in 2017, even though near-mine exploration spending rose to $\$ 35.4$ million from $\$ 28.6$ million in 2016. Eleven development and advancedstage exploration projects spent more than $\$ 40.2$ million, one-third of the statewide exploration total, with the remainder ( $\$ 45.1$ million) spent by early-stage exploration projects. Many of Alaska's advanced exploration and development projects have reached a stage of decreased exploration investment, focusing instead on optimization

\section{Exploration Highlights}

Drill data at Teck Alaska Inc.'s Aktigiruq deposit suggest a large undeveloped zinc target (pg. 16)

Trilogy and South 32 doubled the size of the Bornite footprint, which now measures 5,000 by 8,000 feet (pg. 23)

A new conglomerate ore host was identified at the Golden Zone property (pg. 37)

The first-ever drill hole at Constantine's Nunatak AG Zone prospect encountered high-grade mineralization (pg. 49)

studies, permitting, or the search for additional financing. Excluding the operating mines, 16 projects spent more than $\$ 1$ million, up significantly from six projects in 2016. As in 2016, an additional 14 projects individually spent more than $\$ 100,000$.

In keeping with the turnaround in exploration spending, numbers of claims and claimed acreage increased significantly in 2017, particularly for new 160-acre State claims and new 20 -acre Federal claims. The total area of the State covered by mining claims and prospecting sites in 2017 increased by nearly 16 percent to almost three million acres. New claim and prospect site staking on State and Federal lands increased sharply over 2016, a 230 percent increase in terms of acres newly staked.

\section{NORTHERN REGION}

\section{Aktigiruq}

Teck Alaska Inc. continued to explore for sediment-hosted massive sulfides on their Noatak project, which includes the Anarraaq and Aktigiruq deposits, about 8 miles northwest of its Red Dog mine in northwest Alaska. Ongoing

'S\&P Global Market Intelligence, 2018, World Exploration Trends: A special report from S\&P Global Market Intelligence for the PDAC International Convention, 12 p. 


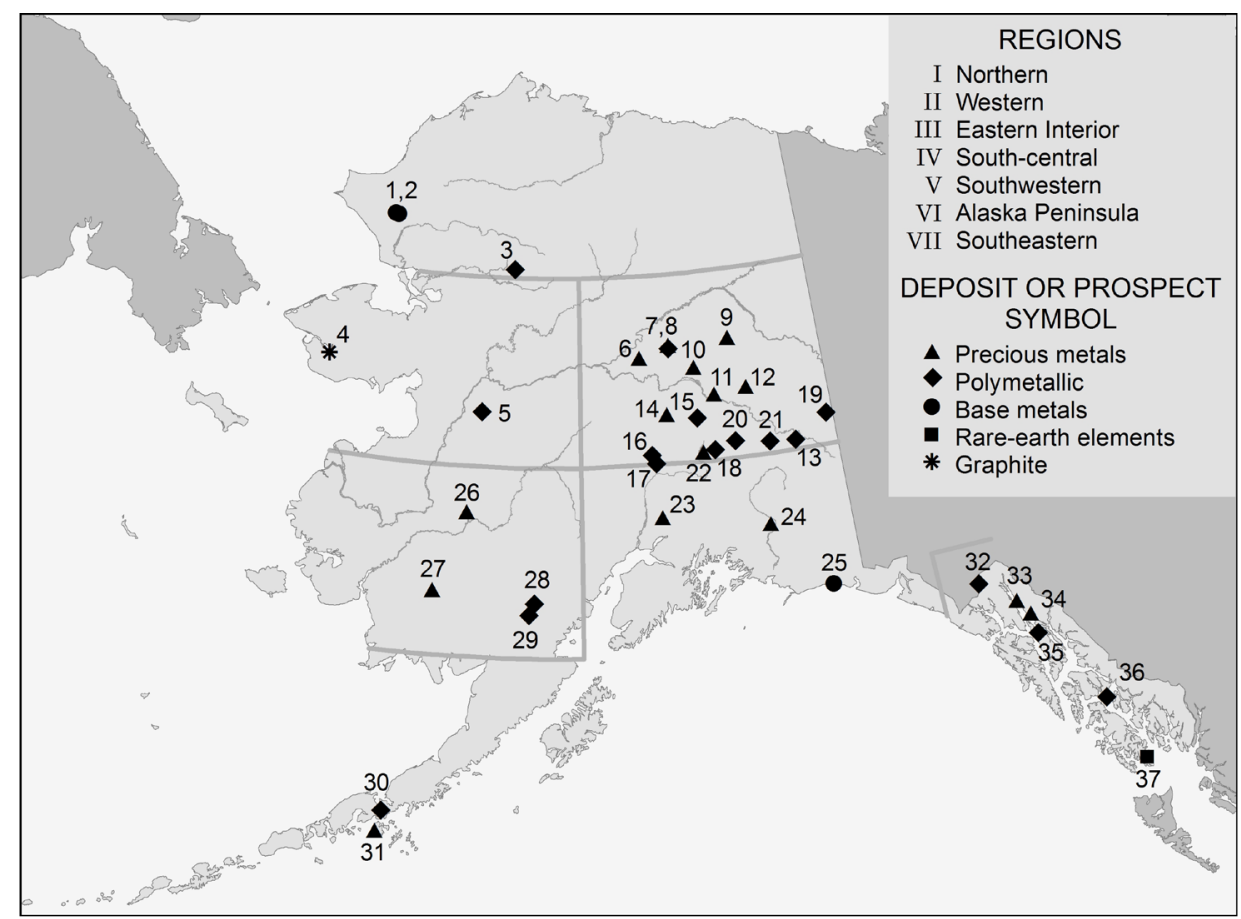

Figure 3. Selected exploration projects in Alaska, 2017.

\section{Exploration}

\section{Northern Region}

1. Lik-Solitario Zinc Corp. / Teck Resources

2. Noatak-Teck Alaska Inc.

3. Upper Kobuk (Arctic and Bornite)Trilogy Metals Inc.

\section{Western Region}

4. Graphite Creek-Graphite One Resources

5. Round Top-Western Alaska Copper \& Gold

\section{Eastern Interior Region}

6. Elephant Mountain-Endurance Gold Corporation

7. Livengood-International Tower Hill Mines Ltd.

8. Shorty Creek-Freegold Ventures Ltd.

9. Circle-area claims-Kinross Gold Corp.

10. Fairbanks District

a. Fort Knox and district-Kinross Gold Corp.

b. Golden Summit-Freegold Ventures Ltd.

11. Richardson-Northern Empire Resources Corp.
12. Goodpaster Mining District

a. Pogo mine area-Sumitomo Metal Mining Pogo LLC

b. Skippy and Fog-Stone Boy Inc.

c. Tibbs-Tectonic Resources LLC

13. Peak-Peak Gold LLC

14. Liberty Bell-Millrock Resources Inc.

15. Red Mountain-White Rock Minerals Ltd.

16. Golden Zone-Avidian Gold Inc.

17. Honolulu-Honolulu Prospect Corp.

18. Alaska Range Project-PolarX Ltd. 19. Tanacross Project-Kenorland Minerals

20. Emerick-Northridge Exploration

21. Delta District

a. Delta VMS-Agnico Eagle Mines Ltd.

b. Paxson Project-Rhyolite Resources Ltd.

22. Valdez Creek Lode-Valdez Creek Mining LLC

\section{Southcentral Region}

23. Lucky Shot-Alaska Gold Torrent LLC

24. Opal-Ben Porterfield

25. Icy Cape-Alaska Mental Health

Trust Land Office

\section{Southwestern Region}

26. Donlin Gold project-Donlin Gold LLC

27. Luna-Quicksilver-Kisa-Riversgold Ltd.

28. Pebble-The Pebble Limited

Partnership

29. Groundhog-Chuchuna Minerals

Co. / Quaterra Resources Inc.

\section{Alaska Peninsula Region}

30. Pyramid/San Diego Bay-

CopperBank Resources Corp.

31. Unga-Popov-Redstar Gold Corp.

\section{Southeastern Region}

32. Palmer-Constantine Metal

Resources Ltd.

33. Kensington/Jualin-Coeur Alaska Inc.

34. Herbert Gold-Grand Portage Resources Ltd.

35. Greens Creek Mine-Hecla Mining Company

36. Zarembo Island-Zarembo Minerals Co. LLC

37. Bokan Mountain/Dotson RidgeUcore Rare Metals Inc. 
investments in second-generation structural and stratigraphic mapping, deep-penetrating airborne Helitem, and footprint geochemistry have refined and improved Teck's integrated targeting models. Teck's Anarraaq deposit is an elongate, lens-shaped massive sulfide body that is 3,280 feet long, 1,640 feet wide, and up to 262 feet thick. It has an inferred resource of 21,428,712 tons grading 14.4 percent zinc, 4.2 percent lead, and 2.1 ounces of silver per ton (appendix D).

Teck's regional exploration in 2017 focused on Aktigiruq, a significant high-grade, sediment-hosted zinc-lead-silver deposit located on 100 percent Teck-owned State of Alaska mining claims 1.4 miles north of the Anarraaq deposit.

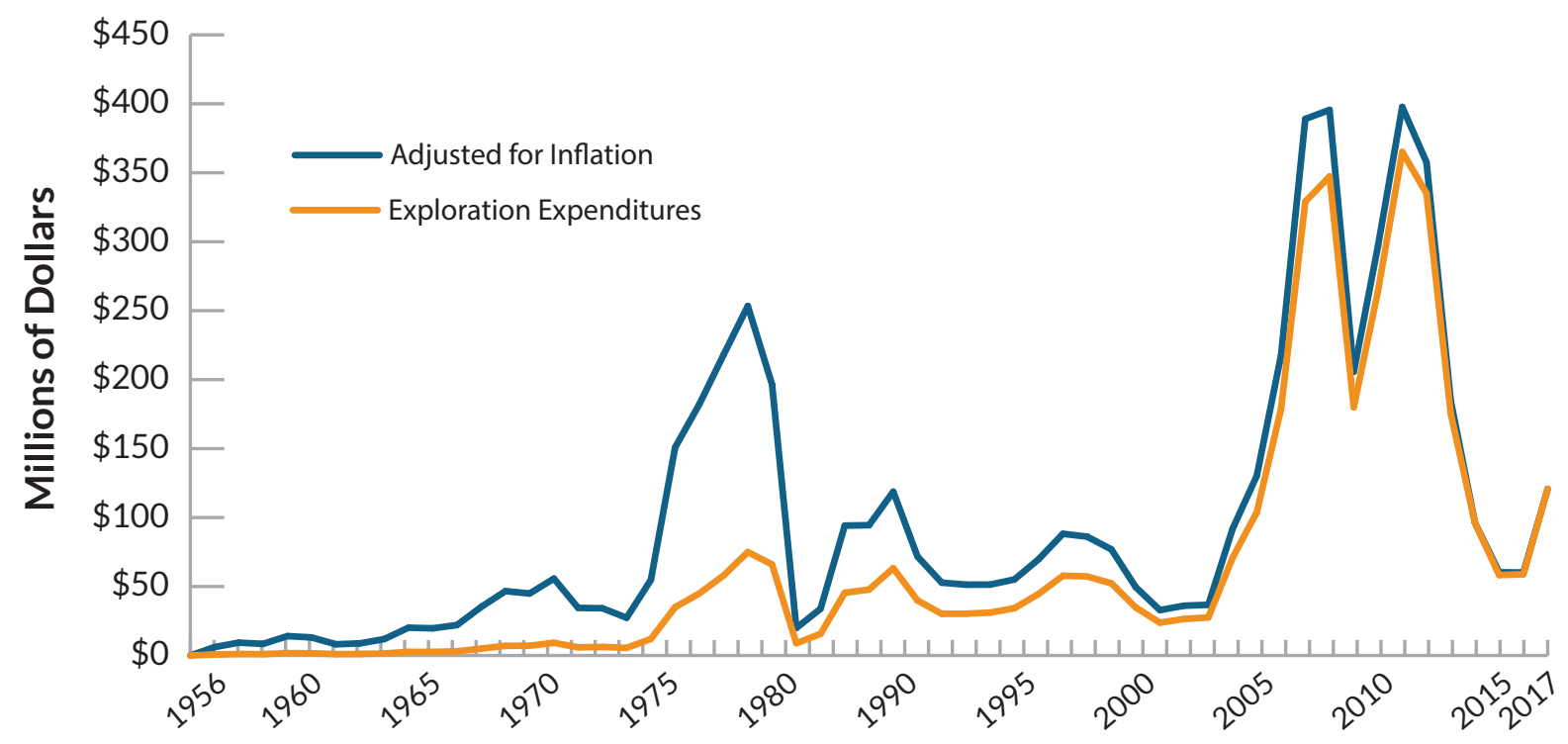

Figure 4. Alaska mineral exploration expenditures, 1956-2017. Blue line is adjusted for inflation to 2017 dollars.

\section{Exploration Expenditures by Deposit Type}

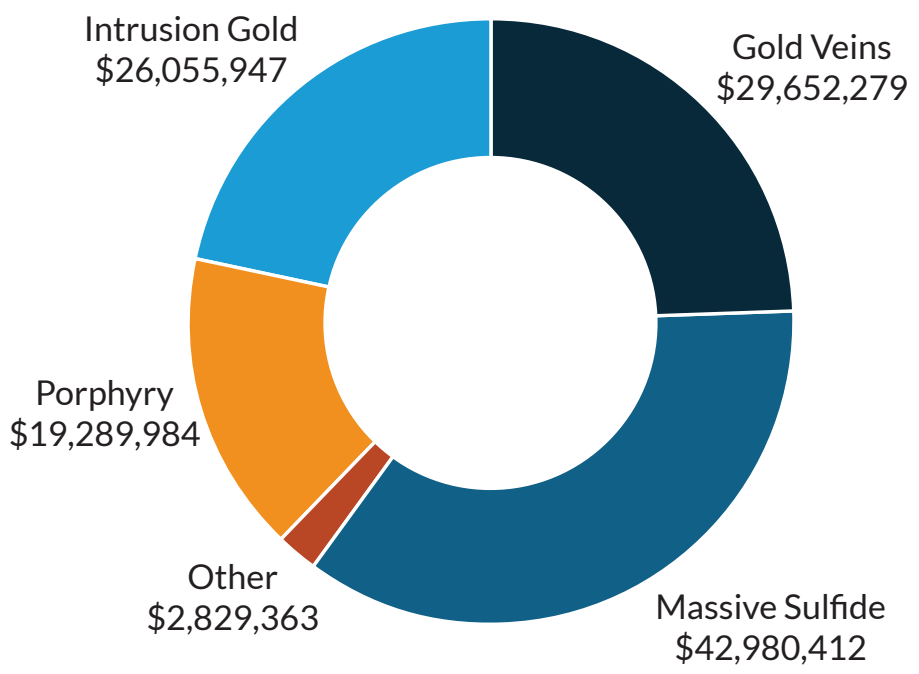

\footnotetext{
Porphyry copper-gold-(molybdenum)

Intrusion-related gold (Fort Knox,

Donlin Creek types)

Gold-quartz veins (epithermal

and mosothermal, Pogo-type)

Massive sulfide (VMS, Sedex, base-metal-rich)

Other: REEs, PGE-Ni-Cu, magnetite sands, coal, graphite, and metasedimentary-hosted gold (not including placer gold)
}

Figure 5. Exploration expenditures by deposit type, 2017. 
The Aktigiruq deposit was first drilled in 1999 , and prior to the 2017 drill program, a total of 25 wide-spaced diamond drill holes intersected mineralization at Aktigiruq over an area of approximately 10,000 feet by 5,000 feet (figure 6). As of February 2017, 29 drill holes for a total of 78,593 feet were completed at a nominal 1150 - by 1150 -foot drill spacing. Although this spacing is not yet sufficient to estimate an official mineral resource, Teck stated their drill data suggest an exploration target for Aktigiruq in the range of 88-165 million tons of mineralization at a grade of 16-18 percent combined zinc plus lead. If continued drilling confirms this, Aktigiruq would be one of the largest undeveloped zinc deposits in the world, comparable in total size to all past production and current reserves at Red Dog mine. In 2017 Teck conducted a \$16 million, helicopter-supported drill program to test the internal continuity and lateral extents of the Aktigiruq deposit, which includes approximately 59,055 feet in 16 to 20 planned drill holes,

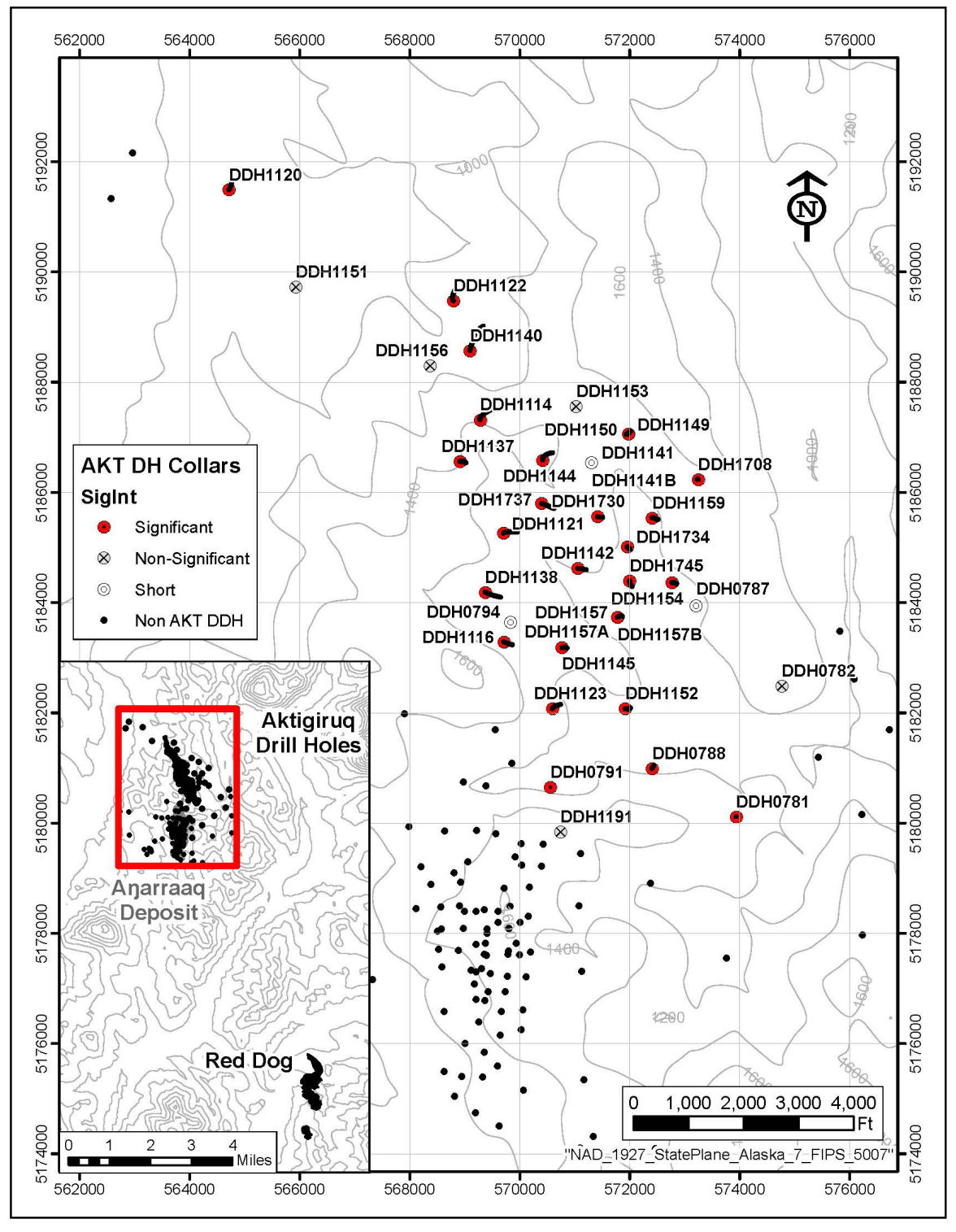

Figure 6. Aktigiruq pre-2017 drill hole location map. Figure source: Teck Resources Limited; last accessed October 22, 2018; https://www.teck.com/ news/news-releases/2017/teck-increases-red-dog-production-guidance-andupdates-exploration-results-in-the-red-dog-district- with 10 holes completed and 32,356 feet drilled as of the end of August 2017. Mineralization is located at depths of between 1,312 and 3,280 feet below surface. In September 2017, Teck released results from two holes drilled at Aktigiruq in 2016: diamond drill hole (DDH) 1737 with 177 feet grading 16.8 percent zinc, 3.63 percent lead, and 0.048 ounce of silver per ton and DDH 1745 with 44.6 feet grading 19.68 percent zinc, 5.54 percent lead, and 0.112 ounce of silver per ton. Mineralization remains open in several directions and further drilling is planned, both to test the internal continuity of mineralization as well as the limits of the hydrothermal system.

\section{Lik}

Solitario Zinc Corp. completed acquisition of $\mathrm{Zazu}$ Metals Corp., taking over Zazu's 50-percent ownership of the Lik zinc-lead-silver sediment-hosted massive sulfide deposit northwest of Red Dog mine in northwest Alaska 
Table 7. Reported exploration expenditures in Alaska by commodity, 1981-2017. Exploration expenditures were estimated for eight projects using their reported work. Exploration expenditures were estimated for four additional projects using their reported employment or drilling footage, and a project-cost ratio averaged from 32 and 18 projects, respectively, with reported, complete data.

\begin{tabular}{|c|c|c|c|c|c|c|c|}
\hline & Base metals & Polymetallic ${ }^{a}$ & $\begin{array}{r}\text { Precious } \\
\text { metals }^{\mathbf{b}}\end{array}$ & $\begin{array}{c}\text { Industrial } \\
\text { minerals }\end{array}$ & Coal and peat & Otherc & Total \\
\hline 1981 & $\$ 28,262,200$ & -- & $\$ 35,273,200$ & $\$ 10,300,000$ & $\$ 2,341,000$ & $\$ 127,000$ & $\$ 76,303,400$ \\
\hline 1982 & $31,757,900$ & & $10,944,100$ & & $2,900,000$ & 15,300 & $45,617,300$ \\
\hline 1983 & $9,758,760$ & -- & $20,897,555$ & $2,068,300$ & $1,338,454$ & 70,000 & $34,133,069$ \\
\hline 1984 & $4,720,596$ & -- & $14,948,554$ & 270,000 & $2,065,000$ & 279,500 & $22,283,650$ \\
\hline 1985 & $2,397,600$ & & $6,482,400$ & & 270,000 & -- & $9,150,000$ \\
\hline 1986 & $1,847,660$ & -- & $6,107,084$ & 170,000 & 790,000 & -- & $8,914,744$ \\
\hline 1987 & $2,523,350$ & -- & $11,743,711$ & 286,000 & $1,150,000$ & 31,000 & $15,734,061$ \\
\hline 1988 & $1,208,000$ & -- & $41,370,600$ & 160,200 & $2,730,000$ & -- & $45,468,800$ \\
\hline 1989 & $3,503,000$ & -- & $43,205,300$ & 125,000 & 924,296 & 5,000 & $47,762,596$ \\
\hline 1990 & $5,282,200$ & -- & $57,185,394$ & 370,000 & 321,000 & 97,000 & $63,255,594$ \\
\hline 1991 & $4,789,500$ & -- & $34,422,039$ & 92,000 & 603,000 & 2,000 & $39,908,539$ \\
\hline 1992 & $1,116,000$ & $\$ 3,560,000$ & $25,083,000$ & 25,000 & 425,000 & 0 & $30,209,000$ \\
\hline 1993 & 910,000 & $5,676,743$ & $23,382,246$ & 163,500 & 0 & 125,000 & $30,257,489$ \\
\hline 1994 & 600,000 & $8,099,054$ & $18,815,560$ & 225,000 & $2,554,000$ & 810,000 & $31,103,614$ \\
\hline 1995 & $2,770,000$ & $10,550,000$ & $20,883,100$ & 100,000 & 0 & 3,000 & $34,306,100$ \\
\hline 1996 & $1,100,000$ & $11,983,364$ & $31,238,600$ & 400,000 & 0 & 0 & $44,721,964$ \\
\hline 1997 & $1,700,000$ & $22,347,000$ & $32,960,500$ & 80,000 & 720,000 & 0 & $57,807,500$ \\
\hline 1998 & $1,000,000$ & $13,727,000$ & $42,441,000$ & 12,000 & 87,000 & 0 & $57,267,000$ \\
\hline 1999 & $3,869,000$ & $3,168,000$ & $44,891,000$ & 1,000 & 0 & 410,000 & $52,339,000$ \\
\hline 2000 & $8,545,000$ & $3,933,000$ & $21,579,000$ & 58,500 & 0 & 736,100 & $34,851,600$ \\
\hline 2001 & $4,810,000$ & $1,977,000$ & $15,820,000$ & 50,000 & 10,000 & $1,106,000$ & $23,773,000$ \\
\hline 2002 & $1,700,000$ & $5,162,000$ & $17,342,000$ & 185,000 & 0 & $2,113,000$ & $26,502,000$ \\
\hline 2003 & 262,000 & $7,081,000$ & $19,726,000$ & 0 & 0 & 533,000 & $27,602,000$ \\
\hline 2004 & $3,100,000$ & $40,237,000$ & $26,954,000$ & 213,000 & 50,000 & 258,000 & $70,812,000$ \\
\hline 2005 & $1,764,000$ & $54,271,000$ & $46,255,000$ & 142,000 & 0 & $1,463,000$ & $103,895,000$ \\
\hline 2006 & $5,069,000$ & $81,073,000$ & $89,793,000$ & 20,000 & $2,394,000$ & 580,000 & $178,929,000$ \\
\hline 2007 & $38,888,000$ & $123,487,500$ & $155,601,400$ & 42,500 & $7,675,000$ & $3,447,000$ & $329,141,400$ \\
\hline 2008 & $30,116,000$ & $163,030,000$ & $134,885,000$ & 0 & 0 & $19,238,000$ & $347,269,000$ \\
\hline 2009 & $3,862,715$ & $85,871,529$ & $84,020,531$ & 17,850 & 0 & $6,193,518$ & $179,966,143$ \\
\hline 2010 & $6,392,519$ & $122,955,321$ & $125,364,382$ & 19,000 & $6,520,200$ & $3,104,199$ & $264,355,621$ \\
\hline 2011 & $7,730,891$ & $160,880,974$ & $186,255,005$ & -- & $3,250,000$ & $6,962,325$ & $365,079,195$ \\
\hline 2012 & $18,161,211$ & $150,339,009$ & $152,444,311$ & -- & W & $14,129,838$ & $335,074,369$ \\
\hline 2013 & $8,122,810$ & $103,524,782$ & $60,977,949$ & 22,762 & W & $2,840,713$ & $175,489,016$ \\
\hline 2014 & $8,310,433$ & $29,836,240$ & $51,759,541$ & 32,221 & W & $6,300,413$ & $96,238,848$ \\
\hline 2015 & $6,199,064$ & $25,171,955$ & $26,907,877$ & -- & -- & -- & $58,278,896$ \\
\hline 2016 & $7,820,283$ & $25,295,705$ & $24,857,804$ & -- & -- & 912,510 & $58,886,302$ \\
\hline 2017 & $16,207,528$ & $48,325,468$ & $53,605,626$ & -- & W & $2,669,363$ & $120,807,985$ \\
\hline Total & $\$ 286,177,220$ & $\$ 1,311,563,644$ & $\$ 1,816,423,369$ & $\$ 15,650,833$ & $\$ 39,117,950$ & $\$ 74,561,779$ & $\$ 3,543,494,795$ \\
\hline
\end{tabular}

aPolymetallic deposits considered a separate category for the first time in 1992.

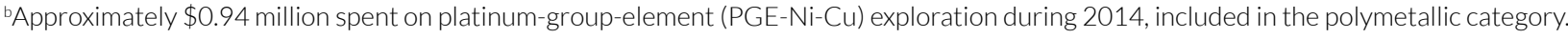
Prior to 2013, PGE exploration was included in the precious metal exploration total.

Includes rare-earth elements, magnetite sands, and graphite.

$\mathrm{N} / \mathrm{A}=$ Not available

- - = Not reported

W = Withheld; data included in "Other" column 
in July 2017. The other 50-percent is held by Teck Resources. Lik hosts two zinc deposits separated by a fault. Lik South has an indicated resource of 20.66 million tons grading 8.08 percent zinc, 2.62 percent lead, and 1.54 ounces of silver per ton, plus an inferred resource of 1.36 million tons grading 6.80 percent zinc, 2.12 percent lead, and 1.0 ounce of silver per ton. Lik North contains 5.71 million tons of inferred resource averaging 9.65 percent zinc, 3.25 percent lead, and 1.5 ounces of silver per ton (appendix D). In August 2017, Solitario initiated metallurgical testing to determine the potential to recover silver at Lik.

Table 8. Summary of claim activity, 1991-2017.

\begin{tabular}{|c|c|c|c|c|c|c|c|c|c|}
\hline \multirow[b]{2}{*}{ Year $^{\mathrm{a}}$} & \multicolumn{4}{|c|}{ State Claims } & \multicolumn{2}{|c|}{$\begin{array}{c}\text { State } \\
\text { Prospecting } \\
\text { Sites (160 acres) }\end{array}$} & \multicolumn{2}{|c|}{$\begin{array}{r}\text { Federal Claims } \\
\text { (20 acre sites) }\end{array}$} & \multirow{2}{*}{$\begin{array}{c}\text { Total } \\
\text { Acreage } \\
\text { Total }\end{array}$} \\
\hline & $\begin{array}{c}\text { New (Active) } \\
40 \text { acre }^{b}\end{array}$ & $\begin{array}{c}\text { New (Active) } \\
160 \text { acre }\end{array}$ & $\begin{array}{c}\text { Total (Active) } \\
40 \text { acre }^{b}\end{array}$ & $\begin{array}{c}\text { Total (Active) } \\
160 \text { acre }\end{array}$ & New & Total & New & Total & \\
\hline 1991 & 3,277 & 0 & 37,862 & 0 & 747 & 1,723 & 1,299 & 23,222 & $2,254,600$ \\
\hline 1992 & 2,640 & 0 & 36,250 & 0 & 454 & 1,472 & 695 & 20,254 & $2,090,600$ \\
\hline 1993 & 2,120 & 0 & 34,340 & 0 & 1,412 & 2,259 & 601 & 9,298 & $1,921,000$ \\
\hline 1994 & 4,057 & 0 & 34,400 & 0 & 802 & 2,378 & 341 & 8,495 & $1,926,380$ \\
\hline 1995 & 4,512 & 0 & 30,464 & 0 & 1,030 & 2,725 & 376 & 7,766 & $1,809,880$ \\
\hline 1996 & 9,489 & 0 & 36,602 & 0 & 2,082 & 3,687 & 681 & 9,346 & $2,240,920$ \\
\hline 1997 & 8,678 & 0 & 42,836 & 0 & 2,480 & 5,305 & 1,872 & 11,320 & $2,788,640$ \\
\hline 1998 & 9,786 & 0 & 49,816 & 0 & 3,194 & 7,148 & 427 & 11,033 & $3,356,980$ \\
\hline 1999 & 11,978 & 0 & 56,107 & 0 & 1,755 & 7,600 & 308 & 10,176 & $3,663,800$ \\
\hline 2000 & 4,560 & 614 & 54,393 & 614 & 1,143 & 5,675 & 523 & 7,805 & $3,338,060$ \\
\hline 2001 & 858 & 907 & 49,627 & 1,503 & 27 & 3,091 & 464 & 8,248 & $2,885,080$ \\
\hline 2002 & 745 & 826 & 44,056 & 2,179 & 61 & 2,138 & 261 & 8,100 & $2,614,960$ \\
\hline 2003 & 856 & 2,603 & 38,076 & 4,387 & 101 & 1,857 & 676 & 8,424 & $2,690,560$ \\
\hline 2004 & 1,070 & 3,533 & 34,380 & 7,719 & 59 & 1,484 & 66 & 8,313 & $3,013,940$ \\
\hline 2005 & 806 & 4,502 & 34,066 & 11,551 & 128 & 1,612 & 411 & 7,826 & $3,625,240$ \\
\hline 2006 & 1,111 & 5,747 & 33,864 & 16,249 & 103 & 1,646 & 457 & 8,068 & $4,379,120$ \\
\hline 2007 & 576 & 6,031 & 31,305 & 20,208 & 57 & 1,625 & 933 & 8,872 & $4,922,920$ \\
\hline 2008 & 1,333 & 2,565 & 23,033 & 13,519 & 24 & 651 & 3,001 & 11,732 & $3,423,160$ \\
\hline 2009 & 1,142 & 2,793 & 24,340 & 16,381 & 40 & 335 & 1,057 & 10,431 & $3,856,780$ \\
\hline 2010 & 1,446 & 6,132 & 24,805 & 20,389 & 88 & 441 & 332 & 8,413 & $4,493,260$ \\
\hline 2011 & 1,932 & 4,893 & 24,319 & 21,970 & 180 & 273 & 284 & 8,438 & $4,700,400$ \\
\hline 2012 & 1,638 & 3,478 & 24,673 & 20,810 & 202 & 409 & 632 & -- & $4,381,960$ \\
\hline 2013 & 1,622 & 2,155 & 24,883 & 17,347 & 28 & 209 & 289 & 6,916 & $3,942,600$ \\
\hline 2014 & 1,219 & 677 & 25,479 & 15,250 & 19 & 197 & 69 & 6,003 & $3,610,740$ \\
\hline 2015 & 1,014 & 711 & 26,493 & 15,961 & 21 & 36 & 71 & 6,074 & $3,740,720$ \\
\hline 2016 & 1,164 & 893 & 21,303 & 9,887 & 21 & 31 & 37 & 5,656 & $2,552,120$ \\
\hline 2017 & 1,713 & 3,453 & 22,175 & 12,074 & 44 & 85 & 695 & 6,259 & $2,957,620$ \\
\hline
\end{tabular}

Information provided by Alaska Department of Natural Resources and U.S. Bureau of Land Management. The figures in this table will change as data are reviewed and updated.

after 2010, State claim and prospecting site totals are not directly comparable to previous years. After 2016, new State prospecting sites and total prospecting sites are not directly comparable to previous years.

Claim totals comprise Mining Claims (including "River Bottom Navigable" subtype) and Leasehold Locations whose claimants filed an Annual Affidavit of Labor, and claims initiated on State-selected land. There were 61 active 40-acre claims and 202 active 160-acre claims on Stateselected land in 2017, as compared with 127 active 40-acre claims and 43 active 160-acre claims on State-selected land in 2016.

bIncludes claim fractions varying from 1 to 39 acres.

- - = Not reported 


\section{Ambler Mining District}

There were several new developments related to the Ambler Mining District in 2017. The Alaska Industrial Development and Export Authority (AIDEA) completed its application for permits related to the construction and operation of an approximately 211-mile-long, all-season industrial road into the district in 2016. In February 2017, the U.S. Bureau of Land Management (BLM) published a Notice of Intent initiating the permitting process under the National Environmental Policy Act for the preparation of an Environmental Impact Statement (EIS) for the proposed road project. This initiates the public scoping process, which continued through the end of 2017. The BLM stated they will complete the final EIS by December 30, 2019.

In April 2017, Trilogy Metals Inc. signed an agreement with South32 Limited, an Australian company, granting South32 the option to form a 50/50 joint venture pursuing Trilogy's Upper Kobuk Mineral Projects. The projects include the Arctic and Bornite deposits, the exploration and option-to-lease agreement with NANA Regional Corporation, Inc., and the remainder of Trilogy's State mining claims along the 62-mile-long volcanogenic massive sulfide belt in the Ambler Mining District.

South32 Limited's initial \$10 million investment was spent on exploration at Trilogy Metals Inc.'s Bornite carbonate-hosted copper-replacement deposit in the southern Brooks Range (photo 5). To date, the company has defined an indicated and inferred resource of more than 200 million tons averaging 1.58 percent copper for greater than 6.3 billion pounds of copper (appendix D).

\section{Bornite}

The 2017 Bornite exploration program included drilling nine diamond drill holes totaling 27,680 feet, a detailed ground gravity survey, and soil sampling using a deep-penetrating geochemical method. The drill program tested the overall extent of the mineralizing system, with large step-outs targeting high-grade copper mineralization north and east of previously identified resources. The initial three drill holes (10,115 feet) yielded thick and continuous intervals of copper mineralization and represent up to 1,000 -foot offsets from holes completed in 2013. Highlights include: DDH RC17-234 intersected three intervals totaling 275 feet averaging 1.10 percent copper; DDH RC17-235W intersected two intervals totaling 108 feet averaging 0.90 percent copper; and DDH RC17-236 intersected two intervals totaling 382 feet averaging 1.06 percent copper. The first round of drilling demonstrated the mineralizing system still persists down-dip. Results from four further drill holes, totaling 14,176 feet and representing 1,000- to 1,300-foot offsets from the first three holes, continued to show significant intervals of high-grade copper. Highlights include: DDH RC17-237 intersected two intervals totaling 100 feet averaging 0.73 percent copper; DDH RC17-238 intersected four intervals totaling 106 feet averaging 1.03 percent copper; DDH RC17-239 intersected three intervals totaling 166 feet averaging 1.36 percent copper; and DDH RC17-240 intersected one interval totaling 82.3 feet averaging 0.96 percent copper. Due to inclement weather, diamond drill holes RC17241 and RC17-242 were stopped before reaching target depth and were cemented in preparation for re-entry during the 2018 drill program.

Trilogy and South32 doubled the size of the Bornite footprint, which now measures 5,000 by 8,000 feet, and the grade-times-thickness map suggests newly recognized, northeast- and northwest-oriented controls on higher-grade mineralization. Study of voluminous three-dimensional structural data collected over the summer drill program will focus on defining preferred mineralized corridors as defined by vein and breccia orientations to develop a sense of ore and grade controls. Additionally, cobalt occurs as carrollite and cobaltiferous pyrite. Electron microprobe and metallurgical studies will be conducted to determine if cobalt can be concentrated into a saleable product. Bornite, chalcocite, and chalcopyrite at Bornite 


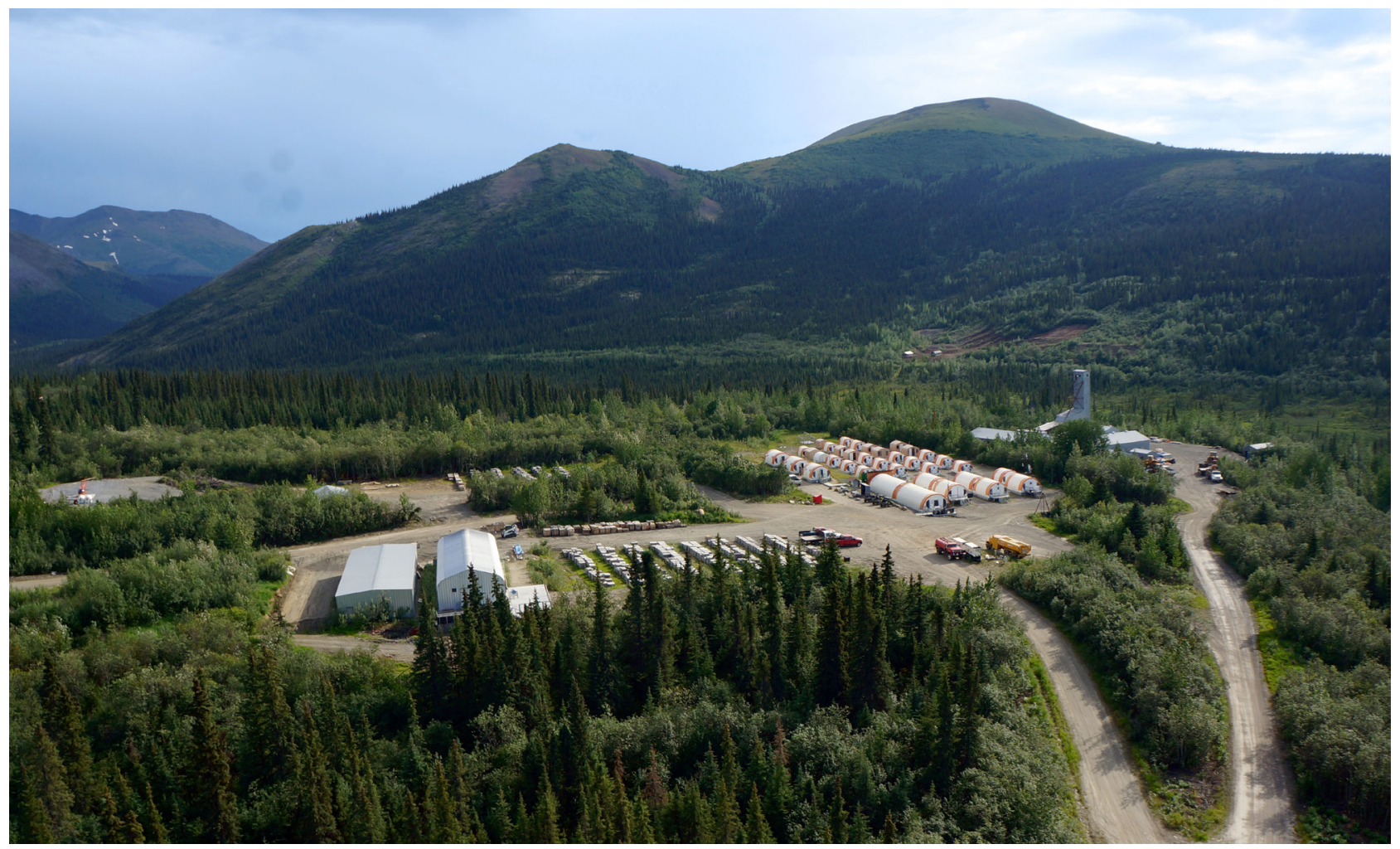

Photo 5. Through a 50/50 joint venture between Trilogy Metals Inc. and South32 Limited, South32 funded a \$10 million drill program targeting the northeast-dipping continuation of the high-grade-copper South Reef and New Reef zones at Bornite. Photo courtesy of Erin Workman, Trilogy Metals Inc.

form a high-quality copper concentrate with no recognized deleterious materials.

Trilogy's gravity survey was collected on a 330-foot grid spacing, including 845 gravity stations over an area of approximately 2.2 by 1.2 miles. Three-dimensional-constrained, inversion gravity modeling of the data suggests Bornite's mineral system is increasing in depth towards the north and northeast and suggests the system is still open. DDH RC17-239 was a gravity-model-derived drill target east of Trilogy's main 2017 target area.

In December 2017, South32 Limited committed to funding a $\$ 10$ million budget and exploration program for the Bornite project in 2018.

\section{Arctic}

Trilogy Metals Inc. announced a \$5.1 million budget for their Arctic volcanogenic massive sulfide project in the southern Brooks Range in March 2017. Work primarily will support creating a prefeasibility study (PFS), which will incorporate all information collected over the past two years of infill drilling and related prior studies, as well as 2017's studies to determine the placement of all site facilities and on-going environmental data collection. In April 2017, Trilogy completed a metallurgical test program using sample material collected in 2016. Compared to a 2012 study, copper recoveries improved from 87 to 92 percent, zinc recoveries improved from 87 to 88 percent, the copper concentrate's average grade remains at 29 percent, and the zinc concentrates average grade improved from 56 to 60 percent. Additionally, in-pit geotechnical and hydrology studies were completed to a PFS level.

In April 2017, Trilogy announced a mineral-resource update for Arctic. At a base-case 0.5 percent copper-equivalent cut-off grade, the Arctic deposit is estimated to contain in-pit indicated resources of 39.7 million tons at 3.07 percent copper, 4.23 percent zinc, 0.73 percent lead, 0.018 
ounce of gold per ton, and 1.39 ounces of silver per ton for 2.4 billion pounds of contained copper and 3.4 billion pounds of contained zinc. Inferred resources include 3.9 million tons at 1.71 percent copper, 2.72 percent zinc, 0.60 percent lead, 0.011 ounce of gold per ton, and 28.7 ounces of silver per ton for 131 million pounds of contained copper and 210 million pounds of contained zinc (appendix D). Mineral resource estimates are made from a three-dimensional block model with a nominal block size of 33 by 33 by 16 feet and utilize data derived from 152 drill holes in the vicinity of the Arctic deposit. In June 2017, Trilogy hired contractors to prepare their Arctic PFS technical report, and in November 2017, Trilogy filed an updated NI 43-101 report for Arctic.

Trilogy Metals Inc.'s 2017 Arctic field program included 2,576.1 feet of diamond drilling in five, PQ-diameter holes to collect two tons of representative mill-feed ore material to conduct bulk ore-sorting studies. An additional 898 feet of sonic drilling was completed to collect geotechnical, hydrological, geothermal (permafrost), and hydrogeological information for planning the tailings-management facilities and waste-rock dump for the project in support of the upcoming PFS. Trilogy also continued baseline environmental data collection and continues to advance Arctic's acid-base-accounting static and kinetic test work.

\section{WESTERN REGION}

\section{Graphite Creek}

Graphite One Resources' Graphite Creek deposit, the United States' largest large-flake graphite deposit, is located on the Seward Peninsula 34 miles north of Nome. Graphite Creek is an advanced-exploration-stage project progressing towards the evaluation phase. The Graphite Creek deposit has an indicated resource of 11.38 million tons of graphite grading 7.2 percent carbon as graphite $(\mathrm{Cg})$ for contained graphite of 1.64 billion pounds, and an inferred resource of 78.53 million tons grading 7.0 percent $\mathrm{Cg}$ for contained graphite of 10.95 billion pounds (appendix D).
Indicated and inferred resource estimates are calculated based on a six percent cut-off grade and 48 drill holes totaling 24,600 feet. The deposit remains open along strike as well as down dip, and airborne resistivity data suggest additional potential for resources is present on the broader Graphite Creek property.

Following a comprehensive product-development program in 2016, in February 2017 Graphite One released their inaugural preliminary economic assessment (PEA) for development of a graphite manufacturing project for Graphite Creek; it was amended in June 2017. In the PEA, the project is initially conceived as a vertically integrated manufacturer of high-grade coated spherical graphite (CSG), with mining and processing facilities near Nome, Alaska, and advanced material processing taking place at a dedicated graphite product manufacturing facility; possibly in Washington state. Annual production of CSG and other graphite specialty materials is projected at 61,000 tons when full production is reached in year six. A minimum of 40 years of indicated and inferred resources grading seven percent $\mathrm{Cg}$ have been identified to sustain full-scale operations. Approximately 1,122,000 tons of graphite-bearing material are projected to be mined per year, with extraction and recovery of 66,000 tons per year of concentrate grading 95 percent $\mathrm{Cg}$. The concentrate would then be transported overland to the port of Nome and shipped by barge to a product-manufacturing plant, where it would undergo thermal purification, mechanical-chemical processing (spheronization), classification, coating of spherical graphite, and heat treatment. The envisioned manufacturing plant would deliver 46,132 tons of high-grade coated spherical graphite per year for lithium-ion battery applications along with 14,881 tons of refined, sub-20-micron graphite powder per year for various end-uses.

Graphite One entered into a memorandum of understanding with the Alaska Industrial Development and Export Authority (AIDEA) to explore opportunities to collaborate on the development of Graphite One's proposed project. 
In May 2017, Graphite One received a site-assessment report prepared by AIDEA. AIDEA and Graphite One are currently reviewing strategies to maximize local economic benefits and job opportunities, potential opportunities to locate the manufacturing plant in Alaska, define venues for stakeholder input, identify activities requiring permitting, and examine AIEDA-infrastructure funding possibilities.

\section{Round Top}

Western Alaska Copper \& Gold conducted exploration drilling at their Round Top property in western Alaska in July. Round Top, 55 miles south of Galena, includes porphyry coppermolybdenum, skarn, and lead-zinc-silver carbonate-replacement type mineralization (photo 6). Western Alaska drilled nine holes for a total of 7,120 feet. Drilling encountered a well-preserved lithocap characterized by extensive quartz-sericite-pyrite alteration, as well as temporally late, intermediate-argillic and possibly advance-argillic alteration overprinting a complex porphyry intrusive suite, including a diatreme-like fragmental unit. The high-level alteration zone contains widespread pyrite-chalcopyrite-chalcocite-covellite mineralization extending to at least 1,150 feet depth. A 150- to 500-foot-thick leached cap overlies the mineralization, including supergene-enriched chalcocite.

Western Alaska’s 2017 drilling bracketed the Round Top East Lobe porphyry, extended the dimension of the supergene chalcocite blanket encountered in 2016, and discovered new copper sulfide mineralization in drill holes RT17-18 and RT17-19. Within the fragmental unit, DDH RT17-19 intercepted both secondary copper enrichment in upper portions of the hole and multiple intercepts of primary copper sulfide mineralization that extended to the bottom of the hole at 1,176.9 feet; thin zones of biotite-magnetite-chalcopyrite mineralization were encountered below 1,000 feet depth. The overall weighted average of seven intervals, using a cut-off grade of 0.25 percent copper, is 544.5 feet of 0.43 percent copper, 0.13 ounce of silver per

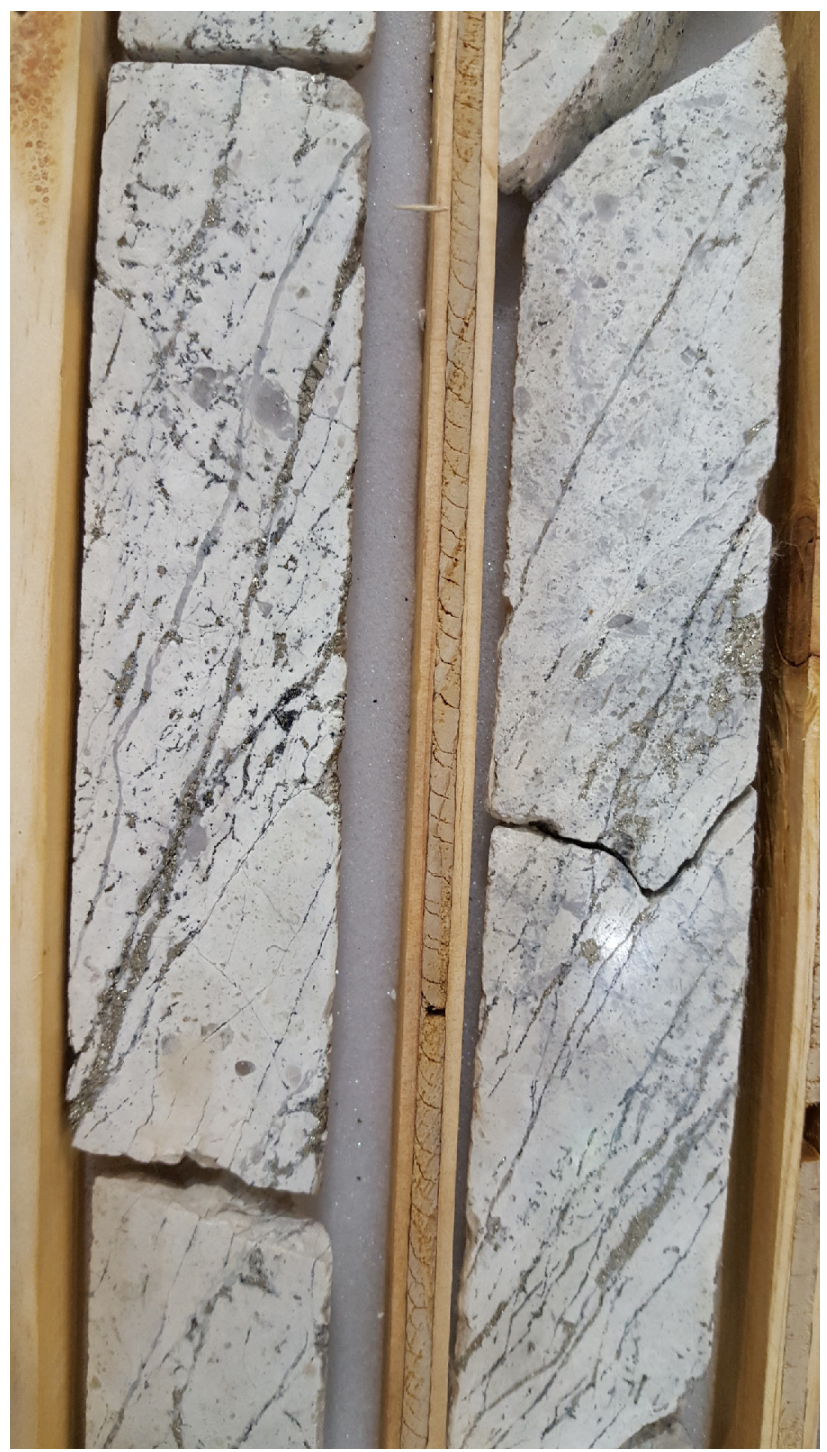

Photo 6. 2017 drilling encountered quartz-sericitepyrite and argillic alteration in the Round Top coppermolybdenum porphyry system in western Alaska being explored by Western Alaska Copper \& Gold. Photo courtesy of Melanie Werdon, DGGS.

ton, and 0.014 percent molybdenum. A 94.2-foot interval between 482.6 feet and 576.8 feet averaged 0.92 percent copper. DDH RT17-018 cut 212 feet of 0.49 percent copper and 0.519 ounce of silver per ton in three intervals within a temporally early quartz monzonite porphyry.

To date, limited drilling suggests a potential copper-resource area of roughly 4,000 feet by 3,000 feet that is open to expansion, with a core of higher grade copper about 1,600 feet by 1,600 feet in dimension. The core area, in addition to 
the enriched chalcocite blanket, contains chalcopyrite, covellite, lesser bornite, and significant silver values. The Round Top mineral system is cored by a 6,500 foot by 6,500 foot copper-insoils anomaly coincident with a 100-nanotesla magnetic anomaly, the eastern lobe of which was the target of 2017 drilling. Three-dimensional magnetic susceptibility modeling of airborne magnetic data shows a pipe-like apophysis immediately below the high-level argillic cap, which is coincident with the best drilling results to date.

\section{EASTERN INTERIOR}

\section{Peak}

Peak Gold, LLC is a joint venture between Contango ORE Inc. and Royal Alaska, LLC, a wholly owned subsidiary of Royal Gold Inc., formed to explore the Peak (formerly Tetlin) project area near Tok. The project contains the Main Peak and North Peak polymetallic goldsilver-copper skarn deposits and numerous other prospects and prospective targets. In June 2017, Peak Gold, LLC announced an updated openpit resource estimate for the Main and North Peak areas, which was calculated at a gold price of $\$ 1,200$ per ounce and a cut-off grade of 0.015 ounce of gold-equivalent per ton (gold plus 0.0122 times silver). Measured and indicated resources include 11,685,000 tons at a grade of 0.106 ounce of gold per ton, 0.414 ounce of silver per ton, and 0.16 percent copper, for contained metal of 1,239,900 ounces of gold, 4,833,700 ounces of silver, and 37.3 million pounds of copper. The total measured, indicated, and inferred resource is 17,251,000 tons at a grade of 0.0869 ounce of gold per ton, 0.428 ounce of silver per ton, and 0.16 percent copper, for contained metal of 1,502,000 ounces of gold, $7,387,000$ ounces of silver, and 55 million pounds of copper (appendix D).

Contango ORE collected 79 rock samples, 1,172 soil samples, and 357 pan concentrate samples, drilled 49,218 feet of diamond drill core in a three-phase drilling program, and conducted 30-line miles of ground-based geophysical surveys as part of their approximately $\$ 11.9$ million exploration program in 2017 (photo 7). In addition to work in their Peak project area, Peak Gold, LLC conducted systematic stream-sediment sampling in their Noah claim block and identified multiple gold-bearing samples in streams draining the intrusion-related Hona prospect. Visible gold was reported in pan concentrate samples from elsewhere on the Noah block. An additional surface-reconnaissance program was carried out in the Tetlin Hills.

In early April 2017, Peak Gold, LLC completed Phase I drilling, consisting primarily of holes around the edges of the North Peak deposit area to better define the resource. Six initial holes were drilled in the True Blue Moon target area, a new prospect generated from airborne magnetic and resistivity surveys and surface reconnaissance data. Drilling highlights (using a 0.015 ounce of gold per ton lower cut off with no internal waste intervals greater than 10 feet) include: DDH TET17353 intersected 5.77 feet grading 0.267 ounce of gold per ton, and DDH TET17357 intersected 17.5 feet grading 0.025 ounce of gold per ton.

In July 2017, Peak Gold, LLC completed its Phase II drilling program, primarily testing targets within 1 mile of known mineralization in the Main Peak and North Peak zones. These exploration efforts resulted in the discovery of West Peak Extension just northwest of the Main Peak deposit. Highlights include: DDH TET17379 intersected one interval with 26.8 feet grading 0.152 ounce of gold per ton, and another interval with 95.5 feet grading 0.0738 ounce of gold per ton; DDH TET17368 intersected four gold-bearing intervals, with one 2.8 -foot interval grading 0.0788 ounce of gold per ton; DDH TET17369 intersected 46.2 feet grading 0.0802 ounce of gold per ton; DDH TET17381 intersected 4.4 feet grading 0.0370 ounce of gold per ton; DDH TET17386 intersected 17.1 feet grading 0.0236 ounce of gold per ton; DDH TET17388 had four intersections with one 49.4-foot interval grading 0.0484 ounce of gold per ton; DDH TET17390 had three 


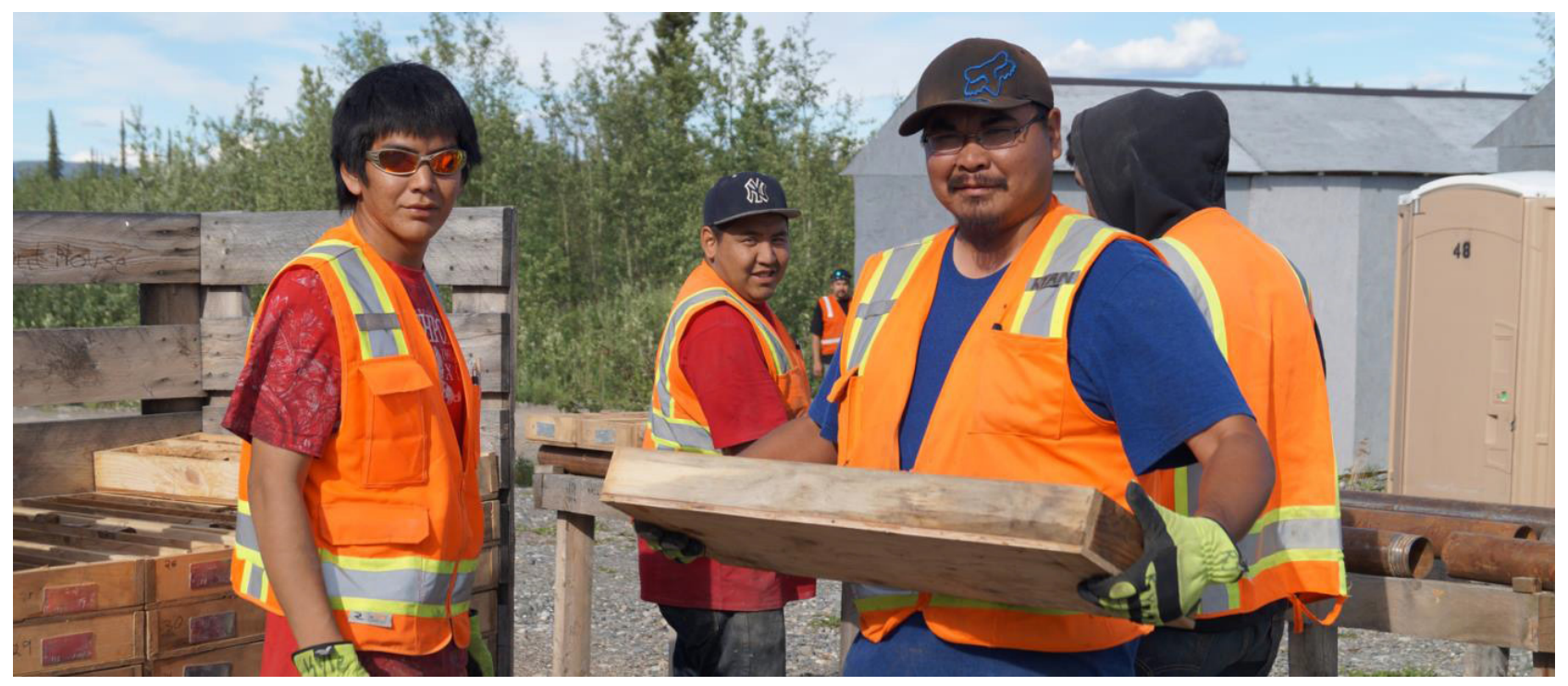

Photo 7. Handlers move core at the Peak project in eastern interior Alaska. Peak Gold, LLC drilled a total of 49,218 feet in 2017, testing the Main Peak, North Peak, and West Peak Extension areas. Photo from: Contango ORE, Inc., September 20, 2017, Peak Gold joint venture project (presentation); last accessed September 28, 2018; http://www.contangoore.com/presentations/CTGO-Presentation-September2017.pdf.

intercepts, one with 5 feet grading 0.184 ounce of gold per ton. The new West Peak Extension mineralization is open up-dip to the southwest, as well as along strike and down-dip to the southeast along the undrilled north side of the Main Peak deposit.

In October 2017, Peak Gold, LLC completed their eight-hole, Phase III drilling program offsetting the West Peak Extension area. Five of these holes intersected gold-bearing intervals, but the thickness was not comparable to the Phase II program hole (DDH TET17379) that originally generated the interest in the zone; future drilling in this immediate area will depend upon final interpretation of the data. Two holes were also drilled near the North Peak area.

Peak Gold, LLC also conducted a 48-hour, cyanide-leach, bottle-roll metallurgical test at North Peak zone; gold recoveries from 19 composite samples ranged from 90.4 to 99.6 percent, and averaged 97.5 percent. The majority of the composites (15 of 19) demonstrated gold leaching was primarily completed within 24 hours. Average silver extraction was 65 percent (low of 26 percent, high of 92 percent) with grades ranging from 0.002 to 0.125 ounce of silver per ton.
During Phase II drilling, Peak Gold also drilled three holes in Main Peak Zone for metallurgical testing and to prove the zone's deposit geometry; drilling returned outstanding grades, as these holes were designed to follow known mineralization. Composite samples from the Main Peak metallurgical holes will be submitted for 48-hour cyanide leach bottle roll testing similar to the North Peak composites.

\section{Pogo Area}

To ensure continued mining into the future, Sumitomo Metal Mining Pogo LLC invested approximately $\$ 10$ million in exploration near Pogo mine in 2017. At least five high-grade gold zones (Liese, East Deep, North, Fun, and South Pogo) have been discovered within 1 mile of the mill; these zones are currently contributing ore to the mill, or are expected to in the near future. Pogo is permitted to operate through 2019, but extensive exploration efforts are underway to identify additional ore resources and reserves.

Sumitomo Metal Mining conducted a controlled-source audio magnetotelluric (CSAMT) survey over their entire Pogo-area property in 2017. They identified low-resistivity anomalies 
in the near-mine Fun Zone and in the Goodpaster area about 2 miles west of the mine. Fun Zone granitic gneiss hosts gold mineralization in sheeted quartz veins, quartz-sulfide stockworks, and sulfide replacements. Sampling identified intervals with multi-ounce gold grades, and the potential for a lower-grade alteration halo. As of 2017, the Fun Zone's continuity and geometry haven't been clearly defined yet.

West of Pogo mine, across the Goodpaster River, drilling was targeted on a greater than 5,000-foot-long CSAMT low-resistivity anomaly; drilling intersected the Goodpaster vein-breccia system, which has an estimated strike of 241 degrees azimuth and a 35-degree dip. Exploration drill holes DDH 17-040 and DDH 17-041 intersected intervals of 17.5 feet of 1.739 ounces of gold per ton; 39.1 feet of 0.004 ounce of gold per ton; 17.0 feet of 0.001 ounce of gold per ton; and 22.8 feet of 0.103 ounce of gold per ton. The Goodpaster vein is hosted primarily by paragneiss.

\section{Fort Knox}

Kinross Gold Corporation prioritized 2017 exploration drilling towards increasing mineral resources at its Fort Knox mine near Fairbanks. Positive intercepts were encountered during 2016 drilling of the east and south wall of the existing pit, and additions to the site's reserves before depletion were 254,000 ounces of gold. In 2017, 8,914 feet were drilled in the east wall of the pit.

On December 12, 2017, Kinross gained mineral rights to the Gilmore land immediately west of the Fort Knox pit. As a result, Kinross added 2.1 million ounces of gold in estimated measured and indicated resources and 300,000 ounces in estimated inferred resources. Kinross reported results for nine reverse-circulation holes. A total of 13 holes were drilled from the Fort Knox open pit, and 22 were located west of the mine on the Gilmore property. Kinross's Gilmore exploration drilling cut many intervals meeting or exceeding current mine cut-off grades, and a few holes encountered much higher grades, including: FFC17-1690 intersected 35.1 feet grading 0.153 ounce of gold per ton; FFR16-1585 intersected
35.1 feet grading 0.120 ounce of gold per ton, and another intersection of 40.0 feet grading 0.100 ounce of gold per ton; and FFC17-1595 intersected 65.0 feet grading 0.0373 ounce of gold per ton. In 2018 Kinross expects to complete a feasibility study for the Gilmore property.

\section{Circle-Coffee Dome-Ryan Lode}

Kinross Gold U.S.A., Inc. also collected and geochemically analyzed soil samples on their Ryan Lode and Coffee Dome properties, and they conducted exploration on their Circle-area claims in 2017.

\section{Golden Summit}

Additionally, Freegold Ventures Limited commenced drilling in May at their intrusion-related Golden Summit property north of Fairbanks. The property hosts an indicated resource of 67.8 million tons at 0.020 ounce of gold per ton hosted within the Dolphin intrusion $(1,363,000$ contained ounces of gold) and an inferred resource of 78.8 million tons at 0.020 ounce of gold per ton (1,584,000 contained ounces of gold) (appendix D). In 2017 Freegold drilled a total of 27 holes in an area north of the current resource area, where previously completed rotary air-blast drilling identified the potential for higher-grade material. Vertical holes averaging 230 feet deep on a roughly 160 foot grid tested the northern boundary of the current oxide resource. The majority of the holes returned average grades above the internal cut-off used in Freegold's 2016 preliminary economic assessment, demonstrating the potential for expansion of the current oxide resource at Golden Summit. Highlights of 2017 drilling include DDH GSDL 17-16, which intersected one of the highgrade, east-west-trending veins that are documented in the Dolphin-Cleary area and visible gold was noted. DDH GSDL 17-17 and 17-18 intersected intrusion-hosted mineralization in an area where intrusive rock had not previously been encountered; the holes intersected 226.4 feet of 0.012 ounce of gold per ton and 211.6 feet of 0.015 ounce of gold per ton, respectively. DDH GSDL 17-26 intersected 231.3 feet grading 0.024 ounce of gold per ton, and DDH GS 17-13 intersected 
172.2 feet of oxide material grading 0.016 ounce of gold per ton. Both the resource-expansion drilling and the metallurgical program underway are aimed at improving the overall project economics. Metallurgical test work includes further oxidation treatment on all identifiable sulfide materials, as well as ultra-fine-grind testing undertaken to explore grind size versus recovery relationships.

Freegold also conducted a ground-based induced polarization survey west of the Dolphin resource in 2017. Combined with soil geochemistry of anomalous gold, bismuth, and tungsten, the geophysical survey outlined an additional 5,000foot by 1,000-foot expansion target west of the previously identified expansion area. The Dolphin resource area remains open to the west and southwest. Another area that may have the potential to enhance the overall grade of the resource is the extension of the original high-grade Cleary Hill vein system.

\section{Shorty Creek}

Freegold Ventures Limited commenced drilling in July at its copper-molybdenum intrusion-related Shorty Creek project approximately 78 miles northwest of Fairbanks (photo 8). The 9,062-foot drill program focused on expanding known mineralization at Hill 1835, as well as initial drill testing the Steel Creek target, a strong magnetic high similar to Hill 1835 immediately to the southwest.

Freegold's Hill 1835 drilling program intercepted significant widths of copper, gold, silver, cobalt, and tungsten (expressed as tungsten

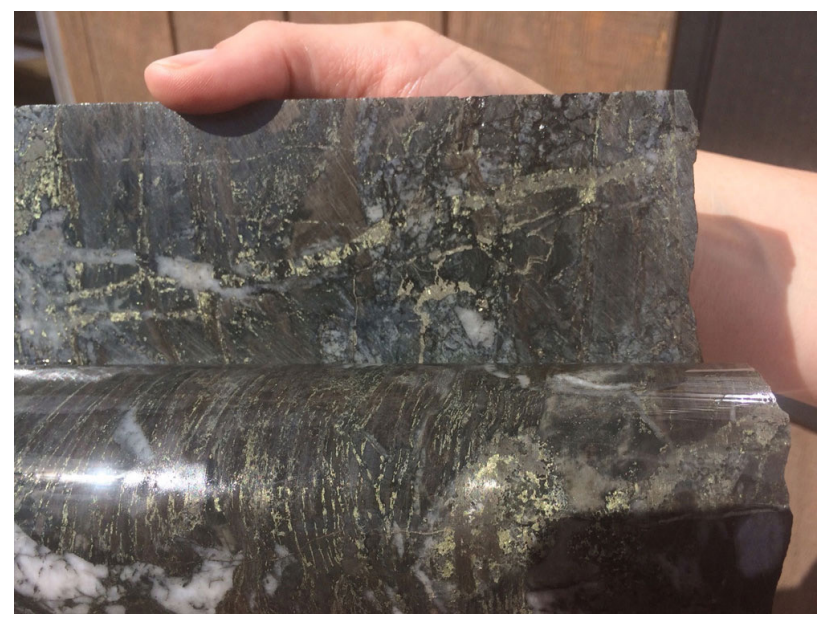

trioxide and abbreviated WO3). Vertical step-out holes SC 17-01 and SC 17-02 were drilled 330 feet and 650 feet southwest of 2016 drilling, respectively. Hole SC17-01 intersected 1,181.1 feet of 0.24 percent copper, 0.118 ounce of silver per ton, 0.01 percent cobalt, and 0.03 percent WO3. Hole SC 17-02 intersected 1,338.6 feet of 0.27 percent copper, 0.145 ounce of silver per ton, 0.0085 percent cobalt, and 0.05 percent WO3, including 1,112.2 feet of 0.30 percent copper and 0.167 ounce of silver per ton. Angle holes SC 17-03 and SC17-04 were drilled on the eastern edge of Hill 1835's magnetic high. SC 17-03, lost at 1,188.3 feet in strong copper mineralization, intersected 344.5 feet of 0.27 percent copper, 0.197 ounce of silver per ton, 0.0114 percent cobalt, and 0.02 percent WO3. Hole SC 17-04 encountered significant fault material and intersected 246.1 feet of 0.15 percent copper, 0.0770 ounce of silver per ton, and 0.0079 percent cobalt.

An initial exploratory hole at Steel Creek, located 1.5 miles northeast of Hill 1835, was drilled to a depth of $1,425.5$ feet near the center of an 8,200-foot by 6,500-foot magnetic anomaly. DDH17-06 returned anomalous copper, gold, silver, cobalt, and tungsten, consistent with the metal suite seen at Hill 1835. Additional drilling will be necessary to further test this target area.

\section{Livengood}

In February 2017, International Tower Hill Mines Ltd. (ITH) made the final $\$ 14.7$ million payment due for the acquisition of certain mining claims and related rights in the vicinity of its advanced-exploration-stage, intrusion-related, Livengood gold project 70 miles northwest of Fairbanks. The Livengood gold project has total estimated mineral resources, including inferred

Photo 8. Drilling at the copper-molybdenum intrusion-related Shorty Creek project northwest of Fairbanks encountered porphyry-style chalcopyrite and bornite mineralization in potassically and sericitically altered, hornfelsed sedimentary rocks cut by porphyritic dikes and sills. Photo from: Freegold Ventures Limited, November 16, 2017 news release; last accessed September 28, 2018; https://www.freegoldventures. com/news/2017/freegold-intersects-339-metres-grading0.45-cu-equivalent-at-shorty-creek/. 
resources, of 637 million tons averaging 0.020 ounce of gold per ton, for 12.6 million ounces of contained gold. The resource is based on 783 drill holes totaling 717,435 feet and a gold price of $\$ 1,230$ per ounce (appendix D).

ITH's \$6.3 million 2017 work program implemented specific recommendations from their 2016 prefeasibility study (PFS). Work focused on improving mineralization and alteration models used to support the resource block model, evaluating alternative block models for production schedule opportunities, and completing several phases of metallurgical work to better define and optimize the flow-sheet and recovery parameters; this work targeted aspects that could deliver the highest net-present-value increase for the least engineering expenditure at the Livengood project (photo 9).

Specifically, metallurgical test work indicated gold recovery is locally negatively impacted by antimony in the form of stibnite and jamesonite. Only 50 percent of prior drill intercepts were assayed for antimony, hence, approximately 20,000 stored pulps of all drill intercepts in the 2016 PFS-modeled pit were re-assayed for multiple elements to allow modeling and variance analysis to be completed, which could potentially improve the geologic model used to support the block model, and thereby potentially improve overall gold recovery by the isolation of zones in the model with lower recoveries. Consultants are progressing on alternative block models and refinement of the multiple-indicator-kriging resource model. Geostatistical analysis to potentially cap grades and quantitatively evaluate the model projections against the drill intercepts will enable reliance on the grade-shell model for updating the 2016 PFS. Work in connection with the 2016 PFS indicated project economics are sensitive to recovery, grind size, reagent consumption and test conditions (oxygen, $\mathrm{pH}$, lead nitrate). Additional metallurgical test work is being conducted to allow better optimization of these critical variables.

ITH issued an updated NI 43-101 technical report for the Livengood project in April 2017. Updated all-in sustaining costs are now projected to be $\$ 976$ per ounce of gold and all-in costs are $\$ 1,247$ per ounce of gold including capital. The updated report determined a right-sized project configuration $(52,600$ tons per day), which showed reduced capital costs and improved operating costs; it also reports improved mineralization and alteration models for the Livengood gold deposit as well as the results of metallurgical studies to better define and refine the project flowsheet. ITH engaged BBA Inc. to provide technical guidance regarding modeling and metallurgy. ITH also maintained environmental baseline studies for future permitting, which have been on-going since 2008 .

\section{Alaska Range Project}

In July 2017, Coventry Resources Limited, owner of the Caribou Dome deposit and Senator prospect in the southern Alaska Range, completed its acquisition of Vista Minerals Pty Ltd.; the companies merged to form PolarX Ltd. Vista was earning rights on Millrock Resources Inc.'s Stellar copper-gold project immediately northeast of Caribou Dome, hence, in addition to Coventry and Vista, the property merger also involved Millrock. PolarX's newly consolidated properties, termed the Alaska Range Project, include the sediment-hosted-copper Caribou Dome deposit and Senator prospect; the Zackly copper-gold skarn deposit; the Jupiter, Mars, and Gemini porphyry copper-gold-molybdenum targets; and the goldonly Moonwalk target (figure 7). These properties fall within a 22-mile-long, northeast-trending corridor of elevated copper \pm gold in soils.

Coventry announced an initial Australian Joint Ore Reserves Committee (JORC)-compliant mineral-resource estimate for their Caribou Dome deposit in April 2017. The new resource totals 3.1 million tons grading 3.1 percent copper (using 0.5 percent lower cut-off grade) for contained metal of approximately 190 million pounds of copper (appendix D). Approximately 60 percent of the mineral resource occurs within approximately 500 feet of surface, including about 1 million tons averaging 4.4 percent copper at a 2 percent copper cut-off grade. To begin high-level 


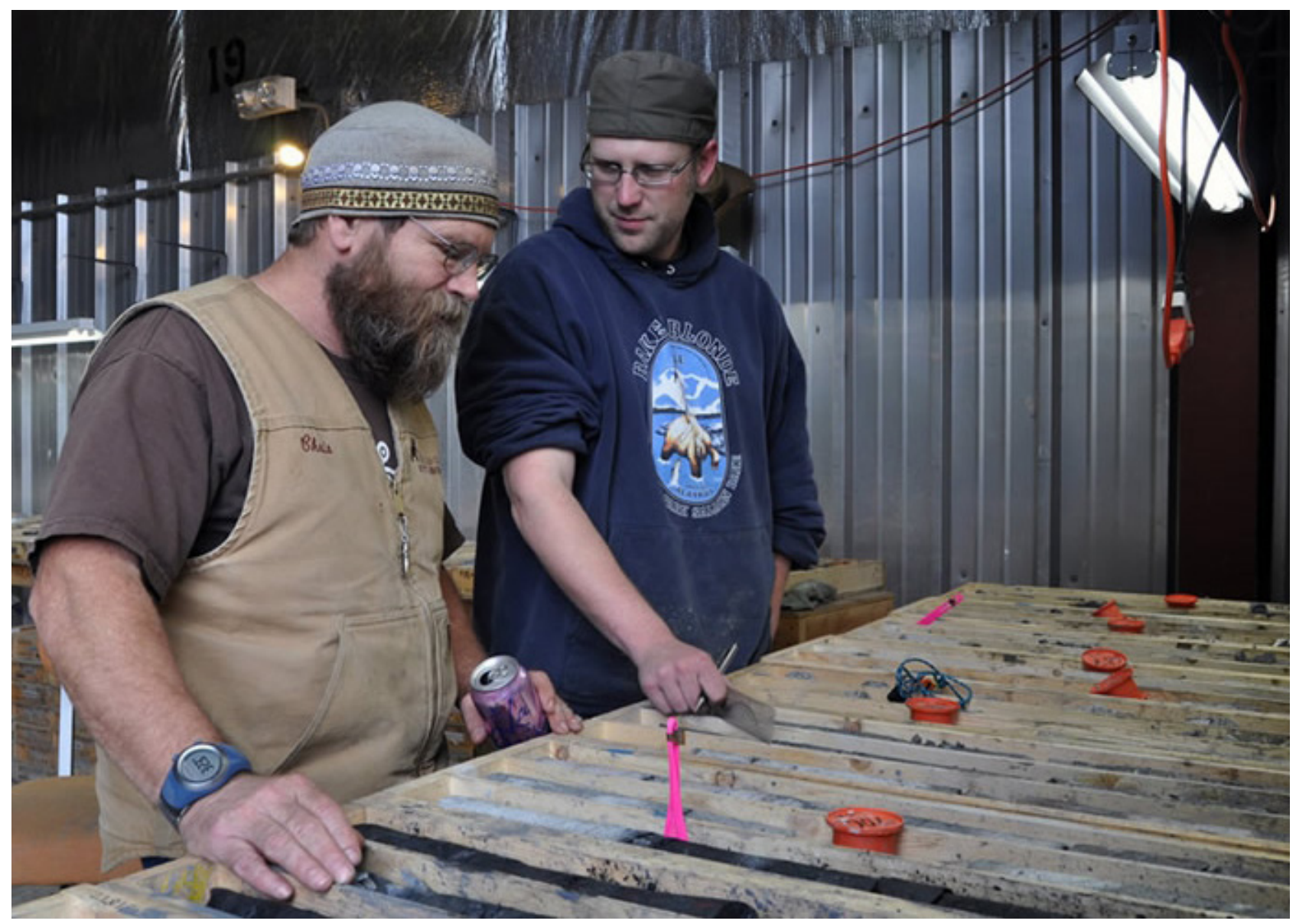

Photo 9. Chris Puchner, International Tower Hill's Livengood project Chief Geologist, looks over core. Evaluation of the property continues as metallurgical work is used to optimize production scenarios. Photo from: International Tower Hill; last accessed September 28, 2018; http://ithmines.com/livengood-gold-project/photogallery/\#\&gid=1\&pid=11.

evaluation of the technical and potential economic viability of an open pit, Coventry undertook a preliminary scoping study (PSS) based on using the highest-grade, near-surface material for a low capital expenditure open-pit starter operation. Deeper material below about 500 feet from surface contains approximately 40 percent of the total current resource estimate. The initial JORC-compliant resource for Caribou Dome does not yet fully capture the underground mining potential or potential along strike of the drilling to date. For the PSS, early stage metallurgy test work focused on conventional flotation recovery of copper in a concentrate form. A composite sample from ore lenses 4,5 , and 6 grading 5.03 percent copper yielded recoveries greater than 95 percent during rougher flotation tests and produced concentrates grading up to 24.5 percent copper. A sample from lenses 7 and 8 grading 7.4 percent copper yielded recoveries greater than 99 percent during all rougher flotation tests and produced concentrates grading up to 27.4 percent copper.

\section{PolarX funded geological and structural} mapping of outcrops and drill core in August to assist in future drill-site planning, as well as baseline environmental studies at Caribou Dome in preparation for moving their Alaska Range Project toward a planned prefeasibility study.

The Senator copper prospect was discovered in 2016 through a soil sampling program, which identified a 3 -mile by 1.5 -mile area with greater than 0.01 percent copper in soils, and locally intense iron alteration (jarosite and hematite) and 


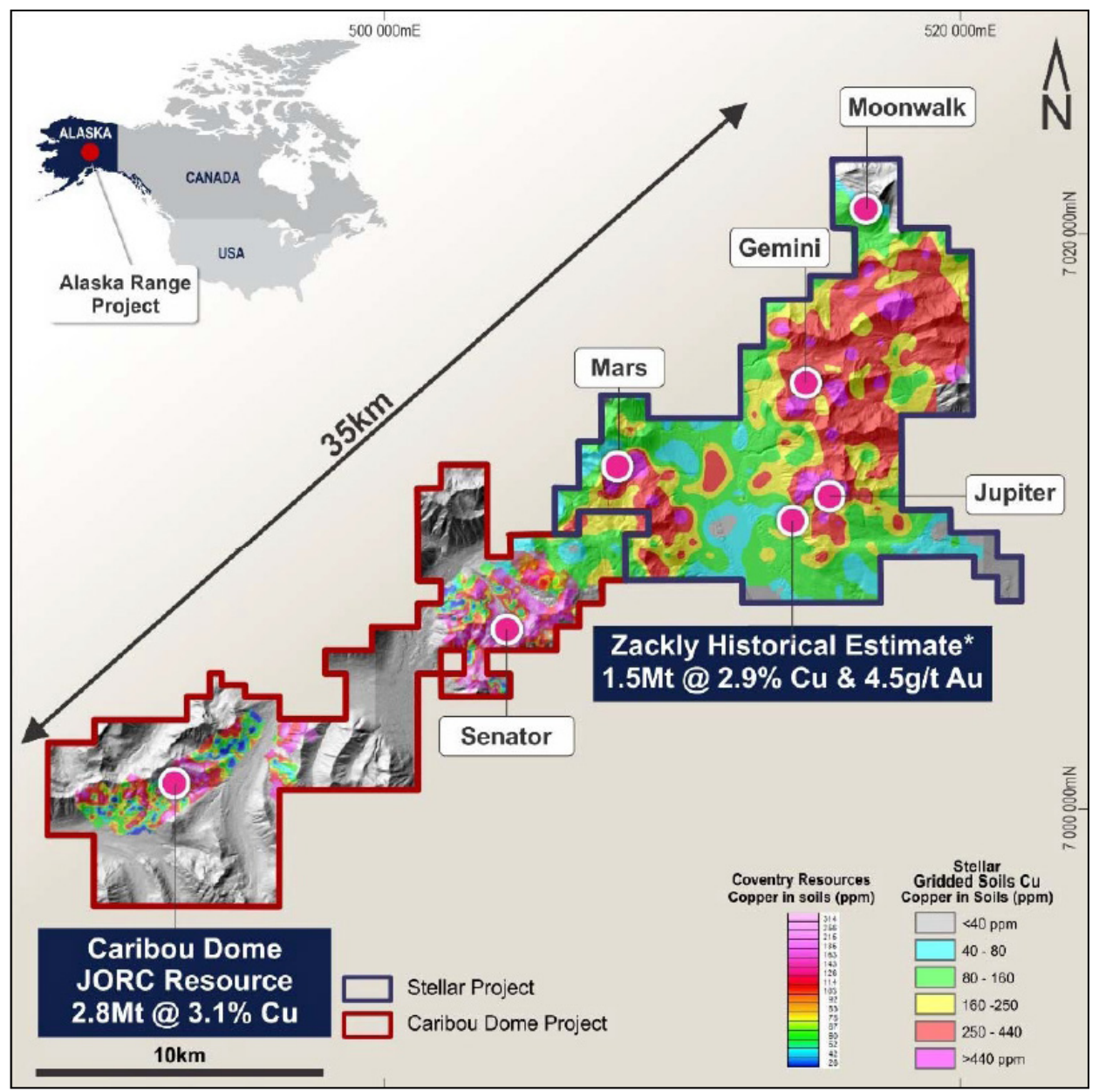

Figure 7. Map of PolarX's Alaska Range Project prospects and occurrences, showing copper-in-soils in parts per million. Figure source: PolarX Ltd.; last accessed October 22, 2018; https://www.polarx.com.au/announcements/.

copper oxides on fracture surfaces (photo 10). In August 2017, PolarX collected five lines of induced polarization (IP) data, totaling 4.0 linemiles, across the Senator copper-in-soils anomaly.

The Mars prospect is characterized by coincident copper, gold, molybdenum, and silver in broadly spaced soil samples over approximately 6,500 feet by 5,000 feet. Up to 7.4 percent copper and 0.053 ounce of gold per ton is present in rock-chip samples. In August 2017, PolarX conducted an initial, 3-line, 1-tie-line IP survey over Mars. The IP results show a buried chargeability anomaly located 330 to 500 feet below the surface geochemical anomaly. The full extent of the chargeability anomaly is not yet known; the anomaly extends to the edge of the 2,600-foot-wide survey area which lies within the 6,500-foot-long soil anomaly.

PolarX's Zackly copper-gold skarn deposit in the south-central Alaska Range has a new JORC-compliant inferred resource of 3.75 million tons grading 0.058 ounce of gold per ton for 213,000 contained ounces of gold, 1.2 percent copper for 45.4 million pounds copper, and 0.408 ounce of silver per ton for 1.5 million ounces of silver (appendix D). In August 2017, PolarX commenced environmental baseline planning to monitor surface and ground water and a preliminary wetlands survey. Infill IP surveys, totaling 6.6 line-miles, were undertaken across the Main Skarn for orientation purposes, and along strike in both directions to assist targeting exploration drill holes. 
At the end of August 2017, Millrock Exploration Corp. initiated resource-delineation drilling at Zackly on behalf of PolarX, and by October 2017, completed the 6,739-foot program. One rig drilled two, NQ2-diameter core holes to evaluate potential eastern and western extensions of known mineralization, and the second rig drilled 11, HQ3-diameter core holes to twin/infill historically drilled holes in the Main Skarn deposit. This drilling allowed the calculation of a revised resource estimate to JORC standards (see above and in appendix D). The core was also used in preliminary metallurgical test work to identify processing options for copper and gold. Highlights of 2017 drilling include: 60.5 feet grading 1.3 percent copper and 0.035 ounce of gold per ton from 556.1 feet in DDH ZM-17010; 109.7 feet grading 1.2 percent copper and 0.038 ounce of gold per ton from 322.4 feet in DDH ZM-17002; and 67.0 feet grading 2.1 percent copper and 0.050 ounce of gold per ton from 95.0 feet in DDH ZM-17007.

Drilling at Zackly revealed thick zones of covellite and bornite, plus disseminations and stringers of native copper; occasional coarse gold was also observed. Multiple phases of copper mineralization and associated skarn alteration are present in most holes drilled to date. An initial mineralizing event likely occurred when the diorite intrusion formed weakly mineralized skarns in the adjacent silty limestones and volcanic rocks, introducing disseminated iron, copper, and molybdenum sulfides. A later and stronger overprinting mineralization event introduced widespread garnet-bearing skarns containing clots, veins, and disseminations of covellite, native copper and bornite, local secondary chalcocite, and zones of massive magnetite-bornite-chalcopyrite skarns up to approximately 10 feet thick. Geological evidence for a buried porphyry intrusion, observed in several holes, includes porphyry style veins, overprinting potassic alteration containing K-feldspar and secondary biotite, and sub-vertical hydrothermal breccias. The best mineralization in the skarn generally occurs in the stratigraphically upper part of the skarn body near the faulted contact with limestone.

\section{Elephant Mountain}

Elephant Mountain, an early stage exploration project operated by Endurance Gold Corporation, is centered on a Cretaceous, reduced intrusion-related gold system 76 miles northwest of Fairbanks. The Elephant Mountain project includes three properties: Elephant Mountain, Wolverine, and Trout (figure 8). The Elephant Mountain property contains, from southwest to northeast, the Pioneer, South Zone, Central Zone, North Zone, Pump Zone, and Elephant East targets. In April 2017, Endurance acquired an option to earn 100-percent ownership in the nearby Trout and Wolverine properties. The Wolverine property, located about 5 miles northeast of the Elephant Mountain property, contains the Wolverine target and a historically reported stibnite prospect. The Trout property, located about 6.84 miles east-northeast of the Elephant Mountain property, contains the Trout and South Fork targets.

In July 2017, Endurance reported results of an approximately 27-line-mile, time-domain pole-dipole induced polarization (IP) survey and a 24-line-mile ground-magnetic survey at their Elephant Mountain property. Resistivity data revealed a linear, east-west-trending low, which correlates with the primary fault cutting the Elephant Mountain intrusion. The IP survey defined a 4,000 foot by 2,000 foot chargeability anomaly at the North Zone and Pump Zone targets, confirmed a deeper-level chargeability anomaly at the Central Zone, and discovered a near-surface chargeability anomaly at the 2016 South Zone discovery. The magnetic survey confirmed low magnetic susceptibility is associated with intrusions and higher magnetic susceptibility is associated with hornfelsed sediments.

Endurance explored their Trout and Wolverine properties in July and August. Rock sampling at the South Fork target on the Trout property, within an east-west-striking structural zone at least 800 feet in length, returned multiple assays up to 0.302 ounce of gold per ton with anomalous lead, arsenic, bismuth, and silver. Oxidized sulfides were found with quartz veining, 


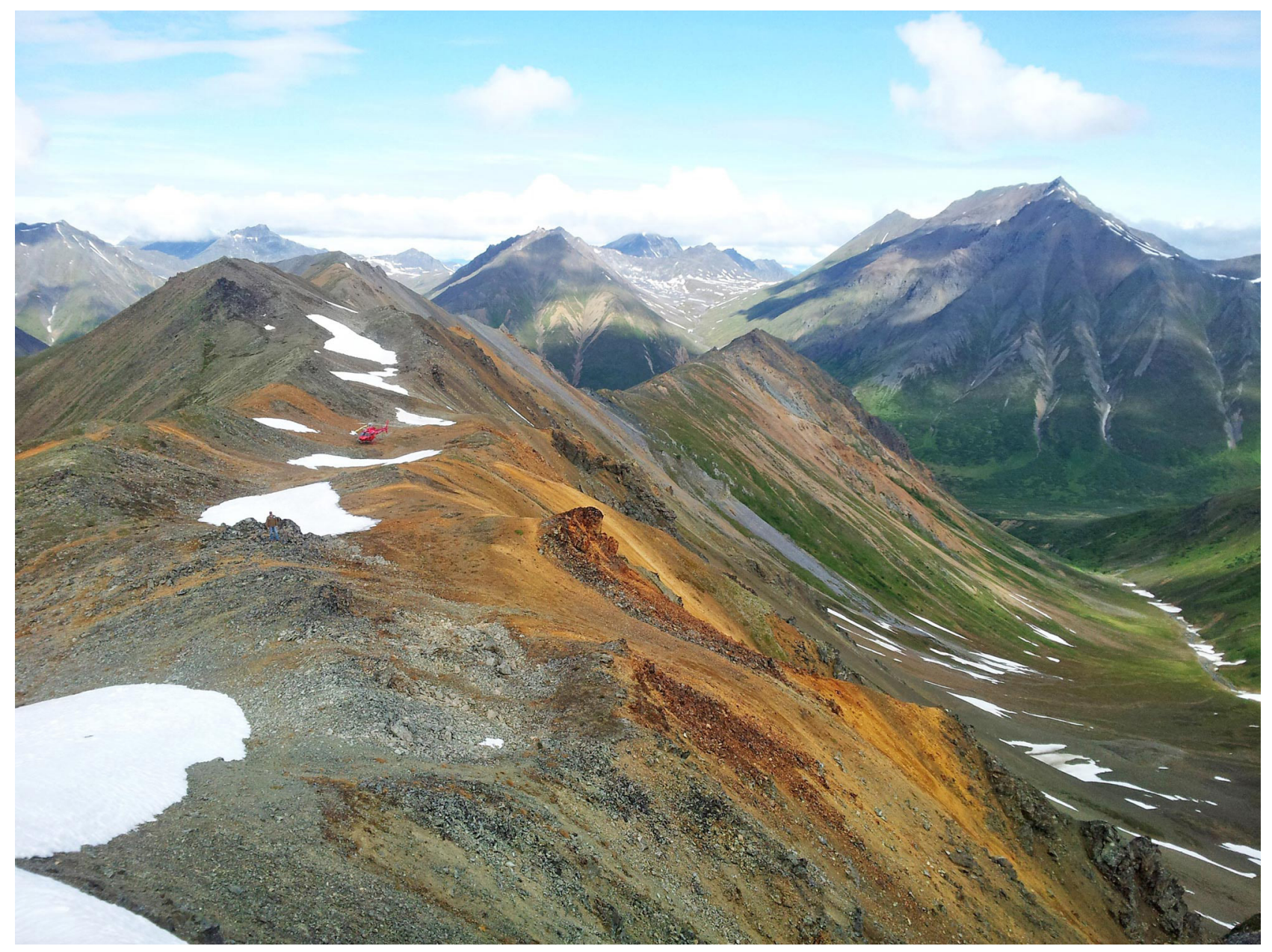

Photo 10. Senator prospect copper anomaly in gossan along the ridge, looking to the northeast. Early-stage exploration was conducted in 2017 at the recently discovered Senator sediment-hosted-copper prospect, part of PolarX's Alaska Range Project portfolio. Photo from: PolarX Ltd.; last accessed September 28, 2018; https://www. polarx.com.au/wp-content/uploads/2017/06/bg-5.jpg.

stockwork veins, and quartz-healed breccia in hornfelsed clastic sediments, which are locally cut by east-west-striking felsic dikes. Endurance collected 60 rock-chip samples from a trench oriented perpendicular to the strike of the gold-bearing structure; chip sampling averaged 0.0160 ounce of gold per ton over 30 feet (photo 11).

The Trout target on the Trout property is a northeast-southwest-trending shear zone hosted within syenomonzonite, which is spatially associated with a 3,000-foot by 1,000-foot, greater than 0.003 ounce of gold per ton, soil anomaly. In August 2017, Endurance collected 31 power-auger soil samples and 12 rock samples in the central part of the soil anomaly, and with mapping, Endurance outlined a 26- to 76-foot-wide, iron-oxidized, intrusion-hosted shear zone over a northeast-trending strike length of about 558 feet. The highest soil values include 0.068 and 0.061 ounce of gold per ton, and up to 0.121 ounce of silver per ton. Stibnite and arsenopyrite were observed in several rock samples.

Endurance collected 12 rock and nine soil samples at their Wolverine property in 2017. They found a narrow quartz vein with six visible gold grains hosted in a quartz-rich intrusion. Samples returned up to 0.3398 ounce of gold per ton.

\section{Red Mountain}

White Rock Minerals Ltd. completed review of their northern Alaska Range, Red Mountain polymetallic volcanogenic massive sulfide (VMS) 


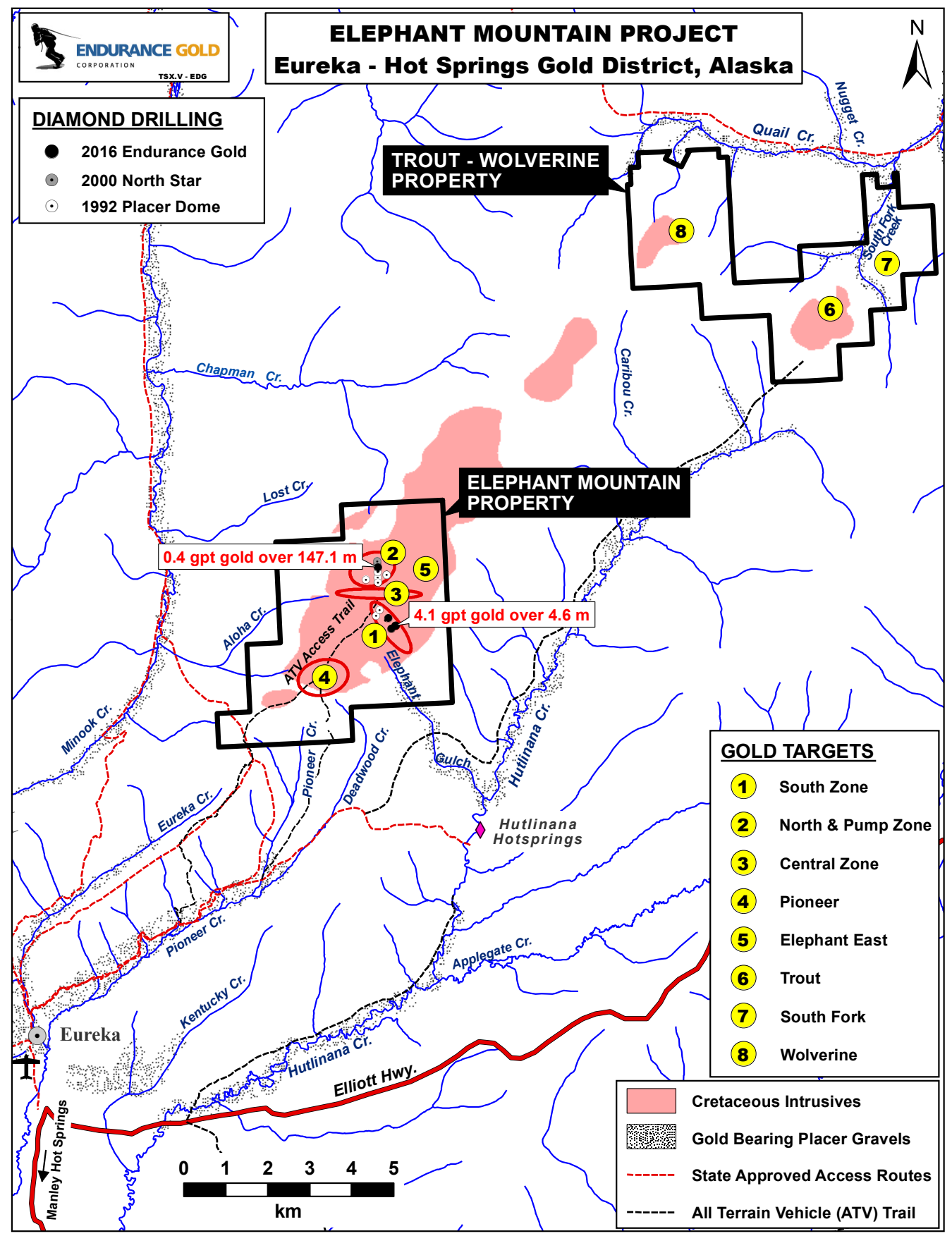

Figure 8. Map of Endurance Gold Corporation's Elephant Mountain project area. Figure source: Endurance Gold Corporation; last accessed October 22, 2018; http://www. endurancegold.com/s/elephant.asp?ReportID=838124\& Type=Elephant-Mountain-GoldProject-Alas...\& Title=Maps

project area's historical drilling database in February 2017, and followed it up with a historical core-resampling program. White Rock Minerals Ltd. announced a maiden, JORC-compliant mineral resource estimate for the Red Mountain area's two known VMS deposits: Dry Creek (101 historical drill holes for a total of 45,380 feet) and West Tundra Flats (26 historical drill holes for 17,550 feet). At a 3 percent cut-off grade, the main Dry Creek deposit contains an inferred resource of 2.6 million tons at 4.7 percent zinc, 1.9 percent lead, 0.2 percent copper, 2.0 ounces 
of silver per ton, and 0.012 ounce of gold per ton. At a 3 percent cut-off grade, the West Tundra Flats deposit contains an inferred resource of 7.4 million tons at 6.2 percent zinc, 2.8 percent lead, 0.1 percent copper, 5.51 ounces of silver per ton, and 0.032 ounce of gold per ton (appendix D).

\section{Richardson}

Northern Empire Resources Corp. released a NI43-101 technical report in January 2017, which contains new geological interpretations and recommendations for future exploration work at their Richardson property southeast of Fairbanks. The property hosts multiple intrusion-related and low- and high-angle fault-hosted lode gold prospects with gold \pm silver \pm arsenic \pm antimony \pm bismuth geochemical signatures, and geologic similarities to the Fort Knox and Pogo gold mines. The project area includes the historical Democrat lode gold mine hosted by a northwest-trending, 90 million-year-old, quartz-feldspar-porphyry dike. No exploration activities were conducted in 2017.

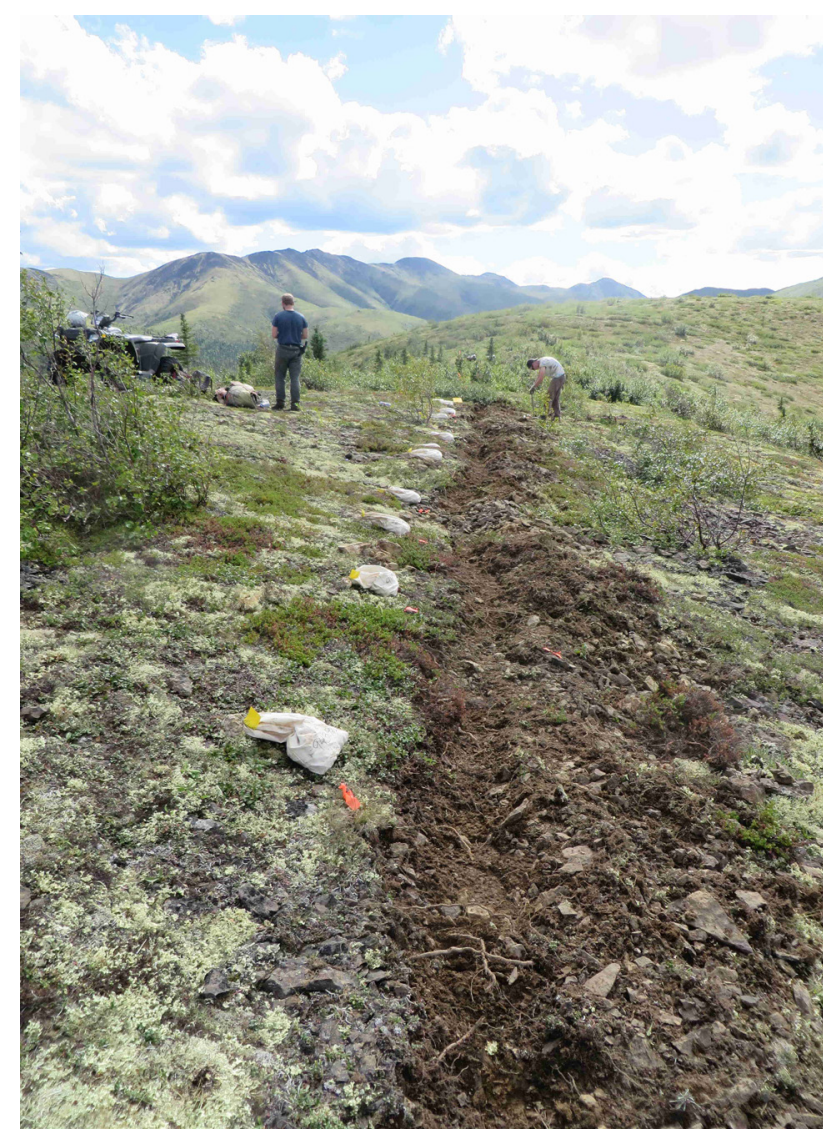

\section{Skippy-Fog}

Stone Boy Inc. conducted exploration on their Skippy and Fog gold properties in the Big Delta Quadrangle in 2017.

\section{Eastern Tanacross}

Kenorland Minerals recently staked claims in the eastern Tanacross Quadrangle; their project area covers the Taurus trend of porphyry coppergold-molybdenum-silver prospects (photo 12), as well as the Bluff, East Dennison, PushBush, and Big Creek prospects. In 2010 Senator Minerals stated an unofficial inferred mineral resource estimate for Taurus: 75 million tons grading 0.275 percent copper, 0.032 percent molybdenum, and 0.0048 ounce of gold per ton, which was based on 10 drill holes with an average spacing of 474 feet. In 2017 Kenorland's work program included collecting rock and soil-geochemical samples along ridgelines and spurs, documenting alteration, and mapping the location of volcanic and plutonic rocks. They identified a new area of alteration spatially associated with intrusive rocks on the east side of their property.

\section{Liberty Bell}

Millrock Resources Inc.'s Liberty Bell project 70 miles southwest of Fairbanks has geophysical signatures, numerous intermediate to felsic dikes, sills, and plugs, as well as widespread gold-plus-copper anomalies with tourmaline, which suggest the presence of high-level alteration-mineralization associated with a porphyry copper-gold system. In March 2017, Millrock entered into a joint-venture option agreement with Kinross Gold U.S.A., Inc., a subsidiary of Kinross Gold Corporation. In July 2017, Millrock Resources Inc. commenced a field program

Photo 11. Endurance Gold Corporation trench sampled a goldbearing structure at the South Fork target of the Trout property, east-northeast of Endurance's main Elephant Mountain property in interior Alaska. Mineralization occurred as oxidized sulfides with quartz veining, stockwork veins, and quartzhealed breccia. Photo from: Endurance Gold Corporation; last accessed September 28, 2018; http://www.endurancegold.com/ Elephant/Photos/2017\%20South\%20Fork\%20trench.jpg. 
at its Liberty Bell project. The project targets distal skarn gold deposits and possibly porphyry copper-gold deposits. Millrock collected more than 1,600 soil samples, as well as stream sediment and rock samples.

\section{Golden Zone}

Avidian Gold Alaska Inc.'s Golden Zone property, located midway between Anchorage and Fairbanks and accessed by a 10 -mile-long road off the main transportation route, contains numerous, Late Cretaceous, igneous-affiliated mineral occurrences. These occurrences are hosted in three, north-northeast-oriented fault blocks named, from northwest to southeast, the Golden Zone, Long Creek, and Silver Dikes corridors. The Golden Zone corridor includes the Breccia Pipe deposit with a total indicated and inferred resource of 6.11 million tons of material with 303,300 contained ounces of gold (appendix D), as well as the Riverside, Banner, Lupine, Bunkhouse, Mayflower, BLT, and GAS prospects (figure 9). The Long Creek corridor includes the Copper King, Long Creek, and South Long Creek prospects. The Silver Dikes corridor contains veins and shear zones associated with granitic dikes.

In 2017 Avidian completed 11 diamond drill holes in, and north of, the Breccia Pipe deposit, for a total of 8,458 feet (photo 13). An intercept of 219.8 feet grading 0.144 ounce of gold per ton was obtained from the Breccia Pipe deposit. Immediately outside the pipe, and outside the presently defined resource, Avidian intersected 164.0 feet grading 0.0213 ounce of gold per ton. One hole drilled into the BLT Zone, a 6,500-foot-long shear zone on the eastern margin of the breccia pipe, returned 315.0 feet grading 0.0155 ounce of gold per ton. Mineralization in conglomerate up to 1,600 feet north of the breccia pipe included 34.5 feet grading 0.0449 ounce of gold per ton and 124.6 feet grading 0.0300 ounce of gold per ton. Drill testing of IP anomalies sub-parallel to the main northeast-southwest structural trend

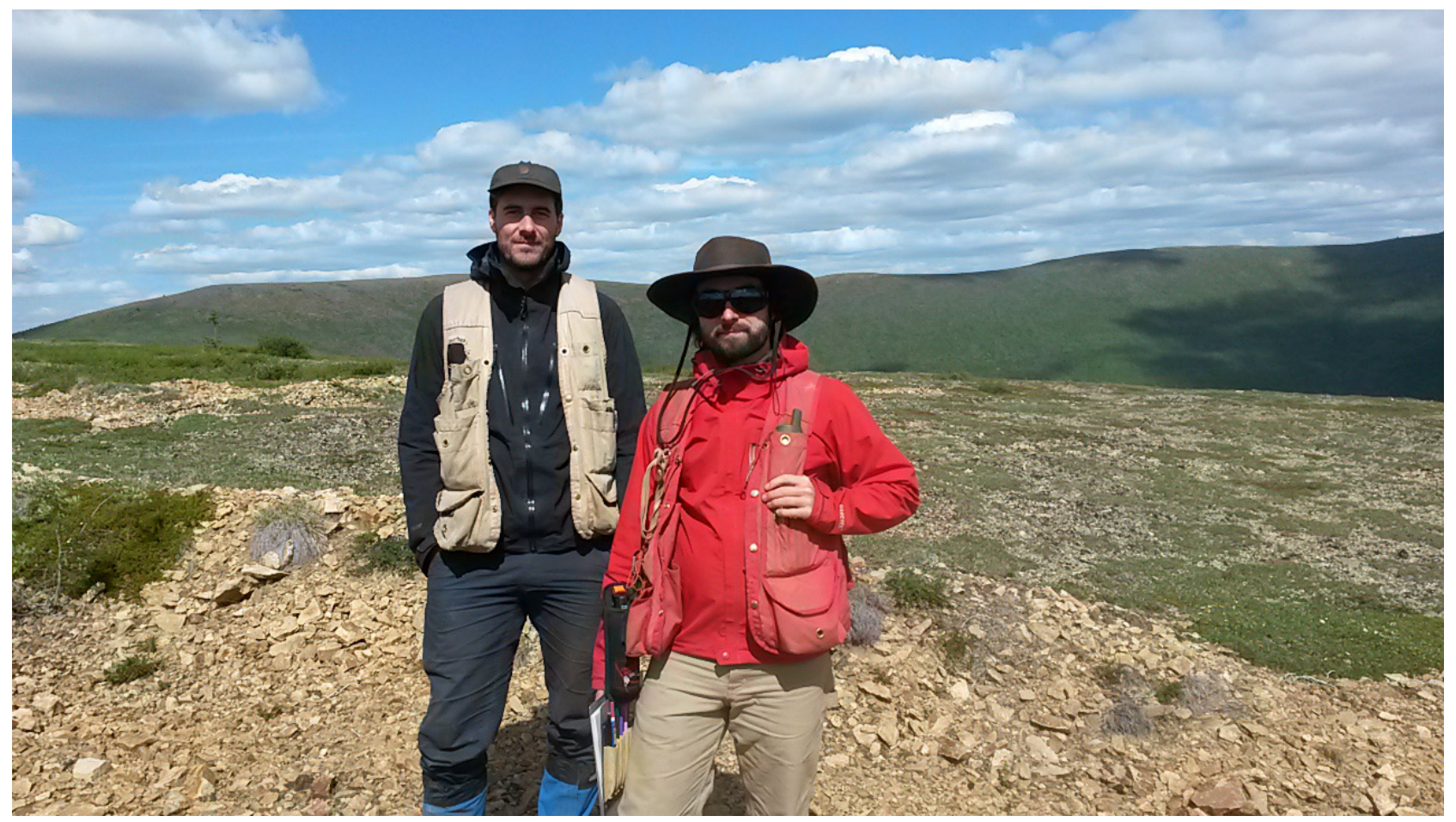

Photo 12. Zach Flood and Francis MacDonald from Kenorland Minerals conducted reconnaissance exploration in 2017 at the Taurus copper-gold-molybdenum-silver porphyry property, part of their Tanacross project. Photo courtesy of Jennifer Athey, DGGS. 
of the Breccia Pipe deposit area led to DDH GZ 17-10 intersecting 70.9 feet grading 0.0426 ounce of gold per ton in a previously unknown mineralized conglomeratic unit. This stratigraphic unit represents a substantial new exploration target on the property that has not been evaluated by drilling and is open in all directions. This conglomerate has never been evaluated along strike or drill tested. Mineralized conglomerate is also present at the Long Creek and Copper King prospects. The 2017 drill results confirm the potential to define additional resources in the neighborhood of the Breccia Pipe.

Avidian also completed 27-linemiles of time-domain Induced Polarization (IP) surveys over the Breccia Pipe deposit area, and the Riverside, Bunkhouse, Copper King, and South Long Creek prospects, using a variety of array and dipole separations. The IP dataset was integrated with a 1996 airborne magnetic and electromagnetic geophysical survey and a 1982 controlled-source audio magnetotelluric (CSAMT) survey. The combined surveys delineate coincident magnetic-low/resistive-high anomalies interpreted to represent intrusions. Airborne magnetic data also delineate structural trends on the property. Interpretation of these geophysical surveys, along with field geological work, helped target many of the 2017 drill holes. Highlights of geophysical interpretations include: mineralization at Breccia Pipe West, Breccia Pipe deposit, Bunkhouse, and Mayflower is found along the eastern edge of a prominent resistivity high (interpreted

Figure 9. Map of prospects on Avidian Gold Alaska Inc.'s Golden Zone property. Figure source: Avidian Gold Corporation; last accessed October 22, 2018; intrusion) in the 1982 CSAMT data; at Riverside, Breccia Pipe, Bunkhouse, and Copper King, pronounced chargeability anomalies were delineated over strike lengths in excess of 1,600 feet; Avidian's 2017 IP survey identified multiple anomalies sub-parallel to the main northeast-southwest structural trend of the Breccia Pipe deposit area; in the Copper King and Long Creek areas, magnetic-low features are interpreted to be shallow intrusions adjacent to known mineralization, which have associated chargeability highs; at South Long Creek, one 6,500-foot-long reconnaissance IP line

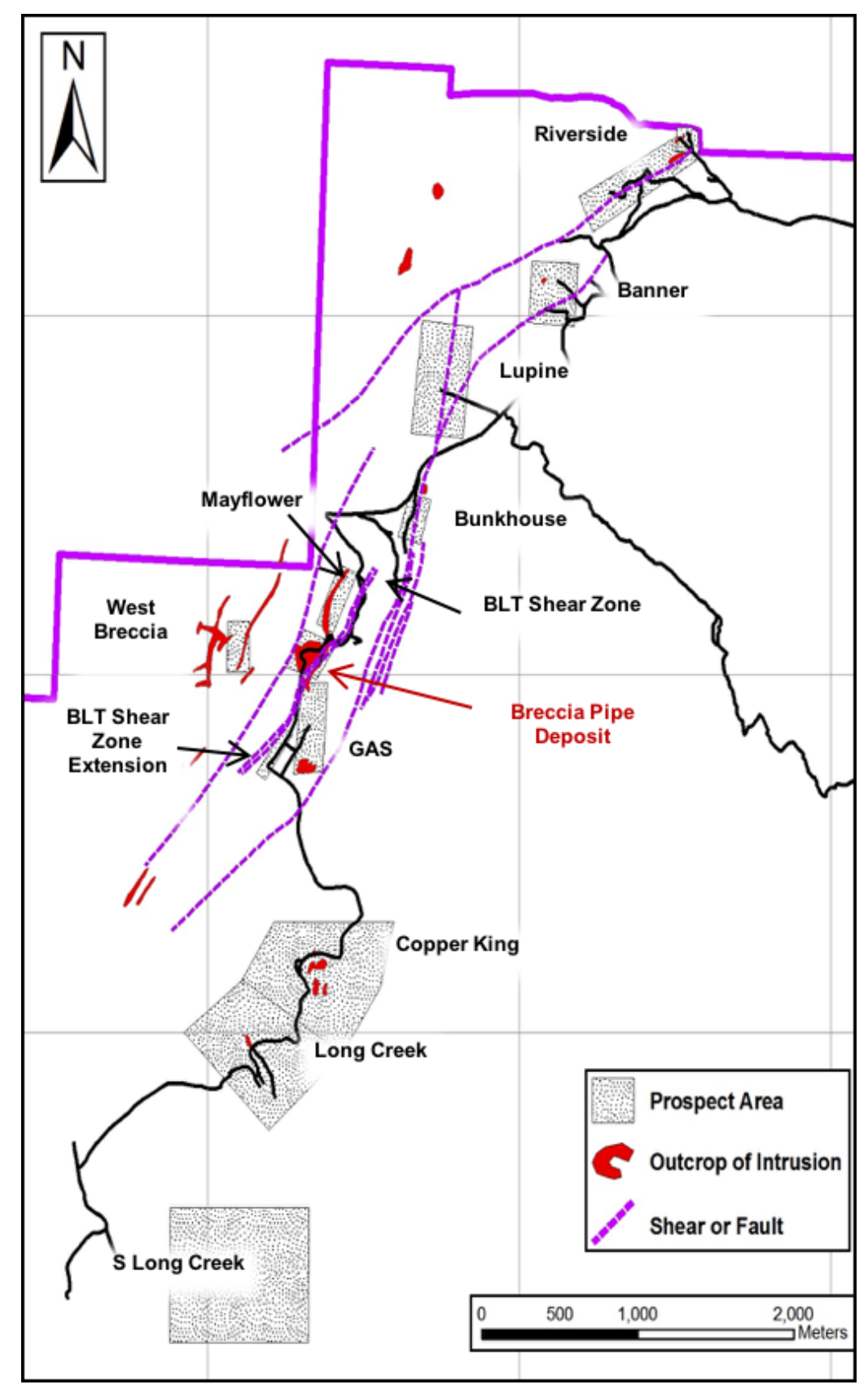




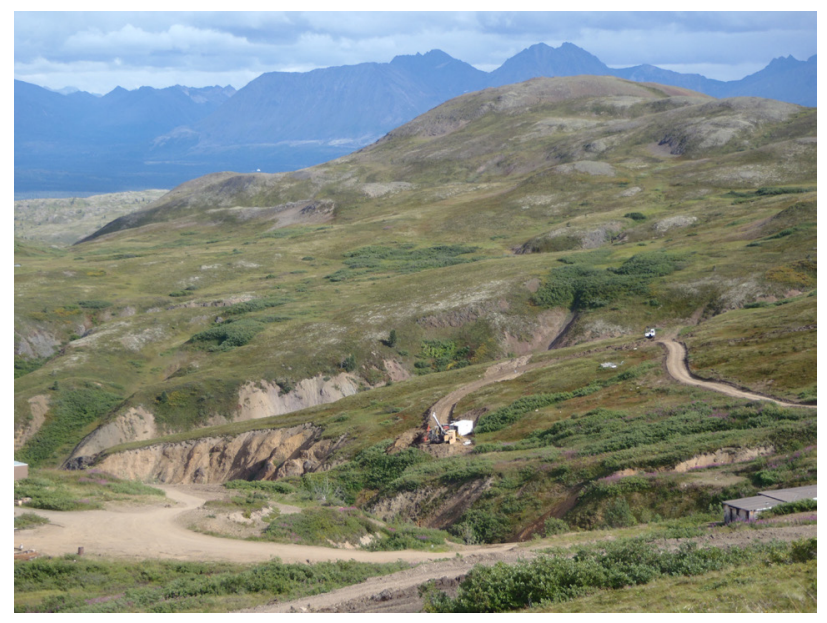

Photo 13. 2017 drill results at Avidian's Golden Zone property extended the mineralized zone outside of the Breccia Pipe deposit area. Golden Zone is located 200 miles north of Anchorage and 10 miles west of the main highway corridor between Anchorage and Fairbanks. Photo courtesy of Tom Setterfield, Avidian Gold Alaska Inc.

was completed. Multiple anomalies were identified, with the most significant anomaly coincident within the main area of known mineralization.

Avidian's 2017 surface sampling program comprised 175 trench samples, 752 surface grab samples, and 155 soil samples; they also conducted geologic mapping. The 2017 results, combined with historical sampling and drilling, define a 5-mile-long strike length of gold mineralization grading greater than 0.0292 ounce of gold per ton within the northeast-trending Golden Zone and Long Creek corridors. The highest values obtained in 2017 (on different samples) were 1.41 ounces of gold per ton, 32.5 ounces of silver per ton, 2.72 percent copper, 13.65 percent lead, and 7.14 percent zinc.

The Golden Zone Corridor sampling program discovered a new mineralized breccia, termed Breccia Pipe West, approximately 1,600 feet west of the known Breccia Pipe deposit. Mineralized grab samples returned values ranging up to 0.427 ounce of gold per ton and up to 10.4 ounces of silver per ton, plus base metals, over an area of 650 feet by 160 feet. Breccia Pipe West is proximal to a 5,000-foot-long feldspar-biotite porphyry and has a coincident northeast-southwest-trending chargeability/ resistivity anomaly that has not been drill tested. A trench at Riverside returned 179.8 feet at 0.015 ounce of gold per ton.

Avidian's Copper King, Long Creek, and South Long Creek occurrences contain gold as well as some of the strongest copper mineralization found on the property. Mineralization in these occurrences collectively can be traced in excess of 6,500 feet, and the Long Creek corridor remains under-explored to the northeast and southwest. At Copper King, mapping indicates mineralization is proximal to a quartz-eye porphyritic granite exposed over 650 feet in strike length. Gold and base-metal mineralization occurs as: semi-massive sulfide in skarn; disseminated chalcopyrite and molybdenite in quartz-eye porphyritic granite; mineralization proximal to a quartz-stockwork granite returned 0.14 ounce of gold per ton, 3.09 ounces of silver per ton, and 1.41 percent copper from a grab sample, which is adjacent to an IP chargeability high; disseminated chalcopyrite in a conglomeratic unit (grab sample with 0.0440 ounce of gold per ton, 1.95 ounces of silver per ton, and 1.05 percent copper); chalcopyrite associated with a mafic dike (grab sample with 0.0420 ounce of gold per ton, 2.55 ounces of silver per ton, and 3.29 percent copper); and chalcopyrite stringers in siltstones. A trench in mineralized conglomerate at the Long Creek occurrence yielded 20.0 feet grading 0.403 ounce of gold per ton, 1.00 ounce of silver per ton, and 0.85 percent copper. This exposure is located approximately 3,300 feet south of the conglomeratic unit(s) at the Copper King showing. At South Long Creek, an assay of 0.321 ounce of gold per ton, 75.4 ounces of silver per ton, 0.24 percent copper, 14.3 percent lead, and 2.54 percent zinc was obtained from a grab sample of an arsenopyrite-quartz-carbonate vein proximal to quartz-eye porphyritic granite dikes.

\section{Honolulu}

The Honolulu property, located 5 miles east of the Parks Highway in south-central Alaska, hosts a silver-lead-zinc-copper-gold mineralized 
structural zone. In 2017 Honolulu Prospect Corp. conducted a two-month surface-sampling program, which included the collection and analysis of 1,003 rock samples from a major ridgeline on the project claim group.

\section{Valdez Creek Lode}

The Valdez Creek Lode, controlled by Valdez Creek Mining LLC, is the source of the Valdez Creek gold placers in the south-central Alaska Range. Prior exploration by CanAlaska identified five, vertically stacked, gold-bearing zones over a vertical distance of 600 feet with a strike length of over 900 feet. In 2017 Valdez Creek Mining completed a 24-hole core drilling program totaling 19,988 feet, plus hand trenching and geochemical sampling.

\section{Shalosky-Hi-Low-Hunter}

Rhyolite Resources Ltd. continued to raise working capital and exploration funds for their Paxson project 30 miles southwest of Tok. The project area includes the Shalosky, Hi-Low, and Hunter structurally controlled gold-bearing quartz vein systems drilled by Rhyolite in 2011 and 2012 (photo 14). The Alaska Division of Geological \& Geophysical Surveys released airborne geophysical data for the region in 2015 and published a geological map covering the area in 2017. In 2017 Rhyolite Resources Ltd. conducted prospecting and geological mapping in the project area.

\section{Emerick}

Northridge Exploration conducted geologic mapping, soil and rock sampling, trenching, and reclamation work near the Emerick prospect in the central Alaska Range in 2017.

\section{Delta}

Agnico Eagle Mines Limited evaluated select areas on their 100-percent-owned Delta volcanogenic massive sulfide project in the northern Alaska Range to identify targets for future drilling, and completed an updated resource estimate on the properties previously drilled VMS deposits. Between January and August, 2017, Agnico Eagle performed geologic field work, surface sample collection and analysis, 3D geologic modeling, and future drill-hole planning.

\section{Tibbs}

Tectonic Resources, LLC conducted exploration on their Tibbs project in the Big Delta Quadrangle in 2017. Work included geochemical sampling, gridding, hand trenching, and satellite imagery interpretation.

\section{SOUTH-CENTRAL REGION}

\section{Lucky Shot}

The Lucky Shot orogenic gold vein project, which includes the Lucky Shot and War Baby historical gold mines, is located 75 miles north of Anchorage in the Willow Creek mining district; gold was last mined on a small scale in the early 1990's. In April 2017, Miranda Gold Corp. filed an updated preliminary feasibility study (PFS) NI43-101 technical report for the Lucky Shot project, a joint venture between Gold Torrent Inc. and Miranda Gold Corp. The updated measured and indicated resource, at a cut-off grade of 0.146 ounce of gold per ton, is 227,700 tons at an average grade of 0.534 ounce of gold per ton $(121,500$ ounces of gold) and 0.0525 ounce of silver per ton (12,100 ounces). The inferred resource is 65,000 tons at an average grade of 0.540 ounce of gold per ton (35,100 ounces of gold) and 0.044 ounce of silver per ton (2,900 ounces of silver). The proven and probable reserve, internal to the resource, at a cut-off grade of 0.20 ounce of gold per ton and 34 percent mine dilution, is 192,200 tons at 0.455 ounce of gold per ton $(87,504$ ounces of gold) and 0.048 ounce of silver per ton (9,244 ounces of silver) (appendix D). In their PFS mine plan, stopes would be mined using either the open stull stope or waste-pillar mining method. The project is forecast to produce 79,114 ounces of gold in 5 years of production, with production of 25,645 ounces per year at peak production. Net cash flow before taxes for the same operating period is forecast to be $\$ 14,693,746$, with all-in sustaining costs of $\$ 675$ per ounce. As of October 2017, Gold Torrent completed the mill building's framework and other 
infrastructure projects, and continued refurbishing the portal area and widening the existing Enserch adit, with 773 feet completed. Gold Torrent completed a revised schedule and total-cost estimate to complete Lucky Shot development and determined the project will experience a 40 percent capital-cost increase, while the estimated planned gold production is projected to increase from 10,000 ounces to 20,000 ounces for 2019, and from 16,000 ounces to 25,000 ounces for 2020, an update from their June 2016 PFS. The total capital costs estimated to achieve commercial production, based on the earlier PFS, were $\$ 18.5$ million; the revised estimate is now $\$ 26.2$ million. In November 2017, Gold Torrent entered into a letter of intent with Miranda U.S.A., Inc., where Gold Torrent agreed to purchase Miranda's 30 percent ownership of and interest in Alaska Gold Torrent, LLC (AGT); Gold Torrent holds the other 70 percent.

\section{Opal}

The Opal gold-silver prospect, located in the headwaters of Liberty Creek, near Chitina, Alaska is being evaluated by Ben Porterfield. High-angle, gold-bearing, polymetallic quartz veins cut an Eocene sill, which intrudes schist of the Liberty Falls Terrane. The sill is intensely altered and contains abundant coarse-grained muscovite. The quartz veins are high-angle, typically less than a foot wide, and occur in sub-parallel sets. Minor galena occurs in the veins along with sphalerite, pyrite, and arsenopyrite. Vein samples assay up to multiple ounces of gold; visible gold is common. In 2017 a two-ton sample was collected, crushed, pulverized, and concentrated in preparation for further metallurgical tests.

\section{Icy Cape}

The Icy Cape gold and heavy mineral beachplacer property, located in the Gulf of Alaska

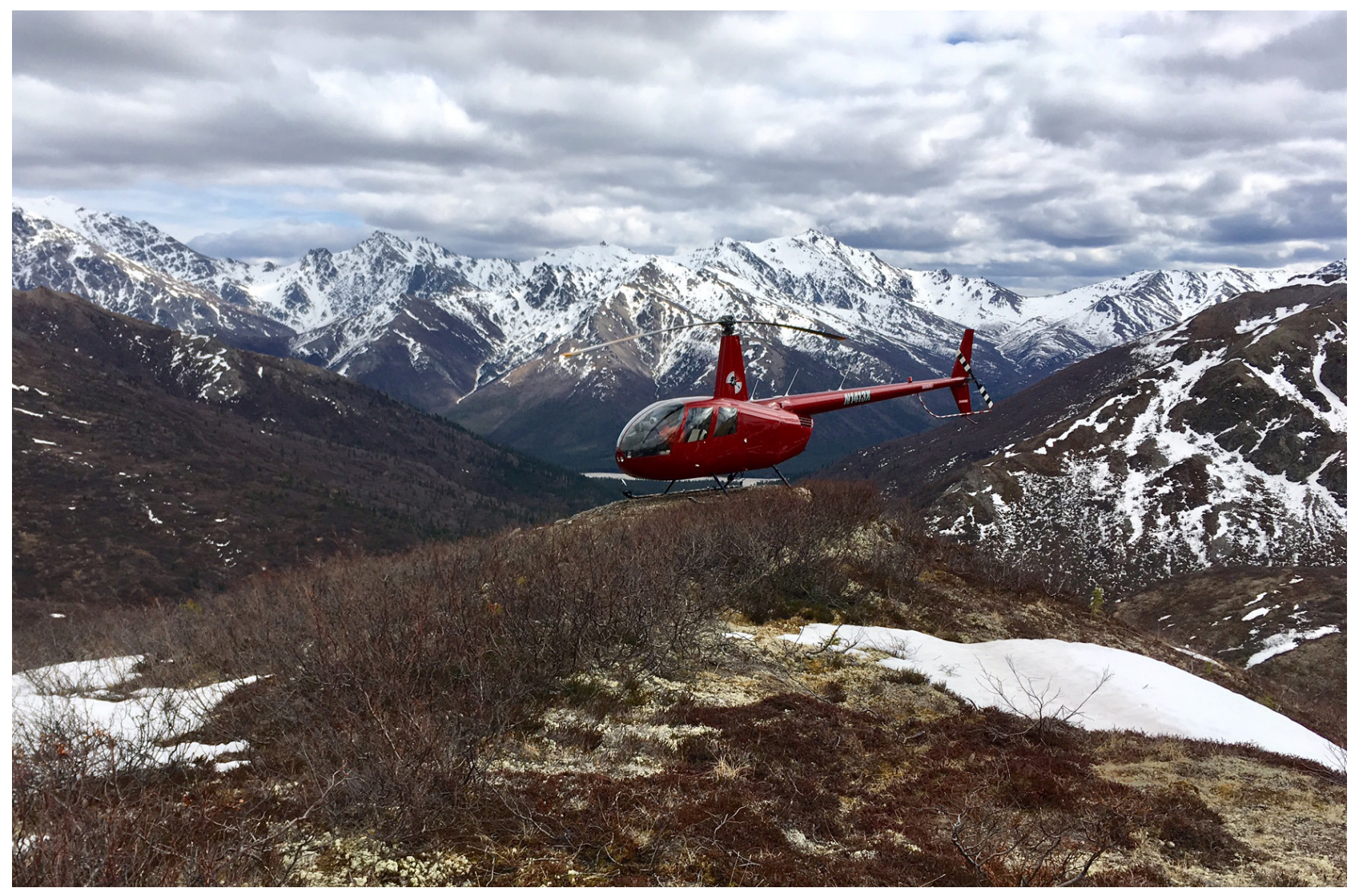

Photo 14. Rhyolite Resources Ltd. conducted prospecting for gold targets and geological mapping in their Paxson project area in 2017. Photo courtesy of Richard Graham, Rhyolite Resources Ltd. 
near Icy Bay about 75 miles northwest of Yakutat, is owned by the Alaska Mental Health Trust Authority and managed by the Trust Land Office (TLO). The area has been explored and mined for placer gold since the early 1900s. In 2015 TLO initiated their Icy Cape Gold and Industrial Heavy Minerals project, a staged, incremental effort to evaluate the potential for producing industrial heavy minerals (garnet, zircon, rutile, and epidote-group minerals) as part of a placer gold operation. During investigations to date, TLO has identified platinum-group metals in heavy mineral concentrates, tested garnet concentrates as abrasive media (they met industry standard SSPC-AB1; photo 15), and is in the process of testing epidote-group minerals as abrasive media and for water filtration and purification uses. Additional mineralogical and metallurgical test work on gold and heavy mineral separation and recovery methods are ongoing.

In 2017 TLO published a gold- and heavy-minerals study, including particle-size-distribution analyses, and modal-mineral counts of magnetic fractions; heavy minerals excluding gold (garnet, magnetite, ilmenite, rutile, and zircon) average 7.9 percent (in a range of 1.0-37.6 percent), along with trace uraninite, thorite, monazite, and xenotime. X-ray diffraction, X-ray fluorescence, scanning electron microscopy, and microprobe analysis were used to confirm petrographic mineral determinations and to obtain detailed compositions of minerals and inclusions. TLO interprets the high variability in the textures, heavy mineral content, and compositions of the Icy Cape-area sediments as a probable function of depositional environment.

In 2016 TLO contracted for a low-altitude, high-resolution aeromagnetic survey over the Icy Cape property. Magnetic-high anomalies were interpreted to be associated with heavy mineral concentrations, and along with geologic models, were used to help locate drill targets. Follow-up work in 2017 included stratigraphic-framework and resource-assessment drilling totaling about 7,500 feet of 8-inch-diameter sonic core (photo 16). TLO confirmed that beach sediments are present from the current shoreline to almost 3 miles inland, where ancient beach sediments occur in coast-parallel terraces; gold-, garnet-, and epidote group mineral-bearing sequences were located in stacked shorelines over 200 feet above sea level. Drilling focused on the region between the eastern property boundary and the Little River to the west along the main road and old logging roads, and gold and heavy-mineral-bearing sands were encountered below geophysical targets. Select samples were shipped to a contracted heavy mineral laboratory to be analyzed for critical economic components (heavy mineral and gold grade, mineral assemblages, quality of mineral species, and particle-size distribution).
Photo 15. Photo of garnet-bearing heavy mineral concentrate from Icy Cape, northwest of Yakutat in the Gulf of Alaska. The beach-placer property, owned by the Alaska Mental Health Trust Authority, is being explored by the Trust Land Office. Photo courtesy of Alexandra Busk, DGGS.

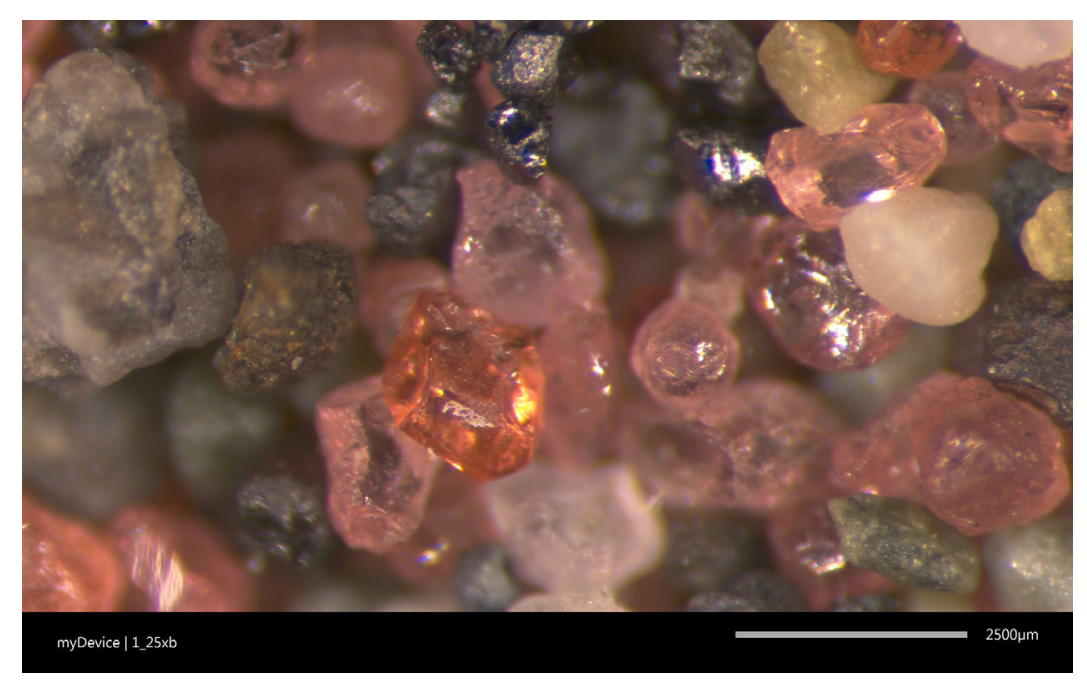




\section{SOUTHWESTERN REGION}

\section{Donlin}

Donlin is a proposed, large open-pit gold mine located in southwest Alaska, which is owned by Donlin Gold, LLC, a 50/50 partnership between Barrick Gold Corp. and NovaGold Resources Inc. In June 2017, Donlin Gold, LLC approved an $\$ 8$ million drill program budget. The program included 16 holes for a total of 23,097 feet (photo 17), and reported highlights include: mineralized intercepts encountered higher grades than predicted by previous modeling; distinct, significant, high-grade zones were intercepted in multiple areas; and high-grade mineralization was intercepted at depth in the ACMA deposit in an area of sparse drilling. The additional geochemical and structural data collected as part of the drill program will strengthen understanding of the mineralized zones and structural controls. Also, ongoing optimization work will assess selective mining methodology to potentially further improve mined grades and will consider opportunities to reduce initial capital-cost outlays. Donlin Gold, LLC plans to incorporate these data into the resource model, and optimization efforts and results from the 2017 drill program will be used to update the Donlin Gold project's 2011 feasibility study in the future.

\section{Pebble}

The Pebble porphyry copper-gold-molybdenum deposit in southwestern Alaska is currently one of the world's most significant undeveloped

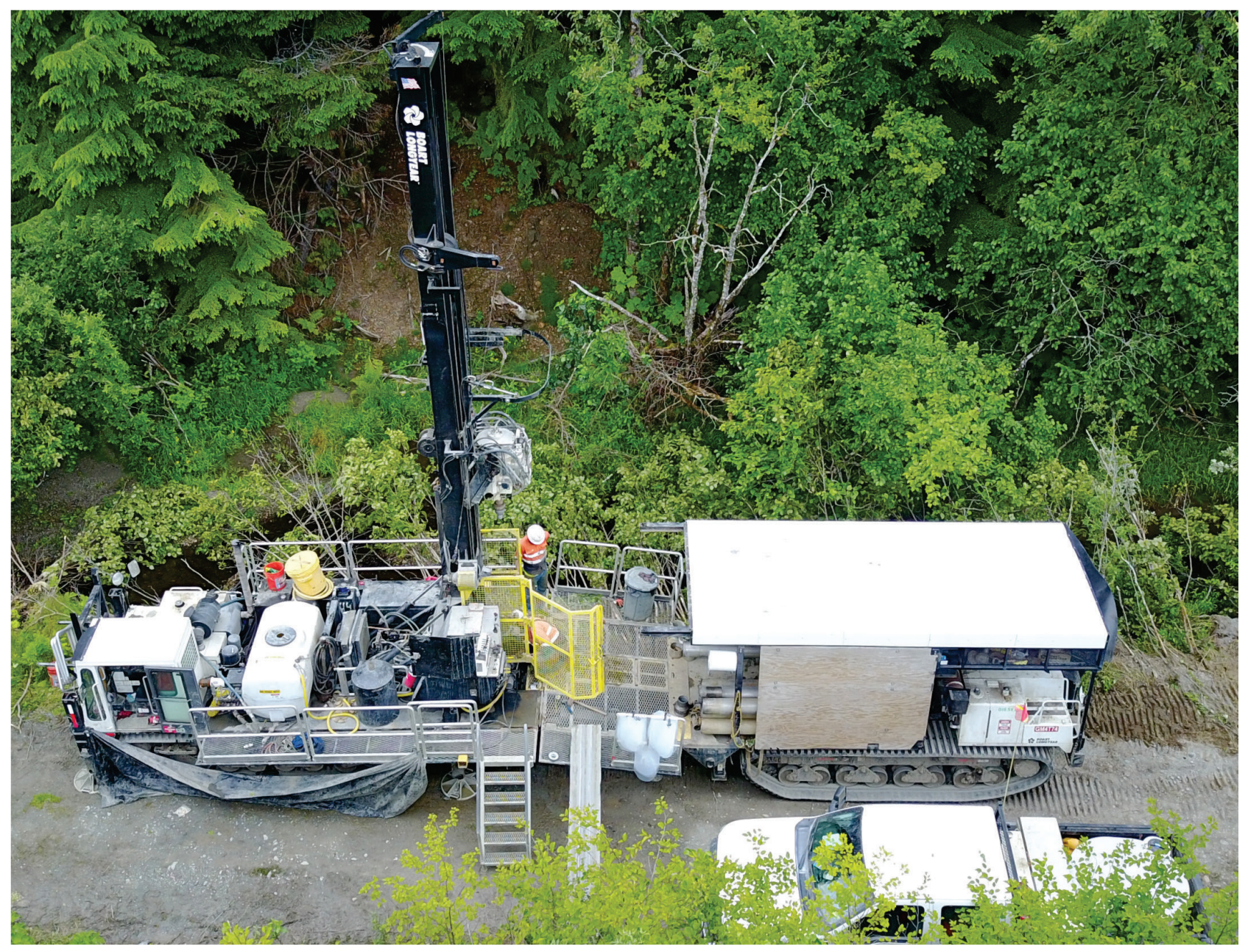

Photo 16. Boart Longyear's LS600 sonic drill rig in action at Icy Cape in the Gulf of Alaska, collecting 2.5-foot-long, 8-inch-diameter samples of beach placer. Photo courtesy of Karsten Eden, Trust Land Office. 
deposits of copper, gold, and molybdenum, with a total endowment of 81.8 billion pounds of copper and 107.9 million ounces of gold contained in 12 billion tons of ore material grading 0.34 percent copper, 0.0235 percent molybdenum, 0.009 ounce of gold per ton, and 0.044 ounce of silver per ton (appendix D). The Pebble Limited Partnership (PLP) has invested more than $\$ 750$ million in the Pebble project, principally on geological, environmental, engineering, and other technical studies aimed toward the development of the mine plan and permit applications.

In May 2017, PLP announced an agreement with the U.S. Environmental Protection Agency (EPA) to resolve the long-standing preemptive actions taken by the EPA against the Pebble project. The EPA agreed to initiate a process to withdraw its proposed determination under Section 404(c) of the Clean Water Act (CWA), thereby clearing the way for Pebble to apply for a CWA 404 permit with the U.S. Army Corps of Engineers and allowing PLP to initiate the normal permitting process under the CWA and the National Environmental Policy Act (NEPA) and

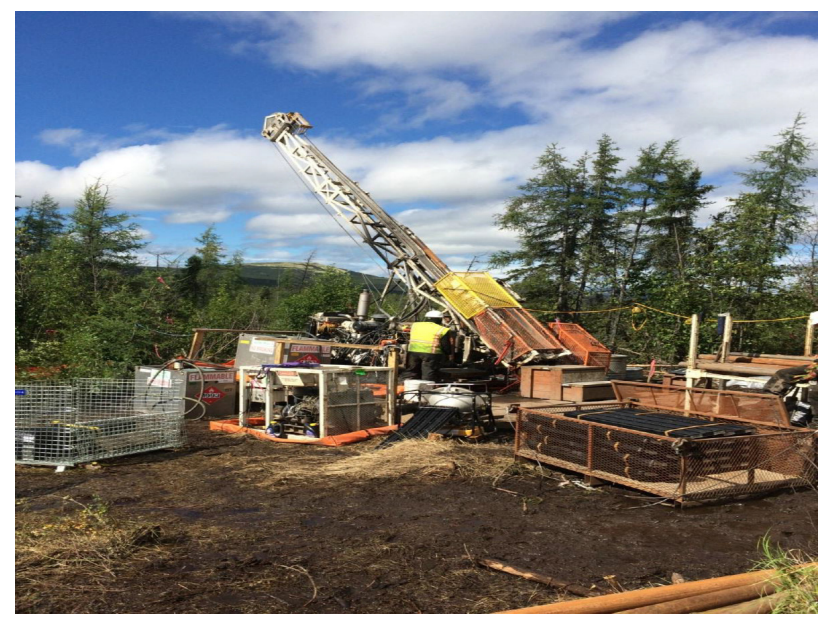

Photo 17. Donlin Gold, LLC conducted a 16-hole drilling program to improve on their resource model and feasibility study, as the project nears the end of the permitting process. Photo from: NovaGold Resources Inc., October 4, 2017, 2017 third quarter \& project update; last accessed September 28, 2018; http://www. novagold.com/ resources/presentations/2017-10-04 NGPPT Q3-2017 FINAL.pdf. to start advancing the Pebble project to the next phase of development. In July 2017, EPA initiated steps to withdraw its proposed determination restricting development at the Pebble project.

In October 2017, PLP presented new development concepts for Pebble to address stakeholder concerns. These include reducing the footprint of the project's major mine facilities (open pit, tailings storage facility) to roughly 5.9 square miles, about half of the prior envisioned size. Mine operations in the salmon-bearing Upper Talarik River watershed region would be eliminated. Tailings-storage facilities (TSF) would be constructed with enhanced buttresses and slopes. Potentially acid-generating tailings would be separated from other tailings and stored in a lined TSF, which would be restricted to the North Fork Koktuli River area. The project no longer proposes the use of waste rock piles or cyanide in the metal-recovery process. Using a ferry route across Iliamna Lake would reduce the total road area, stream crossings, bridges, and culverts to minimize the project's impact on local wetlands. Mine infrastructure would be designed to withstand the greatest scientifically predicted seismicity. Under this scenario, the proposed Pebble mine would have a projected operating life of 20 years.

In December 2017, Northern Dynasty Minerals Ltd. announced its wholly-owned US-based subsidiary Pebble Limited Partnership filed for a U.S. Clean Water Act 404 permit with the U.S. Army Corps of Engineers on December 22, 2017, thereby initiating Federal and State permitting for the Pebble project under NEPA. On December 18, 2017, Northern Dynasty announced a framework agreement with First Quantum Minerals Ltd., which contemplates a future option agreement and investment in the Pebble Partnership. Northern Dynasty received an initial $\$ 37.5$ million early option installment payment from First Quantum.

\section{Luna, Luna East-Quicksilver-Kisa}

Riversgold Ltd. acquired mineral claims over the Luna, Quicksilver, Luna East, and Kisa properties, 81 miles south of Aniak in southwest 
Alaska, through the purchase of Afranex Gold Ltd. in 2017. In the general area, Cretaceous Kuskokwim Group marine sediments were intruded by Late Cretaceous and Tertiary plutons, volcanic-plutonic complexes, and extensive dike and sill swarms. The project area contains 12 miles of strike of the North Fork fault (a mineralized, subsidiary splay of the Denali-Farewell fault) and the North Fork granite pluton, which has intruded and locally hornfelsed Kuskokwim Group black shale. Mineralization in the project area is characterized by outcropping high-grade gold \pm polymetallic mineralization at the Quicksilver, Luna, and Luna East prospects along the North Fork fault. Historical assays of rock outcrops at Quicksilver yielded up to 1.09 ounces of gold per ton and 1.69 ounces of silver per ton; Luna rock chips contain up to 1.89 ounces of gold per ton and 2.16 ounces of silver per ton; and rock chips from a Luna East massive sulfide outcrop yielded up to 1 percent copper, 2.63 ounces of silver per ton, and 0.029 ounce of gold per ton. Their nearby Kisa project hosts a large mineralized breccia, along with a series of mineralized felsic porphyry dikes. Five prior diamond holes drilled in 2007 intersected wide zones of gold mineralization.

Riversgold Ltd. completed a detailed helicopter-based magnetic survey in 2017; it shows a large magnetic high adjacent to the North Fork granite, which is interpreted to represent skarn-related mineralization. Approximately 342 line-miles of the airborne survey was flown over Luna, infilling a prior magnetic and electromagnetic survey flown in 2006-2007 by Kisa Gold Mining Inc.

\section{Groundhog}

The early exploration-stage, Groundhog porphyry copper project is a 40,000 -acre property located on State of Alaska claims 200 miles southwest of Anchorage; it is owned by Chuchuna Minerals Company and is currently under option to Quaterra Resources, Inc. The property covers the northern extension of a 6-mile-wide, north-northeast-trending structural zone that hosts the Pebble porphyry copper-molybdenumgold deposit, approximately three miles south of the Groundhog claim boundary. Regional magnetic data suggest geology similar to that at Pebble may extend under cover an additional 18 miles northeast from Pebble.

\section{Quaterra Resources, Inc.'s drilling at} Groundhog tested several IP anomalies identified both by historical IP surveys and new IP surveys completed during June and July 2017. The anomalies are located under shallow Tertiary volcanic cover and glacial till. Quaterra's drilling consisted of four widely-spaced core holes, totaling 4,073 feet, which were drilled over an area approximately six miles north-south by three miles east-west. DDH 3/3A encountered propylitically altered gabbro, pyroxenite, and basalt basement rocks. The strongly altered and pyritized core was uniformly anomalous in copper $(0.0025$ to 0.0612 percent), with scattered anomalous molybdenum (trace to 0.0177 percent) and gold (trace to 0.0241 ounce of gold per ton). DDH 4, collared approximately six miles south of DDH 3 , encountered variably pyritized and silicified, multi-phase intrusive porphyry rocks with weakly anomalous copper and zinc values over its entire length. The dominant rock was quartz-plagioclase-potassium feldspar porphyry, which was intruded by a more altered and mineralized feldspar porphyry, both of which were intruded by a late unmineralized intrusive breccia. $\mathrm{DDH}$ 1 and DDH 2, drilled approximately three miles apart and midway between DDH 3 and DDH 4, intersected weak sulfide mineralization, currently interpreted as Tertiary epithermal mineralization and syngenetic pyrite, respectively.

\section{SOUTHEASTERN REGION}

\section{Greens Creek}

Hecla Mining Company spent $\$ 4.265$ million on exploration in 2017 at their Greens Creek underground volcanogenic massive sulfide mine in southeast Alaska. Exploration and definition drilling continue to identify and refine resources, keeping reserves well ahead of production (photo 
18). Exploration drilling, including 20,502 feet of surface exploration and 26,674 feet of underground exploration core drilling, focused on the East Ore, West, Deep 200 South, 5250, and Gallagher zones (figure 10). Definition drilling, totaling 129,715 feet, refined the resources of the East Ore, Deep SW, Deep 200 South, Gallagher, 9A, NWW, SW, SW Bench, West, and Upper Plate ore zones.

In the first quarter of 2017, Hecla's drilling refined resources of the 9A, NWW, Upper Southwest, East Ore, and West zones for possible conversion to reserves. 9A Zone drilling yielded one intersection with 52.1 ounces of silver per ton, 0.03 ounce of gold per ton, 10.5 percent zinc, and 5.3 percent lead over 21.7 feet. Drilling of the southern extension of the NWW Zone continues to define mineralization along the lower fold, spanning from the fold nose and along the upper limb. Mineralization is represented by multiple distinct bands of massive ores and mineralized argillites; one intersection yielded 87.1 ounces of silver per ton, 0.32 ounce of gold per ton, 15.4 percent zinc, and 7.5 percent lead over 27.9 feet. Upper Southwest Zone drilling identified mineralization that extends north of previous mining in the zone and down to the upper limb of the NWW Zone. Assay results include 35.0 ounces of silver per ton, 0.02 ounce of gold per ton, 5.9 percent zinc, and 3.2 percent lead over 15.0 feet.
East Ore Zone drilling indicates a "pinch and swell" configuration; one intersection included 33.8 ounces of silver per ton, 0.11 ounce of gold per ton, 3.2 percent zinc, and 1.0 percent lead over 11.9 feet. West Zone drilling suggests mineralization is of similar extent and thickness along the nose and eastern limb. An extension to the resource has been identified adjacent to the Maki Fault and is open at depth and along strike.

In the second quarter, Hecla's drilling refined resources of the East Ore, NWW, Upper Plate, and West zones for possible conversion to reserves and assay results were also received from prior 9A and Deep Southwest drilling. One East Ore Zone intersection yielded 26.7 ounces of silver per ton, 0.10 ounce of gold per ton, 10.0 percent zinc, and 5.4 percent lead over 5.6 feet. Exploration drilling immediately west of the East Ore Zone in the Klaus Shear structure also identified new mineralization. West Zone drilling suggests resource additions along the nose and eastern limb as well as along the Maki Fault; one intersection yielded 643.5 ounces of silver per ton, 1.8 ounces of gold per ton, 14.9 percent zinc, and 7.8 percent lead over 4.8 feet. One 9A Zone intersection yielded 10.4 ounces of silver per ton, 0.04 ounce of gold per ton, 11.3 percent zinc, and 2.2 percent lead over 45.0 feet. These resources are immediately available to existing ramps. Deep Southwest Zone drilling identified mineralization that extends
Photo 18. Roof bolter at Hecla's

Greens Creek mine prepares the underground area for additional work. More than half of exploration drilling at Greens Creek occurred underground in 2017. Photo source: Hecla Mining Company; last accessed September 28, 2018; https://www.hecla-mining.com/ wp-content/uploads/2015/11/HeclaGreensCreek-12 DSC2326a@2x.jpg.

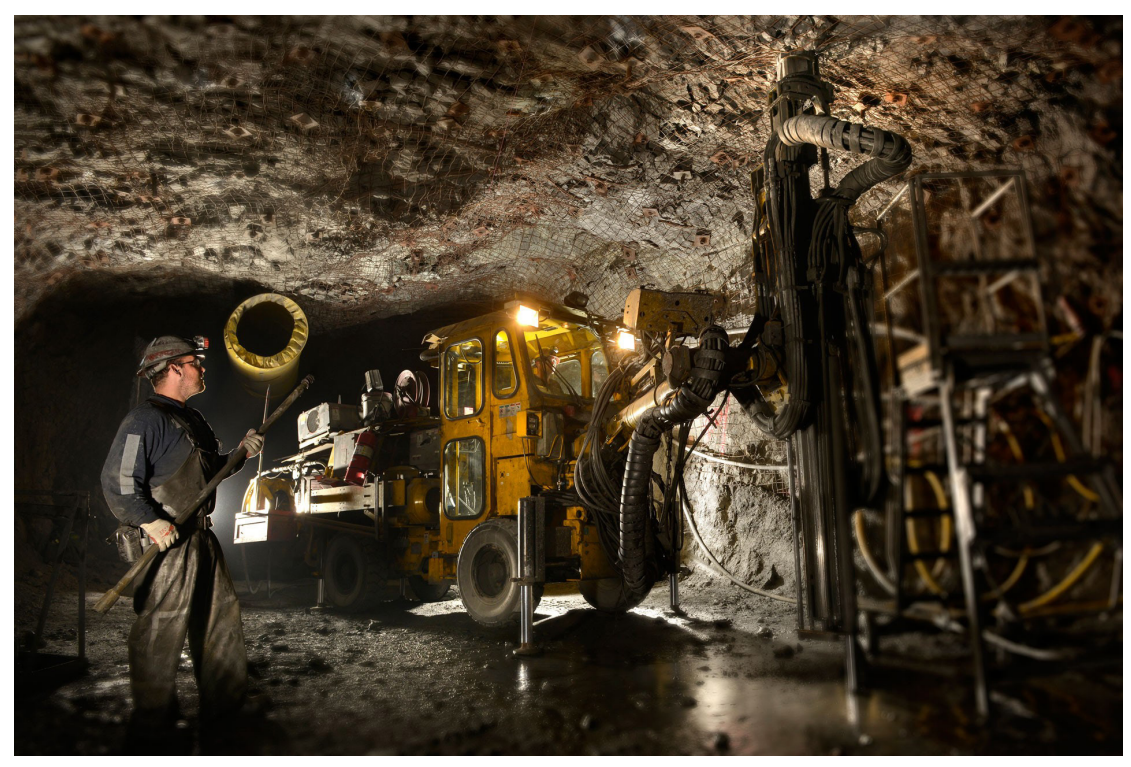




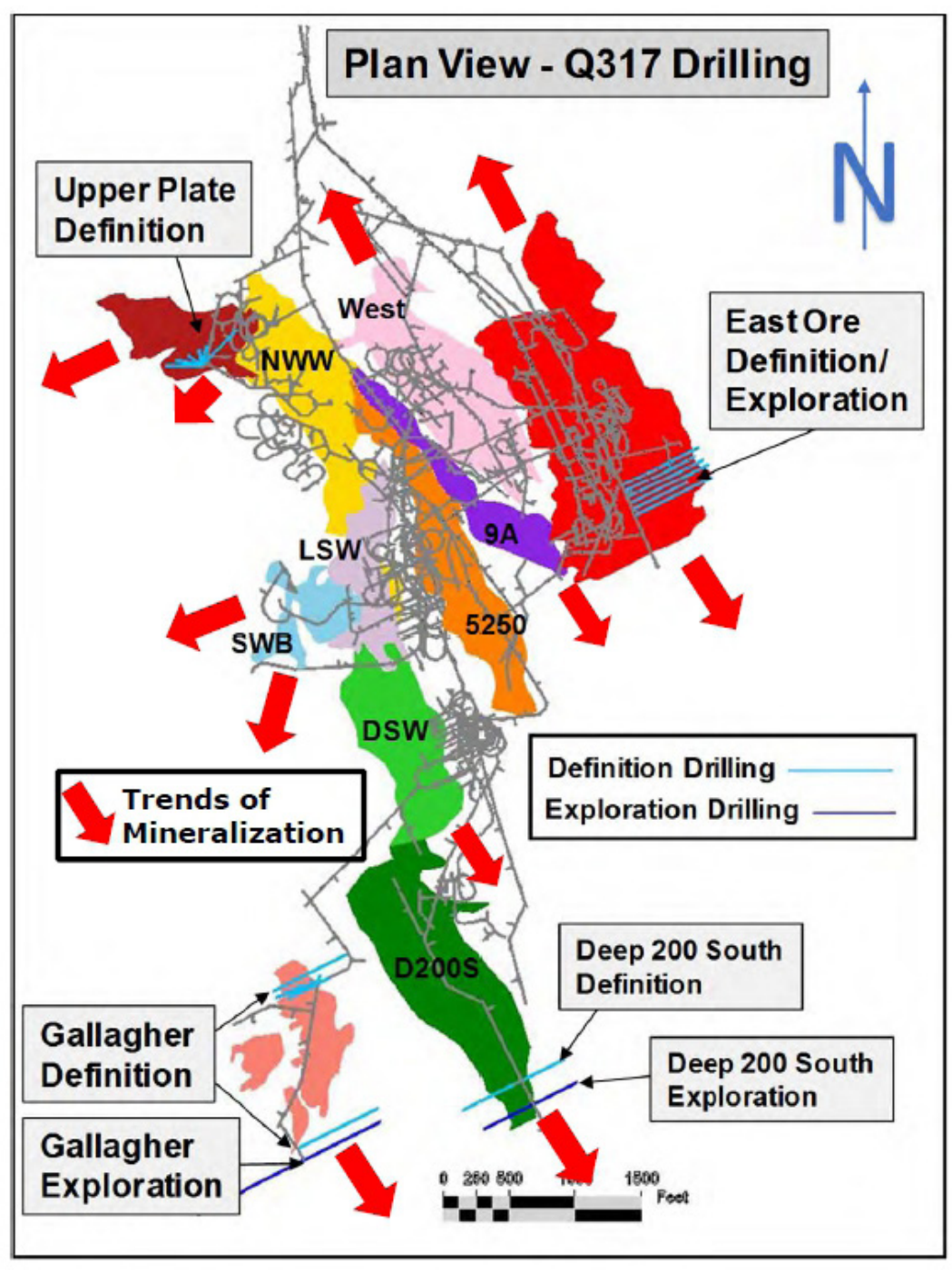

Figure 10. Greens Creek mine plan map showing location of ore bodies. Figure source: Hecla Mining Company; last accessed October 22, 2018; http://ir.hecla-mining.com/file/Index?KeyFile=390909600.
1,500 feet west of ore zones on the Klaus Shear at the mine.

In the third quarter, Hecla's drilling targeted the Deep 200 South, East Ore, Gallagher, and Upper Plate zones. Deep 200 South Zone exploration drilling extended 200 South Bench mineralization south of the current resource. East Ore Zone exploration drilling intercepted 75.1 ounces of silver per ton, 0.16 ounce of gold per ton, 5.32 percent zinc, and 2.67 percent lead over 9.5 feet in an area without previously identified resources, and another exploration drill hole intercepted 11.0 ounces of silver per ton, 0.13 ounce of gold per ton, 12.8 percent zinc, and 7.3 percent lead over 7.7 feet. Upper Plate Ore Zone assays further upgraded the existing resource and included 75.2 ounces of silver per ton, 0.09 ounce of gold per ton, 6 percent zinc, and 3 percent lead over 5.4 feet. This Upper Plate mineralization is close to underground mine infrastructure and only 300 feet below the mine portal. Gallagher Zone drilling identified new mineralization between current resources north of previous mining in the zone and down to the upper limb of the NWW; recent assay results include 47.2 ounces of silver per ton, 0.22 ounce of gold per ton, 4.3 percent zinc, and 2.0 percent lead over 7.9 feet. Surface drilling at Greens Creek commenced in late June at the Gallagher target, and the surface program is planned for over 21,000 feet of drilling to evaluate the Gallagher, East Ore, and 5250 zone targets. Initial drilling intersected a mineralized zone up to 100 -feet thick with sheared veins and breccia locally containing strong base metal mineralization along the flat-lying Klaus Shear. These intersections are over and included 11.6 ounces of silver per ton, 0.09 ounce of gold per ton, 5.2 percent zinc, and 2.5 percent lead over 32.3 feet. Surface drilling was completed on targets in the Gallagher, East Ore, and 5250 zones. Drilling on the Gallagher Zone intersected mineralized sheared veins and breccia intervals of up to 100 feet thick containing higher-grade intervals of 1.5 to 4 feet wide that have up to 15 percent zinc and 4.0 ounces of silver the same Klaus Shear identified within the mine workings east of the Gallagher fault. The mineralized Klaus Shear now extends 1,500 feet west per ton. This mineralized structure appears to be 
of the mine and over 3,000 feet north to south. Drilling also intercepted the main mine horizon of the 5250 Zone more than 2,000 feet south of the known resource.

In the fourth quarter, Hecla's drilling targeted the East Ore, Deep 200 South, Gallagher, Deep Southwest, and West zones. East Ore Zone definition drilling yielded one intersection with 32.3 ounces of silver per ton, 0.18 ounce of gold per ton, 9.0 percent zinc, and 4.8 percent lead over 19.8 feet. Step-out drilling, including an intersection of 54.2 ounces of silver per ton, 0.43 ounce of gold per ton, 4.25 percent zinc, and 1.34 percent lead over 19.0 feet, suggests strong mineralization continues beyond the resource to the south and at depth. Aggressive drilling of the East Ore Zone is planned to continue well into 2018. Definition drilling of the southern portion of the Deep 200 South Zone, including 40.1 ounces of silver per ton, 0.03 ounce of gold per ton, 6.0 percent zinc, and 4.2 percent lead over 18.9 feet, upgraded it to an indicated resource. Exploration drilling extended 200 South Bench mineralization another 300 feet with an intersection of 23.6 ounces of silver per ton, 0.06 ounce of gold per ton, 2.5 percent zinc, and 1.3 percent lead over 19.5 feet. Definition drilling of Gallagher Zone defined mineralization further to the west and east beyond the current resource. One intersection included 25.3 ounces of silver per ton, 0.01 ounce of gold per ton, 0.7 percent zinc, and 0.3 percent lead over 9.4 feet.

\section{Kensington}

Coeur Alaska, Inc.'s 2017 exploration expenditures totaled $\$ 8.6$ million at their Kensington mine north-northwest of Juneau. Coeur's program consisted of 77,730 feet of diamond drilling. Exploration focused on testing new veins in the district as well as expansion of the high-grade Jualin deposit (figure 11). Coeur continued to receive positive results from Jualin, and they also conducted exploration in higher-grade areas of the Raven and Kensington Main deposits. Up to five core rigs were active throughout 2017, with four focused on definition and expansion of the Jualin veins and the fifth on Kensington Main and Raven veins.

Exploration of deeper portions of Kensington Main continued to indicate an expansion of the zone's resource. Prior to ramping up the drill program at Jualin, several resource infill holes were drilled in Kensington Main Zones 12 and 41 and Blocks $M$ and L (figure 12). Drilling highlights included 7.8 feet grading 0.62 ounce of gold per ton and 2.3 feet grading 1.66 ounces of gold per ton from Block M. Coeur subsequently added new drill stations and resumed drilling in the adjacent Block L.

At Jualin, two underground drill rigs focused on upgrading existing resources and two others drilled Jualin from the surface. While the majority of holes are still pending assay results from the 2017 exploration program, highlights from 2016 include 4.5 feet grading 4.48 ounces of gold per ton and 4.5 feet grading 6.68 ounces of gold per ton (figure 13). The two underground rigs focused on infill drilling and conversion of inferred resource of Jualin Vein \#4. Portions of Jualin Vein \#4 are believed to continue at depth and to the northeast based on current drill results. These programs have since been completed and a reserve estimate at Jualin is expected to be included in the updated Kensington technical report anticipated in 2018. The two rigs drilling from surface focused on expansion of the Jualin resource. Initial planned holes were designed to test for extensions of Vein \#4, with a secondary priority of testing extensions of Veins \#2 and \#3 above Vein \#4. Drill results from Veins $\# 2$ and \#3 have demonstrated additional resource potential. Several holes were deepened to test the deepest-known structure, Vein \#5. Preliminary results suggest grades and thicknesses of mineralization similar to those of Vein \#4. Coeur also resumed drilling on the nearby Raven vein, where high-grade narrow-vein mining continues to augment Kensington's overall production. One drilling highlight included 5.0 feet grading 3.23 ounces of gold per ton. 


\section{Palmer}

At the Palmer volcanogenic massive sulfide (VMS), advanced-exploration-stage project near Haines, Constantine Metal Resources Ltd. (operator; 51 percent interest) and Dowa Metals \& Mining Alaska Ltd. (49 percent interest) have delineated an inferred resource of 9.0 million tons at 1.41 percent copper, 5.25 percent zinc, 0.925 ounce of silver per ton, and 0.0093 ounce of gold per ton for the South Wall deposit (appendix D). The Palmer property occurs within the same belt of rocks that host Greens Creek mine, one of the world's richest VMS deposits. In January 2017, Dowa Metals \& Mining Alaska Ltd. completed its $\$ 22$ million earn-in to Constantine Metal Resources Ltd.'s Palmer project and exercised its option to participate as a partner; a joint venture was formed. Dowa Metals \& Mining Alaska Ltd. is a subsidiary of Dowa Metals and Mining Co., Ltd., an integrated metals company that operates Japan's largest zinc smelter.

With a budget of $\$ 7.0$ million, in June 2017 Constantine commenced a 2-rig drilling program, totaling 35,164 feet, which included 10 holes for 10,567.6 feet at South Wall drilled for expansion and further definition of the resource, 13 holes for 16,381.2 feet at the Nunatak AG Zone, 3 holes for 3,300.5 feet at the Cap prospect, and 6 geotechnical holes for 4,918.0 feet. Most of Constantine's 2017 drilling budget was dedicated to discovery of new mineral deposits on their 108,000-acre land package. Priority exploration targets included the Nunatak AG Zone, Cap, HG, and JAG prospects that collectively define a several-mile-long, stratigraphically linked corridor of mineralization parallel to the South Wall-RW Zone trend. Constantine also conducted property-wide airborne geophysical surveying to assist with drill targeting, geological mapping, and prospecting. Other work included continued road construction, and engineering and environmental studies.

In July 2017, Constantine reported a highgrade, precious-metal discovery in the first-ever drill hole to test the Nunatak AG Zone prospect. DDH CMR17-89 intersected 30.2 feet of massive barite and sulfide grading 9.1 ounces of silver per ton and 0.026 ounce of gold per ton. The intersection is approximately 164 feet down-dip of a surface showing where a continuous chip sample returned 3.70 ounce of silver per ton over 15.4 feet. As Nunatak AG Zone drilling progressed, Constantine recognized that mineralization consists of stacked strata-bound zones across a thick interval of stratigraphy, with strong metal zonation between holes, including a high-grade silvergold-barite-rich upper zone and a zinc-rich lower zone. Mineralization styles include massive and semi-massive sulfide and barite, feeder-style stringers, and replacement ore. Most of the Nunatak AG Zone occurs on the steep, relatively planar limb, of a large-scale fold structure. The sheet-like aspect of mineralization along this limb permits predictive targeting toward neighboring prospect areas (along trend to the northwest at Waterfall and CAP

Figure 11. Map of Kensington, Raven, and Jualin deposits. Figure source: Coeur Alaska, Inc.; last accessed October 22, 2018; http://investors.coeur.com/ investors/news-and-media/news/. 
Figure 12. Northwest section view of Kensington Main ore bodies. Figure source: Coeur Alaska, Inc.; last accessed October 22,

2018; http://investors. coeur.com/investors/newsand-media/news/.

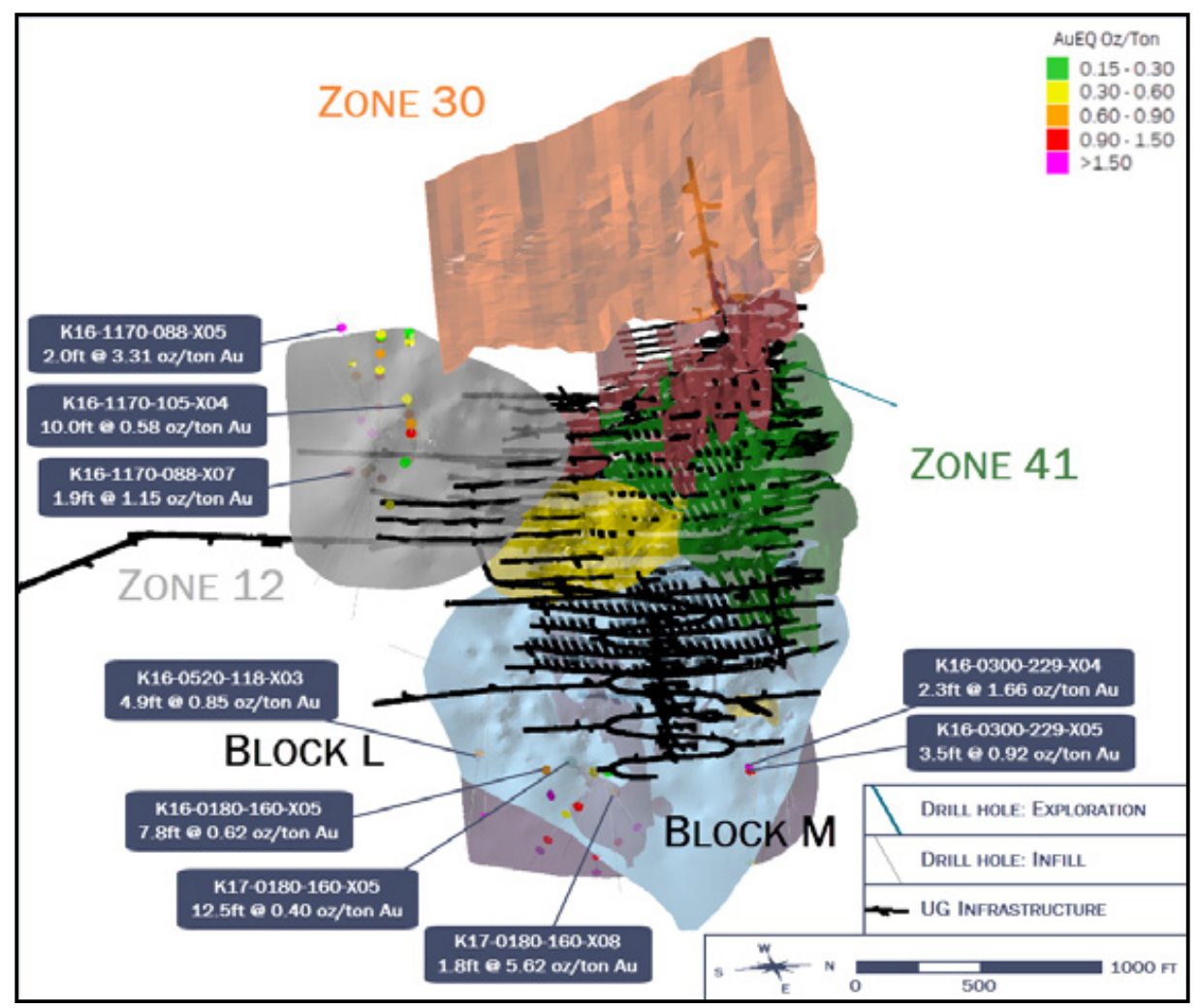

Figure 13. Northwest section view of Jualin ore bodies. Figure source: Coeur Alaska, Inc.; last accessed October 22, 2018; http://investors. coeur.com/investors/newsand-media/news/.

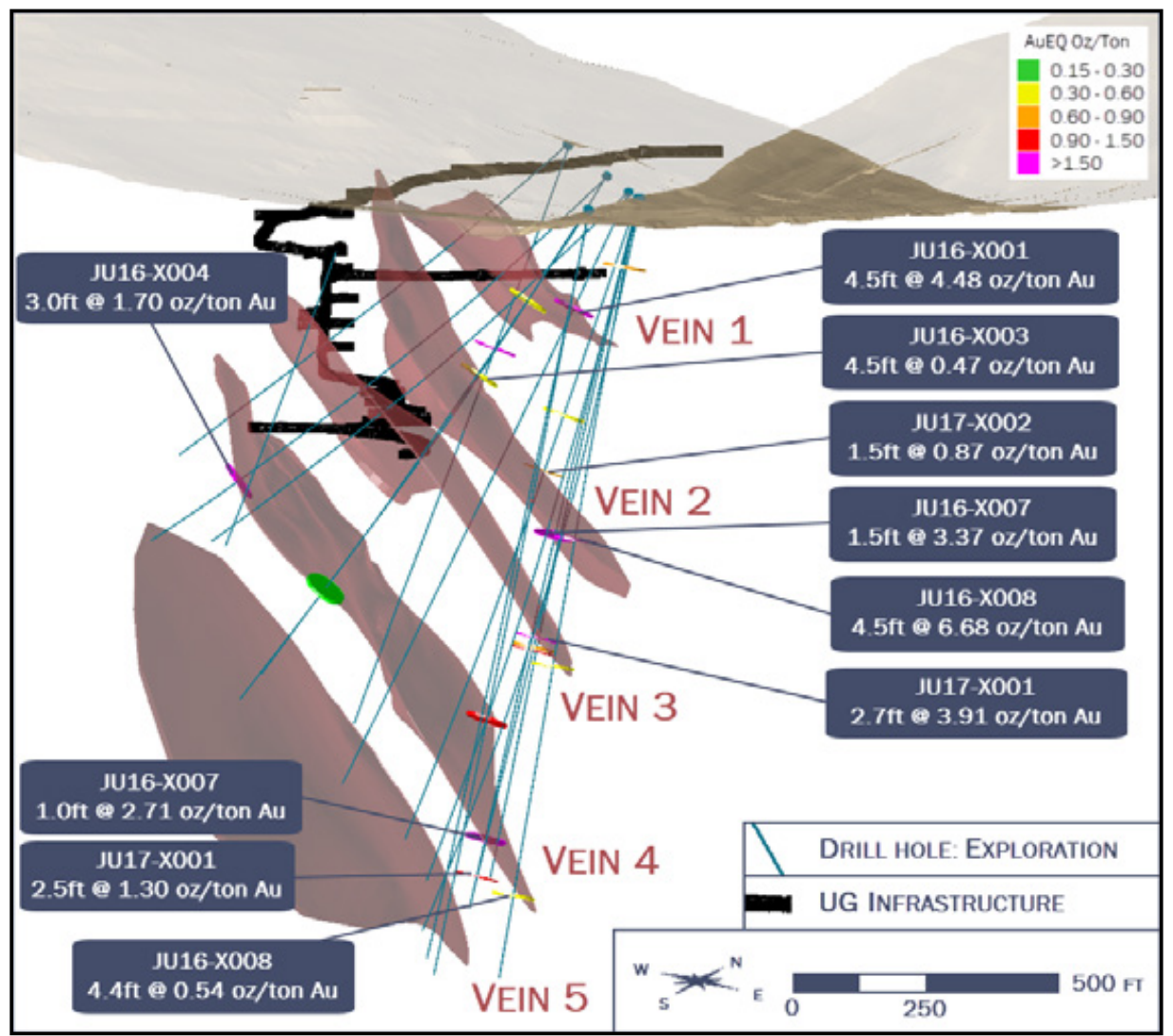


and southeast at JAG) and at depth below present drilling.

The Nunatak AG Zone has a drill-defined strike length of $738 \mathrm{feet}$, a vertical-dip length of 900 feet, and all sides are open to expansion as of November 2017. Significant mineralization was intersected in 11 of 13 drill holes, with most holes reporting multiple intersections. Drilling highlights for the Zinc Zone include 100.1 feet grading 7.3 percent zinc, 0.2 percent lead, 0.1 percent copper, 0.175 ounce of silver per ton, and 0.029 ounce of gold per ton. Highlights for the Silver Zone include 394.0 feet grading 0.90 ounce of silver per ton and 0.029 ounce of gold per ton. Additional highlights include: DDH CMR17-92 intersected 58.4 feet grading 11.7 percent zinc, 0.2 percent copper, 0.184 ounce of silver per ton, and 0.006 ounce of gold per ton, and 22.0 feet grading 5.7 percent zinc, 2.2 percent lead, 0.875 ounce of silver per ton, and 0.006 ounce of gold per ton; DDH CMR17-94 intersected 80.7 feet grading 7.58 ounces of silver per ton, 0.015 ounce of gold per ton, 1.4 percent zinc, and 0.5 percent lead; and DDH CMR17-96 intersected 66.9 feet grading 9.9 percent zinc, 0.2 percent copper, 0.420 ounce of silver per ton, and 0.029 ounce of gold per ton.

Constantine also conducted resource-expansion and upgrade drilling of the existing South Wall-RW Zone resource (appendix D); mineralization is both laterally and vertically zoned, with conductive pyrite-chalcopyrite-dominant massive sulfide and copper-rich feeder-style mineralization located in the core of sulfide lenses, flanked by volumetrically more abundant, weak to non-conductive barite-sphalerite-dominant mineralization (photo 19). The 2017 drilling expanding the mineralized zones, added tons, and increased confidence in the resource model, and currently the resource is open in multiple directions. The highlight was DDH CMR17-82, which intersected 149 feet grading 2.5 percent copper, 7.4 percent zinc, 1.14 ounces of silver per ton, and 0.009 ounce of gold per ton in an area poorly tested by previous drilling. Three holes were completed in a fan along the western edge of South Wall Zone; they were drilled in a gap between two historical holes, which had partial intercepts and passed immediately above and below the mineralized zone. The holes intersected a previously unrecognized zone of thick massive sulfide within the deposit area and also indicate potential for expansion to the west. Four additional drill holes from the South Wall Zone, in step-outs to the initial fan of holes, also included wide intersections of high-grade mineralization. Highlights include 68.6 feet grading 8.4 percent zinc, 0.1 percent copper, 1.17 ounces of silver per ton, and 0.006 ounce of gold per ton; and 47.6 feet grading 7.5 percent zinc, 1.9 percent copper, 1.93 ounces of silver per ton, and 0.012 ounce of gold per ton.

\section{Bokan Mountain}

Ucore Rare Metals, Inc. continued to analyze metallurgical processes and conduct geologic work on their Bokan Mountain rare-earth-element (REE) property in Southeast Alaska. In March 2017, Ucore entered into an option-topurchase agreement with IBC Advanced Technologies, Inc. and its shareholders, whereby Ucore has an option to purchase the outstanding shares of IBC. IBC is a world leader in molecular recognition technology for the mining industry, utilizing green chemistry to achieve highly selective separations of metal ions in complex matrices with their existing SuperLig extraction process. In 2016 SuperLig advanced nanotechnology was applied to Bokan Mountain rare-earth-bearing ore material and excellent metal-separation results were demonstrated by IBC.

In May 2017, Ucore was engaged in the detailed engineering and planning of a strategic metals complex (SMC) REE-separation facility with IBC. The SMC will utilize SuperLig Molecular Recognition Technology for the separation of REE, capitalizing on advanced pilot phase testing of the SuperLig-One pilot platform. The SMC is being designed and engineered as a modular facility, capable of accepting feedstock from varying supply sources and a range of high quality concentrates. Ucore is working on a comprehensive design-and-build schedule for the SMC facility, including an economic analysis of supply 


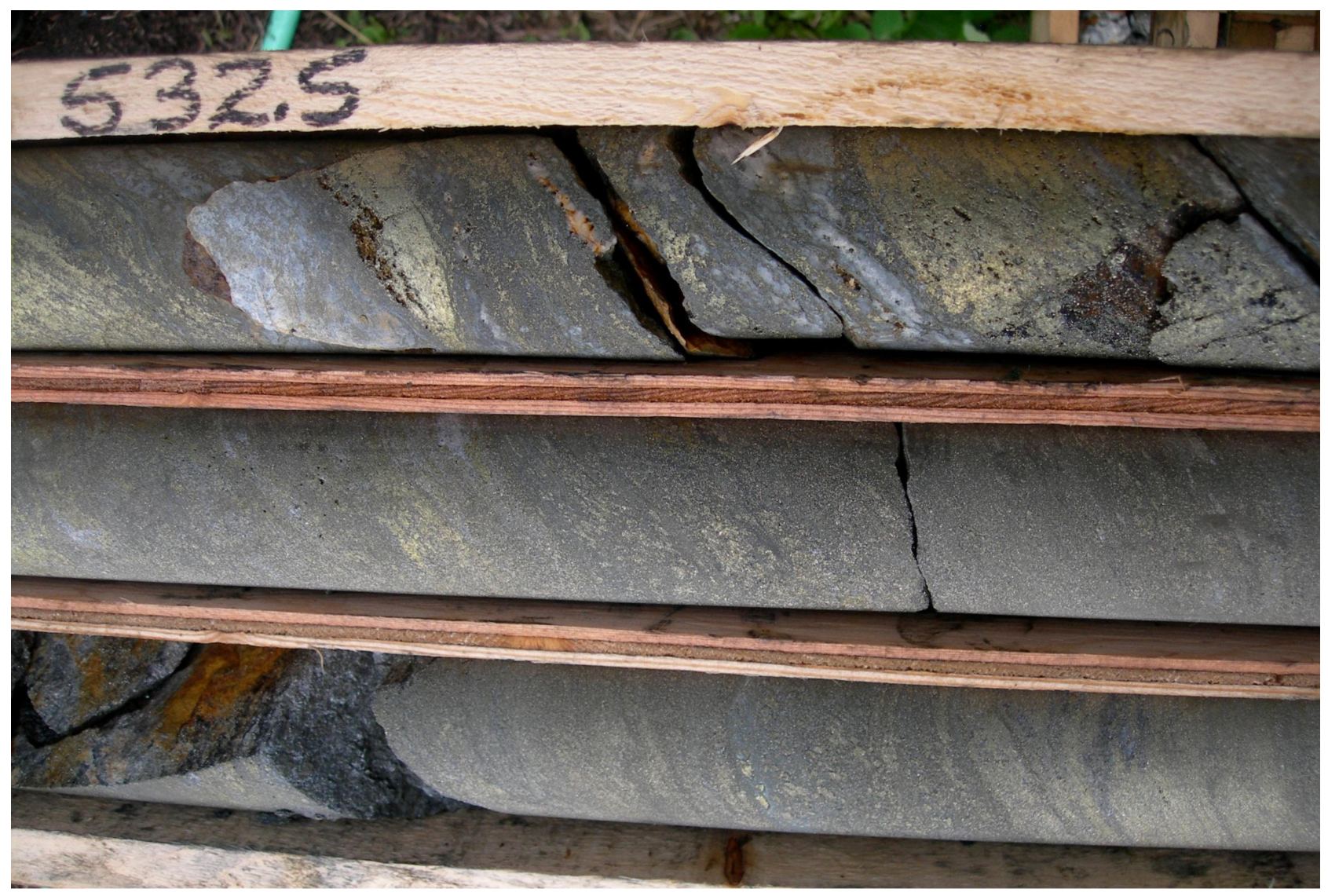

Photo 19. 2017 drilling in the Palmer project's South Wall Zone intersected high-grade mineralization such as this sulfide-rich core. Constantine Metal Resources Ltd.'s Palmer project is located near Haines, Alaska. Photo from: Constantine Metal Resources Ltd.; last accessed September 28, 2018; http://constantinemetals.com/ resources/ projects/palmer 20120221/sidebar/3.jpg.

sources. Alaska is one of three competing jurisdictions being evaluated for the location of the SMC, which is contingent upon incentives and logistical considerations. To help attract the SMC to Alaska, in March 31, 2014, the Alaska State Legislature authorized the investment of up to $\$ 145$ million in the Bokan project at the discretion of the Alaska Industrial Development and Export Authority.

In 2017 multiple bills were introduced in the U.S. Legislature to address the nation's needs for critical minerals security. In May 2017, the Consolidated Appropriations Act, 2017 was signed into law; Ucore stated it includes a significant authorization of funds for the processing and acquisition of strategic metals from tailings on U.S. soil, and directly addresses the Bokan project area in southeast Alaska, including \$5.5 million for the remediation of historical uranium mine waste from the nearby Ross-Adams mine site. In December 2017, President Trump signed the National Defense Authorization Act into law; it includes authorization for $\$ 5$ million in funding for the development of strategic materials technologies at the Army Research Laboratory. The funds have been set aside for the "development of improved manufacturing technology for separation, extraction, smelter, sintering, leaching, processing, beneficiation, or production of specialty metals," such as rare earth elements, which could benefit Ucore.

\section{Herbert Gold}

Grande Portage Resources Ltd. conducted a diamond drilling and surface exploration program in 2017 at its Herbert Gold project, an orogenic/ 
mesothermal gold-vein system near Juneau, with indicated and inferred resources totaling 961,970 tons grading 0.203 ounce of gold per ton for 195,225 ounces of gold, based on a 0.058 ounce of gold per ton cut-off grade and 127 diamond drill holes (appendix D). From northwest to southeast, currently recognized vein structures include the North Vein, Goat Creek Vein, Main Vein, Deep Trench Vein, and Floyd Vein. Goat Vein drill holes establish a strike length of over 1,150 feet; however, when combined with a 2017 discovery of new outcrops along the vein's eastward projection, a total of at least 2,000 feet of strike length is now indicated. Numerous combined representative grab samples collected over a 4-foot width of the exposed Goat Vein graded 6.74 ounces of gold per ton and 1.45 ounces of silver per ton.

Grande Portage completed their 2017 drill program in October, which included 12 holes from 4 pads totaling 12,139 feet; drilling was outside the existing resource. Grande Portage's drill program targeted the Main, Deep Trench, and Goat veins, and tested targets significantly deeper and further east than in prior years. Every hole hit its intended primary vein target(s) and many holes also encountered subsidiary quartz veins of substantial size, with disseminated arsenopyrite, pyrite, galena, sphalerite, and visible gold (photo 20). Split core samples taken from the centers of the veins were analyzed using the metallic screening process to capture coarse gold.

To date, the mineralized structures of the Deep Trench, Main, and Goat vein systems are open in all directions and at depth. Additionally, drilling to date has shown that the Deep Trench, Main, and Goat structures are in general very predictable and will almost always have values above 0.058 ounce of gold per ton (the lower minable resource cut-off grade) but will locally develop extremely high-grade regions of significant thickness.

Drilling highlights (including hanging wall and footwall veins for each vein system) for the Goat Vein system include: DDH 17K-1 intersected 2.8 feet grading 0.307 ounce of gold per ton; DDH $17 \mathrm{~K}-2$ intersected 3.8 feet grading 0.143 ounce of gold per ton; DDH $17 \mathrm{~K}-4$ intersected 10.3 feet grading 0.0458 ounce of gold per ton; DDH 17L-1 intersected 1.5 feet grading 0.767 ounce of gold per ton; DDH 17L-2 intersected 8.7 feet grading 0.815 ounce of gold per ton; DDH 17L-3 intersected 6.4 feet grading 0.219 ounce of gold per ton; and DDH $17 \mathrm{~L}-4$ intersected 20.7 feet grading 0.213 ounce of gold per ton. Drilling highlights for the Main Vein system include: DDH 17L-3 intersected 7.2 feet grading 0.149 ounce of gold per ton; $\mathrm{DDH}$ 17U-1 intersected 10.4 feet grading 0.083 ounce of gold per ton; and DDH 17Y-1 intersected 6.2 feet grading 0.306 ounce of gold per ton. Drilling highlights for the Deep Trench system include: DDH 17U-1 intersected 2.9 feet grading 0.0650 ounce of gold per ton; DDH 17Y-1 intersected 11.2 feet grading 0.0648 ounce of gold per ton; and DDH 17Y-2 intersected 9.2 feet grading 0.167 ounce of gold per ton.

\section{Zarembo Island}

The Zarembo Island property, 15 miles west of Wrangell, contains the historical Frenchie prospect, a volcanogenic massive sulfide-type prospect with geological similarities to the Greens Creek mine, as well as other lead-zinc-silvergold anomalies. The basal section of the sulfide zone at the Frenchie prospect contains five feet of massive pyrite (sulfides greater than 75 percent), and an eight-foot-thick section of semi-massive sulfide grading up to 4.8 percent zinc, 1 percent lead, and 0.058 ounce of gold per ton. West of the main exposure at Frenchie, a 3-foot-thick section of altered shale/argillite or tuff near the base of the sulfide zone grades 0.32 ounce of gold per ton and overlies a distinctive muscovite phyllite. The entire package of mineralized rock consists of 16.5 feet grading 0.127 ounce of gold per ton.

The sulfide-bearing section at Frenchie is highly conductive and magnetic, and is outlined by a helicopter aeromagnetic and electromagnetic survey conducted by DGGS and the BLM in 1996. In 2017 Zarembo Minerals Co. LLC contracted for reprocessing and a three-dimensional 


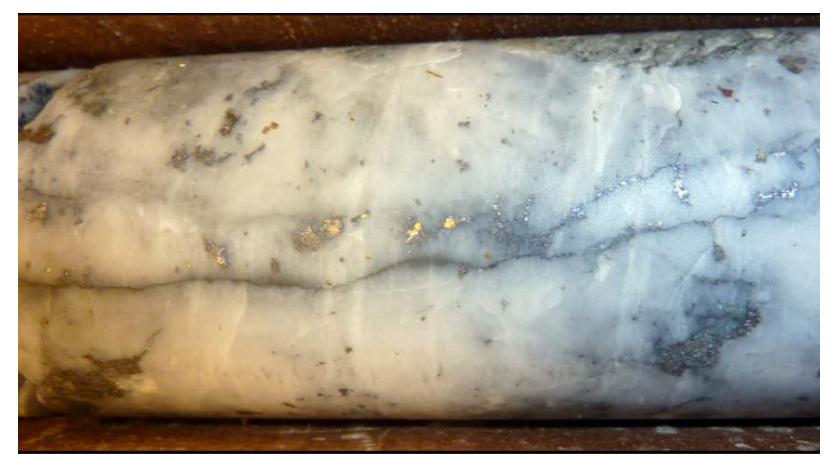

Photo 20. Grande Portage Resources Ltd.'s drilling encountered visible gold and disseminated arsenopyrite, pyrite, galena, and sphalerite in the Main, Deep Trench, and Goat veins at the Herbert Gold project near Juneau. Photo from: Grande Portage Resources Ltd., October 2017, Corporate presentation; last accessed November 2, 2017; http:// www.grandeportage.com.

inversion study of these electromagnetic and magnetic surveys. Modeling of the inversion data suggests the conductive and magnetic zones plunge to the southeast and are present in the subsurface. Soil geochemistry along the same trend suggests that mineralization is present. The main conductive zone containing Frenchie is at least 2.5 miles long. Zarembo Minerals conducted field investigations in 2017 to check the new inversion models.

\section{ALASKA PENINSULA REGION}

\section{Unga}

Redstar Gold Corp. explored their Unga project, which includes the Shumagin, Apollo, Centennial, Orange Mountain, Zachary Bay, Amethyst, and Aquila epithermal gold-silver prospects; this program utilized ground-based geophysical surveys, drilling, geologic mapping, and prospecting. In spring 2017, Redstar completed a 5.4-line-mile, ground-based Induced polarization-resistivity (IP) survey and a 9.6-line-mile magnetic survey at Shumagin Gold Zone to test the potential southwest extension of the Shumagin system and assist in defining 2017 drill targets (figure 14). The survey grid consisted of 21 northwest-oriented lines spaced 165 to 330 feet apart oriented perpendicular to the Shumagin Fault and high-grade breccia bodies, and ranged from
1,800 feet to 3,100 feet long. The geophysical data successfully traced the Shumagin Fault for at least 2,000 feet southwest from the most-southwest drill hole, and in addition, discovered a second parallel structure approximately 0.25 mile north of the Shumagin Gold Zone.

In May and June 2017, Redstar drilled geophysical anomalies on 330-foot centers along strike southwest of the known Shumagin Gold Zone to trace quartz-adularia-carbonate breccias along strike of the Shumagin Fault and the footwall splay, as well as to complete additional infill drilling to further confirm continuity of mineralization. Concurrent with drilling, detailed prospecting, mapping, surface rock sampling, and soil-sample grids were conducted over structures within northern footwall anomalies. In August 2017, Redstar announced its spring program results, including 12 drill holes totaling 7,506 feet of HQ and NQ core. Four holes (17SH026 to 16SH029) were designed to obtain accurate strike and dip measurements of the breccia system prior to drilling additional step out holes to the southwest. Drilling intersected the targeted Shumagin-style breccia structure in 10 out of 12 holes. Highlights include: a visible gold-bearing, quartzadularia-carbonate stockwork encountered in DDH $17 \mathrm{SH} 032$ returned 3.3 feet at 0.061 ounce of gold per ton and 0.788 ounce of silver per ton; infill hole DDH 17SH033 intersected 2.3 feet at 0.166 ounce of gold per ton and 0.875 ounce of silver per ton; and infill hole DDH $17 \mathrm{SH} 034$ intersected 7.2 feet at 0.289 ounce of gold per ton and 0.855 ounce of silver per ton. Step-out drill holes 17SH030 and 17SH031 targeted shallow projections approximately 250 feet below the surface along strike of the breccia system, whereas drill holes 17SH032, 17SH035, 17SH036, and 17SH037 were drilled along 330-foot grid lines for approximately 1,640 feet of strike with a goal to trace the breccia system at approximately 500 feet below the surface.

Redstar's fall-program included drilling 13 holes totaling 8,665 feet, and excavation and sampling of prospecting pits near areas of anomalous 
gold and pathfinder elements from previously gridded soil samples surrounding the Saddle Creek and High-Grade Scarp anomalies. Eleven of the drill holes, totaling 7,897 feet, were drilled to test target areas surrounding Bunker Hill and along strike to the East Zone, all northeast of prior drilling within the Shumagin Gold Zone. Each of the 11 holes intercepted gold and silver mineralization, which is concentrated within the colloform-textured, carbonate-green clay breccia. Continuity of mineralization between the Main Breccia and Bunker Hill was indicated by drill hole 17SH042, which intercepted an 27.2-foot interval of mineralization with the highest interval returning 0.126 ounce of gold per ton and 0.0621 ounce of silver per ton over 2.3 feet. Drill Hole $17 \mathrm{SH} 047$ intercepted a 53.5-foot interval of mineralization with the highest value returning
0.106 ounce of gold per ton and 0.298 ounce of silver per ton over 1.6 feet. The Shumagin Gold Zone now has shown continuity for approximately 5,740 feet, an expansion of 84 percent over 2016.

Additionally, two holes totaling 767.4 feet were drilled in the Rising Sun Gold Zone near the historical Apollo gold mine in the ApolloSitka Gold Trend, which is located approximately 1.9 miles to the south and parallel to the Shumagin Gold Zone. Rising Sun is a splay off of the main Apollo structure approximately 1,000 feet east of the Apollo open stope and consists of an 82-foot-wide outcrop with multi-generational veins, vein breccias, and stockwork. This is the first drill test outside of the Shumagin Gold Zone on Unga Island. Both drill holes encountered shallow intercepts of quartz-adularia-carbonate

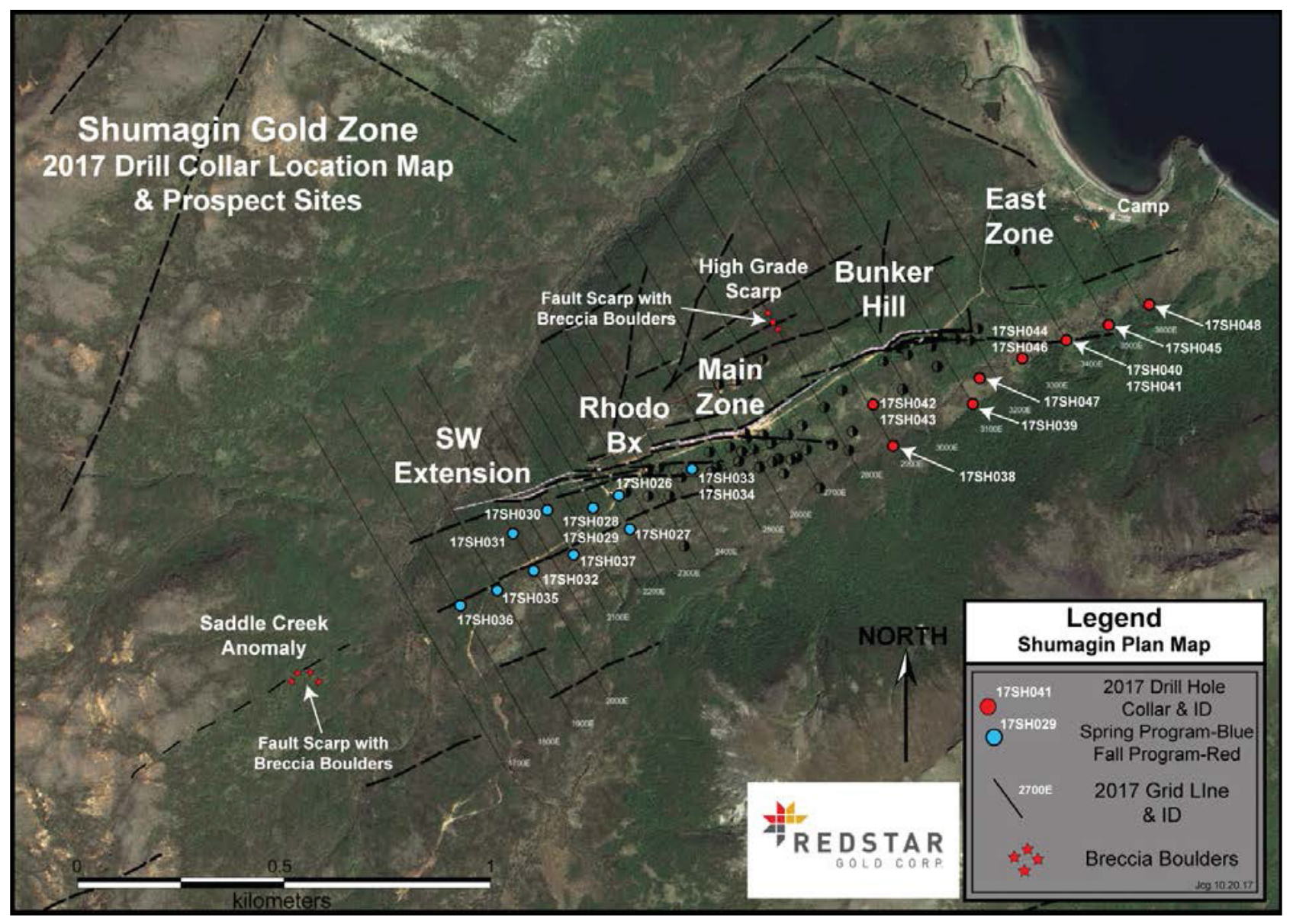

Figure 14. Drill hole location and prospect map for Redstar Gold Corporation's Shumagin Gold Zone. Figure source: Redstar Gold Corp.; last accessed October 22, 2018; https://www.redstargold.com/hews/2017/redstar-golds-2017fall-drill-program-successfully-intersects-shumagin-style-breccia-vein-structures-in-main-breccia-bunker/. 
breccias and stockwork. Narrow, 5 to 20 -footwide crustifrom to cockade textured breccias haloed by narrow quartz-sericite-pyrite alteration and strong silicification cut moderately propylitically altered basalt, andesite, and hyaloclastite flows. DDH 17RS01 intercepted 0.002 ounce of gold per ton and 0.505 ounce of silver per ton over 3.3 feet. Deeper drilling along DDH 17RS02 returned 0.0084 ounce of gold per ton and 0.527 ounce of silver per ton over 4.6 feet.

\section{Pyramid}

The Pyramid project is an early stage porphyry copper-molybdenum-gold exploration project, located on Aleut Native Corporation land on the Alaska Peninsula, which is being explored by CopperBank Resources Corp. (photo 21). The Pyramid deposit has an initial NI 43-101-compliant inferred resource of 191 million tons of 0.35 percent copper for 1.338 billion pounds of copper, 0.02 percent molybdenum for 74 million pounds of molybdenum, and 0.0026 ounce of gold per ton for 488,000 ounces of gold. The resource was calculated based on historical drilling of 24,560.4 feet in 30 holes drilled between 2010 and 2012 (appendix D). In March 2017, CopperBank contracted DOWL to develop initial concepts for potential port site locations, on-site power generating options, and a supporting road network for the Pyramid project.

CopperBank used two drill rigs to complete 13 holes of NQ-size core for a total of 12,106.3 feet from July 29 to September 3, 2017. The known 5,900 foot by 3,400 foot mineralization footprint is open in all directions and is divided into three zones: Main, North, and West. The 2017 drilling program was designed to validate the existing block model, to increase tonnage and examine higher grade portions of the deposit, to verify extensions of known mineralization outside the resource, and to take larger step-outs to test areas of surface-exposed mineralization and alteration. The 2017 drill data will be used to update Pyramid's resource estimate and to plan future drill programs.
Highlights of CopperBank's 2017 drilling include: DDH 17PY031 (western extension of North Zone) intercepted 0.235 percent copper over 19.7 feet as chalcocite disseminations associated with a weak potassic overprint; DDH 17 PY032 (Main Zone) had three significant near-surface intervals totaling more than 951.4 feet at grades higher than 0.33 percent copper; the best intercept was 659.5 feet grading 0.48 percent copper, 0.021 percent molybdenum, and 0.0029 ounce of gold per ton; DDH 17PY033 (Main Zone), drilled to a depth of 1,230.3 feet, intersected 984.3 feet of 0.53 percent copper, including 134.0 feet of 1.17 percent copper along the contact between hornfels and clay-altered quartz diorite porphyry and DDH 17PY034 (North Zone), drilled to a depth of 784.1 feet, intersected 764.0 feet of 0.19 percent copper. Hornfels intruded by numerous porphyry dikes hosts continuous copper mineralization with higher molybdenum grades than typically observed elsewhere in the deposit. DDH 17PY035 (Main Zone), drilled to a depth of 1,148.0 feet, contained significant chalcopyrite and chalcocite associated with the main quartz diorite porphyry intrusion and it intersected 449.5 feet of 0.45 percent copper and 374.0 feet of 0.37 percent copper; the two intervals are separated by a 85 -foot-wide fault zone of clay altered quartz diorite porphyry. DDH 17PY036 (North Zone), drilled to a depth of 823.0 feet, encountered hornfels intruded by porphyry dikes, which host disseminated chalcopyrite and chalcocite; it bottomed in magnetic quartz-biotite diorite. One interval returned 0.37 percent copper over 588.9 feet. DDH 17PY037 (Main Zone), located outside the historical resource envelope, was mineralized from 24.0 feet over its entire length; the 1,063-foot intercept grades 0.31 percent copper. DDH 17PY038 (North Zone) intercepted 164.0 feet of 0.31 percent copper near the top of the hole, with mainly hornfels intruded by a few porphyry dikes and disseminated chalcopyrite and chalcocite. DDH 17PY039 (between Main and West zones) clearly shows an affiliation to the West Zone and chalcopyrite and chalcocite appear to be associated with quartz-feldspar porphyry dikes. DDH 17PY040 (south of North Zone) tested 


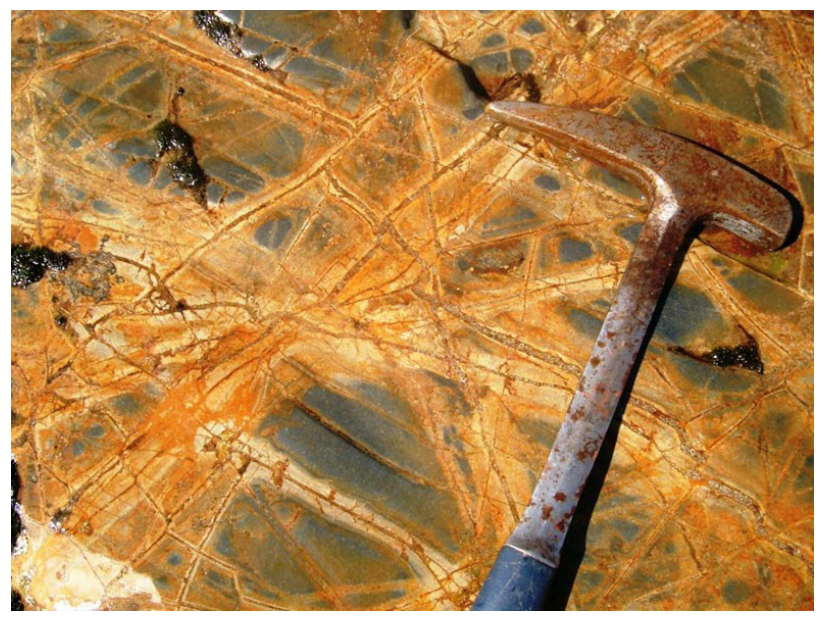

Photo 21. Copper-molybdenum-gold mineralization at CopperBank Resources Corp.'s Pyramid project on the Alaska Peninsula is hosted in stockwork veining and alteration of porphyritic intrusive rocks and hornfelsed sedimentary country rocks. Photo from: CopperBank Resources Corp.; last accessed October 1, 2018; http://copperbankcorp.com/ gallery/album-3/ Ig/pyramid-photo-gallery-07.jpg.

outcropping chalcocite and intersected quartz diorite porphyry, including a consistent interval of elevated copper starting at 23.0 feet depth with a weighted-average grade of 0.10 percent copper over 990.8 feet. Two samples from phenocryst-rich feldspar porphyry dikes yielded gold values of 0.0333 and 0.0659 ounce of gold per ton. DDH 17PY041 (West Zone) cut a series of feldspar porphyry dikes containing disseminated chalcopyrite, chalcocite, and chrysocolla; the hole bottomed in mineralization, with the last sample returning 1.26 percent copper. DDH 17PY042 (eastern extension of North Zone) and DDH 17PY043 (northern extension of West Zone) encountered weak copper mineralization.

In November CopperBank hired Auracle Geospatial Science Inc. to complete a remote-sensing radar study to assist in detecting major structures and hyperspectral survey to help determine the nature and distribution of alteration for both their Pyramid and San Diego Bay projects.

\section{San Diego Bay}

The San Diego Bay project, located 6.2 miles west of the Pyramid porphyry copper deposit on the Alaska Peninsula, is a joint-venture between CopperBank Resources Corp. and the Aleut Corporation, an Alaska Native corporation controlling the subsurface mineral rights. The San Diego Bay project covers a 15 -square-mile area with strong hydrothermal alteration and intrusive rocks. Porphyry alteration facies observed include potassic, advanced argillic, and phyllic zones.

In August CopperBank initiated a selective, reconnaissance prospecting and soil sampling program to test historical copper and gold anomalies, which reached 4.3-16 percent copper and several values over 0.0292 ounce of gold per ton in rock samples, as well as molybdenum, zinc, silver, and lead anomalies. They collected 37 rock grab samples and $173 \mathrm{C}$-horizon soil samples. Soil sampling was performed over San Diego Bay, Renshaw Point, and Balboa Bay. The Balboa area displays a multi-element soil anomaly in copper, gold, molybdenum, and silver spreading over 1.7 miles along a northeast trend and an apparent average width of 1,640 feet. This area encloses the auriferous Oh Boy Vein in its southwestern part, historically described as a 100-foot-wide quartz vein zone. The area sampled near the intrusion at Renshaw Point revealed a soil anomaly of nearly 1,300 feet in length returning silver values averaging more than 0.0292 ounce of silver per ton and local gold values over 0.0058 ounce of gold per ton along the intrusive contact. The tested area around the intrusion of San Diego Bay returned a single gold-anomalous sample $(0.0018$ ounce of gold per ton). Rock sampling, limited to the Balboa area, returned several samples with values of greater than 0.1 percent copper and greater than 0.0029 ounce of gold per ton, with a maximum of 0.019 ounce of gold per ton. One sample collected in a strongly silicified andesite, with up to 10 percent disseminated and blebby pyrite, yielded 1.37 percent zinc. Another sample collected in an intensely silicified zone returned 2.89 ounces of silver per ton and 0.0070 ounce of gold per ton. Strongly silicified andesite and volcaniclastic rocks cut by quartz veins bearing sulfides and hydrothermal breccia are the dominant lithologies. 


\section{DEVELOPMENT AND PRODUCTION}

\section{Market valuations of mining companies significantly improved in 2017.}

According to S\&P Global Market Intelligence, in 2017 a majority of the top 25 mining companies at least doubled in value. With greater optimism from higher metal prices and increased cash flow, companies spent more on development and exploration (table 9). For Alaska's six mines, that optimism was reflected in an increase of spending on exploration and development (total increase of $\$ 82.3$ million or 36 percent) at the expense of production (decrease of $\$ 94.3$ million or 9 percent) in 2017 over the previous year. In 2017 Alaska's purely development projects also allocated a portion of their funds to exploration.

Overall, reported development expenditures in 2017 were 38 percent more than in 2016, with ten projects and mines spending a total of approximately $\$ 299.5$ million. Projects that reported significant development expenditures are shown in figure 15; Red Dog, Fort Knox, Pogo, Kensington, and Greens Creek mines together spent more than $\$ 266.0$ million, 89 percent of the total. Precious-metals projects comprised 70 percent of the development expenditures in 2017, nine percent more than in 2016 (table 10). Precious metals have been the impetus behind annual development investment for more than 15 years.

Higher metals prices, aided by an improved global economy, weaker U.S. dollar, and stronger supply and demand fundamentals, helped increase total mining revenue in Alaska by seven percent to $\$ 2.7$ billion, despite decreased production in all commodities (tables 1 and 11).6,8 The mining revenue metric, which takes into account the actual value of commodities, was introduced for 2016 mining year reporting. It is largely based on confidential data. The estimated value of mineral production in Alaska, including theoretical first market values substituted for confidential data, increased almost 11 percent, from \$2.9 billion to $\$ 3.2$ billion (table 11$)$. For comparison,

Table 9. Average metal prices, 1996-2017.

\begin{tabular}{|c|c|c|c|c|c|}
\hline Year & $\begin{array}{l}\text { Gold } \\
\$ / o z\end{array}$ & $\begin{array}{r}\text { Silver } \\
\$ / o z\end{array}$ & $\begin{array}{c}\text { Copper } \\
\$ / \mathrm{lb}\end{array}$ & $\begin{array}{c}\text { Lead } \$ / \\
\text { lb }\end{array}$ & $\begin{array}{l}\text { Zinc } \\
\$ / / \mathbf{b}\end{array}$ \\
\hline 1996 & 387.60 & 5.19 & 1.03 & 0.37 & 0.49 \\
\hline 1997 & 330.76 & 4.91 & 1.03 & 0.28 & 0.59 \\
\hline 1998 & 293.88 & 5.53 & 0.75 & 0.24 & 0.46 \\
\hline 1999 & 278.70 & 5.20 & 0.71 & 0.23 & 0.49 \\
\hline 2000 & 279.10 & 4.96 & 0.82 & 0.21 & 0.51 \\
\hline 2001 & 271.04 & 4.37 & 0.71 & 0.22 & 0.40 \\
\hline 2002 & 310.06 & 4.61 & 0.41 & 0.21 & 0.35 \\
\hline 2003 & 363.38 & 4.88 & 0.81 & 0.23 & 0.38 \\
\hline 2004 & 409.72 & 6.67 & 1.29 & 0.40 & 0.47 \\
\hline 2005 & 444.74 & 7.32 & 1.61 & 0.43 & 0.63 \\
\hline 2006 & 603.46 & 11.55 & 3.02 & 0.58 & 1.47 \\
\hline 2007 & 695.39 & 13.38 & 3.24 & 1.17 & 1.47 \\
\hline 2008 & 871.96 & 14.99 & 3.12 & 0.94 & 0.84 \\
\hline $2009^{a}$ & 972.35 & 14.67 & 2.35 & 0.78 & 0.75 \\
\hline $2010^{\mathrm{a}}$ & $1,224.53$ & 20.19 & 3.42 & 0.97 & 0.98 \\
\hline $2011^{a}$ & $1,571.52$ & 35.12 & 3.99 & 1.09 & 0.99 \\
\hline $2012^{a}$ & $1,668.98$ & 31.15 & 3.61 & 0.93 & 0.88 \\
\hline $2013^{a, b}$ & $1,411.23$ & 23.79 & 3.32 & 0.97 & 0.87 \\
\hline $2014^{\mathrm{a}, \mathrm{b}}$ & $1,266.40$ & 19.78 & 3.11 & 0.95 & 0.98 \\
\hline $2015^{\mathrm{a}, \mathrm{b}}$ & $1,160.06$ & 15.68 & 2.50 & 0.81 & 0.88 \\
\hline $2016^{a, b}$ & $1,250.74$ & 17.14 & 2.21 & 0.85 & 0.95 \\
\hline $2017^{a, b}$ & $1,257.12$ & 17.04 & 2.80 & 1.02 & 1.26 \\
\hline
\end{tabular}

The figures in this table will change as data are reviewed and updated. a2009-2017 gold and silver prices from Kitco cumulative average London PM fix; 2009-2012 copper, lead, and zinc from British Columbia Ministry of Energy and Mines.

b2013-2017 copper, lead, and zinc prices from U.S. Geological Survey Mineral Commodity Summaries, based on London Metal Exchange (LME), and LME average daily settlement. 
gross mining income for tax purposes increased 33 percent, from $\$ 1.9$ billion in 2016 to $\$ 2.5$ billion in 2017 (table 4).

Zinc remains the State's leading mineral product, with a production value of $\$ 1.60$ billion in 2017 (a 28 percent increase from 2016), despite more than a decade of expenditures in Alaska leaning toward the exploration and development of precious metals (table 11). Zinc accounted for almost half of Alaska's production value (figure 16). The annual value of zinc production has

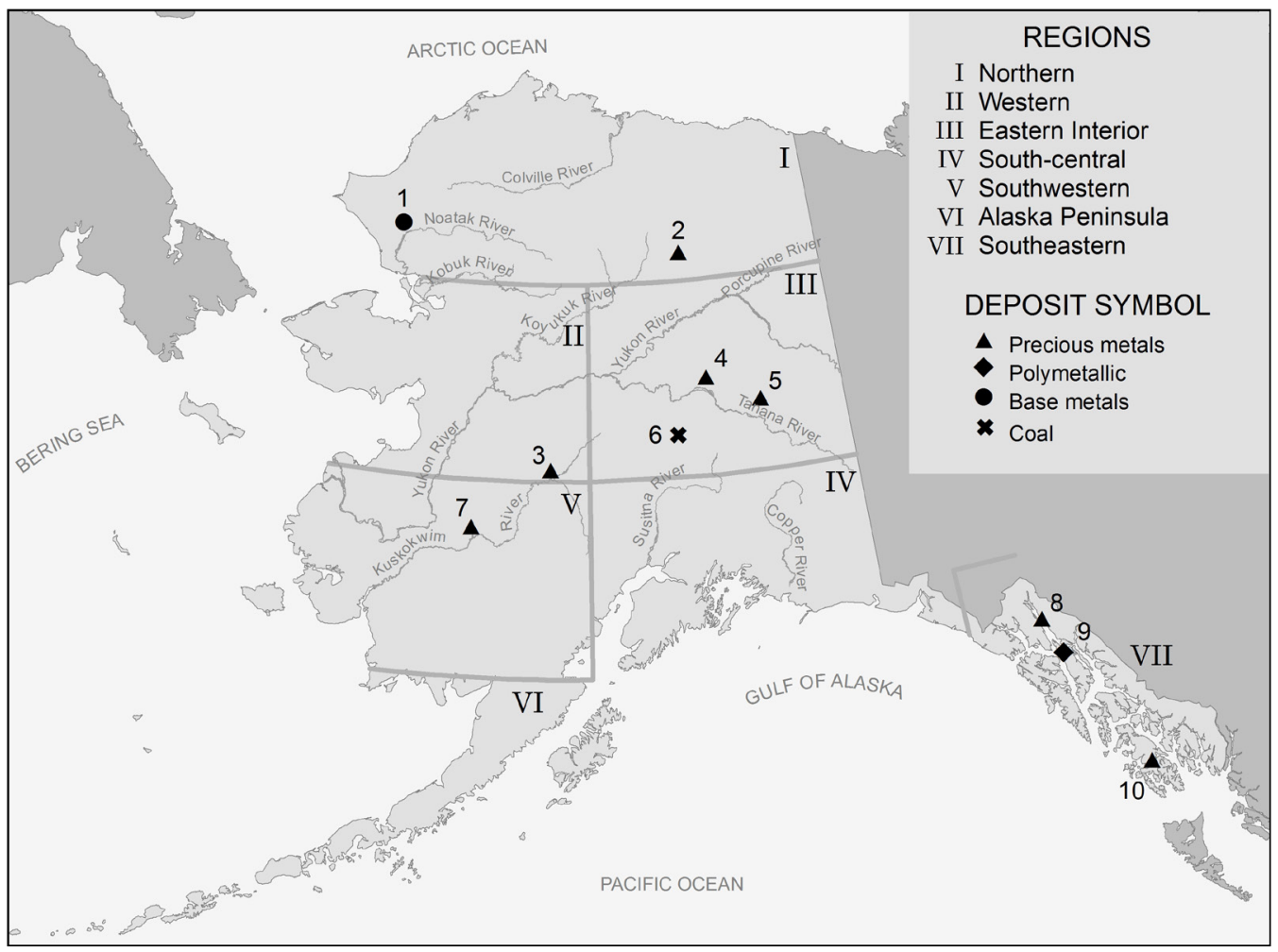

Figure 15. Selected development projects and mines in Alaska, 2017.

\section{Production \& Development}

\section{Northern Region}

1 Red Dog Mine-Teck Alaska Inc.

2. Chandalar placer mine-Goldrich NyacAu Placer LLC

\section{Western Region}

3. Nixon Fork-Mystery Creek Resources Inc.*

\section{Eastern Interior Region}

4. Fort Knox Mine-Fairbanks Gold Mining Inc.

5. Pogo-Sumitomo Metal Mining Pogo LLC

6. Usibelli Coal Mine-Usibelli Coal Mine Inc.

\section{South-central Region}

\section{Southwestern Region}

7. Donlin Gold project-Donlin Gold $\mathrm{LLC}^{*}$

\section{Alaska Peninsula Region}

\section{Southeastern Region}

8. Kensington-Coeur Alaska Inc.

9. Greens Creek Mine-Hecla Mining Company

10. Dawson Mine-Sundance Mining Group LLC*

* Development activity only 
Table 10. Reported mineral development expenditures in Alaska by commodity, 1982-2017.

\begin{tabular}{|c|c|c|c|c|c|c|c|}
\hline Year & Base Metals & Polymetallics $^{a}$ & $\begin{array}{c}\text { Precious } \\
\text { Metals }\end{array}$ & Gemstones $^{b}$ & $\begin{array}{c}\text { Industrial } \\
\text { Minerals }\end{array}$ & Coal and Peat & Total \\
\hline 1982 & $\$ 10,270,000$ & & $\$ 19,320,000$ & & $\$ \quad 4,251,000$ & $7,750,000$ & $\$ 41,591,000$ \\
\hline 1983 & $19,500,000$ & & $7,112,500$ & & $1,000,000$ & 250,000 & $27,862,500$ \\
\hline 1984 & $10,710,500$ & & $15,058,555$ & & 579,000 & $27,000,000$ & $53,348,055$ \\
\hline 1985 & $13,000,000$ & & $16,890,755$ & & $1,830,000$ & $2,400,000$ & $34,120,755$ \\
\hline $1986^{a}$ & $3,260,800$ & $8,000,000$ & $12,417,172$ & & 124,000 & 530,000 & $24,331,972$ \\
\hline 1987 & $38,080,000$ & $48,000,000$ & $13,640,848$ & & 188,000 & 342,000 & $100,250,848$ \\
\hline 1988 & $165,500,000$ & $69,000,000$ & $40,445,400$ & & -- & -- & $274,945,400$ \\
\hline 1989 & $118,200,000$ & 411,000 & $6,465,350$ & & $7,000,000$ & $2,196,000$ & $134,272,350$ \\
\hline 1990 & -- & $4,101,000$ & $7,136,500$ & & 30,000 & $3,079,000$ & $14,346,500$ \\
\hline 1991 & -- & $8,000,000$ & $14,994,350$ & & 262,000 & $2,318,000$ & $25,574,350$ \\
\hline 1992 & 80,000 & $4,300,000$ & $23,151,300$ & & 404,000 & $1,655,000$ & $29,590,300$ \\
\hline 1993 & -- & $10,731,136$ & $15,103,000$ & & 433,500 & $1,400,000$ & $27,667,636$ \\
\hline 1994 & $10,000,000$ & $5,000,000$ & $27,392,850$ & & 5,000 & $2,545,000$ & $44,942,850$ \\
\hline 1995 & $11,200,000$ & $9,590,000$ & $127,165,750$ & & 426,000 & 200,000 & $148,581,750$ \\
\hline 1996 & $60,000,000$ & $60,100,000$ & $273,042,000$ & & 495,000 & 400,000 & $394,037,000$ \\
\hline 1997 & $133,880,000$ & 7,300,000 & $26,299,000$ & & 500,000 & 410,000 & $168,389,000$ \\
\hline 1998 & $28,000,000$ & $5,600,000$ & $15,602,000$ & & $5,355,000$ & 850,000 & $55,407,000$ \\
\hline 1999 & $12,500,000$ & $2,500,000$ & $15,864,000$ & & 400,000 & $2,575,000$ & $33,839,000$ \\
\hline 2000 & $100,000,000$ & $16,400,000$ & $24,699,000$ & & 611,000 & -- & $141,710,000$ \\
\hline 2001 & $43,800,000$ & $3,300,000$ & $32,719,000$ & & 300,000 & $1,040,000$ & $81,159,000$ \\
\hline 2002 & -- & $5,700,000$ & $26,655,000$ & & 250,000 & $1,450,000$ & $34,055,000$ \\
\hline 2003 & -- & -- & $38,839,332$ & & 315,000 & -- & $39,154,332$ \\
\hline 2004 & $17,700,000$ & $6,215,000$ & $177,440,081$ & & $4,991,434$ & $2,760,000$ & $209,106,515$ \\
\hline 2005 & $28,000,000$ & $16,700,000$ & $301,011,469$ & & 856,500 & $1,350,000$ & $347,917,969$ \\
\hline 2006 & $31,200,000$ & $26,183,280$ & $420,759,203$ & & $1,566,000$ & $15,985,000$ & $495,693,483$ \\
\hline 2007 & $41,374,880$ & $30,766,902$ & $239,931,040$ & & $1,320,500$ & $5,385,000$ & $318,778,322$ \\
\hline 2008 & $45,000,000$ & $24,000,000$ & $319,702,594$ & & 205,113 & $7,260,000$ & $396,167,707$ \\
\hline $2009^{b}$ & $29,000,000$ & $17,500,000$ & $277,020,142$ & $\$ 225,250$ & 270,000 & $6,800,000$ & $330,815,392$ \\
\hline 2010 & $42,000,000$ & $16,300,000$ & $225,793,300$ & 200,000 & -- & $9,000,000$ & $293,293,300$ \\
\hline 2011 & $48,590,865$ & $41,657,000$ & $170,931,851$ & 250,000 & 902,480 & $9,560,000$ & $271,892,196$ \\
\hline 2012 & $35,234,500$ & $62,184,000$ & $235,642,406$ & -- & $5,290,870$ & $4,021,544$ & $342,373,320$ \\
\hline 2013 & W & $57,119,121$ & $258,130,353$ & 295,000 & $1,831,369$ & W & $358,775,844$ \\
\hline 2014 & W & W & $199,909,824$ & 700,000 & 756,495 & -- & $281,735,787$ \\
\hline $2015^{c}$ & W & W & $188,226,940$ & -- & -- & - - & $309,938,884$ \\
\hline 2016 & W & $47,046,279$ & $133,243,900$ & -- & -- & W & $217,376,728$ \\
\hline 2017 & W & $35,254,986$ & $209,082,444$ & -- & -- & W & $299,502,316$ \\
\hline Total & $\$ 1,096,081,545$ & $\$ 648,959,704$ & $\$ 4,156,839,209$ & $\$ 1,670,250$ & $\$ 42,749,261$ & $\$ 120,511,544$ & $\$ 6,402,544,361$ \\
\hline
\end{tabular}

aPolymetallics category added in 1986.

${ }^{\mathrm{b}} \mathrm{Gemstone}$ development category added in 2009.

cSignificant development expenditures were not reported for precious metals in 2015.

- - = Not reported

$W=$ Figures withheld for confidentiality purposes. Expenditures are incorporated into the State total. 
exceeded that of gold since 2014 (appendix B). The value of gold production has decreased 31 percent to $\$ 1.06$ billion in 2017 since 2013's record value of $\$ 1.55$ billion.

Gold production from lode mines in the Eastern Interior and Southeastern regions totaled 818,336 ounces in 2017, of which 80 percent was produced from the Fort Knox and Pogo gold mines in the Eastern Interior region (figure 17). Kensington gold and Greens Creek polymetallic mines in southeastern Alaska, the third and fourth largest gold producers, accounted for the remainder of lode gold production. Placer gold production in 2017 is estimated to be 41,295 ounces or almost five percent of the total gold produced in Alaska (table 12). Employment related to gold production in 2017 is 1,386 full-time-equivalent jobs, almost 41 percent of mining jobs in all sectors (table 2).

The value of Alaska industrial minerals (rock, sand, and gravel) is at least \$11.6 million in 2017. This figure is based on reported production from State lands, the U.S. Bureau of Land Management, and the U.S. Forest Service; it does not include Mental Health Trust lands or lands managed by the State Pipeline Coordinator's Office (figure 18 and appendix C). The total estimated volume

Table 11. Estimated mineral production in Alaska, 2015-2017 a,b

\begin{tabular}{|c|c|c|c|c|c|c|}
\hline Metals & 2015 & 2016 & 2017 & 2015 & 2016 & 2017 \\
\hline Gold (ounces) & 873,984 & 909,242 & 859,631 & $\$ 1,013,875,933$ & $\$ 1,119,280,480$ & $\$ 1,064,039,938$ \\
\hline Silver (ounces) & $15,147,249$ & $16,621,035$ & $16,085,142$ & $237,508,864$ & $246,109,759$ & $245,911,320$ \\
\hline Lead (tons) & 151,247 & 155,409 & 140,683 & $245,126,547$ & $241,931,352$ & $279,092,676$ \\
\hline Zinc (tons) & 686,938 & 700,376 & 649,889 & $1,204,315,037$ & $1,250,186,440$ & $1,595,551,564$ \\
\hline Subtotal & -- & -- & -- & $\$ 2,700,826,381$ & $\$ 2,857,508,031$ & $\$ 3,184,595,498$ \\
\hline \multicolumn{7}{|c|}{ Gemstones and semi-precious stones } \\
\hline $\begin{array}{l}\text { Gemstones and } \\
\text { semi-precious } \\
\text { stones }\end{array}$ & -- & - & -- & $\$--$ & $\$--$ & $\$--$ \\
\hline Subtotal & -- & -- & -- & $\$--$ & $\$--$ & $\$--$ \\
\hline \multicolumn{7}{|l|}{ Industrial Minerals } \\
\hline $\begin{array}{l}\text { Sand and gravel } \\
\text { (million tons) }^{c}\end{array}$ & 5.7 & 6.1 & 3.9 & $\$ 17,176,622$ & $\$ 17,258,291$ & $\$ 11,633,541$ \\
\hline Rock (million tons) & -- & -- & -- & -- & -- & -- \\
\hline Subtotal & & & & $\$ 17,176,622$ & $\$ 17,258,291$ & $\$ 11,633,541$ \\
\hline \multicolumn{7}{|l|}{ Coal and Peat } \\
\hline Coal (tons) ${ }^{d}$ & $1,177,390$ & 930,987 & 873,000 & $\$ 41,208,650$ & $\$ 32,584,545$ & $\$ 30,555,000$ \\
\hline Peat (cubic yards) ${ }^{d}$ & -- & -- & - & -- & -- & -- \\
\hline Subtotal & & & & $\$ 41,208,650$ & $\$ 32,584,545$ & $\$ 30,555,000$ \\
\hline Total & & & & $\$ 2,759,211,653$ & $\$ 2,907,350,867$ & $\$ 3,226,784,039$ \\
\hline
\end{tabular}

aProduction data from DGGS questionnaires, Internet research, interviews with operators, DOT\&PF, and municipalities, regional corporations, and Federal land management agencies.

•Values for selected metals, coal, and industrial minerals production are based on average prices for each year unless public values were provided by the operator. Total value does not match the Mining Revenue in Table 1 due to the incorporation of confidential data in the statewide total. cIndustrial minerals (rock, sand, and gravel) values are combined into the sand and gravel category in 2015-2017.

${ }^{\mathrm{d}} \mathrm{Coal}$ and peat production values are combined in 2012 and 2013. 


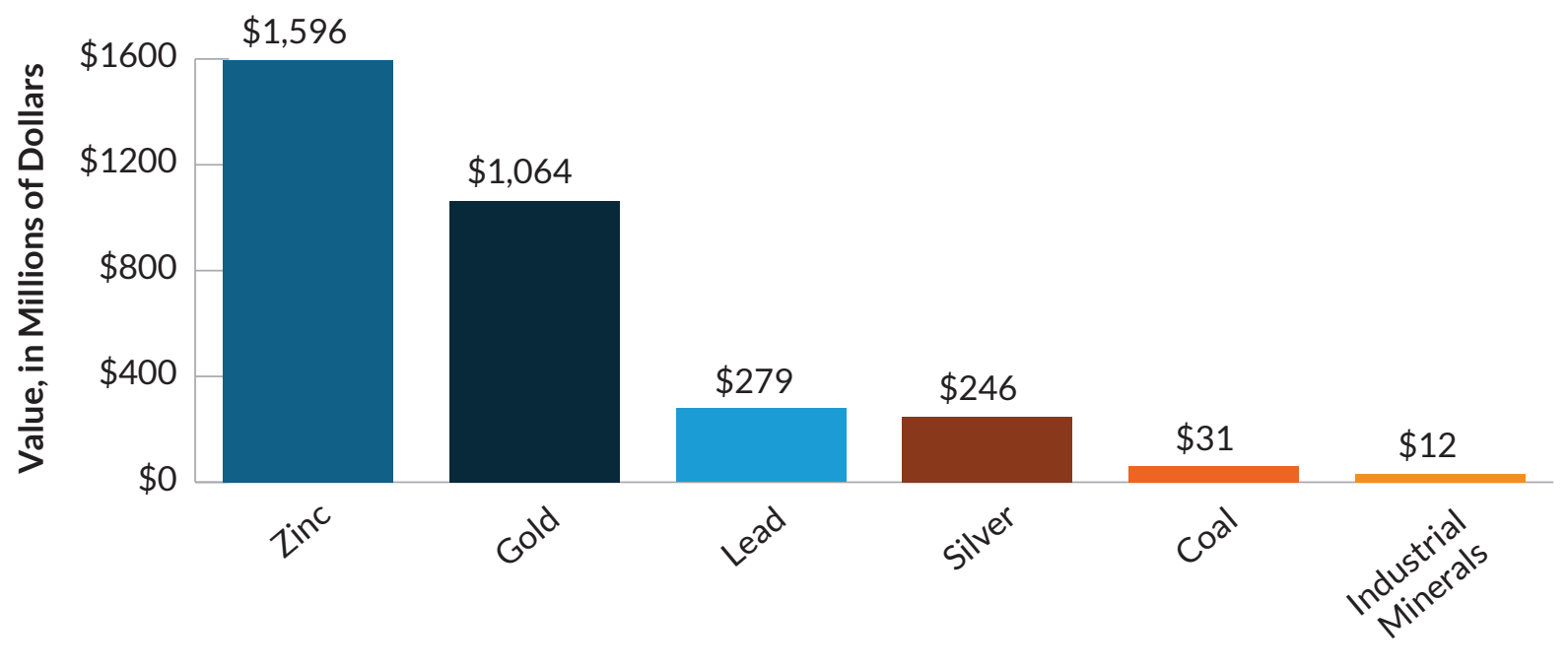

Figure 16. Estimated 2017 mineral production in Alaska by commodity.

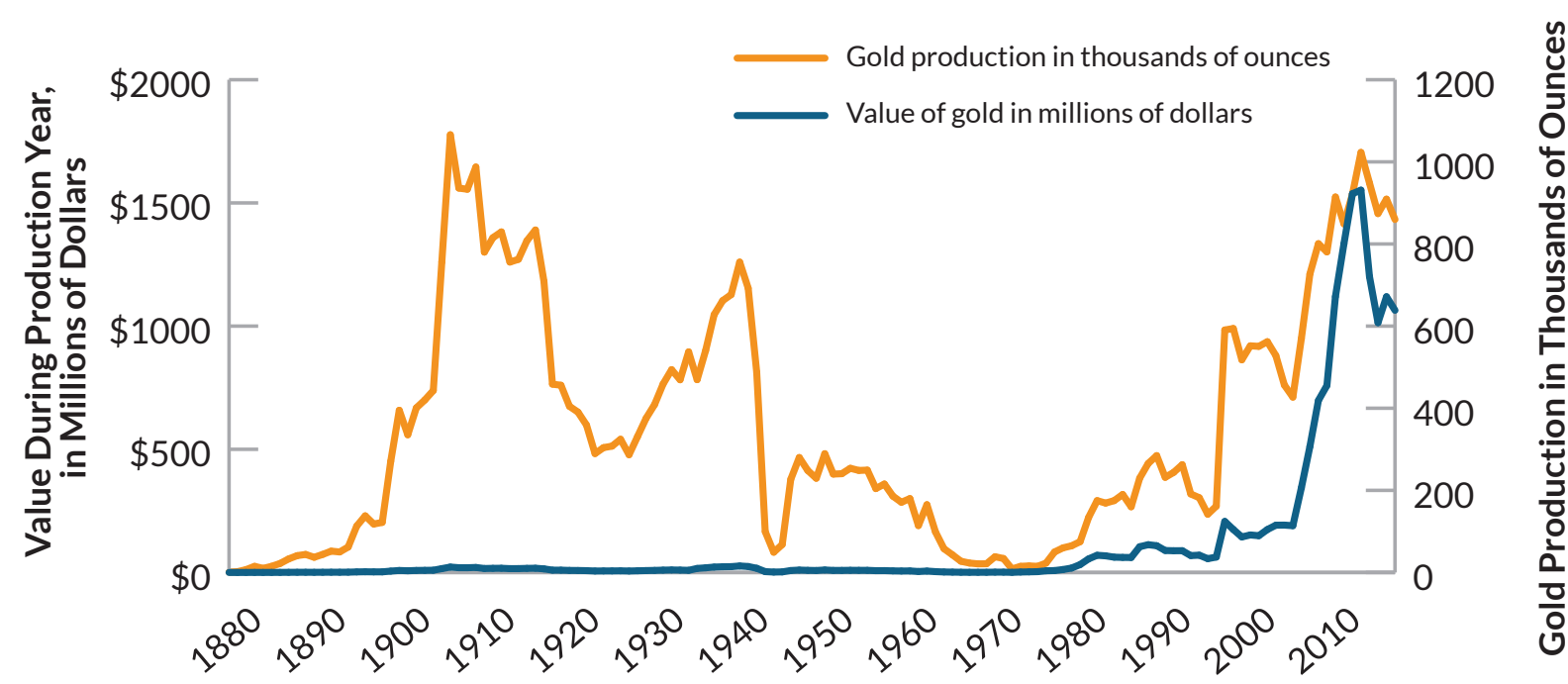

Figure 17. Historical gold production in Alaska, 1880-2017, and corresponding market value.

of industrial minerals sold is 3.9 million tons for the three DNR land offices (table 13), of which the Northern region accounted for 90 percent of industrial minerals sold in the State. The 2017 production volume, value, and employment figures should be considered minimum estimates due to reporting shortfalls. These figures do not account for significant production of industrial minerals on private, Native, and other Federal lands.
Alaska's Office of International Trade reported that Alaska shipped mineral ores and concentrates, metal ores and concentrates, and coal to 16 countries in Europe, North and South America, and the Asia-Pacific region in 2017. The Alaska 2017 export value was $\$ 1.81$ billion, up almost 17 percent from 2016 (table 14). Total exports include copper-gold concentrates from 
Table 12. Production and employment estimates for Alaska placer gold mines, 2014-2017.

\section{4}

2015

2016

2017

\begin{tabular}{lrrrrr}
$\begin{array}{l}\text { Number of placer operations reporting } \\
\text { gross operating income }^{\text {a }}\end{array}$ & 229 & 238 & 236 & 205 \\
\hline Total gross operating income reported $^{\text {a }}$ & $\$ 104,994,998$ & $\$ 78,200,155$ & $\$ 64,803,637$ & $\$ 51,912,476$ \\
\hline $\begin{array}{l}\text { Average yearly price of gold } \\
\text { b }\end{array}$ & $\$ 1,266.40$ & $\$ 1,160.06$ & $\$ 1,250.74$ & $\$ 1,257.12$ \\
\hline $\begin{array}{l}\text { Estimated number of gold ounces } \\
\text { produced }\end{array}$ & 82,908 & 67,410 & 51,812 & 41,295 \\
\hline $\begin{array}{l}\text { Estimated number of full-time- } \\
\text { equivalent employees }\end{array}$ & 216 & 224 & 222 & 193 \\
\hline
\end{tabular}

Estimated number of gold ounces produced is calculated by dividing the total gross income by the average price of gold. This yearly estimate does not take into account gold stockpiled, sold in other years, or paid as wages.

Estimated number of employees is calculated by multiplying the number of placer operations by 4 workers per mine, a factor determined for the October 2014 report The Economic Impacts of Placer Mining in Alaska prepared by McDowell Group,

https://www.dropbox.com/s/wly4yrnmlop59on/AMA\%20Placer\%20Final\%20Report\%2011.15.pdf?dl=0. The factor takes into account unpaid family members and workers paid directly in gold. Full-time-equivalent jobs were calculated by multiplying the total number of workers by a ratio of 86 placer miner working-days per year/365 days. The number of placer miner working-days per year was determined by McDowell Group for the October 2014 report.

alues provided by the Department of Revenue.

b2014-2017 gold prices from Kitco cumulative average London PM fix.

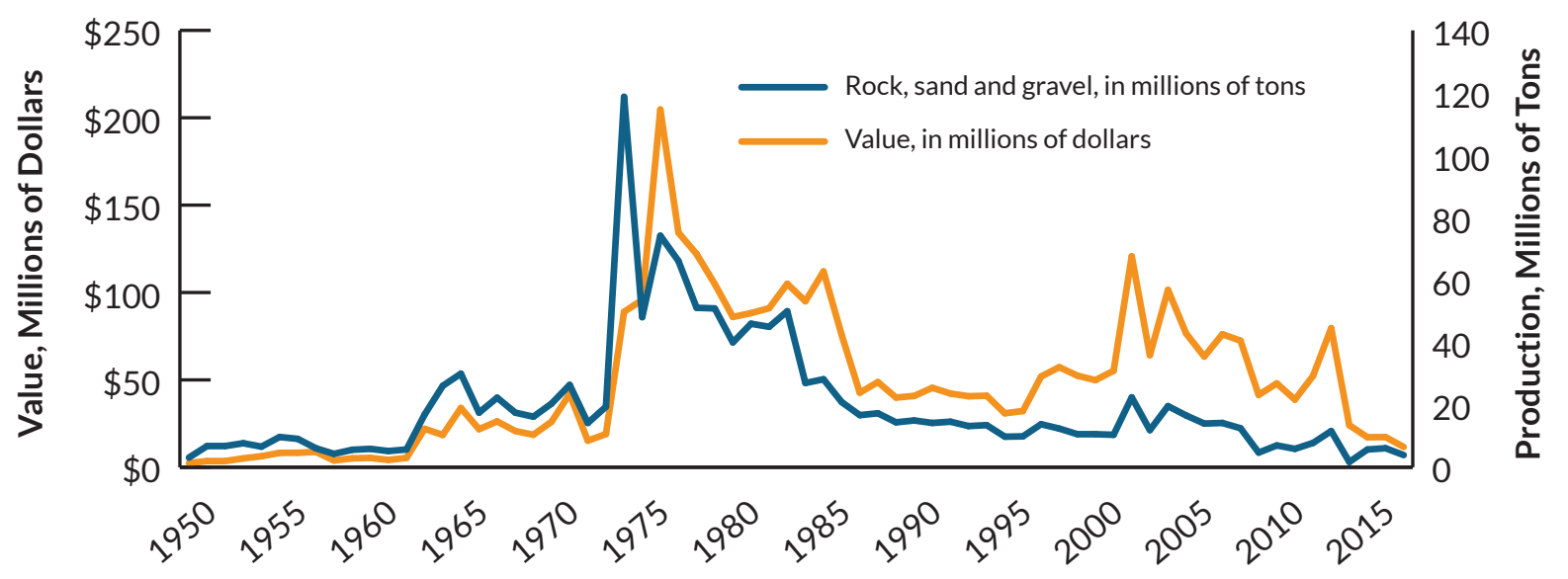

Figure 18. Rock, sand, and gravel production in Alaska, 1950-2017.

the Minto Mine in Yukon Territory, Canada, which were shipped through the AIDEA-owned terminal in Skagway, and coal exported through the Alaska-Railroad-owned coal-loading facility in Seward. The Usibelli Coal Mine did not export coal outside of Alaska in 2017 (figure 19).

Development and production estimates in this report are compiled from a variety of online sources, including annual reports, 10-K reports, and news releases by companies. They are supplemented by questionnaires returned to DGGS by mining companies, as well as personal communications such as phone calls and emails.

Over the last 10 years the majority of development work has been conducted at mine sites, with development activities being integral to the mining operations. Additionally, there have been few purely development-stage projects. The development sector of the mining process refers to building infrastructure or conducting activities 
Table 13. Material (rock, sand, and gravel) sale volumes (in tons) by region reported on State-owned land, excluding Mental Health Trust lands or lands managed by the State Pipeline Coordinator's Office, for 2011-2017. These volumes do not include material produced from private, Native, or Federal lands, which are significant amounts. These figures serve as minimum amounts of material produced.

\begin{tabular}{lccccccc}
\multicolumn{1}{c}{ Regions } & $\mathbf{2 0 1 1}$ & $\mathbf{2 0 1 2}$ & $\mathbf{2 0 1 3}$ & $\mathbf{2 0 1 4}$ & $\mathbf{2 0 1 5}$ & $\mathbf{2 0 1 6}$ & $\mathbf{2 0 1 7}$ \\
$\begin{array}{l}\text { Northern } \\
\text { (Fairbanks office) }\end{array}$ & $2,890,304$ & $\mathbf{3 , 5 0 1 , 3 8 7}$ & $\mathbf{4 , 9 9 1 , 3 4 9}$ & $\mathbf{9 , 2 4 7 , 2 2 3}$ & $\mathbf{3 , 5 5 9 , 5 8 0}$ & $\mathbf{4 , 9 8 9 , 8 5 5}$ & $3,501,847$ \\
\hline $\begin{array}{l}\text { South-Central } \\
\text { (Anchorage office) }\end{array}$ & $\mathbf{7 0 , 4 1 0}$ & $\mathbf{1 , 0 3 5 , 4 5 0}$ & $\mathbf{2 3 5 , 0 5 0}$ & $\mathbf{4 3 3 , 4 3 3}$ & $\mathbf{2 , 1 1 5 , 7 5 0}$ & $\mathbf{3 9 6 , 6 5 7}$ & $\mathbf{3 9 6 , 6 5 7}$ \\
\hline $\begin{array}{l}\text { Southeast } \\
\text { (Juneau office) }\end{array}$ & $\mathbf{7 7 , 9 4 0}$ & 56,115 & $\mathbf{6 9 , 8 6 6}$ & $\mathbf{6 2 , 5 5 9}$ & 50,211 & $\mathbf{1 3 , 2 6 8}$ & $\mathbf{1 3 , 2 6 8}$ \\
\hline Total & $\mathbf{3 , 0 3 8 , 6 5 4}$ & $\mathbf{4 , 5 9 2 , 9 5 2}$ & $\mathbf{5 , 2 9 6 , 2 6 5}$ & $\mathbf{9 , 7 4 3 , 2 1 4}$ & $\mathbf{5 , 7 2 5 , 5 4 1}$ & $\mathbf{5 , 3 9 9 , 7 8 0}$ & $\mathbf{3 , 9 1 1 , 7 7 2}$ \\
\hline
\end{tabular}

Source: Department of Natural Resources, Division of Mining, Land and Water Southeast Regional Office (SERO), South-Central Regional Office (SCRO), and Northern Regional Office (NRO) Material Sale Tracking Spreadsheets. Prepared by Zoya Ponomareva.

DNR material sales volumes and revenues do not correlate, as volumes are attributed to the calendar year in which material was extracted while revenues are tracked on a cash basis (when received), which could be in the subsequent calendar year.

Table 14. Alaska international mineral export values (in millions of dollars).

\begin{tabular}{|c|c|c|c|c|c|}
\hline Year & $\begin{array}{l}\text { Mineral Ores and } \\
\text { Concentrates }^{\mathrm{a}}\end{array}$ & $\begin{array}{c}\text { Canada Copper Ores through } \\
\text { Skagway Terminal }\end{array}$ & $\begin{array}{r}\text { Precious } \\
\text { Metals }^{c}\end{array}$ & Coald $^{d}$ & $\begin{array}{l}\text { Total Value of } \\
\text { Mineral Exports }\end{array}$ \\
\hline 1996 & $\$ 249$ & -- & $>\$ 1$ & $\$ 27$ & $\$ 276$ \\
\hline 1997 & 369 & -- & $>\$ 1$ & 26 & 395 \\
\hline 1998 & 317 & -- & $>\$ 1$ & 8 & 325 \\
\hline 1999 & 359 & -- & $>\$ 1$ & 15 & 374 \\
\hline 2000 & 293 & -- & 1 & 16 & 310 \\
\hline 2001 & 329 & -- & 3 & 17 & 349 \\
\hline 2002 & 380 & -- & 47 & 9 & 436 \\
\hline 2003 & 413 & - - & 84 & 4 & 501 \\
\hline 2004 & 505 & -- & 110 & 14 & 629 \\
\hline 2005 & 511 & -- & 132 & 14 & 657 \\
\hline 2006 & 1,094 & -- & 110 & 10 & 1,214 \\
\hline 2007 & 1,269 & $\$ 16$ & 132 & 5 & 1,406 \\
\hline 2008 & 691 & 103 & 144 & 23 & 858 \\
\hline 2009 & 853 & 64 & 153 & 33 & 1,039 \\
\hline 2010 & 1,336 & 37 & 214 & 25 & 1,575 \\
\hline 2011 & 1,809 & 199 & 267 & 31 & 2,107 \\
\hline 2012 & 1,502 & 169 & 84 & 32 & 1,618 \\
\hline 2013 & 1,495 & 150 & 22 & 27 & 1,543 \\
\hline 2014 & 1,750 & 186 & 11 & 17 & 1,778 \\
\hline 2015 & 1,467 & 99 & 7 & 5 & 1,479 \\
\hline 2016 & 1,523 & 146 & 26 & 2 & 1,551 \\
\hline 2017 & 1,794 & 1 & 13 & 0 & 1,807 \\
\hline
\end{tabular}

Sources: 1996-2013, U.S. Census Bureau, Origin of Movement Series; 2014-2017, Alaska Office of International Trade aHS 26 Mineral Ores: Zinc ores and concentrates, lead ores and concentrates, copper ores and concentrates, silver ores, gold ores and concentrates, zirconium ore (only in 2009), and miscellaneous ores.

balue of Canada copper ores moving through Skagway that are included in Mineral Ores and Concentrates values cHS 71 Precious Metals: Gold doré, precious stones, and wrought jewelry dHS 27 Coal 


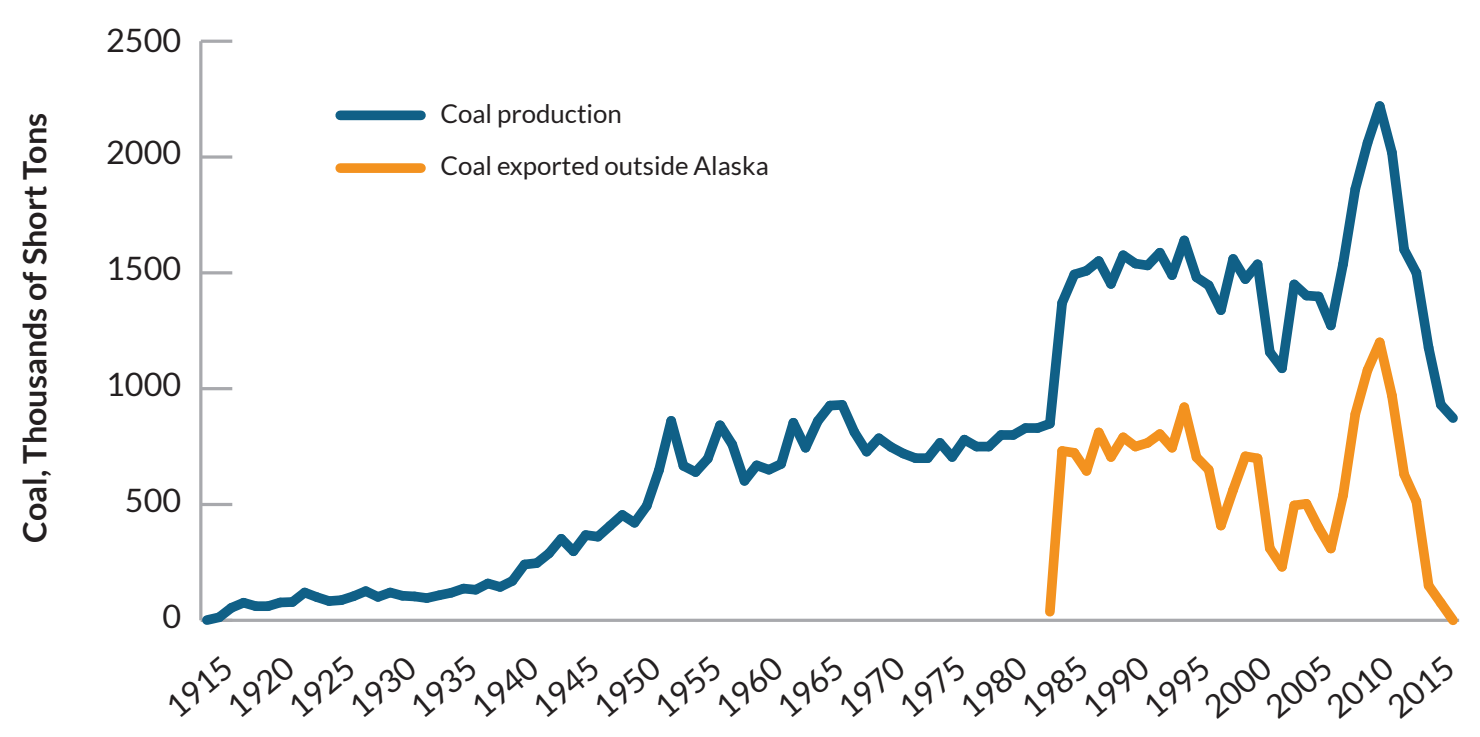

Figure 19. Alaska coal production and exports, 1915-2017.

that facilitate production of mineral products. Development expenditures reflect actual expenditures at mines as well as sustaining capital. Sustaining capital includes equipment replacement and rebuilding, facility upgrades, and other expenditures that must be amortized or depreciated in accordance with tax laws; thus, they are frequently reported as distinct line items in securities filings. Development activities, whether to build a new mine or make improvements to an existing mine, are often precursors to increased annual production or extended mine life. Production expenditures include those costs directly related to the production of metals.

Average metal prices used in this report are based on the average daily London Metal Exchange (LME) price (table 9). Some respondents reported actual unit values received for production; in cases where actual values were available, they were used in place of the average values. This report uses revenue as reported by producers to quantify production values. If unavailable or confidential, the theoretical first market value (estimated gross value of a pure mineral product at first wholesale) is used instead to approximate the value of production; it does not represent actual sales or gross income of producers, does not take into account shipping, smelting, refining, and other costs incurred by the producer, and may significantly overestimate the actual value of the material.

\section{RED DOG MINE}

Red Dog mine in northwest Alaska is one of the world's largest sediment-hosted massive sulfide deposits. It is operated by Teck Alaska Inc. as an open-pit, truck-and-loader operation that uses conventional drill and blast mining methods. On-site mineral-processing facilities employ conventional grinding and sulfide-flotation methods to produce zinc and lead concentrates, which are transported to the coast for shipment during the summer season; Teck Alaska leases the road and port facilities from the Alaska Industrial Development and Export Authority. In 2017 approximately 30 percent of the zinc concentrate was shipped to Teck's metallurgical facilities at Trail, British Columbia and the balance to Asia and Europe; the lead concentrate was shipped to Trail and Asia.

In 2017 Red Dog zinc production decreased to 1.19 billion pounds compared with 1.29 billion pounds in 2016 (table 15). The zinc grade was 15.5 percent, with an 82.1 percent recovery rate. Lead production in 2017 decreased to 245.4 million pounds, compared to 269.6 million pounds 
Table 15. Red Dog mine production statistics, 1989-2017.

\begin{tabular}{|c|c|c|c|c|c|c|c|c|c|}
\hline \multirow[b]{2}{*}{ Year } & \multicolumn{4}{|c|}{ Ore Grade } & \multirow[b]{2}{*}{$\begin{array}{l}\text { Total Tons } \\
\text { Concentrate } \\
\text { Produced }\end{array}$} & \multirow[b]{2}{*}{$\begin{array}{c}\text { Contained } \\
\text { Tons Zinc }\end{array}$} & \multirow[b]{2}{*}{$\begin{array}{l}\text { Contained } \\
\text { Tons Lead }\end{array}$} & \multirow[b]{2}{*}{$\begin{array}{l}\text { Million } \\
\text { Ounces } \\
\text { Silverc }^{c}\end{array}$} & \multirow[b]{2}{*}{ Employees $^{\mathrm{d}}$} \\
\hline & $\begin{array}{l}\text { Tons } \\
\text { Milled }\end{array}$ & $\begin{array}{r}\text { Zinc } \\
(\%)\end{array}$ & $\begin{array}{c}\text { Lead } \\
\text { (\%) }\end{array}$ & $\begin{array}{c}\text { Silver } \\
\text { (oz/ } \\
\text { ton) }\end{array}$ & & & & & \\
\hline 1989 & 33,300 & 20.4 & 7.6 & 3.6 & 8,532 & -- & -- & -- & 228 \\
\hline 1990 & 996,700 & 26.5 & 8.5 & 3.6 & 443,600 & 191,981 & 31,187 & 1.6 & 350 \\
\hline 1991 & $1,599,300$ & 22.5 & 6.6 & 2.8 & 521,400 & 234,510 & 43,815 & 1.46 & 331 \\
\hline 1992 & $1,582,000$ & 19.9 & 6.0 & 2.9 & 474,900 & 231,363 & 15,960 & 1.38 & 349 \\
\hline 1993 & $1,874,600$ & 18.4 & 5.7 & 2.8 & 539,800 & 255,149 & 24,788 & 1.51 & 376 \\
\hline 1994 & $2,339,500$ & 18.8 & 5.7 & 2.8 & 658,000 & 328,160 & 32,775 & 1.84 & 391 \\
\hline 1995 & $2,485,900$ & 19.0 & 5.8 & 2.8 & 753,600 & 358,676 & 55,715 & 3.62 & 397 \\
\hline 1996 & $2,312,600$ & 18.7 & 5.0 & 2.8 & 765,300 & 357,680 & 65,886 & 4.3 & 417 \\
\hline 1997 & $2,127,000$ & 20.3 & 5.2 & 2.9 & 799,400 & 373,097 & 69,284 & 4.27 & 479 \\
\hline 1998 & $2,752,587$ & 21.4 & 5.2 & 2.7 & $1,015,773$ & 490,461 & 80,193 & 5.2 & 466 \\
\hline 1999 & 3,282,788 & 21.3 & 5.2 & 2.7 & $1,207,160$ & 574,111 & 97,756 & 6.21 & 539 \\
\hline 2000 & $3,365,508$ & 21.0 & 4.7 & 2.5 & $1,211,539$ & 585,030 & 91,557 & 5.84 & 536 \\
\hline 2001 & $3,560,430$ & 19.8 & 5.0 & 2.5 & $1,215,837$ & 570,980 & 105,000 & 5.9 & 559 \\
\hline 2002 & $3,489,600$ & 21.1 & 5.4 & 2.7 & $1,366,480$ & 637,800 & 118,880 & 6.75 & 560 \\
\hline 2003 & $3,476,689$ & 21.7 & 6.2 & 3.1 & $1,410,892$ & 638,569 & 137,679 & 7.7 & 388 \\
\hline 2004 & $3,249,613$ & 22.0 & 6.0 & 3.0 & $1,337,545$ & 610,900 & 128,970 & 7.22 & 508 \\
\hline 2005 & $3,402,831$ & 21.7 & 5.6 & 3.0 & 1,330,717 & 626,112 & 112,766 & 1.97 & 449 \\
\hline 2006 & $3,569,280$ & 20.6 & 6.1 & 3.0 & $1,378,384$ & 614,538 & 136,135 & 7.62 & 457 \\
\hline 2007 & $3,726,910$ & 20.2 & 6.1 & 3.1 & $1,428,014$ & 633,511 & 146,152 & 11.55 & 459 \\
\hline 2008 & $3,306,934$ & 20.1 & 6.0 & 3.1 & $1,273,885$ & 567,911 & 135,143 & 7.5 & 475 \\
\hline 2009 & $3,729,119$ & 20.9 & 5.9 & 3.1 & $1,445,870$ & 642,096 & 144,954 & 8.12 & 413 \\
\hline 2010 & $3,937,456$ & 18.2 & 5.4 & 3.1 & $1,300,694$ & 593,043 & 121,144 & 6.78 & 550 \\
\hline 2011 & $4,048,000$ & 19.1 & 5.0 & 3.0 & $1,182,060$ & 572,208 & 84,033 & 5.19 & 586 \\
\hline 2012 & $3,941,000$ & 18.2 & 4.6 & 3.0 & $1,134,415$ & 529,157 & 95,282 & 5.89 & 530 \\
\hline 2013 & $4,243,899$ & 17.0 & 3.9 & NA & $1,271,221$ & 607,704 & 106,594 & 6.1 & 550 \\
\hline 2014 & $4,739,302$ & 16.6 & 4.4 & NA & $1,409,511$ & 656,971 & 135,032 & 7.56 & 639 \\
\hline 2015 & $4,437,950$ & 14.1 & 2.9 & NA & $1,351,221$ & 625,004 & 129,630 & 6.7 & 630 \\
\hline 2016 & $4,684,823$ & 17.1 & 4.9 & NA & 1,411,029 & 642,647 & 134,813 & 7.34 & 600 \\
\hline 2017 & 4,706,864 & 15.5 & 5.0 & NA & 1,322,302 & 597,342 & 122,687 & 7.7 & 715 \\
\hline Total & $91,002,483$ & & & & $30,969,081$ & $14,346,711$ & $2,703,809$ & 154.82 & \\
\hline
\end{tabular}

aRevised slightly from Special Report 51, Alaska’s Mineral Industry 1995, based on new company data.

bTotals for years 1990 through 1995 include bulk concentrate. Total for 2013 estimated from total metal produced for 2013.

'Estimate calculated at 56 ounces per ton of lead metal produced from 1990 to 2004 and 2006; as reported credit for 2005, net of treatment charges; calculated at 3.1 ounces per ton of ore for 2007; estimated as proportional with increase in zinc and lead in 2013; as reported in 2014, 2016, and 2017; calculated based on recoverable silver from reported lead concentrate recovered in 2015.

In ncludes contract employees, if known.

- - = No concentrate produced

NA = Not available 
in 2016. The lead grade was 5.0 percent, with a 52.3 percent recovery rate. In 2017 Teck Alaska employed 715 staff (including contractors), mined 12.9 million tons of material, and milled 4.7 million tons. Teck Alaska sold 1.18 billion pounds of zinc and 249.3 million pounds of lead from Red Dog mine in 2017. Teck Alaska spent \$26.9 million in sustaining capital at Red Dog, gross profits before depreciation and amortization were $\$ 747$ million, and final gross profits were $\$ 672$ million.

In accordance with the operating agreement between Teck and land-owner NANA Regional Corporation Inc. (NANA) governing the Red Dog mine, Teck pays a royalty based on net proceeds of production each quarter. This royalty rate increases by 5 percent every five years to a maximum of 50 percent. The royalty rate through September 30, 2017, was 30 percent and increased to 35 percent effective October 1, 2017. Royalty costs in 2017 were $\$ 317$ million. Additionally, in early 2017, Teck Alaska and the North West Arctic Borough agreed to a new 10-year payment-in-lieu-of-taxes (PILT) agreement, which was subsequently signed during the second quarter of the year. Under the new agreement, PILT payments to the Borough, based on the assessed property value of the mine, increase by approximately $\$ 4$ million to between $\$ 14$ million and $\$ 18$ million per year. In addition, Teck Alaska will make annual payments to a separate fund aimed at social investment in villages in the region. These payments, based on mine profitability, will be between $\$ 4$ million and $\$ 8$ million per year, with $\$ 11$ million invested in the first year.

Red Dog mine consists of three ore bodies: Main (exhausted in early 2012), Aqqaluk (currently active), and Qanaiyaq (initial mining in 2017) (figure 20). Reserves and resources for the Aqqaluk and Qanaiyaq deposits as of yearend 2017 are tabulated in appendix D. During the first quarter of 2017, ore from the higher-grade Qanaiyaq deposit was introduced to supplement declining-grade ore from the Aqqaluk pit as planned; however, mill performance was adversely affected as the initial Qanaiyaq ores are highly oxidized and metallurgically complex. For the remainder of 2017, less Qanaiyaq ore was added to the mill feed mix to help improve recoveries and concentrate grades as Teck gained experience working with the ore. Qanaiyaq ore is expected to become less oxidized as the pit is deepened, and is planned to be about a 20-percent feed source for the next 10 years.

Teck Alaska also worked on optimizing flotation at Red Dog. Zinc rougher froth cameras were updated in early 2017 to LED-illuminated, internet-protocol-based cameras, which constantly monitor the rougher circuit and collect data related to froth characteristics, allowing for optimization of circuit recovery. In the future, Teck plans to operate froth cameras with an Expert system.

To be more selective of what materials are brought from the mine to the mill, Teck experimented with X-ray fluorescence (XRF) sensors mounted on the buckets of loaders, which will enable material sorting on a bucket-by-bucket basis. In 2017 a pilot trial of ShovelSense XRF sensor was conducted using 15 ore types defined as representative of Red Dog mine, and results were compared to representative bulk-sample

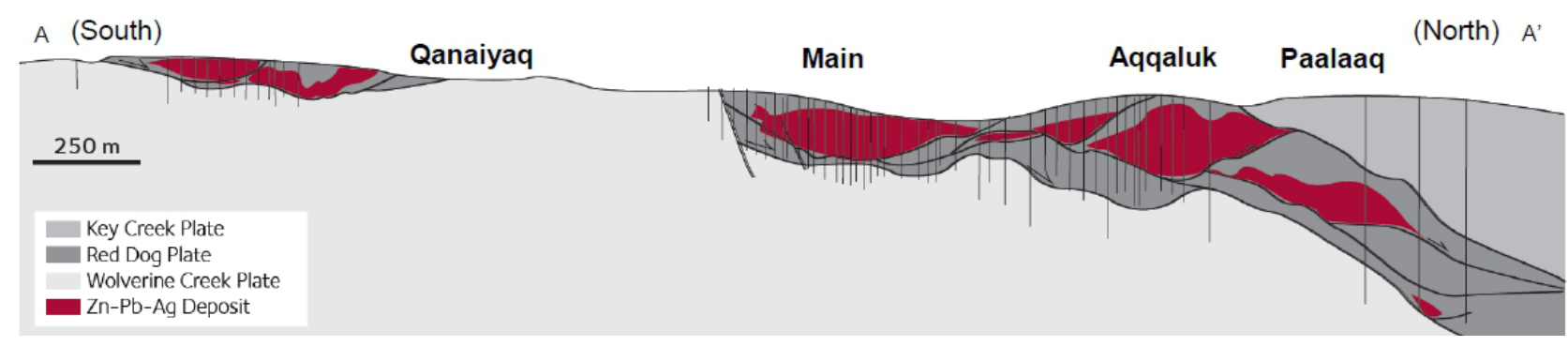

Figure 20. Cross section through Red Dog mine ore bodies looking west. Figure source: Teck Resources Limited; last accessed October 22, 2018; https://www.teck.com/investors/presentations-webcasts/. 
assays. Preliminary results are positive; they suggest a strong correlation between the ShovelSense XRF sensor response and mineral composition, so Teck plans to pursue further testing of this technology. Teck is also developing ore-storing technology that could convert currently defined waste rock into ore.

In September 2017, Teck initiated a mill-upgrade project which is expected to increase average mill throughput by about 15 percent over the remaining mine life, helping to offset lower grades and harder ore in the Aqqaluk pit. This project is expected to be complete by the end of 2019 at a capital cost of $\$ 110$ million. Because the upgrade project will permit lower grade material to be processed, the current mine life, based on existing developed deposits, will remain unchanged through 2031.

\section{FORT KNOX MINE}

The Fort Knox plutonic-hosted gold mine located 20 miles north of Fairbanks is operated by Fairbanks Gold Mining, Inc., a wholly owned subsidiary of Kinross Gold Corporation. The

Table 16. Fort Knox mine production statistics, 1996-2017.

\begin{tabular}{|c|c|c|c|c|c|c|c|c|c|}
\hline \multirow[b]{2}{*}{ Year } & \multicolumn{3}{|c|}{ Tons mined (ore+waste) } & \multicolumn{3}{|c|}{ Tons Milled (ore) } & \multirow{2}{*}{$\begin{array}{l}\text { Tons } \\
\text { Placed } \\
\text { on Heap } \\
\text { Leach }^{\mathrm{b}}\end{array}$} & \multirow{2}{*}{$\begin{array}{l}\text { Ounces } \\
\text { Gold } \\
\text { Produced }\end{array}$} & \multirow[b]{2}{*}{ Employees } \\
\hline & Fort Knox & $\begin{array}{l}\text { True } \\
\text { North }^{\mathrm{a}}\end{array}$ & Total & Fort Knox & $\begin{array}{l}\text { True } \\
\text { North }^{\mathrm{a}}\end{array}$ & Total & & & \\
\hline 1996 & $16,684,000$ & 0 & $16,684,000$ & 769,700 & 0 & 769,700 & & 16,085 & 243 \\
\hline 1997 & $32,380,000$ & 0 & $32,380,000$ & $12,163,151$ & 0 & $12,163,151$ & & 366,223 & 249 \\
\hline 1998 & $33,294,000$ & 0 & $33,294,000$ & $13,741,610$ & 0 & $13,741,610$ & & 365,320 & 245 \\
\hline 1999 & $30,350,000$ & 0 & $30,350,000$ & $13,819,010$ & 0 & $13,819,010$ & & 351,120 & 253 \\
\hline 2000 & $35,600,000$ & 0 & $35,600,000$ & $15,000,000$ & 0 & $15,000,000$ & & 362,929 & 253 \\
\hline 2001 & $25,957,900$ & $8,448,400$ & $34,406,300$ & $13,282,614$ & $2,377,386$ & $15,660,000$ & & 411,220 & 360 \\
\hline 2002 & $24,583,500$ & $11,461,000$ & $36,044,500$ & $11,887,200$ & $3,371,800$ & $15,259,000$ & & 410,519 & 360 \\
\hline 2003 & $30,597,940$ & $12,707,100$ & $43,305,040$ & $11,473,000$ & $3,611,682$ & $15,084,682$ & & 391,831 & 316 \\
\hline 2004 & $44,187,000$ & $3,763,000$ & $47,950,000$ & $12,917,966$ & $1,675,854$ & $14,593,820$ & & 338,334 & 427 \\
\hline 2005 & $63,248,000$ & 0 & $63,248,000$ & $14,384,842$ & 0 & $14,384,842$ & & 329,320 & 411 \\
\hline 2006 & $51,070,000$ & 0 & $51,070,000$ & $14,839,297$ & 0 & $14,839,297$ & & 333,383 & 406 \\
\hline 2007 & $45,940,000$ & 0 & $45,940,000$ & $14,021,400$ & 0 & $14,021,400$ & & 338,459 & 399 \\
\hline 2008 & $46,300,000$ & 0 & $46,300,000$ & $15,110,000$ & 0 & $15,110,000$ & & 329,105 & 449 \\
\hline 2009 & $27,585,000$ & 0 & $27,585,000$ & $17,884,000$ & 0 & $17,884,000$ & & 263,260 & 500 \\
\hline 2010 & $42,400,000$ & 0 & $42,400,000$ & $14,560,000$ & 0 & $14,560,000$ & & 349,729 & 525 \\
\hline 2011 & $34,550,000$ & 0 & $34,550,000$ & $14,880,000$ & 0 & $14,880,000$ & & 289,794 & 522 \\
\hline 2012 & $63,120,000$ & 0 & $63,120,000$ & $14,550,000$ & 0 & $14,550,000$ & & 359,948 & 565 \\
\hline 2013 & $63,280,000$ & 0 & $63,280,000$ & $13,960,000$ & 0 & $13,960,000$ & & 428,822 & 629 \\
\hline 2014 & $49,240,000$ & 0 & $49,240,000$ & $14,920,000$ & 0 & $14,920,000$ & $28,500,000$ & 387,285 & 649 \\
\hline 2015 & $60,860,000$ & 0 & $60,860,000$ & $14,820,000$ & 0 & $14,820,000$ & $27,700,000$ & 401,553 & 657 \\
\hline 2016 & $65,240,000$ & 0 & $65,240,000$ & $14,570,000$ & 0 & $14,570,000$ & $32,124,000$ & 409,845 & 660 \\
\hline 2017 & $60,450,000$ & 0 & $60,450,000$ & $13,744,703$ & 0 & $13,744,703$ & $22,340,517$ & 381,115 & 627 \\
\hline Total & $946,917,340$ & $36,379,500$ & $983,296,840$ & $297,298,493$ & $11,036,722$ & $308,335,215$ & $215,064,517$ & $7,615,199$ & \\
\hline
\end{tabular}

aTrue North Mine started production in 2001 and suspended production in 2004.

bWalter Creek Heap leach facility started production in 2009, but was not tracked until 2014. Total includes 104.4 million tons placed on heap leach from 2009 through 2013. 
open-pit and truck-and-shovel operation uses carbon-in-pulp, heap leach, and gravity processes to recover gold. Fort Knox gold production for 2017 totaled 381,115 ounces, and Kinross sold 381,779 ounces of gold (table 16). Production decreased from 2016 mainly due to fewer tons of material placed on the heap leach pad, but was partially offset by an increase in mill grade (photo 22). Fort Knox’s 2017 production cost of sales were \$239.9 million, or \$628 per ounce of gold sold. In 2017 Kinross employed 627 people, mined 29,057,994 tons of material, processed $13,744,703$ tons of ore through the mill, and processed 22,340,517 tons of ore on the heap leach pad at Fort Knox. Mill grade averaged 0.027 ounce of gold per ton with an 82 percent recovery rate, and the heap leach grade averaged 0.008 ounce of gold per ton. Capital expenditures were $\$ 102.1$ million, and depreciation, depletion, and amortization expenses totaled
$\$ 86.6$ million. Fort Knox paid $\$ 8.7$ million in property taxes during 2017.

In December 2017, Kinross Gold Corporation gained mineral rights to a 709-acre parcel of land, known as the Gilmore land, located immediately west of Fort Knox mine. The Gilmore land was conveyed to the State of Alaska by the United States on December 11, 2017. Upon conveyance, the company's existing State mining claims at Gilmore came into effect. As a result, Kinross added 2.1 million ounces of gold to measured and indicated resources and 300,000 ounces of gold to inferred resources at Fort Knox. This estimate is based on a 2014 drill program of 239,500 feet in 205 holes targeting the westward continuation of the Fort Knox orebody onto Gilmore land. In 2017 Kinross also converted approximately 260,000 ounces of mineral resources, primarily from the east wall of the

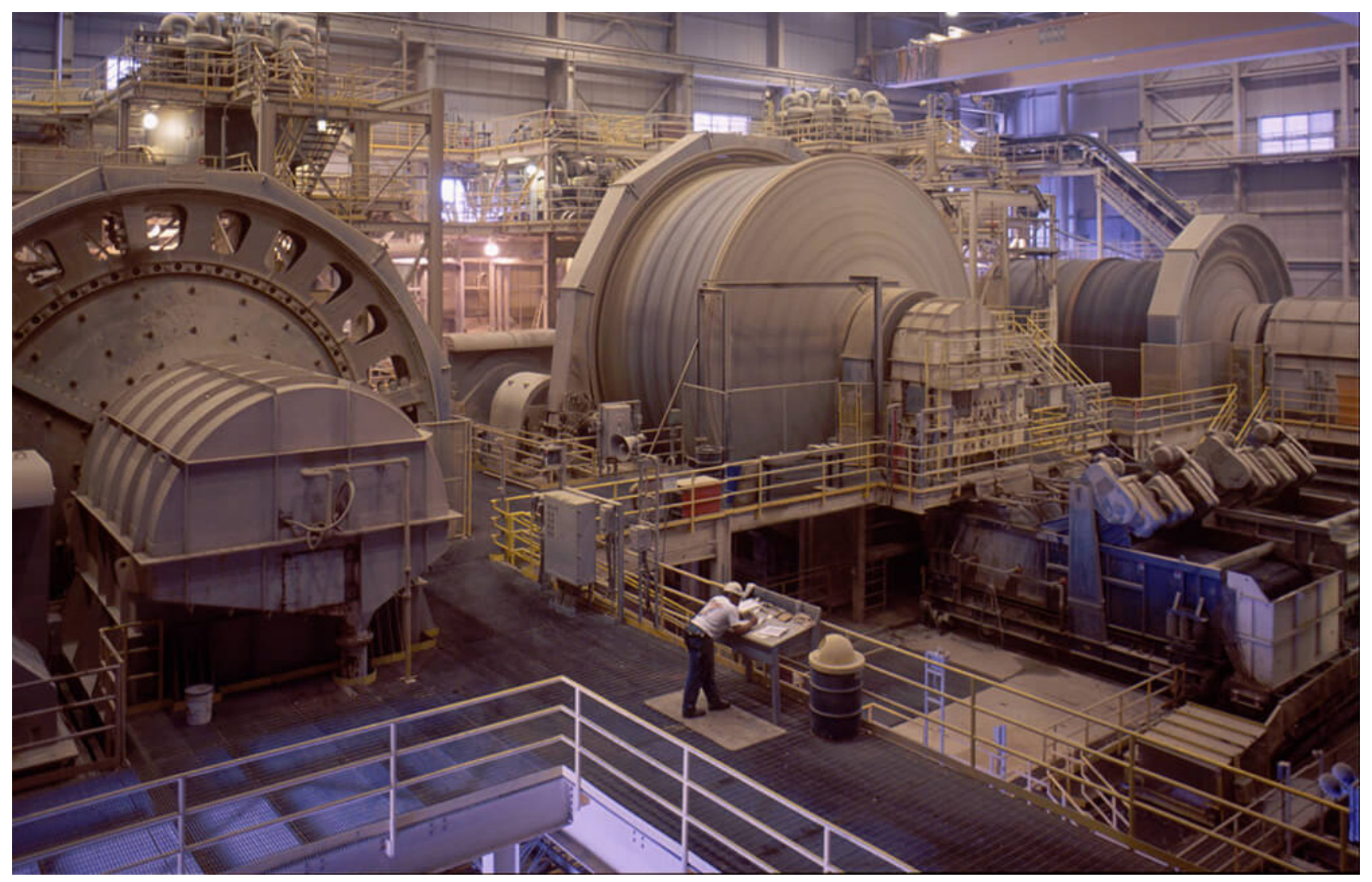

Photo 22. Kinross Gold Corporation's Fort Knox mine north of Fairbanks processed 13,744,703 tons of ore through the mill, at an average grade of 0.027 ounce of gold per ton with an 82 percent recovery rate. Photo from: Kinross Gold Corporation; last accessed October 19, 2016; http://www.kinross.com/news-and-investors/mediagallery/default.aspx\#null-fortknox. 
Fort Knox pit, to proven and probable reserves. The conversion offset some of the reserve depletion in 2017 and resulted in an increase to Fort Knox's estimated mine life of approximately one year. Fort Knox mine reserves and resources as of December 31, 2017 are tabulated in appendix D.

Kinross commenced a Gilmore feasibility study in 2017 that will analyze a layback of the current Fort Knox pit to access known mineralization on Fort Knox and Gilmore land to potentially extend the mine's life. Further drilling and engineering are planned at Gilmore to evaluate the potential of upgrading a significant portion of the site's estimated measured and indicated resources and adding to its inferred mineral resource estimate. The company initiated the permitting process for mining at Gilmore.

In 2017 Kinross implemented a new core-logging program and geologists re-logged 80,000 feet of historical core. Mineralization at Fort Knox mine is hosted in southeast-northwest-trending shears and stockwork veins that are generally less than 3 feet wide. Kinross utilized both short-wave infrared (SWIR) and hyperspectral technology to map alteration. SWIR spectral-data interpretations distinguished various clay minerals and determined that elevated illite is spatially associated with gold mineralization; this technique identified previously unrecognized zones of alteration. Hyperspectral data were collected on the west wall of the open pit to identify alteration minerals for fault-model validation. Paragenetically early background chlorite alteration in the granite was later overprinted by faults with differing alteration mineralogy. Cross-cutting relationships between faults were determined and correlated to alteration mineralogy and gold-bearing zones.

\section{POGO MINE}

The Pogo gold mine in interior Alaska is owned and operated by Sumitomo Metal Mining Pogo LLC, a joint venture between 85 percent owner Sumitomo Metal Mining C. Ltd. and 15 percent owner Sumitomo Corporation.* The deposit consists of a set of structurally controlled, gold-bearing quartz veins that are being mined underground with a cut-and-fill operation. Gravity, flotation, and cyanide leaching processes are used to recover gold. The Pogo property contains five known deposits: Liese Zone, North Zone, East Deep, South Pogo, and 4021. In 2017 Sumitomo continued to mine the Liese Zone L1, L2, and L3 gold-bearing quartz veins hosted by low-angle shear zones, as well as the East Deep vein. They will be sending North Zone material to the mill in the near future.

Pogo mine produced 271,273 ounces of gold in 2017 (table 17). The mine moved 1,602,107 tons of ore and waste materials; 974,940 tons were milled, and 12,990,646 cubic feet of paste fill was placed back in the underground workings. The average ore grade was 0.314 ounce per ton at a recovery rate of 88.1 percent. Sumitomo had 320 employees and more than 150 contract employees in 2017. Pogo mine reserves and resources as of year-end 2017 are 760,000 ounces of gold in proven and probable reserves, and 3,340,000 ounces of gold in the measured, indicated, and inferred resource category (appendix D). Pogo is permitted to operate through 2019.

Researchers at the University of Alaska Fairbanks developed various data-mining techniques to identify sensor-calibration errors of very low magnitude ( 2 percent) in a carbon-in-pulp circuit at the Pogo gold-processing facility. The sensors are used in process control and monitoring, and the research is being conducted to improve mineral recoveries.

\section{USIBELLI COAL MINE}

Usibelli Coal Mine Inc. is a local, family-owned coal mining company in production since 1943. The company mines coal from the Miocene Suntrana Formation from leases on State-owned lands in the Healy area. Usibelli's main leases are in the Hoseanna Creek and Jumbo Dome areas. There are four active and past coal resources: Two Bull Ridge, Gold Run Pass, Jumbo Dome, and Poker Flat. The company 
is currently mining Two Bull Ridge, which has more than 10 million tons of coal slated for mining. The Two Bull Ridge resource has 3.5-5 cubic yards of overburden for each ton of coal, which is contained in multiple seams. Number 3 seam averages 18 feet thick, number 4 seam is up to 32 feet thick, and number 6 seam averages 21 feet thick. Gold Run Pass is nearing completion of its mining life, with four of five reclamation stages complete. The Jumbo Dome mine region contains approximately 250 million tons of coal, about 80 million tons of which have been permitted. Number 4 seam averages 40 feet thick with 25 to 75 feet of overburden above it, and number 3 seam averages 30 feet thick with 35 feet of overburden between it and number 4 seam. Stripping ratios are 0.5 cubic yards of overburden per one ton of coal. Poker Flats, now fully reclaimed, produced about 27 million tons of coal beginning in the 1970s. All coal is subbituminous, low-ash, and extremely low in sulfur content.

In 2017 Usibelli employed 115 full-time-equivalent employees, and produced 70 percent of its coal from its Jumbo Dome mine site near Healy and 30 percent from the Badlands area, for a total output of 873,000 tons, down from 930,987 tons in 2016. The majority of Usibelli's coal is used for in-state electrical power generation at interior Alaska coal-fired power plants. The University of Alaska Fairbanks is constructing a new boiler and 17-megawatt turbine generator, Eielson Air Force Base is upgrading multiple boilers, and Golden Valley Electric Association is in the process of commissioning the Healy Number 2 power plant, a 50-megawatt coal-fired electrical plant at the mouth of the Usibelli mine, which is projected to use about 200,000 tons of coal per year.

\section{KENSINGTON MINE}

Kensington mine, 100-percent owned by Coeur Alaska, Inc., a wholly-owned subsidiary of Coeur Mining, Inc., is located 45 miles northnorthwest of Juneau; it falls within the Berners Bay mining subdistrict at the northern-most edge of the Juneau Gold Belt. The underground

Table 17. Pogo mine production statistics, 2006-2017.

\begin{tabular}{ccccccc} 
Year & $\begin{array}{c}\text { Tons Ore } \\
\text { Mined }\end{array}$ & $\begin{array}{c}\text { Tons Ore } \\
\text { Milled }\end{array}$ & $\begin{array}{c}\text { Ounces } \\
\text { of Gold } \\
\text { Recovered }\end{array}$ & Recovery (\%) & $\begin{array}{c}\text { Head Grade } \\
\text { Gold (oz/ } \\
\text { ton) }\end{array}$ & Employees $^{\text {a }}$ \\
\hline 2006 & 447,129 & 338,000 & 113,364 & 85.0 & 0.395 & 477 \\
\hline 2007 & 715,665 & 715,400 & 259,820 & 84.4 & 0.430 & 339 \\
\hline 2008 & 882,400 & 818,237 & 347,219 & 83.8 & 0.506 & 285 \\
\hline 2009 & 944,823 & 930,836 & 389,808 & 88.2 & 0.475 & 272 \\
\hline 2010 & 900,585 & 947,189 & 383,434 & 89.6 & 0.452 & 300 \\
\hline 2011 & 892,725 & 929,020 & 325,708 & 89.6 & 0.392 & 310 \\
\hline 2012 & 815,922 & 875,351 & 315,886 & 89.7 & 0.402 & 335 \\
\hline 2013 b & 963,229 & 875,351 & 337,393 & 90.2 & 0.395 & 320 \\
\hline 2014 & 972,406 & 967,230 & 342,147 & 89.0 & 0.396 & 320 \\
\hline 2015 & -- & -- & 283,000 & -- & -- & 350 \\
\hline 2016 & $1,515,117$ & 941,856 & 269,342 & 86.1 & 0.331 & 470 \\
\hline 2017 & $1,602,107$ & 974,940 & 271,273 & 88.1 & 0.314 & 470 \\
\hline Total & $\mathbf{1 0 , 6 5 2 , 1 0 8}$ & $\mathbf{9 , 3 1 3 , 4 1 0}$ & $\mathbf{3 , 6 3 8 , 3 9 4}$ & & & \\
\hline
\end{tabular}

alncludes contract employees, if known.

bSilver production of 32,000 ounces was reported in 2013.

- - = Not reported 
Kensington mine commenced commercial production on July 3, 2010, and consists of at least three major, structurally controlled, orogenic gold-vein systems (Kensington Main, Jualin, Raven), which are being mined by long-hole stoping and drift-and-fill methods. Gold is recovered

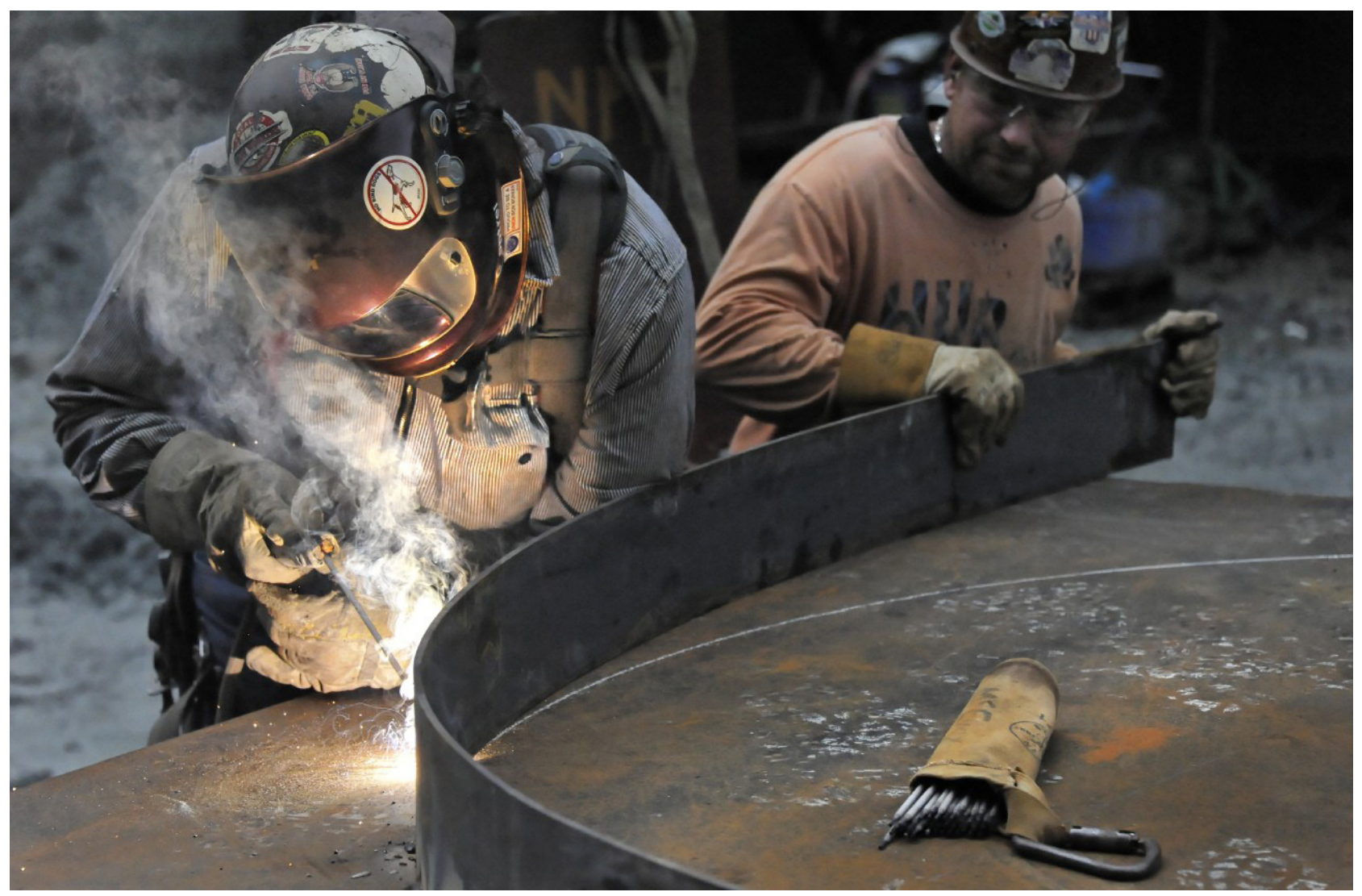

Photo 23. Coeur Alaska employed 367 full-time, year-round workers at the Kensington mine near Juneau in 2017. Out of Alaska boroughs or census areas, the City and Borough of Juneau had the highest number of mining jobs in the state at 821 jobs. Photo from: Coeur Mining, Inc.; last accessed October 1, 2018; https://coeur.com/ gallery/album-4/lg/ DSC1414a-Alaska-small.jpg.

Table 18. Kensington mine production statistics, 2010-2017.

\begin{tabular}{ccccc} 
Year & $\begin{array}{c}\text { Ore } \\
\text { (tons milled) }\end{array}$ & $\begin{array}{c}\text { Ore Grade Gold } \\
\text { (oz/ton) }\end{array}$ & $\begin{array}{c}\text { Gold Recovery } \\
\text { (\%) }\end{array}$ & $\begin{array}{c}\text { Gold Produced } \\
\text { (oz) }\end{array}$ \\
\hline $2010^{a}$ & 174,028 & 0.28 & 89.9 & 43,143 \\
\hline 2011 & 415,340 & 0.23 & 92.7 & 88,420 \\
\hline 2012 & 394,780 & 0.22 & 95.6 & 82,125 \\
\hline 2013 & 553,717 & 0.21 & 96.6 & 114,821 \\
\hline 2014 & 635,960 & 0.20 & 94.1 & 117,823 \\
\hline 2015 & 659,786 & 0.20 & 94.9 & 128,865 \\
\hline 2016 & 620,209 & 0.21 & 94.7 & 124,331 \\
\hline 2017 & 668,727 & 0.18 & 93.5 & $\mathbf{8 1 4 , 6 2 2}$ \\
\hline Total & $\mathbf{4 , 1 2 2 , 5 4 7}$ & & & \\
\hline
\end{tabular}


in a flotation mill that produces a concentrate that is sold to third-party smelters. Kensington mine reserves and resources as of December 31, 2017 are tabulated in appendix D.

In 2017 Coeur Alaska had 367 full-time, year-round employees and was the second-largest private employer in the City and Borough of Juneau in terms of payroll (photo 23). It was one of the two largest property taxpayers as well. In 2017 Coeur Alaska processed 668,727 tons of material through their mill at an average grade of 0.18 ounce of gold per ton with a 93.5 percent recovery rate (table 18). Full-year production of 115,094 ounces of gold was below Coeur's guidance range due to lower-than-expected grades in the first nine months of the year. Coeur sold 125,982 ounces of gold for metal sales of $\$ 146.6$ million. Fullyear gold sales were higher than production due to reductions in inventory throughout the year, particularly in the first quarter. Costs applicable to sales were $\$ 116.1$ million, adjusted average cash costs applicable to sales for the year were $\$ 922$ per ounce of gold, and total sustaining and development capital expenditures were $\$ 36.8$ million.

At Kensington, development ore was mined and stockpiled from the high-grade Jualin deposit after two years of underground development activities. Although grades from the Kensington Main deposit were lower than expected for the first part of the year, fourth-quarter gold production increased 27 percent quarter-over-quarter, primarily the result of mining the higher-grade Raven zone, which drove average grades 29 percent higher to 0.22 ounce of gold per ton. During the fourth quarter, mining of development ore continued at Jualin, where production is expected to accelerate throughout 2018 as Coeur dewaters the mine area to facilitate more efficient drilling, development, and mining activities.

In 2017 Coeur focused on both resource conversion and expansion of the Jualin deposit as well as resource conversion at Raven. Capitalized drilling was directed at infill drilling in the southern and deeper portions of the Kensington Main deposit as well as the Raven vein. Coeur invested
$\$ 5.7$ million in conversion drilling and completed 61,939 feet to expand and define mineralization in the Kensington Main and Raven deposits.

\section{GREENS CREEK MINE}

Hecla Mining Company reported production of 8,351,882 ounces of silver in 2017 from their underground Greens Creek volcanogenic massive sulfide mine in southeast Alaska, a decrease of 9.7 percent compared to the record silver production of 2016 (table 19). Gold production in 2017 was 50,854 ounces, a decrease of 5.7 percent from 2016. The decrease in silver production resulted from lower grades, and gold production was lower due to lower recoveries and slightly lower ore grades. The mine also yielded 36 million pounds of lead and 105.1 million pounds of zinc. The mill operated at an average of 2,300 tons per day for the year, for a total of 839,589 tons of ore processed; a record, which is about 15 percent greater than the throughput when Hecla became the operator in 2008. Mining and milling costs per ton were $\$ 70.86$ and $\$ 32.38$, respectively. Ore grades milled were 12.88 ounces of silver per ton, 0.09 ounce of gold per ton, 2.72 percent lead, and 7.25 percent zinc. The cost of sales and other direct production costs and depreciation, depletion, and amortization for 2017 was $\$ 201,803,000$. The total cash cost, after byproduct credits, was $\$ 0.71$ per ounce of silver. The all-in sustaining capital, after byproduct credits, was $\$ 5.76$ per ounce of silver. For the full year of 2017, Greens Creek generated cash provided by operating activities of approximately $\$ 136.7$ million and spent $\$ 35.3$ million on capital additions to properties, plants, and equipment, resulting in free cash flow of $\$ 101.4$ million. Hecla had 423 full-time employees at Greens Creek in 2017, not including contractors. Definition core drilling, totaling 129,715 feet in 2017, refined the resources of the East Ore, Deep SW, Deep 200 South, Gallagher, 9A, NWW, SW, SW Bench, West, and Upper Plate ore zones. Greens Creek mine reserves and resources as of December 31, 2017 are tabulated in appendix D. 
Table 19. Greens Creek mine production statistics, 1989-2017.

\begin{tabular}{|c|c|c|c|c|c|c|c|c|}
\hline \multirow[b]{2}{*}{ Year } & \multirow[b]{2}{*}{$\begin{array}{l}\text { Tons } \\
\text { Milled }\end{array}$} & \multirow[b]{2}{*}{$\begin{array}{c}\text { Tons } \\
\text { Concentrate }\end{array}$} & \multicolumn{5}{|c|}{ Metal Produced } & \multirow[b]{2}{*}{ Employee } \\
\hline & & & Tons Zinc & Tons Lead & $\begin{array}{l}\text { Tons } \\
\text { Coppera }\end{array}$ & $\begin{array}{c}\text { Ounces } \\
\text { Gold }\end{array}$ & Ounces Silver & \\
\hline 1989 & 264,600 & - - & 187,007 & 9,585 & -- & 23,530 & $5,166,591$ & 235 \\
\hline 1990 & 382,574 & -- & 37,000 & 16,728 & -- & 38,103 & $7,636,501$ & 265 \\
\hline 1991 & 380,000 & -- & 41,850 & 16,900 & -- & 37,000 & $7,600,000$ & 238 \\
\hline 1992 & 365,000 & 113,827 & 40,500 & 16,500 & -- & 32,400 & $7,100,000$ & 217 \\
\hline $1993^{b}$ & 77,780 & -- & 9,500 & 3,515 & -- & 7,350 & $1,721,878$ & 217 \\
\hline $1994^{c}$ & -- & -- & -- & -- & -- & -- & - - & - - \\
\hline $1995^{c}$ & -- & -- & -- & -- & -- & -- & -- & -- \\
\hline $1996^{b}$ & 135,000 & 43,000 & 9,100 & 4,200 & 193 & 7,480 & $2,476,000$ & 265 \\
\hline 1997 & 493,000 & -- & 46,000 & 19,000 & 1,300 & 56,000 & $9,700,000$ & 275 \\
\hline 1998 & 540,000 & -- & 58,900 & 22,700 & 1,300 & 60,572 & $9,500,000$ & 275 \\
\hline 1999 & 578,358 & -- & 68,527 & 25,503 & 1,400 & 80,060 & $10,261,835$ & 275 \\
\hline 2000 & 619,438 & -- & 84,082 & 31,677 & 1,400 & 128,709 & $12,424,093$ & 275 \\
\hline 2001 & 658,000 & -- & 63,903 & 22,385 & 1,400 & 87,583 & $10,900,000$ & 275 \\
\hline 2002 & 733,507 & 217,200 & 80,306 & 27,582 & 1,600 & 102,694 & $10,913,183$ & 262 \\
\hline 2003 & 781,200 & -- & 76,200 & 24,800 & -- & 99,000 & $11,707,000$ & 295 \\
\hline 2004 & 805,789 & -- & 69,115 & 21,826 & -- & 86,000 & $9,707,000$ & 265 \\
\hline 2005 & 717,600 & -- & 58,350 & 18,600 & -- & 72,800 & $9,700,000$ & $265^{d}$ \\
\hline 2006 & 732,176 & -- & 59,429 & 20,992 & -- & 62,935 & $8,865,818$ & $245^{e}$ \\
\hline 2007 & 732,227 & -- & 62,603 & 21,029 & -- & 68,006 & $8,646,825$ & $276^{f}$ \\
\hline 2008 & 734,910 & -- & 58,224 & 18,562 & -- & 67,269 & $7,145,711$ & $336^{g}$ \\
\hline 2009 & 790,871 & -- & 70,379 & 22,253 & -- & 67,278 & $7,459,170$ & $321^{h}$ \\
\hline 2010 & 800,397 & -- & 74,496 & 25,336 & -- & 68,838 & $7,206,973$ & $343^{i}$ \\
\hline 2011 & 772,069 & -- & 66,050 & 21,055 & -- & 56,818 & $6,498,337$ & $364^{i}$ \\
\hline 2012 & 789,569 & -- & 64,249 & 21,074 & -- & 55,496 & $6,394,235$ & $386^{k}$ \\
\hline 2013 & 805,322 & -- & 57,614 & 20,114 & -- & 57,457 & $7,448,347$ & $390^{\prime}$ \\
\hline 2014 & 816,213 & -- & 59,810 & 20,151 & -- & 58,810 & $7,826,341$ & 415 \\
\hline 2015 & 814,398 & -- & 61,934 & 21,617 & -- & 60,566 & $8,452,153$ & 418 \\
\hline 2016 & 815,639 & -- & 57,729 & 20,596 & -- & 53,912 & $9,253,543$ & 414 \\
\hline 2017 & 839,589 & - - & 52,547 & 17,996 & -- & 50,854 & $8,351,882$ & 423 \\
\hline Total & $16,975,226$ & -- & $1,675,404$ & 532,276 & 8,593 & $1,647,520$ & $220,063,416$ & \\
\hline
\end{tabular}

aNo copper credits in 1989-1993 and 2003-2017.

bPartial-year production.

'No production in 1994 and 1995 due to mine closure.

dFifteen of these employees were assigned to development effort.

eFifty employees were assigned to development and reported in that section's employment.

fForty-five employees were assigned to development and reported in that section's employment. sNineteen employees were assigned to development and reported in that section's employment. 'Eighty-five employees were assigned to development and reported in that sector's employment. iSeventy-nine employees were assigned to development and reported in that sector's employment. 'Nineteen employees were assigned to development and reported in that sector's employment.

kThirty-nine employees were assigned to development and reported in that sector's employment. 'All employees were assigned to the production sector.

- - = Not reported 
In 2017 Hecla purchased a new style of float cells called Staged Flotation Reactors (SFR), to replace a bank of worn out conventional flotation cells from the original mine startup in 1989. The main difference between the SFR cells and conventional flotation cells is that the froth collection and agitation stages are separated, which reduces the air flow requirement in the circuit and results in better flotation performance. Although the cells are still being optimized to provide the most beneficial economics, preliminary results show improved metals distribution and pyrite rejection. In addition, a replacement underground truck capable of operating autonomously arrived at Greens Creek, and a study of autonomous operation during shift change is underway.

\section{CHANDALAR PLACER MINE}

Seasonal mining continued at the Chandalar placer gold mine in the southern Brooks Range near the Dalton highway (photo 24). The Chandalar mine is owned by Goldrich NyacAU Placer, LLC (GNP), a joint venture between Goldrich and project manager NyacAU to mine the various placer deposits that occur throughout Goldrich's 23,000-acre Chandalar property. Production for 2017 was 14,670 ounces of placer gold, for a net of 12,000 ounces of fine gold. The 2017 production season ran from about June 4 through September 27 , and stripping of overburden continued through October 17, 2017. Goldrich NyacAU Placer drilled 231 sonic drill holes totaling 14,271 feet in order to further define mineralized placer material. Lines of test holes were approximately 500 feet apart and drill lines were spaced roughly 250 feet apart. Prior to 2017, Goldrich completed a reverse-circulation drill program that delineated approximately 10.5 million cubic yards of mineralized material at an average grade of 0.025 ounce of gold per cubic yard containing an estimated 250,000 ounces of gold.

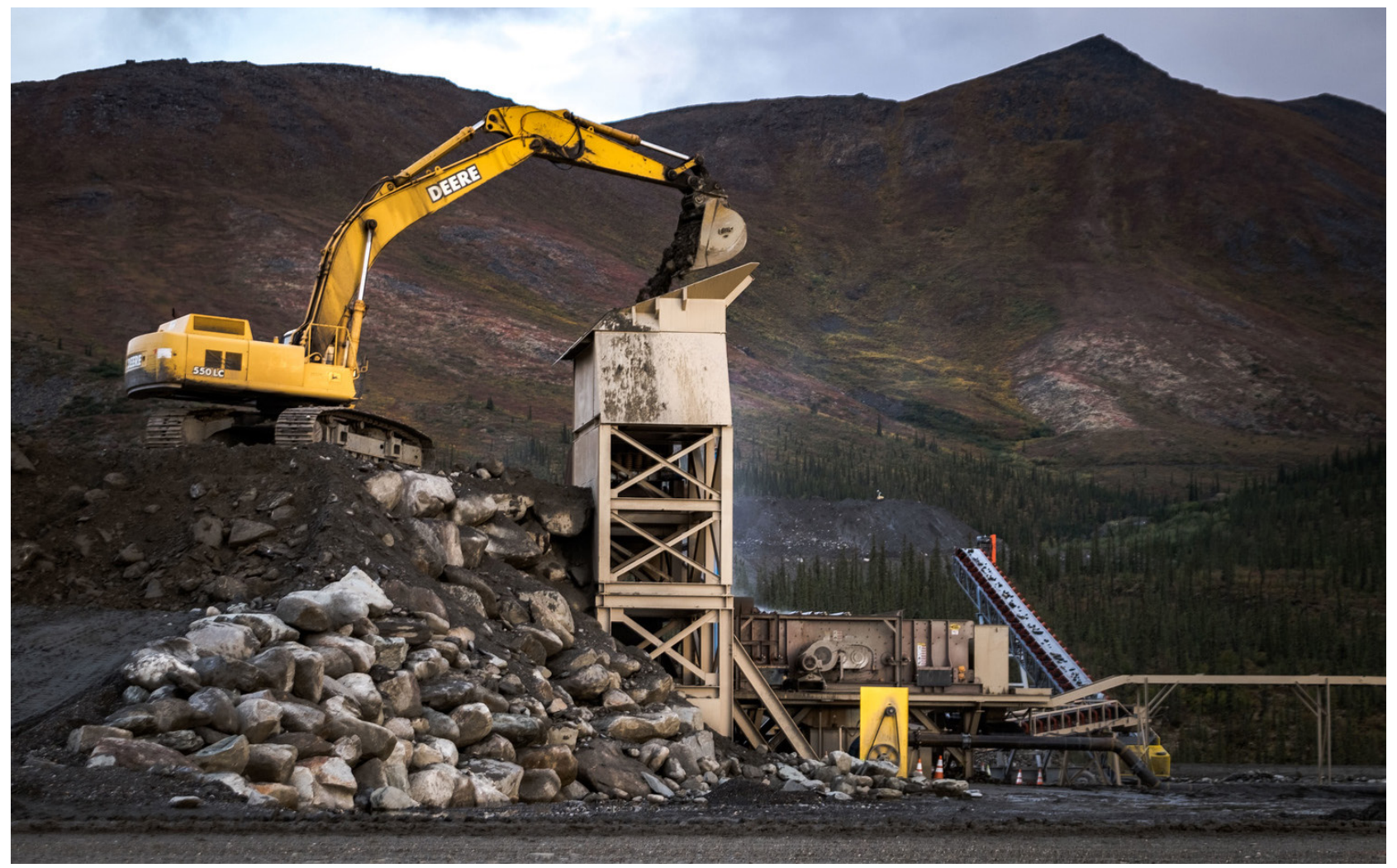

Photo 24. Goldrich NyacAU Placer, LLC's Chandalar gold mine, 190 miles north of Fairbanks, produced 14,670 ounces of placer gold from about June 4 through September 27, 2017. Photo from: Goldrich Mining Company; last accessed October 1, 2018; https://www.goldrichmining.com/images/chandalar/photo-gallery/1/GoldRich Web-0334.jpg. 


\section{DONLIN GOLD PROJECT}

Donlin is a proposed, large open-pit gold mine located in southwest Alaska, which is owned by Donlin Gold, LLC, a 50/50 partnership between Barrick Gold Corp. and NovaGold Resources Inc. The total exploration and development budget for the Donlin Gold project for 2017 was $\$ 21.7$ million. The deposit contains measured and indicated resources of approximately 39 million ounces of gold (597 million tons of ore at an average grade of 0.064 ounce of gold per ton, inclusive of proven and probable reserves of 34 million ounces of gold at an average grade of 0.061 ounce of gold per ton), and an additional approximately six million ounces of inferred resources (101 million tons at an average grade of approximately 0.059 ounce of gold per ton) (appendix D). Donlin Gold, LLC proposes to power the mine utilizing a 14-inch-diameter, 315-mile-long natural gas pipeline starting in Beluga, Alaska, passing north through the Alaska Range, and continuing to the mine site. Donlin Gold, LLC estimates the project would take 3 to 4 years to construct, with a projected mine life of approximately 27 years. As envisioned in their second updated feasibility study, Donlin Gold has the potential to become one of the largest gold-producing mines in the world, producing approximately 1.5 million ounces of gold annually in the first five years of operation and approximately 1.1 million ounces per year over its 27-year mine life.

NovaGold and Barrick made significant progress on major State permits and approvals for permitting the Donlin Gold project in 2017. In September 2017, the U.S. Army Corps of Engineers completed the cooperating agency review of the preliminary final Donlin Gold environmental impact statement, with the final document scheduled for filing in early 2018; a record of decision is expected to follow shortly thereafter.

\section{NIXON FORK MINE}

The Nixon Fork underground mine is a goldcopper skarn deposit located 32 miles northeast of
McGrath operated by Mystery Creek Resources, Inc., a wholly owned subsidiary of Titan

Resources, Ltd. The Nixon Fork mine has historically been mined as an underground cut-and-fill, shrinkage, and sub-level open stoping operation using gravity and flotation processes to recover copper concentrate, and carbon-in-leach to recover gold. The last reported resource was approximately 389,000 tons of ore containing 190,500 ounces of gold, plus 154,000 tons of tailings estimated to contain 34,700 ounces of gold (appendix D). In 2017 Mystery Creek continued work to restart the mine.

\section{DAWSON MINE}

The Dawson mine development project is located on Prince of Wales Island in southeast Alaska, about 3.5 miles from the Hollis ferry terminal. It is being developed by Sundance Mining Group LLC and Alaska Hardrock Inc. The Dawson mine is a low sulfide, high-grade, free-milling gold-silver deposit. Veins are hosted by shale and siltstone of the Descon Formation, which locally contains sills and dikes. The quartzvein system dips 28 degrees, and ore minerals include galena, chalcopyrite, sphalerite, tellurides, and free gold.

In April 2016, the first permits were issued for Phase I plans of operation. In 2017 Sundance's exploration and development operations included completing two portals, approximately 650 feet of tunnel (10.5-feet wide by 10.5-feet high), and 350 feet of drift (10.5-feet wide by 10.5-feet high) by rubber-tired mining equipment. Additionally, 140 feet of raise and scram development was completed utilizing jackleg and slusher-type mining. Current drifting and scram exploration and development are being conducted to set up future room and pillar production mining. Exploration work included geologic mapping of a 1,400-foot-long lateral drift. The Dawson mine is planned to be a small gold operation with a forecast mill throughput of about 150 tons per day. 


\section{DRILLING}

Seventeen companies publicly reported significant drilling programs in Alaska in 2017 across all sectors

(table 20). Total 2017 drilling was 1,016,731 feet, up 58 percent to a level not seen since 2012 (table 21). Development drilling totaled 309,921 feet, and production drilling totaled 66,900 feet. Increased funding for exploration led to new and larger drilling programs in 2017. In Alaska drilling programs were reported for 21 individual metal exploration projects, five more projects than in 2016. Exploration drilling totaled 639,911 feet in 2017, 49 percent more feet than drilled in 2016 (photo 25). About 347,191 feet or 54 percent of exploration drilling was conducted at mine sites to increase reserves and extend mine life, up from 39 percent in 2016. Globally, the number of projects reporting drill results rose to 567 projects. $^{8}$

Drilling footage was primarily compiled from questionnaires, public company reports, and online information, and represents a minimum amount for 2017. Placer exploration drilling in 2017 was not compiled, and development and production drilling is also likely underreported. Blast-hole drilling during production at Alaska’s large lode mines was not tracked.

Table 20. Companies publicly reporting significant drilling programs in Alaska in 2017.

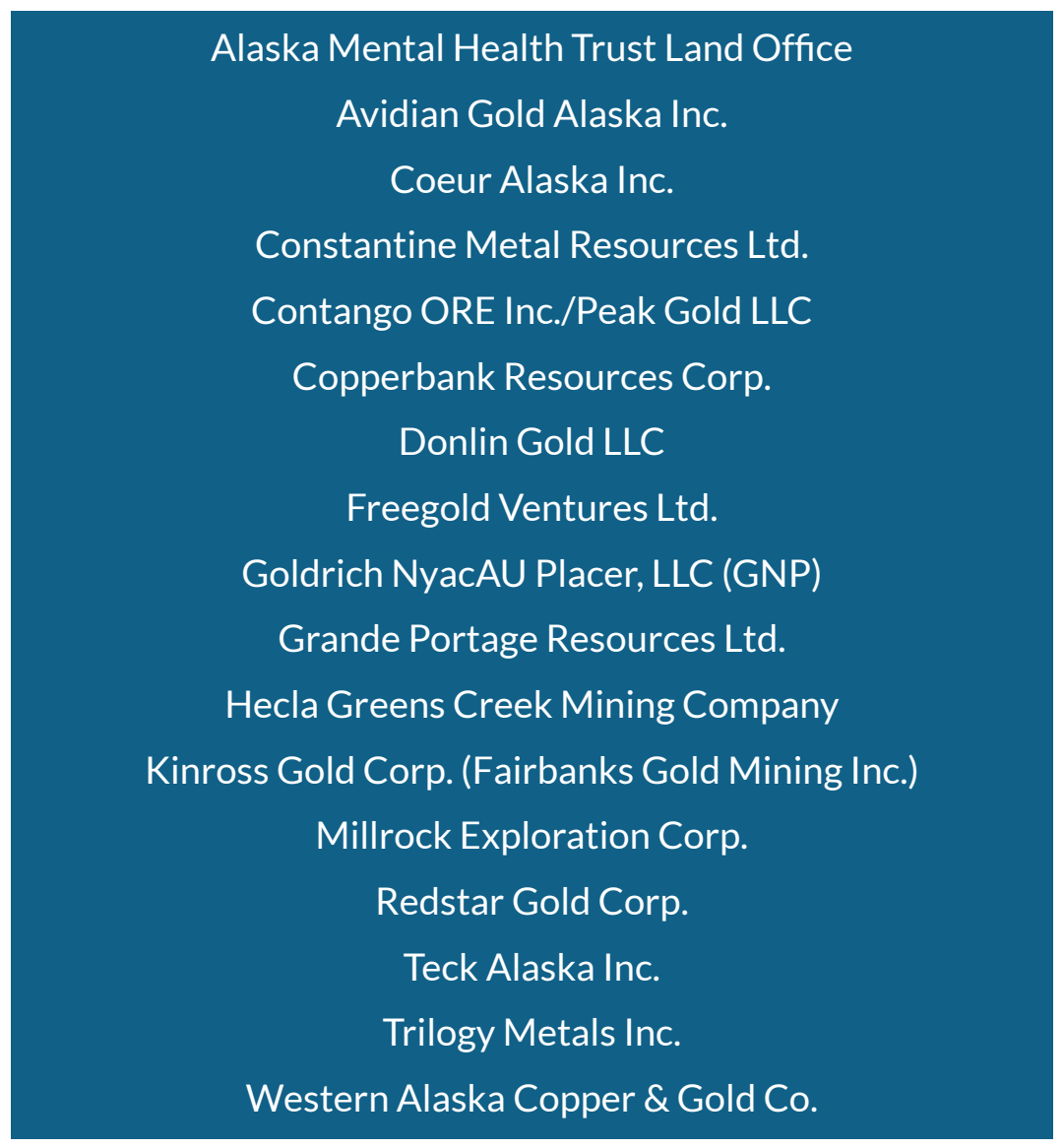




\section{ACKNOWLEDGMENTS}

The authors thank the companies, agencies, and individuals who responded to emails or phone calls and provided information about their activities and operations. Without their voluntary and timely information, this report would not be possible. We gratefully acknowledge Karen Matthias (Council of Alaska Producers) for her assistance in contacting operators. In addition to operational information, members of the public and industry provided photographs and images used in this report. These contributions are greatly appreciated. The authors specifically acknowledge Robert $\mathrm{T}$. Boyd (Endurance Gold Corporation), Andy West and Erin Workman (Trilogy Metals Inc.), Robert Fithian (Sundance Mining Group LLC), Tom Setterfield (Avidian Gold Alaska Inc.), Richard Graham (Rhyolite Resources Ltd), Karsten Eden (Trust Land Office), and Brigitte Dejou (CopperBank Resources Corp.) for providing photos.

Table 21. Drilling footage reported or estimated in Alaska, 1982-2017.

\begin{tabular}{rcccccccc} 
Year & $\begin{array}{c}\text { Placer } \\
\text { Exploration }\end{array}$ & $\begin{array}{c}\text { Placer } \\
\text { Thawing }\end{array}$ & $\begin{array}{c}\text { Total } \\
\text { Placer }\end{array}$ & Total Coal & $\begin{array}{c}\text { Hardrock } \\
\text { Core }^{\mathrm{a}}\end{array}$ & $\begin{array}{c}\text { Hardrock } \\
\text { Rotary }^{\mathrm{a}}\end{array}$ & $\begin{array}{c}\text { Total } \\
\text { Hardrock }\end{array}$ & $\begin{array}{c}\text { Total Feet } \\
\text { Drilled }\end{array}$ \\
\hline 1994 & 21,000 & -- & 21,000 & 8,168 & 347,018 & 91,692 & 438,710 & 467,878 \\
\hline 1995 & 27,570 & -- & 27,570 & -- & 363,690 & 51,795 & 415,485 & 443,055 \\
\hline 1996 & 61,780 & -- & 61,780 & 8,500 & 524,330 & 134,527 & 658,857 & 729,137 \\
\hline 1997 & 38,980 & -- & 38,980 & 13,998 & 523,676 & 180,834 & 704,510 & 757,488 \\
\hline 1998 & 33,250 & -- & 33,250 & 2,300 & 505,408 & 45,670 & 551,078 & 586,628 \\
\hline 1999 & 6,727 & -- & 6,727 & -- & 369,863 & 78,934 & 448,797 & 455,524 \\
\hline 2000 & 15,480 & -- & 15,480 & -- & 418,630 & 127,638 & 546,268 & 561,748 \\
\hline 2001 & 1,100 & -- & 1,100 & 36,151 & 240,318 & 75,750 & 316,068 & 353,319 \\
\hline 2002 & 1,250 & -- & 1,250 & -- & 385,290 & 103,612 & 488,902 & 490,152 \\
\hline 2003 & 10,108 & -- & 10,108 & 2,000 & 270,456 & 100,178 & 370,634 & 382,742 \\
\hline 2004 & 107,526 & -- & 107,526 & -- & 415,628 & 36,024 & 451,652 & 559,178 \\
\hline 2005 & 3,360 & -- & 3,360 & -- & 592,497 & 41,780 & 634,277 & 637,637 \\
\hline 2006 & 8,759 & -- & 8,759 & 7,500 & 765,363 & 54,173 & 819,536 & 835,795 \\
\hline 2007 & 19,575 & -- & 19,575 & 50,539 & 830,478 & 268,112 & $1,098,590$ & $1,168,704$ \\
\hline 2008 & 1,216 & -- & 1,216 & 26,869 & 874,634 & 250,278 & $1,124,912$ & $1,152,997$ \\
\hline 2009 & 1,244 & -- & 1,244 & $W$ & 403,275 & 260,059 & 663,334 & 664,578 \\
\hline 2010 & 10,427 & -- & 10,427 & 11,601 & 688,911 & 216,768 & 905,679 & 927,707 \\
\hline 2011 & 3,150 & -- & 3,150 & $W$ & 883,272 & 175,181 & $1,058,453$ & $1,061,603$ \\
\hline 2012 & 13,282 & -- & 13,282 & 7,704 & $1,082,439$ & 14,182 & $1,096,621$ & $1,117,607$ \\
\hline 2013 & 17,986 & -- & 17,986 & $W$ & 933,194 & 17,800 & 950,994 & 968,980 \\
\hline 2014 & 7,227 & -- & 7,227 & $W$ & 487,106 & 9,736 & 496,842 & 504,069 \\
\hline 2015 & -- & -- & -- & $W$ & 923,324 & 12,795 & 937,769 & 937,769 \\
\hline 2016 & -- & -- & -- & -- & 644,512 & $W$ & 644,512 & 644,512 \\
\hline 2017 & -- & -- & -- & $W$ & $1,016,731$ & $W$ & $1,016,731$ & $1,016,731$ \\
\hline & & & & & & & & \\
\hline
\end{tabular}

${ }^{a}$ Core and rotary drilling not differentiated prior to 1987.

- - = Not reported

$W=$ withheld for confidentiality; included in hardrock rotary or core. 
Where appropriate, contributors have been acknowledged in the text.

The production of this publication depends upon the collaboration of many agencies and organizations. Listed here are staff from the major agencies and organizations who provided mining-related information. Karinne Wiebold (Department of Labor and Workforce Development) provided updated mining employment and wage information. Joseph Caissie (Alaska Department of Revenue), Yulia Ellsworth (Alaska Industrial Development and Export Authority), Kyle Moselle [Department of Natural Resources (DNR)/Office of Project Management and Permitting], Cristin Cowles-Brunton (DNR/Support Services Division), and Wendi Planty (Denali Borough) provided government revenue data. Jeff Jasper (DNR/Information Resources Management) and Julie McLane (U.S. Bureau of Land Management) provided claim information. Zoya
Ponomareva (DMLW) provided information on the industrial minerals sector, as well as Edward Klimasauskas and Joseph Galluzzi (U.S. Bureau of Land Management) and Steve Hohensee (U.S. Forest Service). Deborah Morgan (Alaska Governor's Office/Office of International Trade) provided commodity export information. Jamey Jones (U.S. Geological Survey), Steve Buckley (DMLW), John Hoppe (U.S. Bureau of Land Management), and Evan Twelker, Kurt Johnson, Abraham Emond, and Gina Graham (DGGS) provided information on government activities in Alaska in 2017. Jennifer Athey and Melanie Werdon (DGGS) compiled the data and prepared the body of the text, tables, and appendices; Evan Twelker (DGGS) edited and reviewed the text and tables and updated the graphic illustrations. The booklet's design, layout, and cover are by Kristen Janssen (DGGS); Ken Papp and Steve Masterman (DGGS) edited the final version.

Photo 25. View looking north from Pyramid project drill site 17PYR033 on the Alaska Peninsula, with an old access road built in the 1970s in the background. CopperBank Resources Corp. drilled 12,106 feet in 2017 to update Pyramid's resource estimate and plan future drill programs. Photo courtesy of Brigitte Dejou, CopperBank Resources Corp.

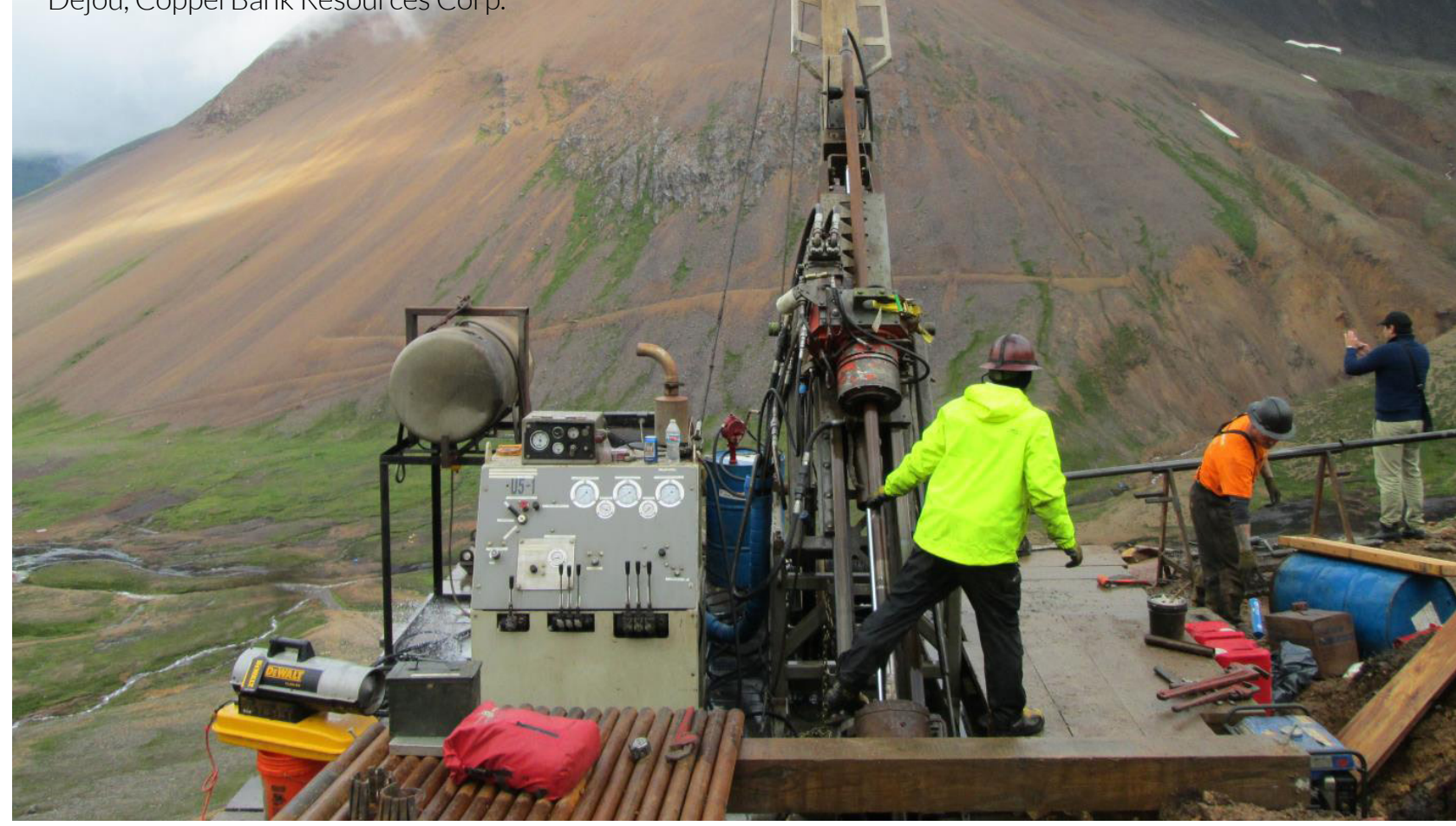




\section{APPENDICES}

\section{APPENDIX A}

\section{Resources Related to the Minerals Industry in Alaska}

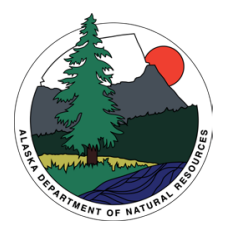

\section{DEPARTMENT OF NATURAL RESOURCES}

Recording Fees - http://dnr.alaska.gov/ssd/recoff/fees RO.cfm

Public Information Center - http://dnr.alaska.gov/commis/pic/

State Uniform Commercial Code (UCC) Documents Search - http://dnr.alaska.gov/ssd/recoff/searchUCC.cfm

\section{Division of Mining, Land \& Water}

Mining Applications and Forms - http://dnr.alaska.gov/m/w/forms/

Fact Sheets - http://dnr.alaska.gov/m/w/factsht/

Annual Placer Mining Application (APMA) - http://dnr.alaska.gov/mlw/mining/placer.cfm

Annual Rental - http://dnr.alaska.gov/mlw/factsht/mine fs/annualre.pdf

Leasing State Land - http://dnr.alaska.gov/m/w/factsht/land fs/lease land.pdf

Land Lease \& Contract Payment Information - http://dnr.alaska.gov/mlw/factsht/land fs/lease contract payment info.pdf

Production Royalty - http://dnr.alaska.gov/mlw/factsht/mine fs/producti.pdf

DNR Production Royalty Form - http://dnr.alaska.gov/m/w/forms/mining/royalty fm.pdf

Exploration Incentive Credit Program - http://dnr.alaska.gov/m/w/factsht/mine fs/explore.pdf

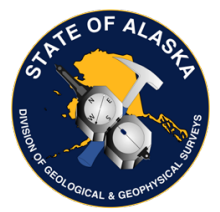

Division of Geological \& Geophysical Surveys

Publications On-Line - http://dggs.alaska.gov/pubs/

Interactive Maps - http://maps.dggs.alaska.gov/

Geologic Maps of Alaska: Online Map Search Tool - http://maps.dggs.alaska.gov/mapindex/

Unpublished Geology-Related Data (Alaska Geologic Data Index) - http://maps.dggs.alaska.gov/agdi/

Geologic Materials Center - http://dggs.alaska.gov/gmc/

Alaska Geochemistry Web Map - http://maps.dggs.alaska.gov/geochem/

Alaska's Minerals Data \& Information Rescue in Alaska (MDIRA) Project Websites

MDIRA Portal Home Page - http://akgeology.info/

Alaska Mining Claims Mapper - http://akmining.info/

Land Records Web Application - http://dnr.alaska.gov/Landrecords/

State Recorder's Office Search - http://dnr.alaska.gov/ssd/recoff/searchRO.cfm

Alaska Resource Data Files - http://ardf.wr.usgs.gov/

USGS Alaska Geochemical Database, Version 2.0 (NURE, RASS, PLUTO...) - https://pubs.er.usgs.gov/publication/ds759

Guide to Alaska Geologic and Mineral Information - http://doi.org/10.14509/3318

Alaska State Geo-Spatial Data Clearinghouse - http://www.asgdc.state.ak.us/

\section{ALASKA \\ COMARTENT COMMUNITY AND ECONOMIĆ ANDEELOPMENT}

\section{DEPARTMENT OF COMMERCE, COMMUNITY, AND ECONOMIC DEVELOPMENT}

Minerals Information - https://www.commerce.alaska.gov/web/ded/dev/mineralsdevelopment Community and Regional Information - https://www.commerce.alaska.gov/web/dcra/ResearchAnalysis Alaska Industrial Development and Export Authority (AIDEA) - http://www.aidea.org AIDEA Supports Mining - http://www.aidea.org/Programs/ProjectDevelopment/33YearsofMiningSupport.aspx

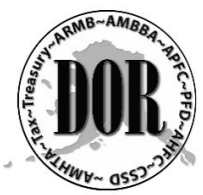

\section{DEPARTMENT OF REVENUE}

Mining License Tax - http://www.tax.alaska.gov/programs/programs/index.aspx?60610

Motor Fuel Tax Claim for Refund - http://www.tax.alaska.gov//programs/programs/forms/index.aspx?60210

Alaska Motor Fuel Tax Instructions - http://www.tax.alaska.gov/programs/documentviewer/viewer.aspx?5086f 


\section{APPENDIX B}

\section{Primary metals production in Alaska, 1880-2017}

\begin{tabular}{|c|c|c|c|c|c|c|c|c|c|c|}
\hline \multirow{2}{*}{ Year } & \multicolumn{2}{|c|}{ Gold $^{b}$} & \multicolumn{2}{|c|}{ Silver } & \multicolumn{2}{|c|}{ Mercury } & \multicolumn{2}{|c|}{ Antimony } & \multicolumn{2}{|c|}{ Tin } \\
\hline & (oz) & $(\mathrm{m} \$)$ & (oz) & $(\mathrm{t} \$)$ & (flask ${ }^{c}$ ) & $(t \$)$ & (lb) & $(t \$)$ & (lb) & (t\$) \\
\hline 1880-99 & $1,153,889$ & $\$ 23.9$ & 496,101 & $\$ 329.0$ & $-\cdot$ & -. & $-\cdot$ & $-\cdot$ & -. & -. \\
\hline 1900-09 & $6,673,173$ & 137.9 & $1,324,580$ & 779.5 & -- & $-\cdot$ & -- & $-\cdot$ & 304,000 & $\$ 112.2$ \\
\hline 1910-19 & $7,209,094$ & 149.0 & $7,058,235$ & $5,107.5$ & -- & $-\cdot$ & $2,760,000$ & w & $1,640,000$ & 805.9 \\
\hline $1920-29$ & $3,373,336$ & 69.8 & $6,407,375$ & $5,160.8$ & 117 & $\$ 7.6$ & W & w & 317,800 & 163.9 \\
\hline 1930-39 & $5,345,205$ & 150.8 & $3,250,173$ & $1,889.8$ & 31 & 2.3 & $1,616,000$ & $\$ 228.3$ & $1,024,400$ & 502.1 \\
\hline $1940-49$ & $3,137,447$ & 109.8 & 794,842 & 577.0 & 3,094 & 724.3 & $2,062,080$ & 311.1 & 319,200 & 230.3 \\
\hline 1950-59 & $2,297,827$ & 80.6 & 321,669 & 292.9 & 18,185 & $4,370.0$ & $2,663,520$ & $3,697.6$ & $1,144,000$ & $1,310.5$ \\
\hline $1960-69$ & 751,870 & 26.6 & 59,300 & 70.7 & 13,996 & $3,098.0$ & 228,800 & 267.8 & -- & $-\cdot$ \\
\hline $1970-79$ & 324,906 & 55.8 & 54,700 & 250.5 & 4,040 & $1,694.0$ & $1,473,000$ & $1,714.0$ & 166,000 & 949.0 \\
\hline 1980 & 75,000 & 32.0 & 7,500 & 111.0 & $-\cdot$ & -- & $-\cdot$ & -- & 120,000 & 984.0 \\
\hline 1981 & 134,200 & 55.2 & 13,420 & 111.3 & W & W & -- & $-\cdot$ & 106,000 & 700.0 \\
\hline 1982 & 175,000 & 69.9 & 22,000 & 198.0 & -- & -- & -- & -- & 198,000 & $1,365.0$ \\
\hline 1983 & 169,000 & 67.6 & 33,200 & 332.0 & -- & -- & 22,400 & 45.0 & 215,000 & $1,100.0$ \\
\hline 1984 & 175,000 & 62.1 & 20,000 & 159.0 & 5 & 1.5 & 135,000 & 225.8 & 225,000 & 400.0 \\
\hline 1985 & 190,000 & 61.2 & 28,500 & 171.0 & 27 & 10.0 & 65,000 & 98.0 & 300,000 & 650.0 \\
\hline 1986 & 160,000 & 60.8 & 24,000 & 134.4 & 12 & 2.8 & 45,000 & 67.5 & 340,000 & 890.0 \\
\hline 1987 & 229,707 & 104.5 & 54,300 & 391.0 & -- & -- & $-\cdot$ & -- & 288,000 & 460.0 \\
\hline 1988 & 265,500 & 112.8 & 47,790 & 282.0 & W & W & $-\cdot$ & $-\cdot$ & 300,000 & 950.0 \\
\hline 1989 & 284,617 & 108.7 & $5,211,591$ & $27,300.0$ & -. & -. & -. & -. & 194,000 & 672.0 \\
\hline 1990 & 231,700 & 89.2 & $10,135,000$ & $50,675.0$ & $-\cdot$ &.- & $-\cdot$ & $-\cdot$ & 57,000 & 200.0 \\
\hline 1991 & 243,900 & 88.3 & $9,076,854$ & $39,110.0$ & -- & $-\cdot$ & $-\cdot$ & $-\cdot$ & 6,800 & 22.1 \\
\hline 1992 & 262,530 & 88.5 & $9,115,755$ & $34,913.0$ & $-\cdot$ & $-\cdot$ & -- & $-\cdot$ & 1,500 & 5.9 \\
\hline 1993 & 191,265 & 68.6 & $5,658,958$ & $24,333.0$ & -- & -- & -- & -- & 21,000 & 50.6 \\
\hline 1994 & 182,100 & 70.3 & $1,968,000$ & $10,391.0$ &.- & $-\cdot$ & -- & -- & -. & -- \\
\hline 1995 & 141,882 & 56.0 & $1,225,730$ & 6,655.0 & -- & -- & -- & -- & -- & $-\cdot$ \\
\hline 1996 & 161,565 & 62.6 & $3,676,000$ & $19,078.0$ & $-\cdot$ & $-\cdot$ & $-\cdot$ & $-\cdot$ & $-\cdot$ & -.- \\
\hline 1997 & 590,516 & 207.3 & $14,401,165$ & $70,710.0$ & $-\cdot$ & $-\cdot$ & -- & $-\cdot$ & $-\cdot$ & -- \\
\hline 1998 & 594,191 & 174.6 & $14,856,000$ & $82,154.0$ & -- & -- & -- & -- & -- & -- \\
\hline 1999 & 517,890 & 144.3 & $16,467,000$ & $85,628.0$ & -- & -- & -- & $-\cdot$ & $-\cdot$ & $-\cdot$ \\
\hline 2000 & 551,982 & 154.1 & $18,226,615$ & $90,404.0$ & -- & -- & -- & $-\cdot$ & $-\cdot$ & -- \\
\hline 2001 & 550,644 & 149.3 & $16,798,000$ & $73,408.0$ &.- & $-\cdot$ & -- & $-\cdot$ & $-\cdot$ &.- \\
\hline 2002 & 562,094 & 174.3 & $17,858,183$ & $82,326.0$ & -- & $-\cdot$ & -- & $-\cdot$ & $-\cdot$ & $-\cdot$ \\
\hline 2003 & 528,191 & 191.9 & $18,589,100$ & $95,300.0$ & -- & -- & -- & -- & -- & $-\cdot$ \\
\hline 2004 & 456,508 & 192.3 & $16,947,270$ & $113,056.9$ & -- & $-\cdot$ & $-\cdot$ & -- & -- & -- \\
\hline 2005 & 427,031 & 189.9 & $11,670,000$ & $85,382.0$ & $-\cdot$ & $-\cdot$ & $-\cdot$ & -- &.- & -. \\
\hline 2006 & 570,129 & 344.1 & $16,489,394$ & $190,415.9$ & -- & $-\cdot$ & $-\cdot$ & $-\cdot$ & $-\cdot$ & $-\cdot$ \\
\hline 2007 & 726,933 & 511.1 & $20,203,985$ & $270,402.1$ & $-\cdot$ & $-\cdot$ & $-\cdot$ & $-\cdot$ & $-\cdot$ & $-\cdot$ \\
\hline 2008 & 800,752 & 698.2 & $14,643,735$ & $219,496.4$ & -- & $-\cdot$ & $-\cdot$ & $-\cdot$ & -- & $-\cdot$ \\
\hline 2009 & 780,657 & 759.1 & $15,617,436$ & $229,159.3$ & $-\cdot$ & $-\cdot$ & $-\cdot$ & $-\cdot$ & $-\cdot$ & $-\cdot$ \\
\hline 2010 & 914,462 & $1,119.8$ & $13,991,297$ & $282,523.5$ & -. & -. & -. & -. & -. & $-\cdot$ \\
\hline 2011 & 848,945 & $1,334.1$ & $11,683,967$ & $410,340.9$ & $-\cdot$ & -. & $-\cdot$ & $-\cdot$ & $-\cdot$ & $-\cdot$ \\
\hline 2012 & 921,240 & $1,537.5$ & $12,313,877$ & $383,573.6$ & $-\cdot$ & $-\cdot$ & $-\cdot$ & $-\cdot$ & $-\cdot$ & $-\cdot$ \\
\hline 2013 & $1,022,987$ & $1,551.9$ & $13,453,367$ & $320,121.0$ & -- & $-\cdot$ & -- & $-\cdot$ & $-\cdot$ & $-\cdot$ \\
\hline 2014 & 948,547 & $1,201.2$ & $15,388,901$ & $304,392.5$ & -- & $-\cdot$ & -- & -- & -.- & -.- \\
\hline 2015 & 941,394 & $1,013.9$ & $15,147,249$ & $237,508.9$ & -. & -. &.- & -. & -. & -- \\
\hline 2016 & 909,242 & $1,119.3$ & $16,621,035$ & $246,109.8$ & -- & -. & -- &.- & $-\cdot$ & $-\cdot$ \\
\hline 2017 & 859,631 & $1,064.0$ & $16,085,142$ & $274,163.2$ & -. & -- & -- & $-\cdot$ & $-\cdot$ & -- \\
\hline Othere & -- & -- & -- & -- & 1,438 & $-\cdot$ & $-\cdot$ & -- & $-\cdot$ & $-\cdot$ \\
\hline Total & $48,563,680$ & $\$ 15,894.7$ & $393,538,291$ & $\$ 4,375,378.5$ & 40,945 & $\$ 9,910.5$ & $11,070,800$ & $\$ 6,655.1$ & $7,287,700$ & $\$ 12,523.5$ \\
\hline
\end{tabular}

$\mathrm{t} \$=$ thousands of dollars $\quad \mathrm{m} \$=$ millions of dollars

- - = Not reported W $\quad W$ withheld

${ }^{a}$ From published and unpublished State and Federal documents. Where State and Federal figures differ significantly, State figures are used. Please refer to previous editions of this appendix for year-to-year production information for years 1900 to 1979.

${ }^{\mathrm{b}} \mathrm{Gold}$ production adjusted to be more consistent with mining district production totals.

c76-lb flask.

${ }^{\mathrm{d} C}$ Crude platinum; total production of refined metal is about $575,000 \mathrm{oz}$

eNot traceable by year 


\section{APPENDIX B, Continued Primary metals production in Alaska, $1880-2017^{a}$}

\begin{tabular}{|c|c|c|c|c|c|c|c|c|c|c|}
\hline \multirow{2}{*}{ Year } & \multicolumn{2}{|c|}{ Lead } & \multicolumn{2}{|c|}{ Zinc } & \multicolumn{2}{|c|}{ Platinum $^{d}$} & \multicolumn{2}{|c|}{ Copper } & \multicolumn{2}{|c|}{ Chromium } \\
\hline & (tons) & $(t \$)$ & (tons) & $(t \$)$ & (oz) & $(\mathrm{t} \$)$ & (lb) & $(m \$)$ & (tons) & $(t \$)$ \\
\hline 1880-99 & 250 & 17.0 & -- & $-\cdot$ & -- & $-\cdot$ & -- & -- & - & -- \\
\hline 1900-09 & 369 & 32.8 & -- & -- & -- & -- & $29,549,486$ & 4.8 & -- & -- \\
\hline 1910-19 & 3,565 & 470.2 & -- & -- & 914 & $\$ 116.5$ & $515,253,817$ & 109.9 & 2,200 & W \\
\hline 1920-29 & 7,961 & $1,084.1$ & -- & -- & 5,750 & 484.9 & $643,576,929$ & 93.3 & -- & $-\cdot$ \\
\hline 1930-39 & 10,791 & 914.3 & -- & -- & 102,615 & $5,427.1$ & $184,522,000$ & 19.5 & -- & -- \\
\hline 1940-49 & 3,096 & 405.2 & 678 & 0.5 & 225,285 & $12,623.3$ & 433,700 & 0.2 & 7,409 & $\$ 250.9$ \\
\hline 1950-59 & 177 & 38.6 & -- & -- & 107,927 & $9,403.9$ & 106,000 & 0.1 & 21,442 & $1,975.8$ \\
\hline $1960-69$ & 40 & 9.9 & -- & -- & 111,556 & $13,618.5$ & 352,000 & 0.1 & -- & -- \\
\hline 1970-79 & 20 & 8.0 & -- & -- & 41,604 & $6,826.0$ & -- & -- & 8,000 & $1,200.0$ \\
\hline 1980 & 31 & 29.0 & -- & -- & -- & -- & -- & -- & -- & -- \\
\hline 1981 & -- & -- & -- & -- & 900 & 200.0 & -- & -- & -- & -- \\
\hline 1982 & -- & -- & -- & -- & W & W & -- & -- & $-\cdot$ & -- \\
\hline 1983 & -- & -- & -- & -. & W & W & -- & -- & -- & -- \\
\hline 1984 & -- & -- & -- & -- & W & W & -- & -- & -- & -- \\
\hline 1985 & -- & -- & -- & -- & -- & -. & -. & -- & -- & -- \\
\hline 1986 & -- & -- & -- & -- & W & W & -- & -- & -- & -- \\
\hline 1987 & -- & -- & -- & -- & W & W & -- & -- & -- & -- \\
\hline 1988 & -- & -- & -- & -- & 25 & 13.8 & -- & -- & -- & -- \\
\hline 1989 & 9,585 & $7,700.0$ & 19,843 & $29,400.0$ & -- & -- & -- & -- & -- & -- \\
\hline 1990 & 44,220 & $30,954.0$ & 181,200 & $253,680.0$ & -- & -- & -. & -- & $-\cdot$ & -- \\
\hline 1991 & 69,591 & $33,403.7$ & 278,221 & $278,221.0$ & 15 & 5.3 & -- & -- & -- & -- \\
\hline 1992 & 68,664 & $31,585.0$ & 274,507 & $301,957.7$ & -- & -- & -- & -- & -- & -- \\
\hline 1993 & 38,221 & $13,759.6$ & 268,769 & $236,516.7$ & 3 & 1.2 & -- & -- & -- & -- \\
\hline 1994 & 36,447 & $25,512.9$ & 329,003 & $296,102.7$ & 5 & 2.1 & -- & -- & -- & -- \\
\hline 1995 & 58,098 & $34,428.6$ & 359,950 & $345,552.0$ & 1 & 0.4 & -- & -- & - & -- \\
\hline 1996 & 70,086 & $52,284.0$ & 366,780 & $361,646.0$ & 2 & 0.8 & 780,000 & 0.8 & -- & -- \\
\hline 1997 & 88,560 & $49,593.0$ & 419,097 & $494,888.0$ & -- & -. & $3,440,000$ & 3.5 & $-\cdot$ & -- \\
\hline 1998 & 102,887 & $49,386.0$ & 549,348 & $505,400.0$ & -- & -- & $3,800,000$ & 2.9 & -- & -- \\
\hline 1999 & 125,208 & $57,596.0$ & 643,642 & $630,769.0$ & -- & -- & $4,200,000$ & 3.0 & -- & -- \\
\hline 2000 & 123,224 & $51,754.0$ & 669,112 & $682,494.0$ & -- & -. & $2,800,000$ & 2.3 & $-\cdot$ & -- \\
\hline 2001 & 127,385 & $56,049.0$ & 634,883 & $507,907.0$ & -- & -- & $2,800,000$ & 2.0 & $-\cdot$ & -- \\
\hline 2002 & 146,462 & $61,514.0$ & 718,103 & $502,674.0$ & -- & -- & $3,200,000$ & 2.3 & - & -- \\
\hline 2003 & 162,479 & $64,279.0$ & 714,769 & $536,348.0$ & -- & -- & -. & -- & -- & -- \\
\hline 2004 & 150,796 & $120,636.8$ & 680,015 & $651,432.2$ & -- & -- & -- & -- & -- & -- \\
\hline 2005 & 131,366 & $115,230.0$ & 684,462 & $862,108.0$ & -- & -- & -- & -- & -- & -- \\
\hline 2006 & 157,128 & $183,629.3$ & 673,967 & $2,002,971.4$ & -- & -- & -- & -- & $-\cdot$ & -- \\
\hline 2007 & 167,181 & $389,532.2$ & 696,115 & $2,048,451.6$ & -- & -- & 87,627 & 0.3 & -- & -- \\
\hline 2008 & 153,705 & $287,428.4$ & 626,135 & $1,055,220.1$ & -- & $-\cdot$ & -- & -- & -- & -- \\
\hline 2009 & 167,204 & $260,838.2$ & 712,496 & $1,068,744.0$ & -- & -- & -- & -- & -- & -- \\
\hline 2010 & 146,480 & $284,171.2$ & 667,539 & $1,212,390.3$ & -- & -- & -- & -- & -- & -- \\
\hline 2011 & 113,649 & $247,755.2$ & 696,793 & $1,379,649.2$ & 5,000 & $8,609.3$ & 1,058 & 0.0 & $-\cdot$ & -- \\
\hline 2012 & 126,234 & $234,795.2$ & 647,481 & $1,139,566.6$ & -- & -- & 14,327 & 0.0 & -- & -- \\
\hline 2013 & 126,707 & $245,811.6$ & 665,318 & $1,157,653.3$ & $-\cdot$ & $-\cdot$ & 77,240 & 0.3 & $-\cdot$ & -- \\
\hline 2014 & 155,183 & $294,847.2$ & 716,781 & $1,404,890.4$ & -- & -- & -- & -- & -- & -- \\
\hline 2015 & 151,247 & $245,126.5$ & 686,938 & $1,204,315.0$ & -- & -- & -- & -- & -- & -- \\
\hline 2016 & 155,409 & $241,931.4$ & 700,376 & $1,250,186.4$ & -- & -- & -- & -- & -- & -- \\
\hline 2017 & 140,683 & $288,118.8$ & 649,889 & $1,639,020.1$ & -- & -- & -- & -- & -- & -- \\
\hline Other & -- & -. & -- & -- & 71,946 & $17,091.9$ & -- & -- & -- & -- \\
\hline Total & $3,340,389$ & $\$ 4,062,659.8$ & $15,932,210$ & $\$ 24,040,155.2$ & 673,548 & $\$ 57,333.1$ & 1,394,994,184 & $\$ 245.3$ & 39,051 & $\$ 3,426.7$ \\
\hline
\end{tabular}

$t \$=$ thousands of dollars

$m \$=$ millions of dollars

- - = Not reported

$W=$ withheld

aFrom published and unpublished State and Federal documents. Where State and Federal figures differ significantly, State figures are used. Please refer to previous editions of this appendix for year-to-year production information for years 1900 to 1979.

${ }^{b}$ Gold production adjusted to be more consistent with mining district production totals.

c76-Ib flask.

${ }^{d}$ Crude platinum; total production of refined metal is about 575,000 oz.

eNot traceable by year 


\section{APPENDIX C}

\section{Production of industrial minerals, coal, and other commodities in Alaska, 1880-2017a,b}

\begin{tabular}{|c|c|c|c|c|c|c|c|c|c|}
\hline \multirow[b]{2}{*}{ Year } & \multicolumn{2}{|c|}{ Coal } & \multicolumn{2}{|c|}{ Sand and Gravel ${ }^{\mathrm{c}}$} & \multicolumn{2}{|c|}{ Rock $^{d}$} & \multicolumn{2}{|c|}{ Barite } & \multirow{2}{*}{$\begin{array}{c}\text { Othere } \\
\$\end{array}$} \\
\hline & $\begin{array}{c}\text { short } \\
\text { tons }\end{array}$ & $m \$$ & short tons & $m \$$ & $\begin{array}{l}\text { short } \\
\text { tones }\end{array}$ & $m \$$ & $\begin{array}{c}\text { short } \\
\text { tons }\end{array}$ & $t \$$ & \\
\hline 1880-99 & 19,429 & $\$ 0.1$ & -- & -- & 7,510 & -- & -- & -- & -- \\
\hline 1900-09 & 33,214 & 0.2 & -- & -- & 15,318 & -- & $-\cdot$ & -- & $\$ 246,403$ \\
\hline 1910-19 & 210,806 & 1.2 & -- & -- & 50,014 & -- & -- & -- & $2,014,788$ \\
\hline 1920-29 & 937,860 & 5.2 & -- & -- & 494,417 & -- & -- & -- & $2,523,754$ \\
\hline 1930-39 & $1,222,797$ & 5.5 & 42,332 & $\$ 0.0$ & 689,676 & -- & $-\cdot$ & -- & 899,767 \\
\hline 1940-49 & $3,189,026$ & 20.2 & $1,758,504$ & 0.7 & 286,341 & -- & $-\cdot$ & -- & $27,124,158$ \\
\hline 1950-59 & $6,632,641$ & 59.7 & $65,804,686$ & 55.1 & $1,843,560$ & -- & -- & $-\cdot$ & $25,443,427$ \\
\hline 1960-69 & $7,849,000$ & 58.8 & $163,315,000$ & 176.7 & $2,034,000$ & -- & 225,000 & $\$ 1,200.0$ & $34,143,000$ \\
\hline 1970-79 & $7,405,000$ & 89.0 & $489,522,000$ & $1,004.9$ & $47,930,000$ & -- & 502,000 & $8,217.0$ & $77,501,000$ \\
\hline 1980 & 800,000 & 16.0 & $40,000,000$ & 86.0 & $3,700,000$ & -- & 50,000 & $2,000.0$ & 97,500 \\
\hline 1981 & 800,000 & 17.6 & $46,000,000$ & 88.2 & $4,200,000$ & -- & -- & -. & 256,000 \\
\hline 1982 & 830,000 & 18.0 & $45,000,000$ & 91.0 & $3,400,000$ & -- & -- & -- & 150,000 \\
\hline 1983 & 830,000 & 18.0 & $50,000,000$ & 105.0 & $5,270,000$ & -- & -- & -- & 242,000 \\
\hline 1984 & 849,161 & 23.8 & $27,000,000$ & 95.0 & $2,700,000$ & -- & -- & -- & 875,875 \\
\hline 1985 & $1,370,000$ & 39.7 & $28,184,080$ & 112.1 & $2,500,000$ & -- & -- & -- & 559,000 \\
\hline 1986 & $1,492,707$ & 40.1 & $20,873,110$ & 75.8 & $4,200,000$ & -- & -- & $-\cdot$ & 384,800 \\
\hline 1987 & $1,508,927$ & 42.4 & $16,696,374$ & 42.7 & $1,805,000$ & -- & -- & -- & 388,400 \\
\hline 1988 & $1,551,162$ & 44.3 & $17,264,500$ & 48.8 & $3,600,000$ & -- & -- & -- & 389,000 \\
\hline 1989 & $1,452,353$ & 41.5 & $14,418,000$ & 39.9 & $2,914,000$ & -- & -- & -- & $1,492,000$ \\
\hline 1990 & $1,576,000$ & 45.0 & $15,013,500$ & 40.8 & $3,200,000$ & -- & -- & -- & 400,000 \\
\hline 1991 & $1,540,000$ & 39.0 & $14,160,011$ & 45.5 & $3,000,000$ & -- & -- & -- & 462,000 \\
\hline 1992 & $1,531,800$ & 38.3 & $14,599,746$ & 42.2 & $2,900,000$ & -- & -- & -- & 430,000 \\
\hline 1993 & $1,586,545$ & 38.1 & $13,162,402$ & 40.6 & $3,561,324$ & -- & -- & -- & 465,000 \\
\hline 1994 & $1,490,000$ & 36.8 & $13,518,321$ & 41.0 & $3,843,953$ & -- & $-\cdot$ & $-\cdot$ & 459,500 \\
\hline 1995 & $1,640,000$ & 41.3 & $9,847,550$ & 30.9 & $2,811,152$ & -- & -- & -- & 182,500 \\
\hline 1996 & $1,481,000$ & 38.0 & $9,890,463$ & 32.2 & $3,000,045$ & -- & -- & -- & 200,000 \\
\hline 1997 & $1,446,000$ & 38.1 & $13,800,000$ & 51.9 & $3,200,000$ & -- & -- & -- & 217,000 \\
\hline 1998 & $1,339,000$ & 35.2 & $12,363,450$ & 57.3 & $1,636,200$ & -- & -- & -- & 215,000 \\
\hline 1999 & $1,560,000$ & 41.1 & $10,600,000$ & 52.4 & $1,640,000$ & -- & $-\cdot$ & $-\cdot$ & 190,000 \\
\hline 2000 & $1,473,355$ & 38.8 & $10,600,000$ & 49.9 & $5,200,000$ & -- & -- & -- & 203,000 \\
\hline 2001 & $1,537,000$ & 48.1 & $10,360,000$ & 55.2 & $3,091,000$ & -- & -- & -- & 205,000 \\
\hline 2002 & $1,158,000$ & 37.4 & $22,412,000$ & 120.7 & $3,152,000$ & -- & -- & -- & 200,000 \\
\hline 2003 & $1,088,000$ & 38.1 & $11,868,001$ & 64.1 & 861,382 & -- & -- & -- & 175,000 \\
\hline 2004 & $1,450,000$ & 50.8 & $19,576,092$ & 101.5 & $7,312,050$ & -- & -- & -- & $2,732,554$ \\
\hline 2005 & $1,402,174$ & 49.1 & $16,620,009$ & 76.5 & $2,803,172$ & -- & -- & -- & 809,642 \\
\hline 2006 & $1,397,500$ & 48.9 & $13,953,465$ & 63.4 & $2,369,738$ & -- & -- & -- & $1,057,500$ \\
\hline 2007 & $1,273,004$ & 44.6 & $14,163,676$ & 76.1 & $2,211,954$ & -- & -- & -- & $1,085,500$ \\
\hline 2008 & $1,538,000$ & 53.8 & $12,461,685$ & 72.4 & $2,485,820$ & -- & -- & -- & $1,159,502$ \\
\hline 2009 & $1,861,714$ & 65.2 & $7,072,037$ & 41.4 & $1,837,090$ & -- & -- & -- & $3,678,930$ \\
\hline 2010 & $2,061,000$ & 72.1 & $6,977,297$ & 48.0 & 290,852 & -- & -- & -- & $2,303,950$ \\
\hline 2011 & $2,220,000$ & 77.7 & $5,862,851$ & 38.7 & 499,722 & -- & -- & -- & $3,200,000$ \\
\hline 2012 & $2,018,759$ & 70.7 & $7,799,994$ & 52.3 & $1,050,762$ & -- & -- & -- & -- \\
\hline 2013 & $1,600,000$ & 56.0 & $11,622,045$ & 79.6 & 364,632 & -- & -- & -- & $1,900,000$ \\
\hline 2014 & $1,500,000$ & 52.5 & 526,509 & 6.8 & $1,147,869$ & -- & -- & -- & 120,000 \\
\hline 2015 & $1,177,390$ & 41.2 & $5,725,541$ & 17.2 & - - & -- & -- & -- & -- \\
\hline 2016 & 930,987 & 32.6 & $6,123,896$ & 17.3 & -- & -- & -- & $-\cdot$ & -- \\
\hline 2017 & 873,000 & 30.6 & $3,918,110$ & 11.6 & -- & -- & -- & -- & -- \\
\hline Other & -. & -- & -- & -- & $2,300,000^{f}$ & W & 79,000 & W & -- \\
\hline Total & $80,734,311$ & $\$ 1,840.0$ & $1,340,477,236$ & $\$ 3,449.3$ & $153,410,553$ & $\$ 952.5$ & 856,000 & $\$ 11,417.0$ & $\$ 196,782,450$ \\
\hline
\end{tabular}

${ }^{a}$ From published and unpublished State and Federal documents. Where State and Federal figures differ significantly, State figures are used.

bPlease refer to previous editions of this appendix for year-to-year production information for years 1900 to 1979.

cAs of 2015, rock, sand, and gravel are reported as a combined commodity.

dBuilding-stone production figures for 1880-1937 are for the southcentral and interior regions of Alaska only.

eIncludes 2.4 million Ib U3O8 (1955-1971); 505,000 tons gypsum (1905-1926); 286,000 lb WO3 (intermittently, 1916-1980); 94,000 lb asbestos (1942-44); 540,000 Ib graphite (1917-1918 and 1942-1950); and undistributed amounts of zinc, jade, peat, clay, soapstone, miscellaneous gemstones, and other commodities (1880-present).

${ }^{\dagger}$ Marble quarried on Prince of Wales Island, southeastern Alaska (1900-1941).

$\mathrm{m} \$=$ millions of dollars

$\mathrm{t} \$=$ thousands of dollars

- - = not reported

W = withheld 


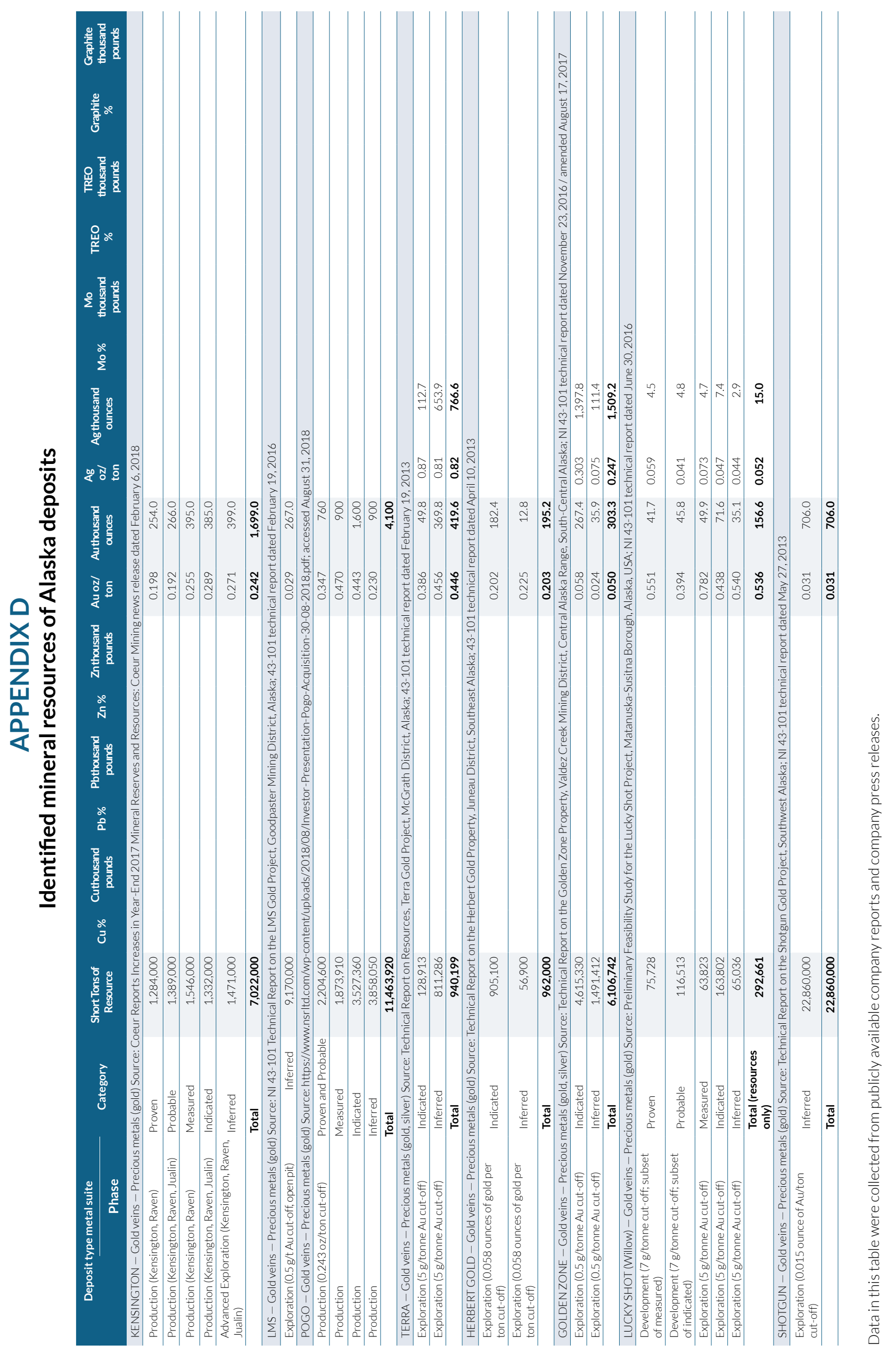




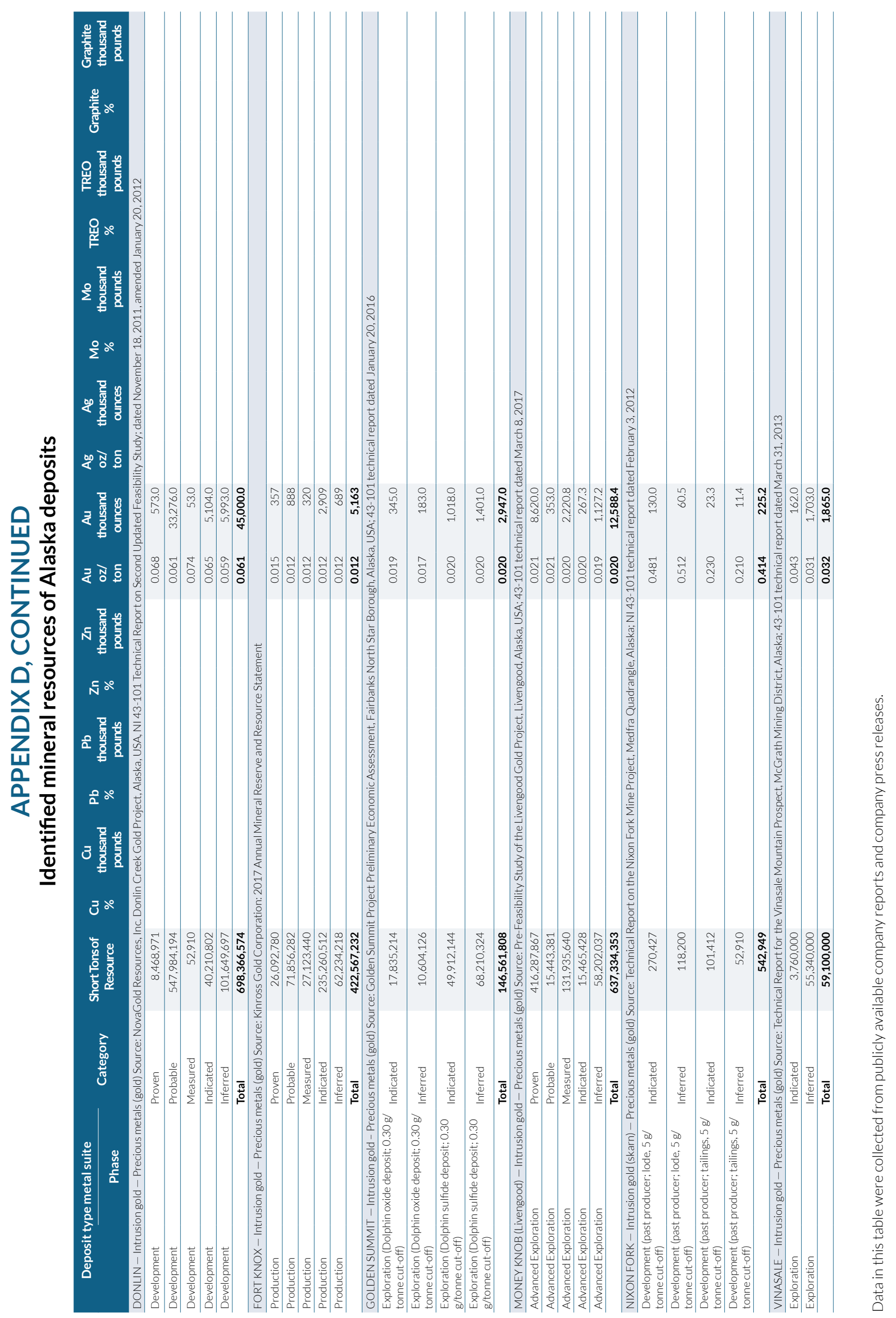




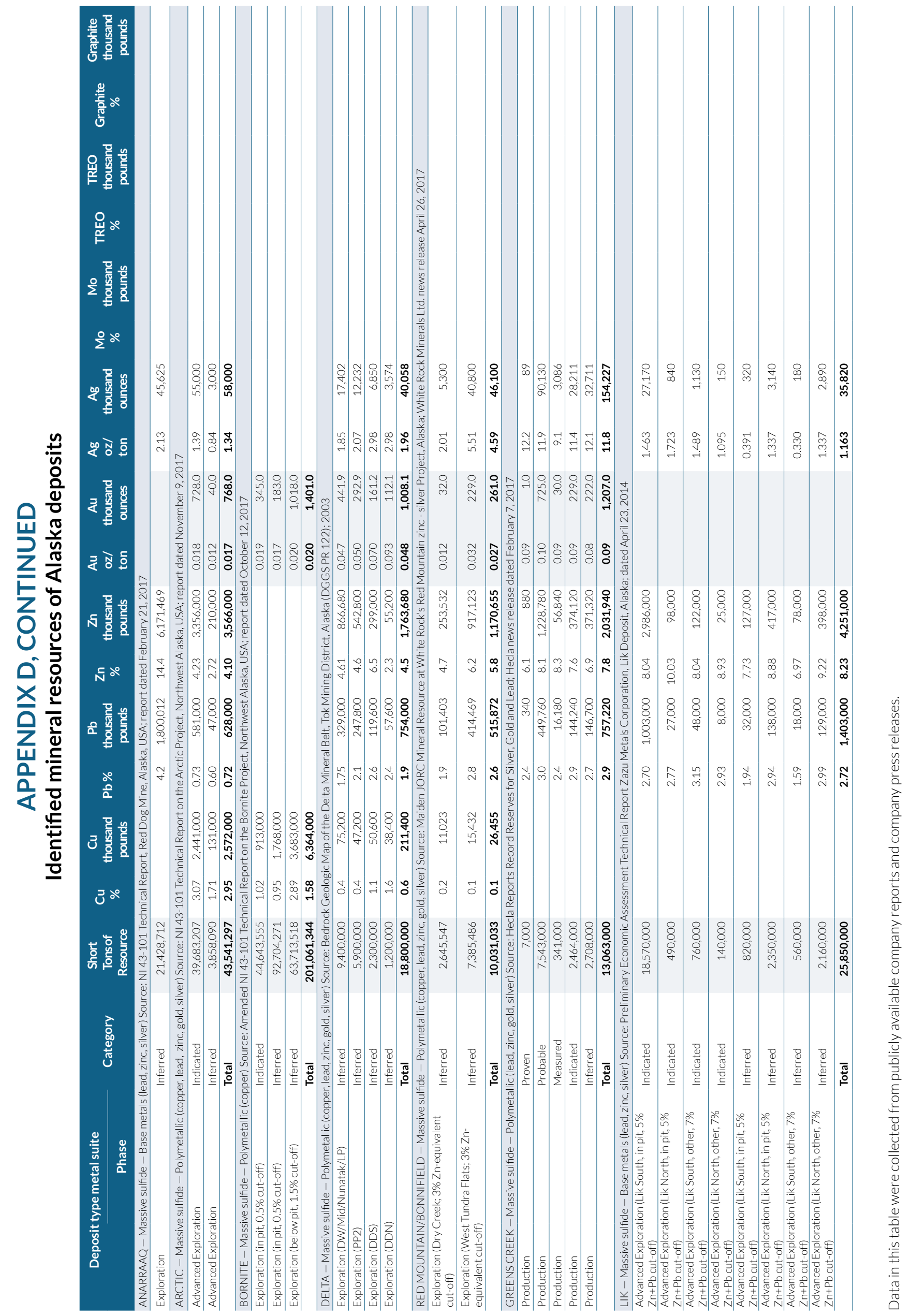




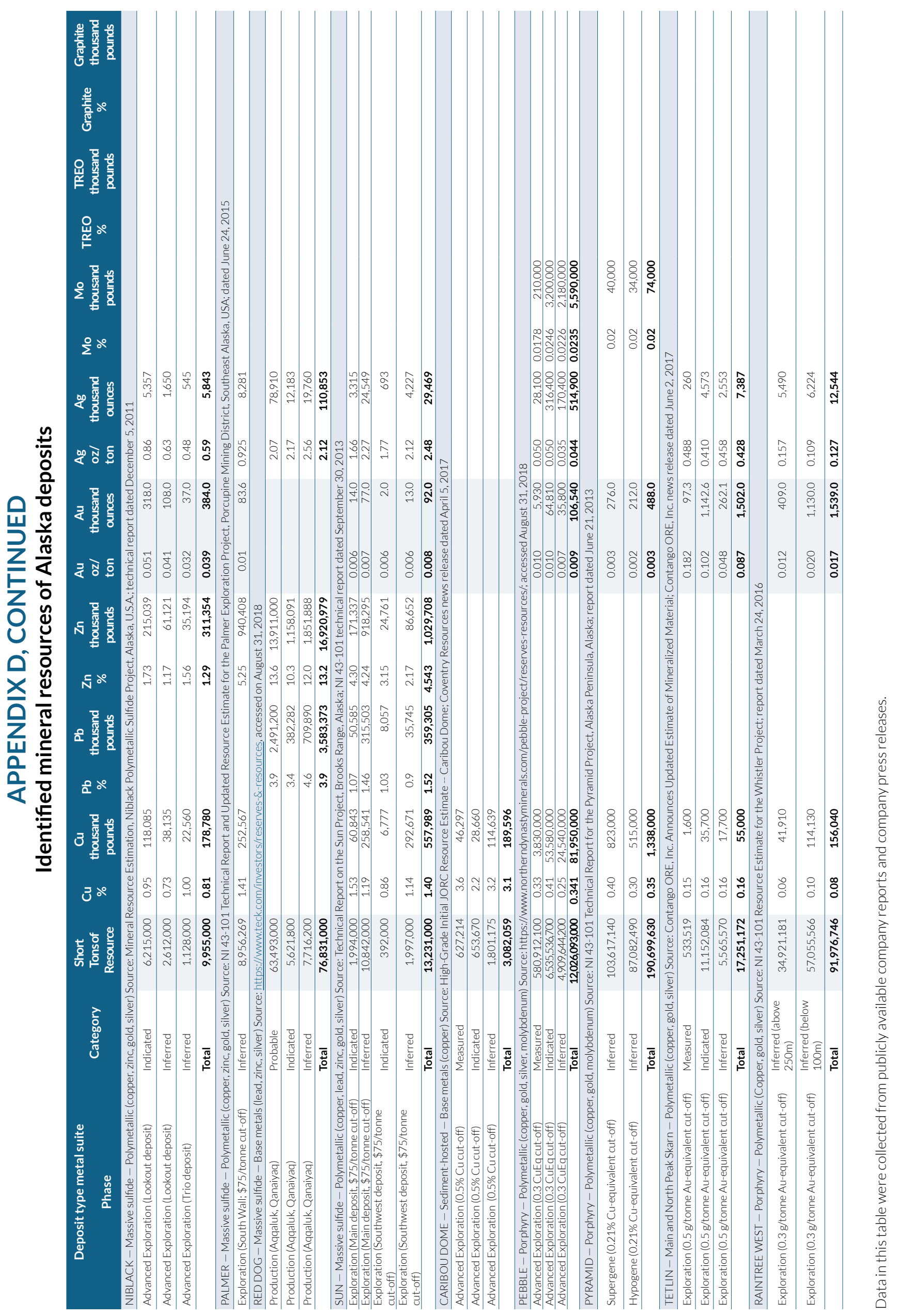




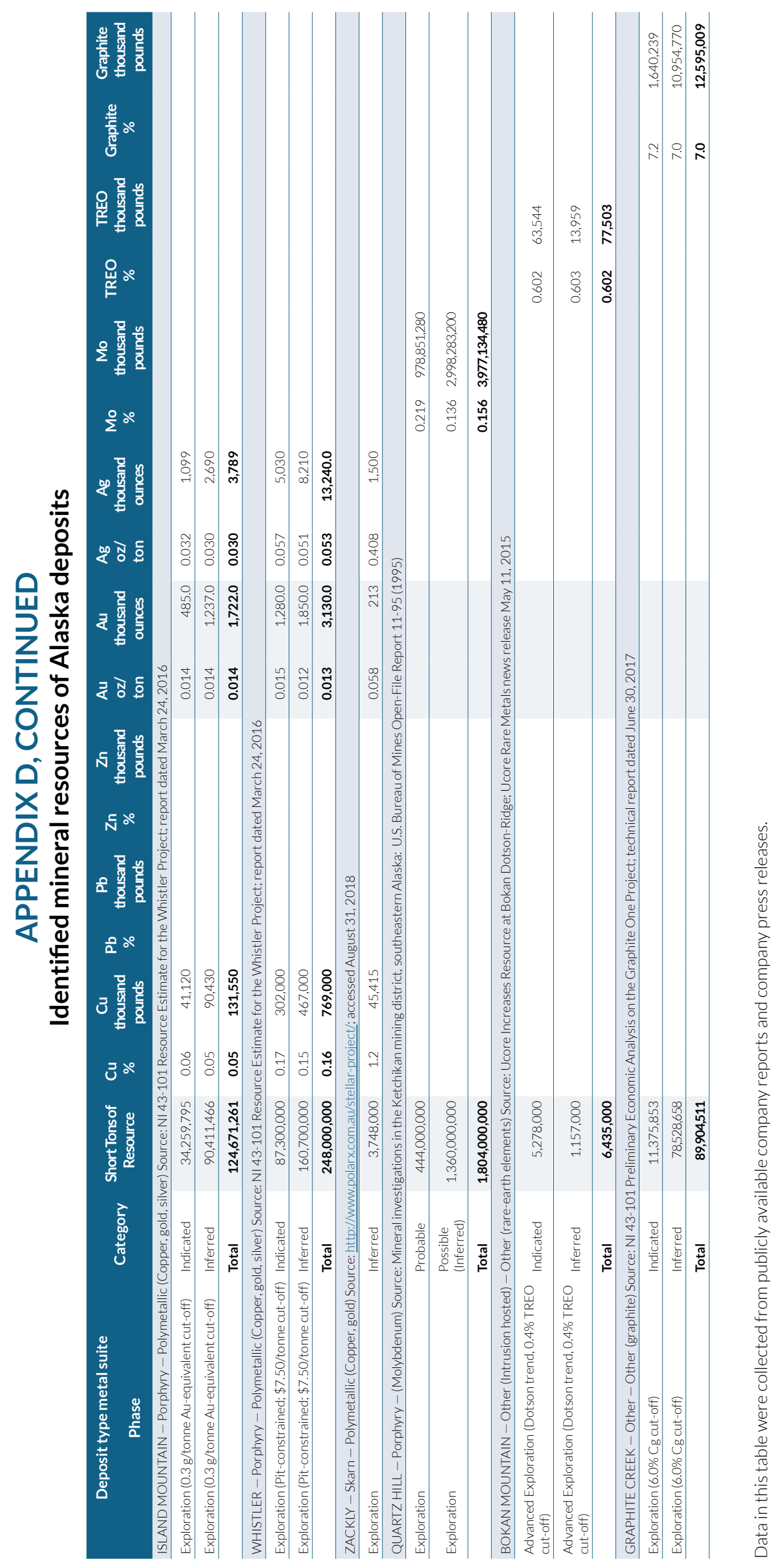




\section{APPENDIXE}

Conversion Chart, U.S. Customary Units/Metric Units

\begin{tabular}{llc}
\multicolumn{1}{c}{ To convert from: } & \multicolumn{1}{c}{ to: } & multiply by: \\
\hline ounces (avoirdupois) & grams & 28.3495 \\
\hline ounces (troy) & grams & 31.1035 \\
\hline pounds & kilograms & 0.4536 \\
\hline short tons & metric tons (tonnes) & 0.9072 \\
\hline grams & ounces (avoirdupois) & 0.03527 \\
\hline grams & ounces (troy) & 0.03215 \\
\hline kilograms & pounds & 2.20462 \\
\hline metric tons (tonnes) & short tons & 1.10231 \\
\hline parts per million $(\mathrm{ppm})$ & parts per billion (ppb) & 1,000 \\
\hline parts per million $(\mathrm{ppm})$ & ounces per ton & 0.0292 \\
\hline parts per million $(\mathrm{ppm})$ & grams/metric tons (tonnes) & 1.00 \\
\hline
\end{tabular}

\begin{tabular}{llc}
\multicolumn{1}{c}{ To convert from: } & \multicolumn{1}{c}{ to: } & multiply by: \\
\hline square miles & \multicolumn{1}{c}{ square kilometers } & 2.59 \\
\hline square miles & acres & 640 \\
\hline acres & square meters & $4,046.86$ \\
\hline acres & hectares & 0.40486 \\
\hline square yards & square meters & 0.836127 \\
\hline square feet & square meters & 0.092903 \\
\hline square inches & square centimeters & 6.4516 \\
\hline square inches & square millimeters & 645.16 \\
\hline square meters & acres & 0.000247105 \\
\hline square kilometers & acres & 247.105 \\
\hline square kilometers & square miles & 0.386102 \\
\hline square meters & square feet & 10.7639 \\
\hline square meters & square yards & 1.19599 \\
\hline hectares & acres & 2.47105 \\
\hline hectares & square meters & 10,000 \\
\hline square centimeters & square inches & 0.155 \\
\hline square millimeters & square inches & 0.00155 \\
\hline
\end{tabular}




\section{APPENDIX E, Continued \\ Conversion Chart, U.S. Customary Units/Metric Units}

\begin{tabular}{llc} 
& \multicolumn{1}{c}{ Length } & \\
To convert from: & \multicolumn{1}{c}{ to: } & multiply by: \\
\hline miles & kilometers & 1.60934 \\
\hline miles & yards & 1,760 \\
\hline miles & meters & $1,609.34$ \\
\hline yards & meters & 0.9144 \\
\hline feet & meters & 0.3048 \\
\hline feet & centimeters & 30.48 \\
\hline feet & millimeters & 304.8 \\
\hline inches & centimeters & 2.54 \\
\hline inches & millimeters & 25.4 \\
\hline kilometers & miles & 0.621371 \\
\hline meters & yards & 1.09361 \\
\hline meters & feet & 3.28084 \\
\hline millimeters & feet & 0.00328 \\
\hline millimeters & inches & 0.03937 \\
\hline centimeters & inches & 0.3937 \\
\hline
\end{tabular}

\section{Volume}

To convert from:

cubic yards

cubic feet

cubic inches

cubic meters

cubic meters

cubic centimeters

gallons (U.S.)

liters

milliliters

ounces (fluid)

to:

cubic meters

cubic meters

cubic centimeter

cubic yards

cubic feet

cubic inches

liters

gallons (U.S.)

ounces (fluid)

milliliters

\section{Temperature}

To convert from:

to:

do this:

degrees Fahrenheit

degrees Celsius

degrees Fahrenheit

degrees Celsius

degrees Fahrenheit

multiply by:

0.764555

0.0283168

16.3871

1.30795

35.3147

0.0610237

3.78541

0.264172

0.033814

29.5735
subtract 32 , multiply by 5 , divide by 9

multiply by 9 , divide by 5 , add 32 


\begin{tabular}{|c|c|c|c|c|}
\hline \multirow{2}{*}{\multicolumn{2}{|c|}{ Mining districts ${ }^{a}$}} & \multicolumn{3}{|c|}{ Production (in refined troy ounces) } \\
\hline & & Total & Placer & Lode \\
\hline 1 & Lisburne district & 0 & 0 & 0 \\
\hline 2 & Noatak district & 7,800 & 7,800 & 0 \\
\hline 3 & Wainwright district & 0 & 0 & 0 \\
\hline 4 & Barrow district & 0 & 0 & 0 \\
\hline 5 & Colville district & 0 & 0 & 0 \\
\hline 6 & Canning district & 0 & 0 & 0 \\
\hline 7 & Sheenjek district & 0 & 0 & 0 \\
\hline 8 & Chandalar district & 70,278 & 52,878 & 17,400 \\
\hline 9 & Koyukuk district & 378,075 & 378,075 & 0 \\
\hline 10 & Shungnak district & 15,000 & 15,000 & 0 \\
\hline 11 & $\begin{array}{l}\text { Kiana \& Selawik } \\
\text { districts }\end{array}$ & 40,607 & 40,607 & 0 \\
\hline 12 & $\begin{array}{l}\text { Fairhaven district } \\
\text { (Candle subdistrict) }\end{array}$ & 254,265 & 254,265 & 0 \\
\hline 13 & $\begin{array}{l}\text { Fairhaven district } \\
\text { (Inmachuk } \\
\text { subdistrict) }\end{array}$ & 349,975 & 349,975 & 0 \\
\hline 14 & Serpentine district & 4,536 & 4,536 & 0 \\
\hline 15 & $\begin{array}{l}\text { Port Clarence } \\
\text { district }\end{array}$ & 42,358 & 42,358 & 0 \\
\hline 16 & Kougarok district & 191,712 & 191,712 & 0 \\
\hline 17 & $\begin{array}{l}\text { Nome (Cape Nome) } \\
\text { district }\end{array}$ & $5,043,465$ & $5,043,465$ & 0 \\
\hline 18 & Council district & $1,047,042$ & $1,020,042$ & 27,000 \\
\hline 19 & Koyuk district & 84,462 & 84,462 & 0 \\
\hline 20 & Hughes district & 403,671 & 403,671 & 0 \\
\hline 21 & Kaiyuh district & 149,703 & 5,400 & 144,303 \\
\hline 22 & Anvik district & 7 & 7 & 0 \\
\hline 23 & Marshall district & 124,506 & 124,506 & 0 \\
\hline 24 & Bethel district & 42,953 & 42,953 & 0 \\
\hline 25 & $\begin{array}{l}\text { Goodnews Bay } \\
\text { district }\end{array}$ & 31,202 & 31,202 & 0 \\
\hline 26 & Aniak district & 613,407 & 613,407 & 0 \\
\hline 27 & Iditarod district & $1,565,226$ & $1,562,296$ & 2,930 \\
\hline 28 & McGrath district & 364,672 & 133,307 & 231,365 \\
\hline 29 & Innoko district & 757,219 & 757,063 & 156 \\
\hline 30 & Ruby district & 478,023 & 478,023 & 0 \\
\hline 31 & Kantishna district & 99,307 & 91,401 & 7,906 \\
\hline 32 & Hot Springs district & 604,926 & 604,926 & 0 \\
\hline 33 & Melozitna district & 14,630 & 14,630 & 0 \\
\hline 34 & Rampart district & 204,845 & 204,845 & 0 \\
\hline 35 & Tolovana district & 547,556 & 547,556 & 0 \\
\hline 36 & Yukon Flats district & 0 & 0 & 0 \\
\hline 37 & Circle district & $1,125,341$ & $1,125,341$ & 0 \\
\hline 38 & Black district & 2 & 2 & 0 \\
\hline 39 & Eagle district & 52,166 & 52,166 & 0 \\
\hline 40 & Fortymile district & 602,758 & 602,758 & 0 \\
\hline 41 & Chisana district & 144,521 & 78,021 & 66,500 \\
\hline 42 & Tok district & 288 & 288 & 0 \\
\hline 43 & Goodpaster district & $3,640,745$ & 2,051 & $3,638,694$ \\
\hline 44 & Fairbanks district & $16,195,562$ & $8,282,595$ & $7,912,967$ \\
\hline
\end{tabular}

\begin{tabular}{|c|c|c|c|c|}
\hline \multirow{2}{*}{\multicolumn{2}{|c|}{ Mining districts ${ }^{\mathrm{a}}$}} & \multicolumn{3}{|c|}{ Production (in refined troy ounces) } \\
\hline & & Total & Placer & Lode \\
\hline 45 & Bonnifield district & 108,983 & 102,283 & 6,700 \\
\hline 46 & $\begin{array}{l}\text { Richardson } \\
\text { subdistrict of } \\
\text { Fairbanks district }\end{array}$ & 121,828 & 119,528 & 2,300 \\
\hline 47 & Delta River district & 11,732 & 11,732 & 0 \\
\hline 48 & Chistochina district & 186,604 & 186,604 & 0 \\
\hline 49 & $\begin{array}{l}\text { Valdez Creek } \\
\text { district }\end{array}$ & 533,167 & 531,586 & 1,581 \\
\hline 50 & Yentna district & 204,980 & 204,980 & 0 \\
\hline 51 & Redoubt district & 105 & 105 & 0 \\
\hline 52 & Bristol Bay Region & 1,570 & 1,570 & 0 \\
\hline 53 & $\begin{array}{l}\text { Kodiak district } \\
\text { (53b)-Alaska } \\
\text { Peninsula Region } \\
\text { (53a) }\end{array}$ & 112,409 & 4,809 & 107,600 \\
\hline 54 & Homer district & 17 & 17 & 0 \\
\hline 55 & $\begin{array}{l}\text { Hope \& Seward } \\
\text { districts }\end{array}$ & 135,252 & 70,252 & 65,000 \\
\hline 56 & Anchorage district ${ }^{c}$ & 460 & 460 & 0 \\
\hline 57 & $\begin{array}{l}\text { Willow Creek } \\
\text { district }\end{array}$ & 667,841 & 58,841 & 609,000 \\
\hline 58 & $\begin{array}{l}\text { Prince William } \\
\text { Sound district }\end{array}$ & 137,802 & 102 & 137,700 \\
\hline 59 & Nelchina district & 15,016 & 15,016 & 0 \\
\hline 60 & Nizina district & 148,500 & 148,500 & 0 \\
\hline 61 & Yakataga district & 18,041 & 18,041 & 0 \\
\hline 62 & Yakutat district ${ }^{d}$ & 13,200 & 2,200 & 11,000 \\
\hline 63 & $\begin{array}{l}\text { Juneau district } \\
\text { (partial) }\end{array}$ & 82,540 & 82,540 & 0 \\
\hline 64 & $\begin{array}{l}\text { Juneau (64a) \& } \\
\text { Admiralty (64b) } \\
\text { districts }\end{array}$ & $10,252,593$ & 82,390 & $10,170,203$ \\
\hline 65 & Chichagof district & 770,000 & 0 & 770,000 \\
\hline 66 & Petersburg district & 15,000 & 15,000 & 0 \\
\hline 67 & Kupreanof district & 0 & 0 & 0 \\
\hline 68 & Hyder district & 219 & 219 & 0 \\
\hline 69 & Ketchikan district & 62,002 & 4,002 & 58,000 \\
\hline 70 & Bering Sea Region & 0 & 0 & 0 \\
\hline 71 & $\begin{array}{l}\text { Aleutian Islands } \\
\text { Region }\end{array}$ & 0 & 0 & 0 \\
\hline & $\begin{array}{l}\text { Unknown } \\
\text { (undistributed)e }\end{array}$ & 160,546 & 160,546 & 0 \\
\hline & $\begin{array}{r}\text { TOTAL (refined Troy } \\
\text { ounces) }\end{array}$ & $49,053,217$ & $25,064,912$ & $23,988,305$ \\
\hline
\end{tabular}

aMining district names and boundaries revised slightly from those defined by Ransome and Kerns (1954) and Cobb (1973). Sources of data: U.S. Geological Survey, U.S. Bureau of Mines, and Alaska Territorial Department of Mines records 1880-1930; U.S. Mint records 19301969; State of Alaska production records 1970-2017. Entries of "0" generally mean no specific records are available.

${ }^{b}$ Not included in total for Fairbanks district.

cMost placer gold production included in Willow Creek district.

Includes lode production from Glacier Bay area and placer production from Lituya Bay area.

eProduction that cannot be credited to individual districts due to lack of specific records or for reasons of confidentiality. Beginning in 2015, placer production is not compiled for individual mining districts, but is instead included in the 'Unknown' category. 


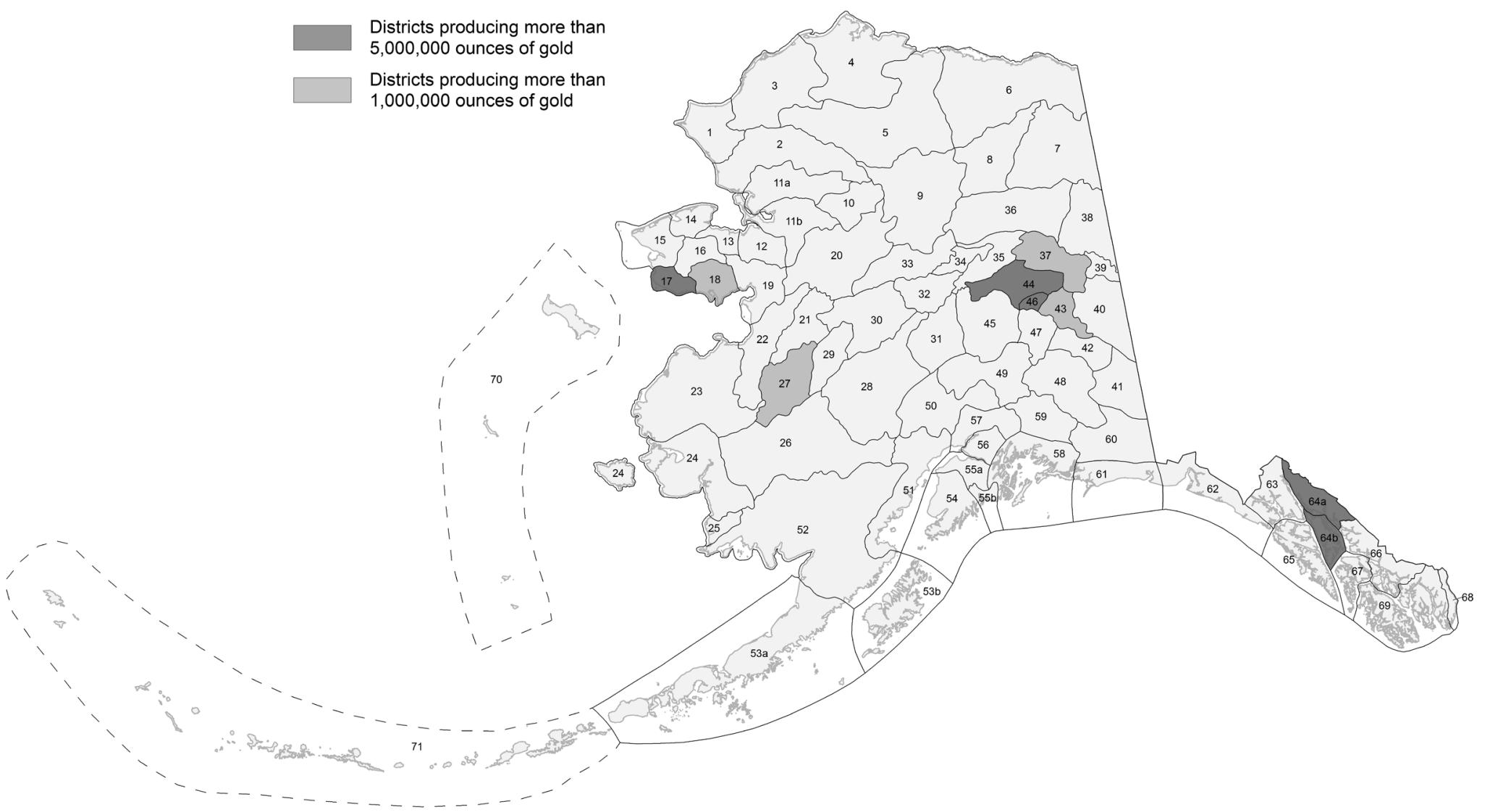

Back cover. In 2017 Avidian Gold Alaska Inc.'s surface sampling and mapping program around the Golden Zone property, located midway between Anchorage and Fairbanks, confirmed metal anomalies from previous work and resulted in new mineralized targets. Photo courtesy of Tom Setterfield, Avidian Gold Alaska Inc. 
